Flight and Integration Causes of Mass Exodus from Ethiopia and Problems of Integration in the Sudan

\author{
Mekuria Bulcha
}

Scandinavian Institute of African Studies, Uppsala 
Flight and Integration 



\title{
Flight and Integration
}

Causes of Mass Exodus from Ethiopia and Problems of Integration in the Sudan

\author{
Mekuria Bulcha
}

Scandinavian Institute of African Studies, Uppsala 
( 1988 Mekuria Bulcha and Nordiska afrikainstitutet ISBN 91-7106-279-3

Printed in Sweden by

Motala Grafiska, Motala 1988 


\section{Acknowledgements}

In the course of writing this book I have become indebted to many people and several institutions in Sweden and the Sudan. I owe the deepest gratitude to Professor Ulf Himmelstrand without whose generous support and guidance this work could not have been completed. My sincere thanks also go to Docent Pablo Suarez who read my manuscript and gave me useful criticism and advice. I should also acknowledge my debt to Dr. Michael Ståhl, Dr. Peter Nobel and Dr. Gaim Kibreab for their support and intellectual stimulation. I would like to express my appreciation for the assistance I received from the Scandinavian Institute of African Studies (SIAS). Karl Eric Ericson and Ingrid Dahlquist of the SIAS have been of the utmost help. I thank them sincerely.

I am grateful to the staff of the Office of the Sudanese Commissioner for Refugees in Khartoum and Gedaref. My sincere thanks go also to the United Nations High Commissioner for Refugees (UNHCR) and the Sudanese Economic and Social Research Council (ESRC) in Khartoum. In Gedaref, I thank Lars Jonsson of the UNHCR, the staff of the Sudanese Council of Churches (SCC) and the International Rescue Committee (IRC). I received valuable support from all of them. In Damazin, Kurmuk and Yabus I am most grateful to the staff of the Oromo Relief Association (ORA) without whose generous support my field work in those places would have been impossible. I am grateful to the Sudanese Security Police in Damazin and Kurmuk for their assistance.

I am also indebted to my field assistants Gebrezghi Isaias, Zerai Woldai, Humedin Suleiman, Asmerom Berhe and Ghebregziabher Seyoum with whom I shared the hardships of the fieldwork. I thank my friend Wendy Duncan of the Institute of International Education at the University of Stockholm for her editorial work, Gladys Golborne of the University of Uppsala for the assistance she accorded me in processing the data and Sture Balgård for drawing the maps I used in this work. Fekadu Megarsa typed the first drafts of Chapters 2 and 3. Paul Brady and Mohammed Farah of the Department of Sociology at the University of Uppsala gave me some of the most stimulating criticisms and views. I thank them all.

Without the financial assistance of the Swedish Agency for Research Co-operation with Developing Countries (SAREC) I could have not carried out this work sucessfully. I am grateful to SAREC. I also thank the University of Uppsala and the Swedish Institute for the scholarship grants I received from them for several years.

Finally I give my thanks to my dear Maazash who spent countless evenings, weekends and holidays patiently typing and retyping the various drafts of this work. Her contribution and encouragement helped me most to complete the book.

The book is dedicated to the subjects of the study - the refugees themselves. 


\section{Abbrevations}

$\begin{array}{ll}\text { ALF } & \text { Afar Liberation Front } \\ \text { AMC } & \text { Agricultural Marketing Corporation } \\ \text { AETU } & \text { All-Ethiopian Trade Union } \\ \text { ASS } & \text { The Anti-Slavery Society } \\ \text { COPWE } & \text { Commission for the Formation of the Party of the Working } \\ & \text { People of Ethiopia } \\ \text { COR } & \text { Office of the Commissioner for Refugees } \\ \text { EDU } & \text { Ethiopian Democratic Union } \\ \text { ELF } & \text { Eritrean Liberation Front } \\ \text { EPLF } & \text { Eritrean People's Liberation Front } \\ \text { EPRP } & \text { Ethiopian People's Revolutionary Party } \\ \text { ERA } & \text { Eritrean Relief Association } \\ \text { ESRC } & \text { Economic and Social Research Council } \\ \text { ICARA } & \text { International Conference for Assistance to Refugees in Africa } \\ \text { ILO } & \text { International Labour Office } \\ \text { IMF } & \text { International Monetary Fund } \\ \text { IRC } & \text { International Rescue Committee } \\ \text { MEISON } & \text { All-Ethiopian Socialist Movement } \\ \text { NGO } & \text { Non-Governmental Organization } \\ \text { NRC } & \text { National Research Council } \\ \text { OAU } & \text { Organization for African Unity } \\ \text { OLF } & \text { Oromo Liberation Front } \\ \text { ORA } & \text { Oromo Relief Association } \\ \text { PMAC } & \text { Provisional Military Administrative Council } \\ \text { POMOA } & \text { Provisional Officefor Mass Organizational Affairs } \\ \text { RRC } & \text { Relief and Rehabilitation Commission } \\ \text { REST } & \text { Relief Society of Tigray } \\ \text { SCC } & \text { Sudan Council of Churches } \\ \text { SI } & \text { Survival International } \\ \text { SIDA } & \text { Swedish International Development Authority } \\ \text { TPLF } & \text { Tigray People's Liberation Front } \\ \text { UN } & \text { United Nations } \\ \text { UNHCR } & \text { United Nations High Commissioner for Refugees } \\ \text { WSLF } & \text { West Somali Liberation Front } \\ & \end{array}$




\section{Contents}

Acknowledgements 5

List of Abbreviations 6

List of Tables 9

Figures and Maps 11

\section{PART' I: THE GENERAL BACKGROUND}

\section{Chapter 1. General Introduction}

The Study 15

Refugees in Africa: The Problem 18

Local and International Responses to the African Refugee Problem 21

The Setting of the Present Study 25

Chapter 2. The Mass Exodus from Ethiopia: Historical Background

Introduction 32

The Conquest and Colonization of the Oromo, Sidama and Other Adjacent Peoples (1876-1909) 33

Basic Features of Abyssinian Feudal Colonialism 39

Resistance and Rebellions 50

Conclusions 60

Chapter 3. The Ethiopian Revolution of 1974

Introduction 62

The Contention for State Power 63

The Question of Nationalities 67

Conclusion 72

\section{PART II: THE FLIGHT}

Chapter 4. The Conceptual and Methodological Framework

Introduction 77

The Paucity of Theoretical Literature 77

The Conceptual Framework used in this Study 78

Integration in the Socio-Economic Structures of the Host Society 84

Research Methodology 91

Chapter 5. Immediate Subjective and Objective Causes of Mass Flight from Ethiopia

Introduction 98

Subjective Definitions of Reasons for Flight and Prevalent Objective Conditions 100

Armed Conflicts 106 
Military Conscription 109

Poverty as a Cause of Flight 110

Large Scale Implemention of Forced Labour as Direct Cause of Flight 112

Relocation: A Contributory Factor to Refugee Flows 115

Current Mass Relocation in Ethiopia 116

Responses to Relocation 120

Villagization and Displacement: A Critical Assessment 124

Types of Respondents and Forms of Displacement 126

Chapter 6. Flight Dynamics and Intervening Obstacles

Introduction 130

The Decision to Flee 130

Intervening Problems and Hardships 138

Arrival in the Host Environment 140

Conclusion 144

\section{PART III: THE DIMENSIONS OF INTEGRATION}

\section{Chapter 7. The Economic Dimension of Integration}

Introduction 149

Conditions and Limitations 149

A Portrait of the Sample Population 150

Employment: First Step Towards Integration 156

Meeting Basic Needs and Achieving Self-Sufficiency 159

Income Distributions of Sample Population 162

Survival Strategies 168

Conclusions 172

Chapter 8. The Social Dimension of Integration

Introduction 174

Social Interaction and Informal Relationships Between Respondents

and Hosts 176

Intermarriage Between Refugees and Sudanese 181

Voluntary Organizations 183

Social Conflicts and Integration 188

Conflict in the Refugee Situation 189

Summary 196

Chapter 9. Cultural and Psychological Aspects of Adjustment and Integration Introduction 198

Causes of Refugee Maladjustment 199

Acculturation: Indicator of Adjustment or a 'Passing' Mechanism? 202

Education and Acculturation 205

Insecurity, Anxiety and Guilt 207

Operative Variables in the Generation of Fear and Anxiety 210

Preflight Variables: Causes of Flight 210

Insecurity and Post-Flight Variables 212

Summary and Conclusions 217 
PART IV

Chapter 10. Summary and Policy Implications

Notes 236

Bibliography 241

Appendix 252

\section{Tables}

Chapter 1

Table 1.1

Table 1.2 Refugee influx into the Sudan by year and country of origin 28

Chapter 2

Table 2.1 The ethnic backgrounds of the populations of the major towns in the conquered regions of the south 45

Chapter 5

Table 5.1

Table 5.2

Percentage distribution of respondents by date of arrival in the Sudan 98

Chapter 6

Table 6.1a Distribution of respondents by information 130

Table 6.1b Distribution of respondents by flight plan 130

Table 6.2 Duration of flight by sample site 135

Table 6.3 Flight days by type of refugee 136

Table 6.4 Means of transport by type of refugee 136

Table 6.5 Educational background by place of settlement in country of asylum 137

Table 6.6 Major problems encountered during flight 139

Table 6.7 Types of hardship encountered by respondents during flight by settlement site 139

Table 6.8 Type of problems encountered by respondents on arrival in host country 140

Table 6.9 Solution of initial problems by settlement sites 142

Table 6.10 Solution of initial problems by type of settlement 143

Table 6.11 Source of assistance received on arrival by type of settlement 144

Chapter 7

Table 7.1

Table 7.2

Table 7.3

Table $7.4 \mathrm{a}$

Table $7.4 \mathrm{~b}$

Table $7.5 \mathrm{a}$

Table $7.5 b$

Table 7.6 Respondents' level of education by type of settlement 154

Table 7.7 Occupational status of respondents before and after flight 155

Table 7.8 Length of employment 157

Table 7.9 Length of employment by type of refugees and type of settlement

Table 7.10 Length of employment by level of education 158

Table 7.11 Estimated income levels for existence minimum and self-sufficient households (1982-83) 160

Table 7.12 Distribution of respondents by sufficiency of income for existence minimum 162 
Table 7.13 Distribution of annual income by settlement site 162

Table 7.14 Length of residence by annual income 163

Table 7.15 Income distribution by sex of household head 165

Table 7.16 Respondents by main occupation and average annual income 165

Table 7.17 Income distribution by type of refugee and settlement 167

Table 7.18 Source of supplementary income in times of shortage or unemployment by type of settlement and refugees 169

Table 7.19 Distribution of households by percentage of total income spent on basic needs 171

Chapter 8

Table 8.1 Frequency of informal personal relations between respondents and

Sudanese by sample sites 176

Table 8.2 Knowledge of Arabic by informal personal relations between respondents and Sudanese 177

Table 8.3a Informal personal relations by gender of respondent 177

Table 8.3b Knowledge of Arabic by gender 177

Table 8.4 Distribution of respondents having informal personal relations with Sudanese by type of settlement 178

Table 8.5 Distribution of respondents having informal personal relations with Sudanese by refugee category (urban/rural) 179

Table 8.6 Respondent membership of voluntary organizations by sample sites 184

Table 8.7 Membership of voluntary organizations by type of organization 185

Table 8.8 Membership of voluntary organizations by type of settlement 186

Table 8.9 Distribution of respondents reporting host-refugee conflicts by sample sites 190

Table 8.10a Host-refugee conflicts by type of settlement 191

Table 8.10b Host-refugee conflicts by refugee category 191

Table 8.11 Respondents reporting refugee-refugee conflicts by sample sites 194

Table 8.12 Respondents reporting conflicts among refugees by cause of conflicts 194

Table 8.13 Respondents reporting conflicts among refugees by type of settlement 195

Chapter 9

Table 9.1

Table 9.2

Table 9.3

Table 9.4

Table 9.5

Table 9.6

Table 9.7

Table 9.8

Table 9.9

Table 9.10

Table 9.11

Table 9.12

Table 9.13

Adjustment (respondent self-evaluation) by sample sites 200

Reasons for maladjustment by sample site 201

Reasons for making changes 203

Child/ren's school attendance 206

Types of schools attended by refugee children 206

Reasons given by refugee parents for not sending their children to school

Fear by sample site 208

Type of fear reported by respondents by settlement site 209

Frequency of respondents reporting fear by reason for flight 211

Fear by economic performance in the host country 212

Fear by type of settlement and of refugees 213

Fear by length of residence in the Sudan 214

Fear by sex 215 


\section{Figures}

\section{Chapter 4}

Figure 1 Refugee categories: A conceptual model $\mathbf{8 1}$

Figure 2 Schematic representations of variables in the refugee integration process

Figure 3 Type of settlements, refugees and major sources of subsistence $\mathbf{9 3}$

\section{Maps}

Chapter 2

Map 1 The conquests of Menelik II 34

Map 2 Land tenure systems prior to the land reform of 197543

Map 3 Major peoples and languages in Ethiopia 48

\section{Chapter 4}

Map 4 Refugee affected areas in Eastern Sudan and sites covered in this study $\mathbf{9 3}$ Map 5 Tawawa Refugee Settlement 94

\section{Chapter 5}

Map 6 Areas of conflict between nationalist movements and government forces $\mathbf{1 0 7}$ Map 7 Areas affected by resettlement up to $1986 \mathbf{1 2 0}$ 



\section{PART I \\ THEGENERAL BACKGROUND}





\section{Chapter I \\ General Introduction}

\section{The Study}

This is a study about involuntary migration. It deals with the largest forced mass movement from one country in modern African history, namely the current exodus from Ethiopia.

In the past two decades the Horn of Africa, with Ethiopia as an epicentre, has experienced an unprecented wave of refugee flows, resulting in large concentrations of displaced persons. By 1980-81 estimates of homeless persons in the region ranged between 5.5 to 6 million. More than one third of these people were located outside their countries of origin (Horn of Africa, Vol. 1, 1981:6) and were refugees in the original sense of the word. Nearly all of these displaced persons and refugees were from Ethiopia.

Today there are nearly two million people who have fled from Ethiopia and live in other countries. Consequently, the number of refugees originating from Ethiopia is second only to those from Afghanistan. The two neighbouring countries of Somalia and Sudan are together sheltering about 90 per cent of these involuntary migrants. Outside the Horn of Africa the largest concentration of refugees from Ethiopia is perhaps found in the Middle East. According to our own estimates, there are not less than 60,000 Ethiopian exiles in Europe with the main concentrations in countries such as Italy, West Germany, England and Sweden. There are almost as many refugees in North America, with the majority living in the United States. Every year there are a few thousand new arrivals. Small pockets of skilled and educated Ethiopian exiles also live scattered in several other countries all over the world.

It is difficult to obtain reliable estimates of internal displacement within Ethiopia itself. Social conflicts and natural disasters have uprooted and displaced millions of peasants, agro-pastoralists and urban dwellers over the last ten years. This is currently being reinforced by forcible relocation which the military government is carrying out on a large scale. Over one million people have been transferred from northern Ethiopia to the south mainly between 1979 and 1986. Around seven million peasants have been relocated in the south of the country. These forcible relocation operations have become one of the major factors behind flight across international borders. They also cause internal displacement to areas beyond the control of the Ethiopian military forces. Together with the internal displacement and relocation, mass flight is posing problems that have far-reaching consequences for the country, the region, and above all for the displaced individuals, families and groups. 


\section{Purpose}

This study arose out of a concern with the critical problems facing refugees in the Horn of Africa. It ultimately became a sociological enquiry into the causes and consequences of the dislocation of hundreds of thousands of people of different national background and from different parts of Ethiopia who have sought asylum in the Republic of the Sudan. Unlike most other studies which analyze the causes of contemporary refugee flows, the focus here is on both the history and the present conditions in the society of origin.

The study has four main aims. Firstly, it aims to identify the root causes of the refugee-producing conflicts in Ethiopia. This requires insight into the history of the peoples in question. The furthest logical distance we could go in historical time to locate the roots of the refugee-producing conflicts is the period of the formation of Ethiopia as an empire at the turn of the century. Most of the current conflicts have direct connections with that period and the process that brought a number of independent peoples under Ethiopian (Abyssinian) rule. Hence, we will describe and analyze the evolution of the multi-national state in order to illuminate the relations - and consequently the locations of the conflicts- between the central state and the subjugated nationalities in the political and socio-cultural peripheries.

The second aim of the study is to describe the ramifications of the current refugee-producing problems in Ethicpia. Here the aim is to transcend the commonly held and rather simplistic assumption that Ethiopian refugee flows are the results of natural catastrophes and/or "ethnic" conflicts. We will examine subjective motives and explore objective conditions. The subjective motives are the reasons given by refugees themselves for their departure from home. They are the definitions of the situation as experienced or felt by them. The objective conditions concern the status quo (social, economic and political) prevailing at the time of flight. The focus is primarily upon those aspects of the objective conditions which were identified by respondents as a cause for flight.

A brief examination of the process of transition from a citizen to refugee is the third objective of the study. Here we shall focus on those factors which in addition to change in the socio-political environment, are assumed to be determinant in the flight decision making process. Three sets of variables, socio-psychological,socialstructural and physical, will briefly be examined in this connection.

The fourth, and the major, objective of this study is to explore the problems which respondents encounter in the process of their integration into Sudanese society. Here societal integration is conceived as a multi-dimensional phenomenon. Consequently, our analytical model of the process includes four inter-related and interdependent spheres: the economic, the social, the cultural, and the socio-psychological. The aim is to identify and analyze variables that influence integration in each dimension. Comparisons between different refugee categories are made using these variables as indices. The viability of the various types of settlements with regard to economic self-sufficiency and socio-cultural integration are described, analyzed and compared. 


\section{Structure}

This book is divided into four parts. Part I contains an introduction and a brief account of the socio-historical and political events preceding the contemporary refugee exoduses from Ethiopia. Part II sets out the conceptual and methodological framework of the study. In addition, this part deals also with the immediate subjective motives and objective conditions of refugee flows from Ethiopia to the Sudan. Part III covers the various aspects of respondent integration in the host society. Part IV provides a summary and policy implications.

The book has 10 chapters. The rest of this introductory chapter contains a short review of the history of involuntary population movements in Africa, local and international responses to the African refugee problem during the past three decades, the setting (Sudan) in which the present study is conducted, and the Sudanese experience of refugee influxes.

Chapter 2 is a brief sketch of the historical background to the current refugee exoduses from Ethiopia. Since the main focus in the chapter is on conflict generating factors, the colonial structure of dominance and the mode of exploitation imposed on the peoples incorporated in the Ethiopian empire through conquest and annexation are examined. The main conflicts in the life-span of the empire are identified, with the view of establishing their links with the present-day confrontations between the military government and the non-Amhara liberation fronts.

Chapter $\mathbf{3}$ is the more immediate aspect of the historical leitmotif against which the refugee problem in this volume is discussed. It deals very briefly with the Ethiopian revolution and the political power relations which evolved in Ethiopia in its aftermath. The focus in the chapter is on the factors that led to the polarization between the central military government, the Dergue, and the liberation fronts in the peripheries.

Chapter 4 provides the theoretical and methodological framework on which the study is based. It defines the main concepts used in the analysis, and identifies refugee typologies and forms of their displacement. Chapter 5 discusses the motives of respondents and the prevailing objective conditions in the country of origin which generate refugee exoduses. The focus in Chapter 6 is on the transition (flight) itself. It attempts to delineate variables which, in addition to threatening changes in the socio-political environment, may influence individual and/or group decisions to uproot and flee. The chapter also provides a description of the intervening obstacles encountered during flight. The patterns of settlement which different refugee categories follow on their arrival in the country of asylum are discussed here.

Chapters 7, 8 and 9 deal with the various dimensions of integration in the host society. Chapter 7 is concerned with the economic aspects. It discusses, inter alia, the means used by respondents to earn their livelihood and their past and present occupational profiles. Since economic self-sufficiency and self-reliance are central concepts in our analysis of economic integration, various refugee and host-related factors which determine self-sufficiency are identified and analyzed.

The focus in Chapter 8 is social integration. Social interaction and social conflict are the key concepts in the chapter. The respondents' integration into the networks of primary and secondary social relationships with their hosts and within their own communities are treated. The relationships between settlement pattern and social 
integration are identified and analyzed. Chapter 9 deals with the cultural and socio-psychological dimension of integration in the host environment. Chapter 10 provides an overall summary.

\section{Refugees in Africa: the Problem}

Involuntary population movements have accounted for more than half of all international migrations since the early decades of this century and constitute an increasing share of current flows. Ironically the main explanatory factor for this trend is the increase in the number of independent states (UN, 1982:84). As elsewhere in the Third World, refugee flows have been significant components of the total African population movement. In Africa, three distinct periods of involuntary migratory movements can be identified: pre-colonial, colonial and post-colonial.

\section{Pre-colonial movements}

Primordially involuntary population movements were caused by socio-historical dynamics internal to societies originating and located within the continent. Recurrent natural disasters also played a significant role in mass displacements in several regions of Africa. External factors started to play an important role in the generation of involuntary movements and mass displacements around the middle of the 15th century. This period coincides with the development of mercantilism in Europe. European mercantilism nourished itself on slave trade and trade in tropical products produced by slave labour. Much of the tropical products for the European markets were then produced in the colonies in the Americas and the Carribean. Millions of Africans (Rodney, 1972) were hunted down and transported by force to those colonies. The slave trade caused not only involuntary movements to other continents but also spurred flight within the African continent itself, as several small nations and ethnic groups abandoned their traditional homes and moved to new regions to avoid the raids and wars that the slave hunters conducted throughout the continent over a long period of time.

\section{Colonialism and displacement}

Mercantilism was replaced by colonialism as a major factor in population displacement. Colonialism caused refugee flows of varying size at various phases in its history. First the conquest and partition of the continent among the colonial powers in itself led to population displacements, as well as to the fragmentation of social and ethnic structures. Ethnic groups were split and fell under various rulers. In the early period, conflicts between the colonial armies and the Africans caused refugee flows in many parts of the continent.

Once their control over their subjects was consolidated, the European settlers also started to use forced labour for the production of commercial crops and minerals. In addition, heavy taxation was levied on Africans as a means of enforcing the recruitment of labour to the mines and plantations (Wallerstein, 1965:151). Resistance to 
forced labour and heavy taxation was often expressed by flight into remote regions within the colonies, or from one territory to another. But flight was not the sole response to repression and colonial exploitation. There were numerous uprisings in which Africans showed their resentment and their desires to be rid of alien domination. Resistance to forced labour and taxation was met with brutality by the colonial establishments, causing internal displacement as well as flight across colonial borders (Polhemus, 1985:31).

As nearly all colonial territories were surrounded by territories with the same status, flight from one region to another provided little escape from exploitation and oppression. In addition, there was always the danger of forced repatriation. Therefore, there were few refugees during the second stage in the history of colonialism in Africa, in spite of the injustices which constituted the modus vivendi of the colonial system. These circumstances also gave the colonial system an appearance of relative stability for several decades after colonization.

The African refugee population began to increase steadily in the 1950s and became acute in the 1960 s, coinciding with the rising tide of the struggle for independence across the vast continent.

The conflict between French colonialism and Algerian freedom fighters caused the flight of 200,000 Algerians to Tunisia and Morocco between 1954 and 1962. The war that was conducted by Portugal in its former colonies of Angola, Guinea-Bissau and Mozambique against liberation forces caused very large population displacements during the 1960s and 1970s. More than 400,000 Angolans sought refuge in neighbouring countries between 1961 and 1972. About one-tenth of the population of Guinea-Bissau (81,000 persons) were in Senegal in 1972. Tanzania hosted 56,000 Mozambiquans during the same period (Holborn, 1975:963-976). Zimbabwe had the same experience during the years of struggle against the regime of Ian Smith, with about half a million of her population displaced.

Since the end of 1979, the African refugee population has increased dramatically and has been a heavy burden upon host societies and the international community. Some of the African countries, particularly those sharing borders with Ethiopia, accommodate refugee populations which constitute a significant proportion of their citizenry'. Thus, refugees today account for 20 per cent of the population of Somalia, 6 per cent of Djibouti and about 5 per cent of the Sudan. In Africa as a whole, the refugee population rose from an aggregate total of about 100,000in the early 1960 s to about five million in 1984.

The interplay of internal and external forces and a combination of socio-political, economic and natural factors are responsible for this mass displacement of peoples. New states which were created at the end of the colonial rule are entangled in the process of "nation" building, and in many cases this process has not been free of conflicts (Holborn, 1975). Decolonization brought new and often powerful political conflicts into play and released older hostilities, thus creating mass displacements. The Biafran conflict in the 1960s and the confrontations in Rwanda and Burundi are some examples of such circumstances.

The moral and psychological consequences of the slave trade and colonialism for the African peoples have yet to be investigated in depth. These phenomena had devastating consequences for economic, as well as social and political, development. The loss of the most productive segments of the population during the several 
centuries of slave trade caused economic stagnation and even regression in many African societies. Mercantilism devastated thriving handicraft and cottage industries by introducing cheap factory-made textiles from Europe (Davidson, 1980).

Many of today's refugee flows in Africa have their root causes in the colonial period. Colonialism has drastically altered the basic parameters for the future development of many African societies. It has stunted socio-economicdevelopment. For a century or more, most Africans were ruled by aliens who used systems and structures which few among the indigenous populations understood or were supposed to understand. When the colonialists left, there was an institutional vacuum. The economic and political systems instituted by colonialism were not adaptable to the new situation either due to a lack of people who could make them work ${ }^{2}$ or simply because the systems were incompatible with the conditions that evolved after independence. Because colonial rule was essentially authoritarian and oppressive, the colonial legacy to African political development was undemocratic practices and intolerance of dissident views. In other words, there were no viable political institutions that allowed democratic participation by the majority. Consequently, political and economic crises are common features of most of the post-colonial societies in Africa. Civilian-style politics, with regular elections and peaceful governmental changes, have not been the norm in post-colonial Africa. Rather, military-led coups d'etat represent the typical way in which regimes are changed, and rule by the military is as widespread as that by civilians. According to McGowan and Johnson (1986:539-546), between 1956, when the Sudan became the first country to achieve independence from colonial rule, and 1985,126 plots to overthrow the government were reported, 71 coups were attempted and 60 coups were carried out in 40 of the 45 independent African countries.

The plunder of human resources by slave traders was followed by the plunder of natural resources and the exploitation of African labour during the era of colonialism and imperialism. By the time the colonial powers left their colonies many African societies were poorer, in several senses, than at the time of their contact with Europeans (Rodney, 1972). Most of the former colonies had to start their economic development from scratch after independence.

Nevertheless, it would be wrong to place all the blame for current African refugee problems at the door of the former colonial powers. The process of nation-building in itself accounts for a significant part of the problem. Moreover, many African leaders are not free of blame. As David Lamb (1983) rightly commented, some of the African heads of states in their insecurity have closed the safety valve of public expression, turned the media into their own vehicles of propaganda and have killed, jailed or sent into exile dissidents and creative thinkers. Wrong priorities characterize the development policies of many African states and scarce public resources are either exhausted on a few prestige projects or on the expansion of military forces which are often used against political opposition. Such policies have contributed enormously to poverty and refugee problems in several countries, not least in Ethiopia. 


\section{Local and International Responses to the African Refugee Problem}

The dramatic refugee influxes and the strained national economies of the countries of asylum have led to involvement of a host of international aid agencies in the relief and rehabilitation of refugees in Africa. The number of agencies engaged in refugee assistance increased from 20 in 1965 to 112 in 1981 (Pitterman, 1984:65-66).

The United Nations High Commissioner for Refugees (UNHCR) is the coordinator of the activities of these organizations and a major contributor to refugee aid in Africa. As a humanitarian agency the policy of the UNHCR is essentially determined by the objective needs of the refugees under its jurisdiction. In addition to providing relief assistance and legal protection the organization is seeking lasting solution through voluntary repatriation and when repatriation is deemed remote or impossible through local integration. Resettlement in third countries of asylum is another method of giving lasting solution to the problem. As this involves only a tiny fraction of African refugees we will not dwell upon it.

\section{Voluntary repatriation}

Voluntary repatriation which means facilitating the return of refugees to their country of origin has occurred in Africa more than in other regions (UN, 1982:91). Thus over the last fifteen years some African countries have experienced the return of their citizens in large numbers from years of exile in the neighbouring states. Some of the successful repatriation undertakings coincided with the end of colonial rule in Guinea-Bissau, Mozambique, Angola or white minority rule in the case of Zimbabwe. In these countries, except Angola, voluntary repatriation proved to be a durable solution as there are very few refugees originating from them today. In the other cases voluntary repatriation was facilitated by the cessation of conflicts, change of government or a declaration of general amnesty. The durability of the solution in these latter cases proved unreliable. The conflicts in Southern Sudan, Chad, etc., persisted and tens of thousands of refugees continue to receive assistance in the neighbouring countries.

Repatriation is the ideal solution to the refugee problem. However as the above examples suggest it is often found to be inadequate when carried out before the elimination of the root cause for flight. Changes of government as in Chad and Uganda or declaration of amnesty as in Zaire in 1978 or in Ethiopia in 1982-83 may halt the flow of refugees or even reverse direction. However, a change of regime is found to be no guarantee when the conflicts that spurred refugee flows do not cease as in Chad and Uganda where such changes brought exiles back home only to be followed by flight.

Neither amnesty declared by military regimes convince many refugees to return home. For example, few Ethiopians returned home after the repeated declarations of amnesty by Colonel Mengistu Haile Mariam. In fact the unreliability of repatriation as a durable solution when the root causes are not eliminated was manifested by the simultaneous movement of Ethiopian refugees in two directions along the same route. While in 1983 the UNHCR was repatriating Ethiopian refugees from Djibouti, other Ethiopians were fleeing to the same country and other neighbouring 
states in masses. Futhermore, many of those who were repatriated fled again to Djibouti and other countries finding the situation both economically and politically insecure (Refugees, no. 24, Dec. 1985:43).

The relationship between a lasting solution and the elimination of "root causes" of the refugee problems has been pointed out by several observers. Some writers are of the opinion that however adequate, well-endowed and well implemented international assistance programmes are, as long as the root causes of deprivation and persecution are not resolved and voluntary repatriation is made possible, the socioeconomic and psychological deprivation caused by flight will continue to affect the lives of millions of African refugees. According to some observers "international aid can offer nothing better than the bleakness of the settlements and camps while the generosity of the poor in host countries can do no more than share their poverty" (Codrignani, cited in Pitterman 1986:136). The leader of the Australian delegation to ICARA II, emphazing the need to deal with the root causes in order to find a reliable solution, stated that,

The root causes of refugee flows are a major part of those problems. A serious effort to understand and remove the causes is the necessary counterpart to responses after an exodus. There is little wisdom in treating only symptoms.

In spite of the obvious relationship between root causes and durable solutions, little effort is being made by international organizations either at the global (UN) or regional $(\mathrm{OAU})$ levels to challenge the refugee problem from that angle. George Metcalfe (1970:73) wrote that international organizations avoid dealing with the causes of flight and pay attention to its symptoms for the pragmatic and honourable goal of maintaining world peace. However, there is a clear contradiction in this sort of pragmatism. Peace cannot be maintained by overlooking the violation of human rights. Neither can it be sustained by relegating refugees to marginal legal status or a class of pariahs kept alive by charity (Karadawi, 1983). Peace is not secured by handling the matter in this way as refugees, in their efforts to win back their rights, can contribute to regional and global conflicts and instability. The conflicts that the Middle East has experienced over the last two decades as a result of unresolved refugee problems point clearly in this direction.

\section{Local integration}

Because of the persistence of conflicts and other causes of refugee flows in several countries of origin, most host countries are confronted with refugee situations where the populations are essentially stable and the dates of repatriation are not imminent (Pitterman, 1984:126). The persistent nature of the African refugee problem is illustrated by the differences between the influx and deflux statistics given in Table 1.1. Between 1963 and 1982, the annual deflux surpassed influx in the African refugee population on only two occasions. Even here it seems that one of the defluxes (1981) was an exaggerated estimate ${ }^{3}$. As can be inferred from the table, many of the African refugee groups have been in the countries of asylum for over 20 years. Although defluxes increased substantially after 1978, the influxes have increased at the same rate. Since 1981 the trend has been increasing influxes and decreasing defluxes, although concrete figures are not available for the African continent as a whole. 


\begin{tabular}{rrr}
\hline Year & Influx & Deflux \\
\hline 1963 & 88.8 & 10.0 \\
1964 & 87.6 & 30.0 \\
1965 & 131.7 & 21.5 \\
1966 & 107.2 & 32.0 \\
1967 & 58.5 & 22.0 \\
1968 & 68.0 & \\
1969 & 64.1 & 17.6 \\
1970 & 56.3 & 23.8 \\
1971 & 25.8 & 23.6 \\
1972 & 137.3 & 21.9 \\
1973 & 69.7 & 67.3 \\
1974 & 41.0 & 121.5 \\
1975 & 322.2 & 21.2 \\
1976 & 99.2 & 287.3 \\
1977 & 446.5 & 56.5 \\
& & 66.1 \\
1978 & 416.3 & \\
1979 & 519.1 & 155.2 \\
1980 & 999.2 & 191.1 \\
1981 & 237.8 & 327.7 \\
1982 & 371.0 & 578.8 \\
\hline
\end{tabular}

Source: These figures are drawn from the aggregate refugee population statistics given in Pitterman (1984), Appendix 1.

There were large influxes of Ethiopian and Ugandan refugees into the Sudan in 1984 and 1985. Mozambiquans had also fled to neighbouring states in large numbers during this period. Repatriation was conducted from Djibouti to Ethiopia. Ugandans and Chadians have repatriated voluntarily in 1986 and 1987. (Refugees, No. 45, 1987).

During the 1960s and 1970s most of the assistance to African refugees was committed to projects promoting local integration. Since the beginning of the 1980s a growing proportion of the UNHCR budget has been committed to multi-purpose assistance, particularly emergency relief operations. This has occurred because of the large influxes of refugees in areas such as the Horn of Africa. The proportion of the UNHCR African budget committed to local integration fell from 94 per cent in 1970 to 44 per cent in 1981. In the meantime, allocations to multi-purpose assistance rose from 2.4 percent to 49 percent (Pitterman, 1984:159). In 1982 only about 20 per cent of the expenditures were for such integration and 60 per cent of the funds were allocated to care and maintenance (Goundrey, 1984). Despite the increasing commitment of assistance to relief, local integration remains the only major solution to most African refugee problems. This fact was recognized by ICARA II, which also emphasized the need for development-oriented assistance that takes into account the needs of the local population.

Two lines or strategies are followed in the integration policy of most host countries in Africa: planned or organized settlements and the "spontaneous" absorption of refugees into the local population. The dominant policy orientation of the UNHCR and some of the host countries like the Sudan is to achieve local integration through 
organized rural settlements. During the last two decades dozens of rural settlements have been organized in eleven African countries to enable refugees to become economically self-sufficient.

The spontaneous absorption view is based on the assumption of minimum interference from the host government or the UNHCR, either because self-settling refugees are expected to fend for themselves (Pitterman, 1984:161) or because they are received by their kinfolk with hospitality. Observers with long experience in Africa consider spontaneous integration to be an erroneous assumption. Robert Chambers $(1979,1984)$ pointed out the economic social and political vulnerability of selfsettling refugees and their impact on the conditions of the poorest in the host population. He assumed this was exacerbated by the depression of wages and the rise of food prices, and other essential commodities and services. Other observers pointed out the decrease in African hospitality due to deteriorating economic conditions, the rising rate of population growth with a doubling of the labour force about every twenty years (World Bank, cited in Goundrey, 1984) and the relative scarcity of land for cultivation.

Although there are instances when international assistance has contributed to the economic betterment of refugees, most of the organized settlements have failed to promote economic self-sufficiency. There are several factors which account for this failure.

The major concentrations of African refugees are found in the least developed countries of the continent. The economies of these countries have deteriorated drastically over the last two decades and are today characterized by rapidly declining agricultural production compounded by natural disasters, increased costs of essential goods, serious problems in the social services, rising unemployment and widespread famine. In this environment refugee economic self-sufficiency is an illusion because, as Pitterman suggested,

we can not expect refugees to become economically self-sufficient in a vacuum . . . refugee settlements can prosper and refugees can contribute to the welfare of the host population only in so far as broader economic integration is fostered (1984:136).

Although the integrated zone approach for planning and organizing the economic development of refugee settlements is not new, developmental assistance which includes the needs of the local population in the refugee affected areas has not been forthcoming. There is a growing consciousness regarding the relation between development and refugee problems. It is now widely acknowledged that local integration efforts cannot be effective unless they are carried out simultaneously with the economic and infrastructural development of the regions in question. However, at the level of action, there is still strong ambivalence particularly on the side of donors and international organizations. 


\section{The Setting of the Present Study}

\section{The Sudan: the land and the people}

The Democratic Republic of Sudan, with a land area of approximately 2.5 million square kilometres, is Africa's largest country. The population of the Sudan is estimated at around 20 million, with about $\mathbf{8}$ persons per square kilometer. This makes the Sudan one of the most sparsely populated countries in Africa. The country is inhabited by peoples who differ linguistically, culturally and ethnically. The northern half is inhabited by Sudanese of African and Arabic stock while the southern half is occupied by various people of African decent. Both groups are further characterized by great diversity in their ethnic composition.

Arabic is the main language in the north whereas the peoples in the south speak various Nilotic vernaculars and use English as an official language. It is perhaps the cultural, linguistic and ethnic heterogeneity, as well as the varying levels of socioeconomic development, which facilitates the rather smooth accommodation of refugees and aliens in the Sudanese societies.

Population growth in the Sudan is about 3.1 per cent per annum (Lees and Brooks 1977:13). The growth is more rapid in urban centres: 7.4 percent as contrasted with

1.5 percent in rural areas. This disparity between urban and rural population is accounted for by the pattern of immigration to the provincescontaining the principal urban centres in Khartoum, Blue Nile and Kassala provinces (Lees and Brooks, 1977:14).

The population of the Sudan is highly mobile. It is estimated that at least one million people move every year (Lees and Brooks, 1977:14). A variety of factors account for the high degree of population mobility in the Sudan. A large proportion of the population move about from place to place in search of better income-earning opportunities. Low productivity in traditional agriculture and the limited carrying capacity of rangelands characterize the traditional sector of the Sudanese economy. Consequently the agricultural work-force, which makes up three-quarters of the total labour force, is substantially underemployed during certain seasons (Lees and Brooks, 1977:18). Therefore, large numbers of people have to move long distances each year to find supplementary sources of income. These movements are further encouraged by substantial income disparities between regions and between urban and rural areas (Kiss, 1977). The pattern of modernization in agriculture has led to a strong geographic concentration. More than $\mathbf{9 0}$ per cent of the irrigated land and mechanized farms are located in Kassala and the Blue Nile provinces. It is to these regions that Sudanese seasonal migrants flow each year from the Southern, Western, Central and Northern parts of the country. The two provinces also receive and accommodate the vast majority of the refugees from Ethiopia.

Another factor which accounts for population mobility in the Sudan is the persistent drift of population toward urban centres, partly associated with the search for better jobs and other opportunities unavailable in the rural areas. Lastly, there is a constant east-west flow of people through the Sudan in connection with the holy pilgrimage to Mecca. Those involved in such movements often take up temporary residence in the Sudan, sometimes for a period of several years, saving money for the next part of the trip (El Beshir, 1982).

Areas that are major recipients of these migrants include the urban centres and the modern farming schemes. Thus the rapid growth of the urban population in the 
Sudan is due to the large immigration to urban centres and towns. Both the urban centres and the eastern provinces of Sudan are the major recipients of migrants not only from inside and outside of Sudan but also of Ethiopian refugees. The concentration of migrants and refugees in these parts of Sudan creates a certain degree of competition for jobs, housing and other social amenities leading in turn to antirefugee feelings and hostilities. Such hostilities do not often come to the surface but are manifested in a variety of ways often invisible to the casual observer. We shall later attend to the ways these conflicts affect refugee adjustment and integration in Sudanese society.

\section{The economy}

The Sudan is categorized by the World Bank as one of the least developed countries in the world. As such the country faces critical economic, social and political problems arising from economic under-development and from an inadequate infrastructure. Since agriculture and animal husbandry are the major components of the economy, recurrent sharp declines in this sector due to weather conditions and deteriorating terms of trade have severely curtailed export earnings and constrained the development of the Sudan.

Unlike many of the poor developing countries, the Sudan has a relative abundance of natural resources which could greatly enhance the standard of living of the Sudanese peoples if exploited properly (ILO, 1984a:2). Land constitutes the most important natural resource which the Sudan has in abundance. Hence agriculture and animal husbandry are the mainstay of the economy. Out of the 600 million feddans ( 1 feddan $=0.42$ acre) of land 250 million constitute grazing land supporting an estimated 45 million heads of cattle, sheep, goats and camels. However the cattle population has been depleted due to recent recurrent drought. Around 200 million feddans of Sudan's land area is potentially suitable for agriculture, although only about 8 per cent of this is currently utilized (Lees and Brooks, 1977:42).

Agriculture supports about 80 per cent of the population. It accounts for 95 per cent of the exports and 40 per cent of the gross domestic product (GDP) (Lees and Brooks, 1977:28-31; Kiss, 1977). Cotton is the major crop for export. Durra, which is produced for both domestic consumption and export, constitutes the second most important crop. As in most countries in Africa, the Sudanese agriculture is multisectored. Different kinds of production relations or combinations of these prevail. Both traditional and modern sectors have important places in agricultural production and the employment of labour. The prevailing conditions in both sectors, as we shall see later on, affect the integration of the refugees into the Sudanese economy and society.

Manufacturing industry is still in its infancy and accounts for less than 10 per cent of the gross domestic product. The growth in the urban population over the last two decades as the result of migration has not been matched by a concommitant growth in urban industrial employment. Only 5 per cent of the country's labour force is engaged in industrial production. In recent years the industrial sector, particularly manufacturing, has fared rather badly. According to the ILO, industrial investment and overall industrial production has remained virtually stagnant since the middle of the 1970s. Capacity under-utilization currently characterizes most manufacturing establishments (ILO, 1984a). 
The declining performance of the agricultural sector and the stagnation in industrial production have meant that, since the middle of the $1970 \mathrm{~s}$, there have been negative growth rates in all sectors and a declining GDP in real terms. Added to this negative domestic economic performance has been a growing foreign exchange crisis. The serious foreign exchange problems have also brought forth reliance on the International Monetary Fund (IMF) which led to the acceptance of its standard policy package: devaluation of the Sudanese pound, removal of subsidies on essential consumer goods and agricultural inputs and curtailment of public expenditure as part of the financial austerity measures. In the last few years Sudan has experienced high rates of inflation. Thus, the urban cost of living index increased by nearly 300 percent between 1978 and 1981. At the time of our survey (1983), the rate of inflation was about 40 percent per year (ILO, 1984a:8). Moreover, the government's budgetary position has been adversely affected by the deterioration of the security conditions in the southern half of the country, leading to larger outlays for defence.

Thus the Sudan is currently facing severe economic setbacks exacerbated by drought, and is unable to provide its citizens with a minimum standard of living. In addition, this period of economic decline has coincided with the influx of about one million refugees.

\section{Refugee movements into the Sudan}

Few countries could have better reasons than Somalia and the Sudan to be restrictive in their refugee politics considering the poverty and the suffering of their own peoples and plead instead to international solidarity . . . No such refugee-rejecting practices have ever been heard of in the Sudan and are seldom reported from Africa (Nobel, 1982:3).

The location, the hospitality of its people and the liberal policy of the government have long made the Sudan a destination for refugees. Hospitality to strangers and helping those in need is a strong element in the Sudanese cultural fabric and moral code. Hospitality is not only a religious obligation but an effect of structural factors. Centuries of migratory movements within and across the country have made contacts with strangers a common phenomenon for most Sudanese and has engraved the tradition of hospitality upon the society. This is also reflected in state policy regulating the provision of asylum. In this century, the Sudanese people have hosted influxes dating back to 1906 when large groups fled from the Belgian Congo. In 1936, when Italy attacked Ethiopia, thousands of Ethiopians sought and received asylum in the Sudan which was then under British colonial administration (Documentation For Khartoum Conference, Vol. II, 1980:2).

The refugee problem in the post-independence period begins with the influx of Congolese into the Province of Equatoria in 1965, soon to be followed by the exodus of 30,000 Eritrean refugees in 1967 (UNHCR, 1981:45). Since then a steady trickle of refugee influx has continued to arrive, turning into massive waves from 1975 when the effects of a revolution and a subsequent military coup deposing Haile Selassie began to be felt in Ethiopia. Table 1.2 gives the trend of refugee population growth in the Sudan beginning in 1974, the date of the Ethiopian revolution.

At the time of our field survey there were nearly half a million refugees from Ethiopia in the Sudan representing different national, cultural and linguistic backgrounds. The refugee influx from Ethiopia increased dramatically in 1984 and 1985 
Table 1.2 Refugee influx into the Sudan by year and country of origin (in thousands)

\begin{tabular}{lccccr}
\hline Year & Ethiopia & Zaire & Uganda & Chad & Total \\
\hline 1974 & 49.0 & 4.5 & 0.0 & 0.0 & 53.0 \\
1975 & 85.0 & 5.0 & 0.0 & 0.0 & 90.0 \\
1976 & 105.0 & 4.5 & 0.5 & 0.0 & 110.0 \\
1977 & 145.0 & 4.5 & 0.5 & 0.0 & 150.0 \\
1978 & 270.0 & 3.5 & 0.5 & 0.0 & 274.0 \\
1979 & 346.0 & 3.5 & 0.5 & 0.0 & 350.0 \\
1980 & 390.0 & 5.0 & 69.0 & 16.0 & 480.0 \\
1981 & 419.0 & 5.0 & 110.0 & 18.0 & 552.0 \\
1982 & 440.0 & 5.0 & 160.0 & 22.0 & 627.0 \\
1983 & 460.0 & 5.0 & 184.0 & 0.0 & 649.0 \\
\hline
\end{tabular}

Sources: UNHCR Official records and annual reports to the General Assembly; Sudanow, June 1981; Nobel, 1982; Refugees, No. 5, 1983.

In June 1987 there were about 974,000 refugees (mainly from Ethiopia) in the Sudan (Refugees, No. 43, 1987).

due partly to the escalation of conflicts between the government forces and the various national movements, and partly to the devastating drought situation which hit mainly the northern regions of Ethiopia. During the same period, Ugandan refugees also fled to the Sudan.

\section{Impacts of influx}

Refugee influxes give rise to problems of a very complex nature: for the refugee the problem concerns personal survival and making the best of the conditions encountered in the new environment; for the world community, if at all, the problem is a humanitarian issue to be forgotten as soon as the acute needs are partially satisfied. For the host country it creates a complex series of problems. The impact of the massive influx has affected the fragile Sudanese economy in a number of ways. The refugee presence is said to have put severe pressure on social services and the infrastructure. Refugee children, it is argued, burden the school system in provinces like Kassala where the concentration of the refugee population is the heaviest (UNHCR, 1984:148). El-Bushra (1982:4) pointed out that in some areas with high refugee concentrations the proportion of refugee children in Sudanese schools is often as high as 50 per cent. The water consumption by refugees was estimated at about one billion gallons per annum (UNHCR, 1984:148). This has exacerbated the inadequacy of the water supply, particularly in north-eastern and central Sudan.

The refugee presence is also considered to have negative healthcare effects. The danger of spreading new diseases to the local population is one concern among Sudanese health workers. Besides, and more pressing, there is the problem caused by the pressure of the influx on the existing health services. Dr. Hassan Bella Elamin wrote that,

24 per cent of hospital beds in Kassala were occupied by refugees in 1980, 200 refugees attended the out-patient department of the same hospital every day, 69,590 refugees 
attended Gedaref hospital in 1979,2,615 of them were admitted to the hospital, and 949 of them needed surgery $(1980: 9)$.

Elamin adds that rural hospitals, dispensaries and dressing stations in all the refugees affected provinces are similarly impacted. The refugee pressure also has adverse environmental consequences. According to UNHCR estimates, 800,000 acres of forest have been cut for huts and fuel by Ugandan refugees, and wood valued at £S 20 million has been cut by refugees in recent years (UNHCR, 1984:148).

Other observers have suggested the differential effect of the refugee presence on the different classes and strata within the host population. A large refugee labourforce which is available when needed, is more reliable, cheaper, and enables rich landowners to cultivate larger areas and increase profits. However, it reduces employment, lowers wages and raises food prices and rents for the labouring classes of the host society (Chambers 1984:9). This, as we shall see later, constitutes a factor affecting social relations and integration between the two communities.

There are also observers who are of the opinion that the negative effect of the refugee presence is exaggerated. Weaver, while admitting the burden that refugees may put on services, questioned the validity of blaming them for the decline in standard of living and shortages of goods and services. He wrote,

Ethiopians are a convenient scapegoat because the economic decline and their arrival are coincidental . . . Indeed should the government remove obstacles to business and professional employment the refugee community could play a much bigger part in the national development and economic growth (1985:155).

Whatever the case may be, the presence of such a huge number of refugees, a large majority of whom live scattered among the local population, constitutes a burden on the host society. The refugee influxes into the Sudan have undoubtedly placed heavy demands on administrative, financial and infrastructural resources which are already insufficient and overtaxed. In a country which is currently hit by one of the worst famines in modern times, refugees must be given food. In a country which is facing severe housing problems and the resultant rapid growth of shanty towns, they must be sheltered. Refugees are mainly young and seek education in asystem marked by a severe scarcity of resources even for indigenous children. They put pressure on a job market that is already characterised by unemployment. Obviously, refugees represent an economic potential which could be of significant value to the economy of the host country. But this is not yet imaginatively and effectively tapped.

\section{Responses and solutions}

The Sudan is a signatory of international conventions like the 1951 UN Refugee Convention, the Protocol of 1967 and the OAU Refugee Convention of 1969. Moreover the spirit and the main principles of these conventions are embodied in the Asylum Act of the Sudan promulgated in 1974, which defines the eligibility procedures and the authority responsible for granting of asylum. In some respects the Asylum Act of the Sudan is more generous than other existing conventions and national legal instruments regulating asylum (Nobel, 1982:21).

In effect the borders of the Sudan are open to all who have reason to fear for their lives. Such an "open door" policy does not end with the provision of asylum but also involves responsibility for the welfare of those that are given free haven. In coopera- 
tion with the UNHCR, the WFP, the FAO, the UNDP and a host of voluntary agencies, the government of the Sudan has provided direct assistance, to significant proportions of the refugee population.

Because of the experiences gained from a long history as host to refugees fleeing turbulent neighbouring states, as well as the lessons learnt while integrating its own citizens who returned en masse from exile at the end of the north-south conflict in 1972, the Sudan has one of the most developed refugee policy apparatuses and well-organized infrastructures for the administration of refugee assistance.

\section{Types of refugees and settlements}

There are two major types of refugees in the Sudan: urban and rural. Between one-third and one-half of the Ethiopian refugees in the Sudan are found in urban areas, whereas the rest are accommodated in rural settlements. At present refugee settlements in the Sudan follow two major patterns: spontaneous and systematic settlements. In the spontaneous pattern the refugees are self-settled and live scattered among the local population. The systematic settlements are organized and run by the host government with assistance from the international community. In most cases, organized settlements accommodate only refugees.

The enormity of the problem and the remoteness of prospects for voluntary repatriation has convinced the Sudan government to develop large scale and ambitious settlement programmes. The primary goals of the settlement projects were given by the National Committee for Aid to Refugees (Documentationfor Khartoum Conference, Vol II, 1980:3) as first and foremost to enable refugees to be productive and self-reliant in the shortest time possible. The projects also aim to phase out both camp life and spontaneous settlement. Camp life causes socio-psychological damage to refugees, while spontaneous settlement results in pressure on resources and causes micro- and macro-political tensions.

Three categories of systematic (organized) settlements have been established in Eastern Sudan where most of refugees fromEthiopia are concentrated. Since a large proportion of the influx consists of persons or groups of rural origin, the majority of the settlement schemes have been agriculturally based.

In the first category, refugees are provided with plots of land ranging from five to ten feddans per household. This category of organized settlements are known as land settlements and their inhabitants are expected to subsist on the income from crop cultivation, animal husbandry and occasional wage labour. The second category are known as wage-earning settlements and are situated inside or in the neighbourhood of national agricultural schemes and privately-run commercial farm enterprises. These are expected to provide refugees with wage labour employment. The third category of settlement, the semi-urban, are few in number and are located close to towns. They are similar in principle to the wage-earning settlements and at least some of the employment is expected to be of an urban character.

In 1984 about 100,000 persons, or approximately 22 per cent of the refugees from Ethiopia, were accommodated in 23 systematicallyorganized settlements in eastern and central Sudan. The majority (78 per cent) were living scattered in urban and rural areas. In southern Sudan about 83 per cent of the 200,000 Ugandans were accommodated in organized settlements.

The administration of refugee affairs is conducted by a specialized agency - the 
Office of the Commissioner for Refugees (COR) - which was established in 1967. The COR is responsible for the determination of the status of individuals and groups who seek asylum in the Sudan, the procurement of outside assistance for refugees and the coordination of government efforts with those of the UN agencies and voluntary organizations. 


\section{Chapter 2}

\section{The Mass Exodus from Ethiopia: Historical Background}

\section{Introduction}

As indicated in the introductory chapter of this book, one way of understanding refugee exoduses is by conceptualizing them as part of the dynamic macro-sociological process of history of the peoples and regions concerned. The social conflicts that produce refugees result typically from the constellation and interaction of internal and external forces, intelligible in terms of the historical development of society. The Ethiopian situation, as will be shown below, is an archetype. Therefore, the problems of the refugees from Ethiopia cannot be adequately understood without examining the objective historical roots, that is, the formation of the Ethiopian empire state and the economic, social and political relations which have characterized the pluralistic Ethiopian society since the turn of the century. Such an historical and holistic approach renders possible a genuine comprehension of the problems that can in turn lead to meaningful recommendations for short- and long-term solutions.

In the previous chapter it was noted that the underlying cause of the African refugee problem is the colonialism that has affected the continent over the last one hundred years. Ethiopia, contrary to what is generally maintained, did not escape colonialism. The present mass exodus, uprooting and misery of people from Ethiopia has, by and large, its roots in the fateful events which led to the drawing of the current state boundaries in Africa. A large percentage of the respondents in this study indicated that they were victims of the colonial division of the Horn of Africa, and relate the solution of their problem to the resolution of the nationalities question in Ethiopia. Hence, in order to come to grips with the conflicts and cleavages that characterize the current Ethiopian political scene, the formation and nature of the Ethiopian Empire* state must be analyzed.

\section{The myth of 3000 years}

Addis Hiwet (1975) has suggested that in order to have a clear picture of the history of the peoples in the country known today as Ethiopia we must dismiss the myth that blurs and distorts genuine historical understanding. He wrote that the origin of the name Ethiopia and the country is enshrined in a myth which distorts the history of most of the peoples that live in it. The gap between reality and the myth about

\footnotetext{
* Until the revolution of 1974, Ethiopia was known as the 'Empire of Ethiopia' and the ruler bore the title of Emperor and the government was 'the Imperial Ethiopian Government'.
} 
Ethiopia was also observed by other writers as "unusually wide" (Perham 1969). This myth was created by the Abyssinian kings, their court chroniclers and the ideologists of the ancien régime and presents Ethiopia as an ancient state which existed for millenia with a traceable line of continuity and unity ${ }^{1}$. Much of the myth about Ethiopia is not about the $\mathbf{4 2}$ million people who live within its boundaries but about a tiny ruling class and the nation (Amhara-Tigre) from which this class originates. What is often distorted by the myth is the history of the peoples that were conquered and incorporated into the Ethiopian empire at the end of the last century and the beginning of this century. The myth was fabricated to function as an instrument of exploitation and as justificationfor the actions and domination of the ruling class over the conquered nations and nationalities.

\section{The Conquest and Colonization of the Oromo, Sidama and Other Adjacent Peoples (1876-1909)}

Notwithstanding the myth of 3000 years, the existence of Ethiopia as a state within its present geographical boundaries does not predate the end of nineteenth century. In fact some of the regions were incorporated just before and after World War II - the Oromo Kingdom of Jimma, for example, was incorporated in 1933, and Eritrea was annexed only in 1962. Thus Ethiopia as a state is not much older than the Sudan, Kenya or any other African state.

The foundation of Ethiopia was laid down between 1876 and 1909 (see Map 1) through a process of conquest, annexation and subjugation of independent territories and peoples by the armies of Menelik, the ruler of one of the four Abyssinian fiefdoms and vassal of the Abyssinian Paramount King Yohannes IV. The territories were together several times larger than Abyssinia in both area and population, and their peoples differed culturally, linguistically, racially and historically from the conquering Abyssinians. As Trimingham (1976:135) has correctly remarked Menelik converted what had been sovereign independent states to the hegemony of one over the rest. It was the work of Haile Selassie to begin the process of consolidation into a unitary empire divided into standardized provinces.

The Abyssinians were Christians of mixed Semitic and Cushitic race who believed that their ancestors had migrated from Arabia during the first millenium B.C. They had a common literary language of Semitic origin - Geez - and speak dialects (Tigre, Tigrinya and Amharic) from it. They lived in the mountainous regions of the north and central highlands (Gojjam, Gondar, Tigray, Eritrean highlands, northern tip of Showa and northwestern parts of Wollo) and shared a common culture. They had a feudal socio-political organization with the paramount king of kings as the nominal head. The conquered peoples were mainly of Cushitic and Nilotic stock and were at the time of annexation and colonization at various stages of social and historical development, ranging from pastoral democracies to kingdoms with highly centralized administrations. 


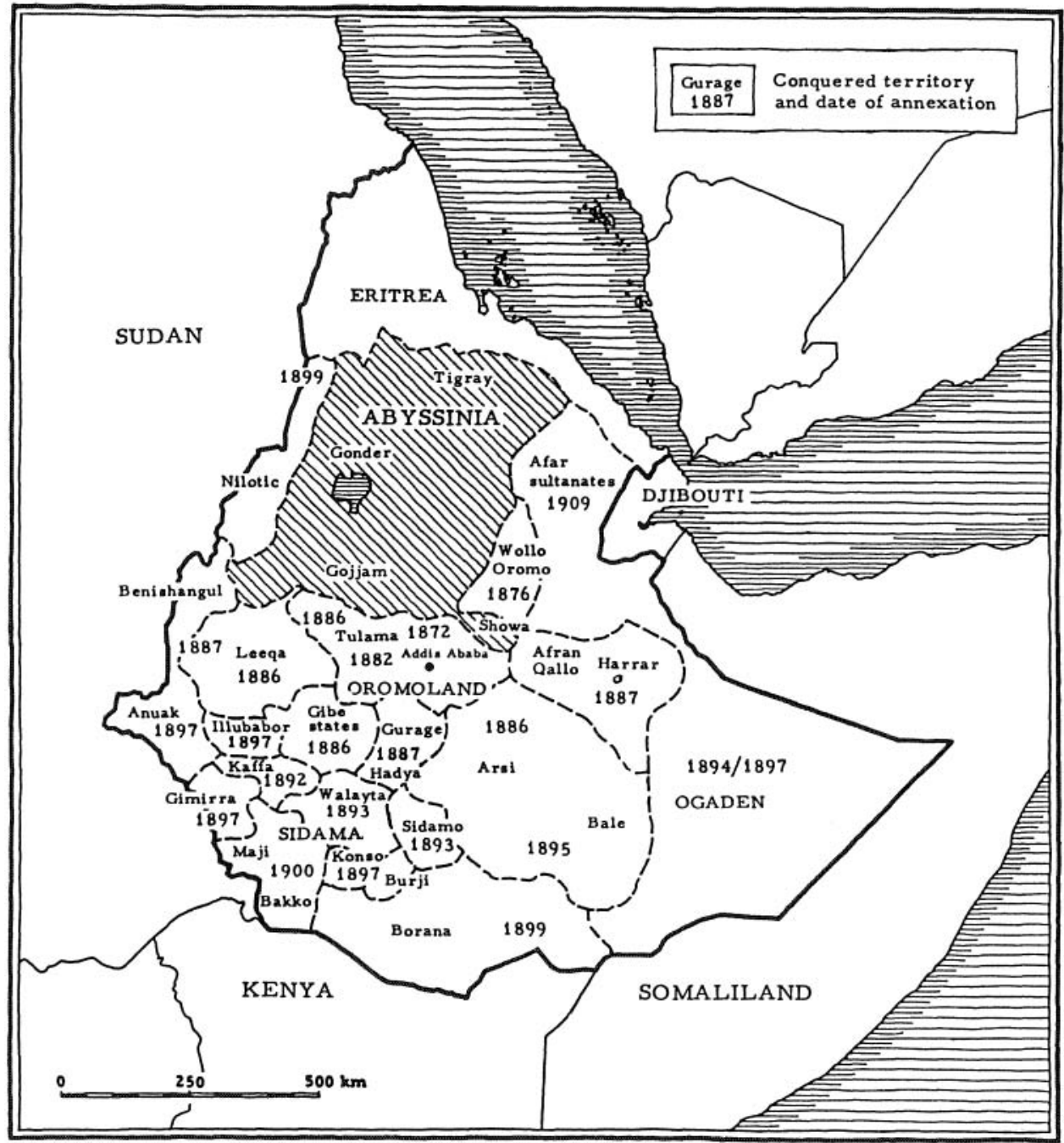

Adapted from Trimingham (1976)

Motives and justifications

Scholars (Cerulli, 1917; Waugh, 1936; Perham 1969; Pankhurst 1966; Baxter 1978, 1983 and Triulzi, 1980,1983) who have studied the societies in Ethiopia have pointed out the colonial nature of the Ethiopian state and the colonial characteristics of the relations between the peoples of the conquered territories and the Abyssinian rulers and settlers. However, Abyssinian rulers and writers have pointed to motives other than colonialism, as the justificationfor their conquest and annexation of the south.

Abyssinian rulers usually justify the conquest in terms of the reinstitution of Abyssinia's old frontiers or the unification of Ethiopia. Lately some Ethiopian writers and politicians have added anti-imperialism, or the attempt to forestall 
imperialist advances in the Horn of Africa, to the list of motives for the conquest of the south (Teshome Kebede, 1982). It is maintained that the Abyssinian conquest and annexation of adjacent territories during the Scramble for Africa was a "feudal expansion" and not a colonial undertaking. The underdeveloped state of the Abyssinian forces of production at the time of conquest is cited as a supportive argument ${ }^{2}$.

Regarding the development of productive forces it is argued that colonialism is and can only be a product of capitalism, and that "a colonial relationship does not and cannot possibly exist between the conquered and the conquerors of the Ethiopian empire", ${ }_{3}$. This assumption tends also to erroneously relate colonialism with race and colour and posits that Abyssinians who are Africans and black cannot possibly be colonialists. Geography is also suggested as a determinant factor in the definition of colonialism whereby colonialists are presented as those who cross seas and conquer territories inhabited by other races. But the subject nationalities see their situation as colonial domination comparable to that of other Africans under European rule (Melbaa, 1980). Differences of opinion regarding the origin and nature of the Ethiopian empire state were among the major causes of a split in the Ethiopian student movement in the early 1970s and for major cleavages in the civilian left along national lines in the post-revolution period (see Healy, 1983; Triulzi, 1983).

\section{The fallacy of the arguments}

None of these argument in defence of conquest finds concrete validity when the historical relations between Abyssinia and the conquered territories, the linkages between the Abyssinian conquest and expansion and imperialism and the treatment of the subject peoples under the rule of the Abyssinian, mainly Amhara, conquerors are critically examined.

The reinstitution of lost territories and the unification argument lacks validity for several reasons. As we have already mentioned the Abyssinians were not in control of the south until the end of the 19th century. They had had only sporadic contacts with some of the Sidama kings and had extracted occasional tributes from them, but sustained Abyssinian control over the whole area lacks valid historical support. Hence "unification" is not found to be a plausible argument since it is not possible to unify or talk about the unification of a country that did not exist before. The name Ethiopia, which was taken from the Bible where it refers to black peoples and not a specific region or nation, came into common use only after the end of World War II. Before that its use in reference to Abyssinia or parts of the Horn of Africa had been inconsistent and rare.

In addition, it is very difficult to conceive of the treatment of the local population by the conquerors as an act of unification. As we shall see in a later section the inhabitants of the conquered territories were subjected to characteristic colonial treatment: they were sold as slaves and exploited as gabbars or serfs. Being mere subjects with no political, religious or social rights they were referred to as dependents in official documents. Before the law of the conquerors, they were mere inhabitants and not citizens of the Ethiopian empire. What we witness here is not the relationships or conditions that prevail in a country after unification. This was not the case with Bismarck's Germany, or Cavour's and Garibaldi's Italy. The conditions and social relations which obtained in the conquered areas following the Abyssinian 
rule were characterized by the superimposition, on the basis of national criteria, of inequalities in political status, economic participation, educational opportunity and fundamental human rights. There was legal differentiation between the subject peoples and those in the conquering areas, as reflected among other things in the gabbar and rist (inalienable right) land holding systems. A society that is built on such flagrant inequality is only a colonial one.

The anti-imperialist justification is not tenable because it is contradicted by facts that show clear linkages between the Abyssinian expansion and European imperialism. To begin with, attempts to conquer their neighbours started rather earlier than European penetration into the area. It was not full scale because of lack of resources. Hence, it cannot be argued that the conquest was undertaken to forestall or hinder imperialist inroads into the Horn. In addition, after the Europeans got a foothold, the Abyssinian ruling class collaborated with them to divide the Horn (cf. Trimingham, 1976:132). Hence, it would not be plausible to consider it (conquest) progressive and anti-imperialist as Teshome Kebede (1982:208) asserts. The Abyssinian rulers, as was evidenced by the joint Anglo-Abyssinian expeditions of 1900-1904 against the historic anti-colonial Somali movement led by Muhammed Abdulla Hassan $^{4}$, actively collaborated with the imperialists against fellow Africans who waged anti-imperialist struggle. The colonial nature of the Abyssinian conquest, in addition to its dependence on imperialist support, was manifested in the conditions imposed upon the subject peoples and the relationship which emerged between them and their conquerors particularly those who settled in the annexed territories. These relationships are common features of colonialism everywhere irrespective of epoch or the dominant mode of production of the colonizing nation (Holcomb, 1984:5-6). These features are:

1. the settlement of aliens in a territory originally in the possession of a distinct nation or nationality,

2. the use and redirection of indigenous labour and the extraction of surplus from the conquered to mitigate contradictions within the socio-economic system of conquering nation,

3. the reliance on externally derived personnel to administer the occupied areas and to control its inhabitants,

4. the suppression of the organizational and cultural life of the indigenous peoples,

5. the ideological justifications from within the socio-economic system generating colonization, and

6. the indigenous responses which opposed colonization and exploitation.

Thus the arguments which have been forwarded to illustrate the non-colonial nature of the Abyssinian conquest do not reveal any essential differenes between European colonialism and the Abyssinian occupation of the Oromo, Sidama and Somali territories in the south, the southeast and the southwest. Moreover, a closer examination of the socio-economic and political relations in the conquered territories leads to the conclusion that Abyssinia (later Ethiopia), irrespective of her underdeveloped forces of production, was a de facto colonial state. There are of course certain differences between Abyssinian and European colonialism. These differences are not determinant because they do not change the colonial nature of Abyssinian expansion. One of the differences is that as a colonial power Abyssinia 
was not independent but was under the direct influence and control of European colonialism. Even if the attempts of Abyssinian kings to enlarge their territories at the cost of their neighbours predate the European scramble for Africa, their expansionist ambitions were enhanced and supported by European colonialism and imperialism. Abyssinian expansion into the neighbouring territories, and the formation of what is later termed the Ethiopian empire, would not have been possible without the decisive military support provided by the European powers.

\section{Dependent colonialism: an historical anomaly}

In a seminal paper, Holcomb has identified two features or rather types of colonialism that concurred in the partition of Africa at the turn of the century. The first type of colonialism is that which was conducted directly by the capitalist states who wanted markets for industrial products and raw materials for industries. The second type of colonialism was carried out by a proxy or an agent state. Such a state had its own institutional structure and its own agenda but, due to the under-development of its socio-economic base, was unable to accomplish colonization on its own in an era dominated by imperialism (Holcomb, 1984:8). Holcomb calls the latter type of colonialism dependent colonialism, and cites Portugal and Abyssinia as the archetypes of dependent colonizer states. She adds that dependent colonizers are "the creation of imperialism extending their states into new territories, holding, subjugating, exploiting others as colonies".

Why did European powers help Abyssinia when they themselves could colonize those territories? Why did not they colonize Abyssinia? Was Abyssinia strong enough to resist colonization?

The main reason for the avoidance of the direct colonization of Ethiopia by European powers was the diplomatic stalemate regarding control over this area, which gained significant strategic importance with the opening of the Suez Canal in 1969. By the middle of the 1880 s the two major European powers of the time, France and Great Britain, and Italy supported by Great Britain had each acquired colonial footholds on the Red Sea and Indian Ocean coast in the Horn of Africa. Their interests were in conflict regarding the hinterlands consisting of Abyssinia, the rich Oromo and Sidama countries, the Afar and Ogaden regions. However, they had to avoid direct conflict over these territories because a war in the Horn of Africa may have led to confrontations elsewhere. The outcome was the inclusion of this region in the general detente reached between these powers, with Abyssinia a junior partner in the partition of the free territories in the Horn of Africa. Thus, Abyssinia was fitted in the overall plan of imperialism in Africa both to her own advantage and that of her imperialist partners. This advantage, and the conflicts between the European powers, were subsequently exploited by the Amhara in building their empire.

Another factor which seems to have played an important role was the costly job of conquest and control of a hostile and relatively inaccessible region. Hence, the conquest and administration of the territories in the region was left to the Abyssinians to carry out while the Europeans extracted the products through the market. As a German sociologist conversant with the social histories of the peoples of this region has put it:

It seems though that Ethiopia remained uncolonized because European powers could confide in her own (Abyssinian) nobility and Emperors the job of colonizing the Empire's 
population. There was little to extract through military conquest and colonial rule which could not be extracted more easily with the help of trade (Pausewang, 1978: 49-50).

Abyssinia's military resources in relation to the territories to be annexed did not allow her to carry out the conquest and colonization all alone. Therefore, one of the rulers of Abyssinia, Menelik, sought and was given massive support in terms of modern weapons and military expertise. I.M.Lewis has indicated that,

Britain. France, Italy and Russia poured arms and some military advisors into Ethiopia, each believing that it would acquire a corresponding measure of local leverage (Lewis, 1983:3).

In addition, modern weapons from European factories were imported in great quantities. Neighbouring nations were denied every access to the weapons market by Italy, France and Great Britain, who controlled not only the market but also the ports of entry into these territories. As Luckman and Bekele have correctly noted,

... he (Menelik) was able between 1880 and 1900 to import over one million rifles, a quantity of hotchkiss guns and artillery pieces, also making use of French and Russian military experts to train his soldiers in their use. No other pre-colonial African state had been able to build such an armory (1984:11).

European military experts not only trained the Abyssinian soldiers but participated directly in the war of conquest as commanders of military expeditions, map makers and strategists (Waugh, 1936:22; Jesman, 1958:93ff). For example, Russian officers accompanied expeditions that Menelik despatched for the conquest of the south and the south-west. Some of these officers were well-known figures and commanders of the Abyssinian forces. Colonel Artamonov together with other Europeans was attached to the forces of Ras Tessema. Lieutenant A.K Boulatovitch, a military engineer, was a commander and advisor in the 30,000 man army of Ras Wolde Giorgis during the conquest of the Kingdom of Kaffa and Maji. The most wellknown Russian in the service of Menelik during the conquest was Colonel Count Nicholas S.Leontiev. He was the commander of one of the Abyssinian forces sent against the southwest. During the expedition Leontiev's second-in-command was Baron Chedeuvre, an officer of the imperial Russian army. Several Russians and Frenchmen were attached to Leontiev's forces as fighters and medical officers (Jesman, 1958: 119-120). For their services the Europeans were compensated by the Abyssinian Emperor with titles and very generous shares in the spoils of the conquest ${ }^{5}$. What we have indicated and discussed above makes it very clear that the Abyssinian conquest of the Oromo, Sidarna and other territories was not a mere act of feudal expansion or feudalist state formation. The Abyssinian feudal class did not accomplish the conquests through their own resources. Prior to the conquest Abyssinia was an impoverished and bankrupt feudal state. Its southern flank, the diminutive mountain fief of Showa*, was in no position to carry out a war of conquest against its numerous and militarily strong neighbours like the Oromo.

It is impossible to conceive of the conquest and colonization without the large scale transfer of technology in the form of modern weapons and military expertise which

\footnotetext{
* N.B. the present Ethiopian province of Showa in which Addis Ababa is located is not the same as the Abyssinian Kingdom of Showa (Shoa).
} 
Abyssinia received from European countries and the military and political alliances that were cemented between the Abyssinian ruling class and imperialism. In fact, the relations between Abyssinia and the European imperialist powers could, as Pausewang (1978:50) pointed out, be considered as the first experiment in neo-colonialism in Africa. The neocolonialist strategy of economic penetration rather than physical occupation of the region became more evident following the defeat of the Italian army at Adawa in 1896 by the forces of Menelik II. European businessmen and prospectors arrived in large numbers in Addis Ababa to share in Ethiopia's potential wealth. Concessions for the construction of railroads, dams and the prospecting of mineral wealth were signed, corporations were founded and firms were established in the capital and the newly conquered south and southwestern provinces. Several treaties, mostly trade agreements, were signed between Menelik II and Britain (in 1896, 1902 and 1907), France (1897, 1908), Italy (1897, 1900, 1906 and 1908), Germany (1905), Belgium (1906), Hungary (1905), U.S.A (1903). A Tripartite Treaty was also signed in 1906 between Britain, Italy and France concerning economic spheres of influence in Ethiopia (Norberg, 1980:330-331). Very few of these ventures were successful as conditions in the Ethiopian empire limited every chance for European capital to profit and expand (Zewde, 1984:331-337). The colonial feudal order that was imposed on the conquered areas had debilitating effects on both production and exchange.

\section{Basic Features of Abyssinian Feudal Colonialism}

In Chapter 1 it was pointed out that European colonialism in Africa resulted not only in economic exploitation, but it also drastically altered the basic parameters within which the colonized societies could evolve. However, the impact of colonization on the indigenous societies was not uniform throughout Africa. Some writers (Rodney, 1972; Holcomb, 1984; Tuso, 1986) argue that there is a discernible relationship between the degree of colonial oppression and exploitation and the level of economic development in the colonizing country. According to this view the more developed the colonizing nation, the less harsh the treatment imposed on the colonized society and vice-versa. Tuso (1986:29) maintains that the British and French colonial processes were less harsh than those of the Portuguese. The Portuguese, while demanding and extracting more wealth and services than the British and French colonial rulers, gave back much less in terms of education, health and other services. Writing on the Portugese and Abyssinian forms of colonialism Holcomb has also pointed out that,

the economic weakness $(\ldots)$ of these systems gave them very little latitude and actually forced them to practise forms of colonialism without subtlety - blunt, crude extraction of materials and harsh suppression of the indigenous peoples in the safety zones granted them by international treaty $(1984: 3)$.

\section{Expropriation and depopulation}

Like European colonialism, the main motive of the Abyssinian conquest was economic. But the mode of surplus extraction was crude and the effects of economic 
exploitation exercised by them were aggravated by the underdevelopment of their forces of production. Their lack of democratic traditions exacerbated the degree of national oppression they exercised upon the colonial peoples. To begin with, the Abyssinian conquest and colonization of the southern peoples was accomplished through destruction on a scale that has few parallels in African colonial experience. In the battlefields, the imported modern weapons which the Abyssinians deployed with the assistance of European mercenaries devastated the armies of the indigenous peoples. As pointed out above these were denied access to modern weapons and had to face the conquerors armed only with spears and shields. Waugh (1936:23) wrote that, in a single battle that took place south of Jijiga in 1899, about 9000 Somalis were killed. Melbaa (1980:43) claims that during the conquest of Arsi, which took about 6 years, 100,000 Oromos were annihilated. According to the Ghanian historian, Kofi Darkwah 1978:195), about 12,000 Arsi warriors were left dead after a single battle which took place on September 6, 1886.

The war of conquest severely affected the civil population. Wherever the indigenous peoples put up resistance, mutilation and devastation followed. An example is the "Arsi mutilation" of 1887. One year after the final defeat of the Arsi Oromo, all the strong men and women of the area were ordered to come to Anole (about $25 \mathrm{~km}$ north of Assala) by the Abyssinian general Ras Darge.

When the people came, they were told to enter the narrow pass one by one. All males who entered were cut off their right hands on orders of Ras Darge. The Shoans (conquerors) tied the hand they cut to the neck of the victim. In the same manner, the right breasts of the women were also cut and tied to their necks. As a result everybody who went to Anole . . returned by (sic) losing his right hand and (her) breast. This is widely known as "Harka Mura Anole" (Abas Haji, 1982:42).

Hundreds of such incidents were inflicted in order to drive fear into the psyche of the conquered peoples and break them into total submission. And it had its effect. They fear and hate the naftanya, even though this does not mean total subjugation to their rule. Because of the violence of conquest there was a drastic reduction in the population of the colonized territories. Martial de Slaviac, a French historian and traveller who knew the area, wrote in 1901 that the Oromo people were reduced to half of their preconquest size and the people of Kaffa were decimated to about a third. Major Henry Barley, explorer, ivory hunter and a British frontier agent who came to Maji, Kaffa a few years after the conquest wrote that,

... Menelik clinched his victory by the slaughter or deportation of two-thirds of the unhappy population ... Signs of a vanished population abounded, and one could easily deduce the stages by which human industry had been stamped out by noting the varying height of the comparatively recent growth of forest (1926:198-199).

In addition to their cruelty, their rapacity and shortsightedness in the exploitation of resources contributed to the further decimination of the conquered peoples. Krapf, a German missionary who followed an expedition of Sahle Selassie, King of Showa and the grandfather of Menelik II, against the neighbouring Oromos in the $1840 \mathrm{~s}$, recorded in his diary:

I did not care much to know the name of the Gallas (Oromo) villages, as they are destroyed almost on every expedition. The soldiers take all they can get in the houses, and then burn them. As the harvest was over, the King could not, as he generally does, burn the fruits, but much wheat was destroyed with the houses (cited in Greenfield and M. Hassan, 1980:7). 
Menelik's expeditions of conquest followed more or less the same pattern. The Abyssinians returned to Showa with tens of thousands of heads of cattle after each expedition. It is recorded that, on a single expedition against the Oromo in 1883, Menelik looted about 66,000 heads of cattles from the inhabitants of the Arsi highlands (Abas Haji, 1982:38). Hundreds of such expeditions depopulated, impoverished and starved the subjugated peoples for decades.

The realities of the conquest were indeed very harsh. The memory of this period and the decades following is kept alive by continued national oppression and Amhara rule, and adds fuel to social conflicts in Ethiopia.

\section{Slavery}

One of the relatively well-recorded consequences of the conquest was the institution of slavery. Although some form of slavery did exist in some of the conquered societies before the coming of the Abyssinians, it was intensifed by the greed of the conquerors. The cruelty and short-sightedness of the slavers denuded several districts in the southern and south-western marches of the empire and turned them into deserted wildernesses:

(the) most severe loss of population occurred after the conquest. Looting ceased to be profitable. Neither people who were not peasants, nor land without peasants on it produced a profit for the conquerors so they availed themselves without serious restrictions of the only profitable source of income they could drive from the province (Kaffa): they sold the people as slaves (Pausewang, 1978:91).

Slave raiding and trade was organized on a large scale by the Abyssinian administrators of the conquered territories. Darley has written that,

The Kenyasmatch (governor) was expecting shortly to be relieved of his command, and therefore catching and selling the local population as rapidly as possible in order to provide for a rainy day $(1926: 200)$.

Slave trade was not limited to provincial administrators. According to various sources 'Menelik himself was Ethiopia's greatest entrepreneur and expropriated ten per cent of all captives taken' (McClellan, 1980:71; Marcus, 1975:73). Some of the slaves were locally employed as domestics in the palaces of the emperor, the feudal lords and the settler households, but the majority were exported to markets in north Africa and Arabia, providing an important source of revenue for the colonial state. The war of conquest and the slave trade also generated refugees. Darley wrote that the indigenous people in Kaffa fled into the forests and to the Sudan to escape slavery. Another writer noted that,

the first exodus of refugees fled Oromo lands in the late 1880s following the incorporation of Oromia into the Abyssinian empire. Able-bodied men left their wives and children, opting to live under British colonialism in surrounding countries rather than fall victims to anihilistic policies of the land-hungry Emperor (Horn of Africa, 4.1, 1981:35).

With time, looting and slavery became unprofitable and unreliable sources of income for the conquerors. Plunder discouraged economic production and the slave trade seriously arrested social reproduction. Hence it was necessary to keep the producer and extract his labour products for the occupation to continue. Other factors like European disapproval of slave trade and the saturation of the market 
discouraged this trade. It was at this juncture, during the first decade of this century, that another form of slavery called the gabbar system was instituted in the conquered areas. This does not mean, however, that looting and the slave trade were completely abandoned. It took several decades before trading in human beings was abolished. Naked plunder of the peasantry continued in one form or another up to the revolution of 1974 and even beyond.

\section{The gabbar system}

This system, except for some elements derived from the archaic Abyssinian feudal mode of production, diverged from the social formations of both the conquering and the conquered societies. The gabbar system was built on an extensive confiscation of land from the indigenous peoples, which was distributed among the Abyssinian royal families, the state, the Abyssinian nobility, the Orthodox Church, officers and soldiers who participated in the conquest and settled in the annexed territories. Hundreds of thousands of Abyssinian migrants who came to the south following the conquest were also allocated land. In fact, migration to the south was encouraged by the state to establish a strong naftanya (armed settler) force that could mitigate against any uprising by the subject peoples.

The economic and sociological implications of the imposed system were farreaching. In some of the territories, indigenous ruling families who submitted to Abyssinian rule without much resistance, and individuals who cooperated actively with the colonizers, were allowed to keep a third of their former holdings. But the vast majority of the inhabitants of these territories - particularly the Oromo and the Sidama peoples who were sedentary peasants - were turned into gabbars on their own lands (Map 2). Generally, gabbar means one who pays taxes or tributes. However, in its application to the conquered territories the term became synonymous with serfdom.

Serfdom as a socio-economic relationship is characterized by control more over the labour of the peasant than over the means of production-land-exercised by the landlord. Similarly in the allocation of land in the early stages of the gabbar system, what was of crucial importance was not often the size of land but the number of gabbars cultivating it. Consequently the number of gabbars allocated to each naftanya varied according to the naftanya's rank and social position in the political and administrative structure (Pankhurst, 1966:137). The gabbars were tied to the land and were not allowed to leave their villages or emigrate to other areas because this would abrogate their obligation to the naftanya (Pankhurst, 1966:140). Thus, through the gabbar system a patron-client relationship between the indigenous people and the settlers was instituted. The system gave the naftanya unlimited rights and privileges over the land, labour and labour-products of the gabbar. These rights and privileges were maintained through political coercion which the naftanya were able to exercise directly because of their position in the colonial structure of dominance.

The gabbars were obliged to provide goods and labour to their patrons, the quantity being determined by the patrons. In practice, the naftanya squeezed as much as he could out of his gabbars. Since they were excluded from the ownership of the land they toiled upon, the gabbars were forced to give up to seventy-five per cent of their harvest to the landowners. They were also obliged to perform various types of physical work for the naftanya like building houses, fences, looking after cattle, 


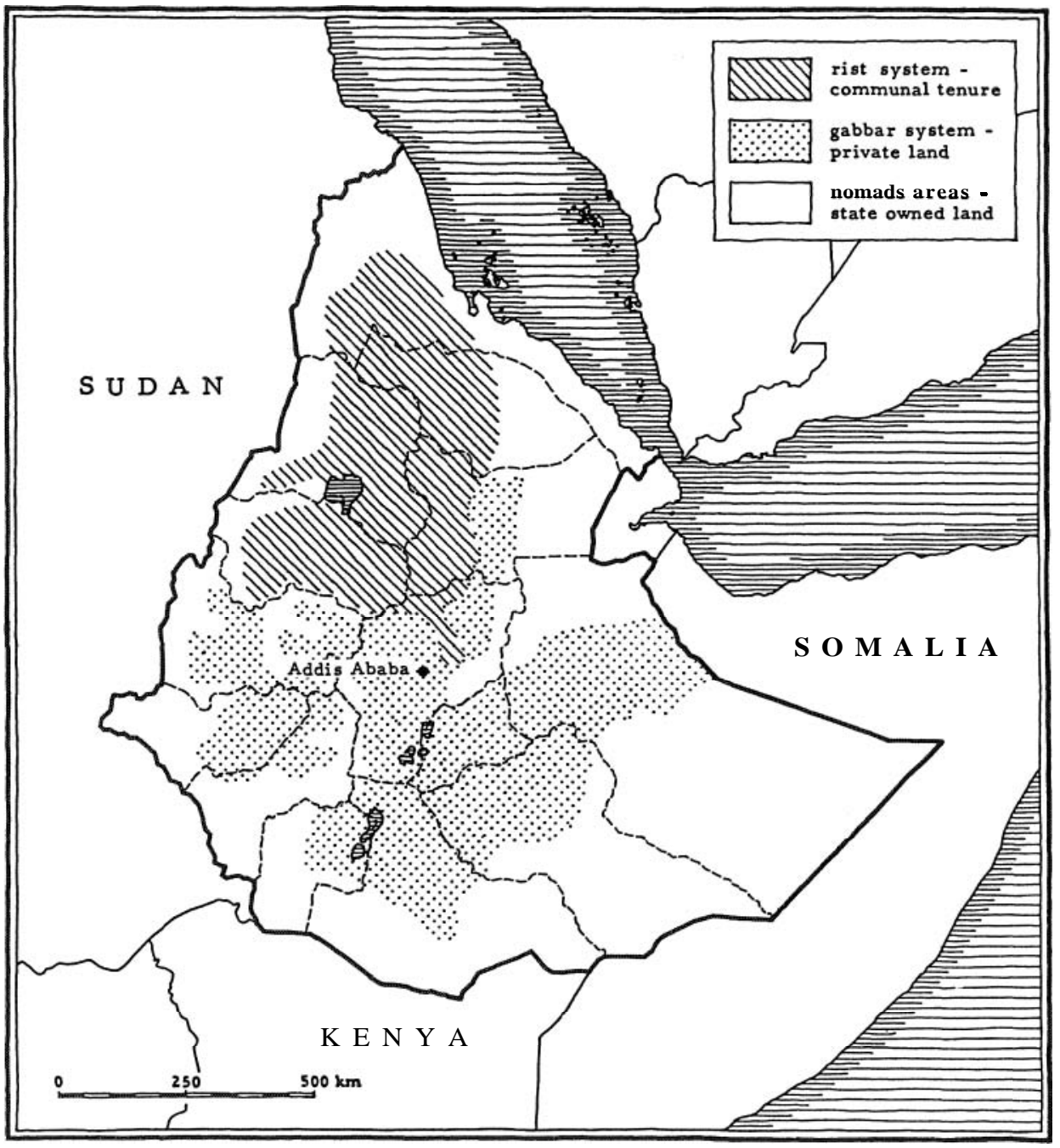

Adapted from S. Pausewang (1978).

going on errands or carrying necessities and following the naftanya when he was travelling, etc. The wives and the children of the gabbars fetched water and performed household duties for the families of the naftanya. The onerous burdens of the Oromo gabbar is portrayed in the graphic description of Asbe Hailu who in 1927 wrote that:

three times in a year he (gabbar) surrenders 15 quna (baskets) of ground flour to the melkegna (Abyssinian governor) tribute in honey, and a tenth of his produce to the state. No sooner the peasant had unloaded the tribute due to the melkegna that the latter 'congratulates' the peasant for having come just at the right time to be sent to the melkegna's qelad (land) somewhere beyond the Awash from where the peasant is supposed to bring a load of tef (grain). The toil-torn peasant supplicates, pleads and laments: 'Oh, sire, it is 
harvest time in our area and if I don't do the harvesting now, before the approaching rains, Sire I will be finished, evicted, uprooted! Oh, Sire! No heeding to his pleadings and lamentations. He must go to the qelad and collect the load of tef as the melkegna ordered! The peasant has no choice and he submits. Cursing, like the Biblical Eyob, his birthplace, i.e. his very existence, he takes to his heels in the direction of the Awash. At the qelad the inevitable happens. The mislene (the governor's representative)engages the peasant in the renovation of the melkegna's house on the qelad. That takes a good whole week's work. Only then does the peasant reach Addis Ababa with the load of tef, at Addis, another task, another order! Endless! The peasant now collects the whole lot of grain - the one from the Awash qelad, which he would have had grounded into flour, and the one he himself had brought in earlier - and stores them properly. While he does this he runs out of his own provisions and in the hope of keeping his belly full gorgeously moves after feast places - and comes back exhausted, sick and diseased.Like a sick old dog with his head resting on a heap of animal dung the peasant passes his last torturing and agonizing days below the fence of the melkegna's compund. When at last he dies, the melkegna's household servants carry the body on a stick and after a few scratchy digs they 'bury' him in a ditch. Oh! the donkey! No problem, somebody has helped himself to it as the peasant lay dying below the fence. A lady living nearby asks a lady of the melkegna's household: 'Sister, I saw a dead body leaving your household for burial today. Who could he possibly be? ( . . .) 'Don't mind him, Sister, reports the lady from the melkegna's household, "he is not human born, he is only agabbar" (cited in Addis Hiwet, 1975:20).

If land was transferred from one naftanya to another, either in the form of sale, inheritance or gift, the gabbars were transferred along with it just like any form of property. Even when his right over agabbar-land was terminated the naftanya could demand the service of his previous gabbars. This shows clearly that the naftanya or the Abyssinian settler in the conquered territories could utilize the gabbar labour nearly as fully as if they were his slaves but, unlike the slave owner, he had no responsibility to feed, clothe, or house his clients.

The settlers derived additional local labour from actual slaves who were acquired mainly as booty but also through purchase. The slaves had a marginal economic function and were kept primarily as domestics. Nevertheless, the settler communities kept a rather large slave population since the gabbar system, through its agricultural surplus, made their maintenance possible. Margery Perham (1969:232) noted that there were probably between 300,000and 500,000 slaves in the country as a whole on the eve of the Italian invasion in 1936.

Without doubt, the gabbar system permitted a very comfortable life for the Abyssinian migrants and settlers. Whether they were poor peasants, soldiers or "refugees" from the big famine of 1889-1892, they acquired a new status almost instantly on their arrival in the colonized territories. Whatever differences of status and interests they had back in Abyssinia, the settlers belonged to the same "class" and held the same interest in the conquered areas: keeping the indigenous peoples in subjugation and extracting surplus from them. Professor Knutsson has written that:

. . . to act the part of a poor Amhara (settler) would be of little avail since one of the basic ingredients in the Amhara ethnic status is its very connection with economic and political superiority (1969:98).

The settlers did not have to engage in agricultural work and, except for a minority who were employed in administration and trading, they devoted their time to idle leisure.

The sociological effects of the conquest on the indigenous societies were also very profound. With the superimposition of an alien landowning class, the social structure 
Table 2.1 The ethnic backgrounds of the populations of the major towns in the conquered regions of the south

\begin{tabular}{|c|c|c|c|c|c|}
\hline Province & Town/city & $\begin{array}{l}\text { Abyssinians } \\
\text { (mainly } \\
\text { Amhara) \% }\end{array}$ & $\begin{array}{c}\text { Indigenous } \\
\text { population } \\
\%\end{array}$ & $\begin{array}{c}\text { Others } \\
\%\end{array}$ & $\begin{array}{c}\text { Total } \\
\%\end{array}$ \\
\hline \multirow[t]{2}{*}{ Arsi } & Assala & 79.6 & 11.1 & 9.3 & 100.0 \\
\hline & Robe & 52.8 & 46.5 & 0.7 & 100.0 \\
\hline$"$ & Ticho & 85.9 & 8.7 & 5.4 & 100.0 \\
\hline \multirow{2}{*}{ Bale } & Dodola & 71.3 & 22.6 & 16.1 & 100.0 \\
\hline & Gobba & 84.5 & 11.1 & 4.4 & 100.0 \\
\hline$"$ & Goro & 67.6 & 31.9 & 4.5 & 100.0 \\
\hline Gemu Gofa & Arba-Minch & 59.0 & 36.6 & 4.4 & 100.0 \\
\hline \multirow{3}{*}{ Hararge } & Dire-Dawa & 52.3 & 20.5 & 27.2 & 100.0 \\
\hline & Harar & 71.0 & 26.0 & 3.0 & 100.0 \\
\hline & Asebe Teferi & 72.8 & 22.0 & 5.2 & 100.0 \\
\hline \multirow[t]{2}{*}{ Ilubabor } & Gore & 33.2 & 60.2 & 6.6 & 100.0 \\
\hline & Mattu & 34.5 & 58.1 & 7.4 & 100.0 \\
\hline \multirow{2}{*}{ Kaffa } & Jimma & 35.6 & 40.4 & 24.0 & 100.0 \\
\hline & Jinka & 79.6 & 16.4 & 4.0 & 100.0 \\
\hline \multirow[t]{2}{*}{ Showa } & Adama & & & & \\
\hline & (Nazreth) & $\begin{array}{l}71.0 \\
532\end{array}$ & $\begin{array}{l}17.4 \\
42.5\end{array}$ & $\begin{array}{r}11.6 \\
43\end{array}$ & $\begin{array}{l}100.0 \\
100.0\end{array}$ \\
\hline \multirow[t]{3}{*}{ ' } & Bishoftu & & & & \\
\hline & (Debrezeit) & 61.2 & 29.9 & 9.9 & 100.0 \\
\hline & Hosaena & 68.9 & 21.0 & 10.1 & 100.0 \\
\hline$"$ & Shashemene & 53.8 & 14.0 & 32.2 & 100.0 \\
\hline \multirow{3}{*}{ Sidamo } & $\begin{array}{l}\text { Awasa } \\
\text { Kibre-Mengist }\end{array}$ & 65.5 & 32.0 & 2.5 & 100.0 \\
\hline & nute-iviengis & 64.1 & 26.1 & 9.8 & 100.0 \\
\hline & Yirgalem & 68.0 & 10.4 & 21.6 & 100.0 \\
\hline \multirow[t]{3}{*}{ Wollega } & Dembi Dollo & 19.5 & 78.6 & 1.9 & 100.0 \\
\hline & Gimbi & 17.5 & 79.8 & 3.7 & 100.0 \\
\hline & Nakamte & 26.2 & 72.0 & 1.8 & 100.0 \\
\hline
\end{tabular}

Source: Adapted from Statistical Bulletin, No. 16. Analysis of Demographic Data of Urban Areas covered during Urban Survey, Second Round, 1969-1970. Central Statistical Office, Addis Ababa, Dec. 1977: 81-87.

of the conquered territories was altered. The political institutions of the indigenous peoples were replaced and previous rulers or chiefs were killed, as in Kaffa, Walayita and Arsi, or were demoted and turned into balabats or go-between between the colonial administration and the people at the local level. The existing social differentiation in the societies of the conquered territories was reduced to a minimum by the confiscation of land and property and the abolition of indigenous institutions. In general the relations between the colonists or settlers and the indigenous peoples was a relation between two groups who occupied different positions in the colonial social structure.

The indigenous peoples and their naftanya overlords were often separated by place and pattern of settlements. The naftanya lived generally in ketemas which were fortified towns or colons. Menelik built $\mathbf{3 7}$ such towns in the conquered areas of the south between 1887 and 1910 (Teshome, 1982:208). These ketemas, which were almost always located on a hill top for the purpose of defence against the local 
population, dotted the conquered territories and functioned as military administrative centres. The typical ketema contained the office of the governor, a prison house, an Orthodox church and later an elementary school, some shops selling imported goods, and several brothels and tej bets (bars for the sale of local drinks) where the male naftanyas spent most of their time when they were not in the countryside collecting dues and controlling the indigenous population. Initially, the inhabitants of the ketemas were mainly military, police and administrative personnel, their families and their servants who came from the conquered groups. Many of the naftanya chose to live in the ketemas rather than on "their" lands for reasons of comfort and safety (Bjerén, 1985:87). The ketemas were and still remain centres from which the system of oppression is maintained effectively over the conquered areas. The inhabitants of these towns produced very little but consumed a disproportionately large part of the products of the subject peoples. Gabbar labour was used to build the ketemas and to construct and maintain the roads and bridges linking them.

It is interesting to note that, 80 or 100 years after their foundation, the demographic composition of these towns remain much the same. As the figures in Table 2.1 show, the large majority of the urban population in the provinces of Arsi, Bale, Gemu Gofa, Hararge, Sidamo and Showa are still Amhara, most of whom are descendants of the original naftanya settlers. Wollega, which was less affected by the conquest and colonization, has fewer Amharas even in its major towns. There is a very dramatic change today even in the demographic structure of Wollega as the Province is severely affected by the Dergue's resettlement policy which brought hundreds of thousands of Amharas and Tigrayans to the south. Living in the rural areas, the indigenous peoples lacked any kind of modern services. The educational and health facilities that were available were located in the towns and catered primarily to the needs of the naftanya.

The state, which was the biggest landowner in the conquered areas, collected not only gibr (taxes) but during the first 3-4 decades of colonization also demanded hudad (labour service) from the peasantry. Thus, up to the middle of the 1940s, every gabbar family worked on state land, carried the produce to the state granaries, built court-houses and prisons where gabbars who failed to fulfil their onerous obligations to the naftanyas and the state were tried and detained.

The peasantry paid a variety of taxes. Education tax was collected from the gabbars although there were few schools in their areas. Even when schools were built in these areas, the children of the indigenous peoples were hindered by language and economic problems from using the opportunities. Consequently, in some of the southern provinces, children born to indigenous families constituted only a tiny minority in the schools. A survey conducted in 1959-60 indicated that the Amhara, who constituted only about 15 per cent of the total population, accounted for 55 per cent of all the students in Ethiopia's secondary schools and colleges (Levine, 1965:249). During the 1970s students who come from indigenous backgrounds in the conquered areas constituted less than 10 per cent of the university enrolment. Although the Abyssinians were less than 30 per cent of the population about 90 per cent of the places in the university were occupied by students of Abyssinian (Amhara-Tigre) origin. Even when taking the country as a whole the naftanya, because of the socio-economic advantages they enjoyed, were able to make more use of educational opportunities than any other group. Consequently, the majority of 
the educated elite in Ethiopia comes from this group. By virtue of their educational background and their political and social positions they occupy the most important posts in the state apparatus.

The gabbars also paid health tax although only very few of them ever saw a clinic or a doctor. The indigenous peoples were either Muslim or they followed other nonChristian religious beliefs. However, they were forced to build churches and pay tithe for the maintenance of clergy that served mainly the settler communities. The ground-work laid by Menelik was built upon by his followers. During the long reign of Haile Selassie the patron-client relationship between the naftanya and the indigenous peoples remained intact. But the introduction of capitalist agriculture in the 1960s brought about some changes in these relations. From the 1960s onwards the land security of the gabbars deteriorated rapidly and, in areas where development was introduced, they became victims of large-scale eviction (Pausewang, 1978: 30-31; Stbhl, 1974). State-owned agricultural schemes and development projects backed by international aid displaced peasants in thousands during the last 10 years of Haile Selassie's regime.

Education and travel, and above all profits from commercial farming, encouraged the landowning class and the bourgeoisie to embark on large-scale farming. Thousands of gabbars were evicted and their huts and property levelled by bulldozers and tractors. The government leased or gave freely vast tracts of land to multi-national agribusiness and tens of thousands of pastoralists were displaced from their traditional grazing and watering areas. The expansion of capitalist agriculture directly threatened the already precarious existence of the conquered and oppressed subject peoples. The evicted gabbars became either wage-labourers on the commercial farms or migrated to the urban areas to join the ranks of the lumpen proletariats in the shanty-towns. The pastoralists and agro-pastoralists, whose grazing lands were taken over by commercial farms, moved to drier and less hospitable zones where their stocks diminished rapidly (Bondestam, 1974). In the famine which followed the Ethiopian drought of 1972-74, an estimated 200,000 peasants and pastoralists lost their lives while the commercial farmers exported agricultural products. Displaced Oromo and Afar pastoralists in the conquered territories accounted for the majority of those who perished due to the famine or fled to urban areas in search of a means of livelihood.

\section{Cultural domination and oppression}

Every imperialistic conquest has presented itself as a vehicle of progressinspired by a 'civilizing mission'. But this has sometimes turned into what sociologists call "ethnocide" whereby the cultural indentity of the conquered communities are simply denied and supplanted by that of the conquerors (Mertens, 1981: 225-226). This was one of the major characteristics of the Abyssinian conquest and colonization since:

bearing the proud motto 'conquering Lion of Judah' . . . Menelik was as emphatic as his European counterparts in emphasing his sacred civilizing mission to impart the benefits of Christian rule to his heathen subjects (Lewis, 1983:3).

The "benefits" of this "Christian rule" involved the imposition of Amhara culture and language on the other peoples. The contradiction in this imposition was not that the conquered peoples were taught the Amharic language or accepted the culture of 


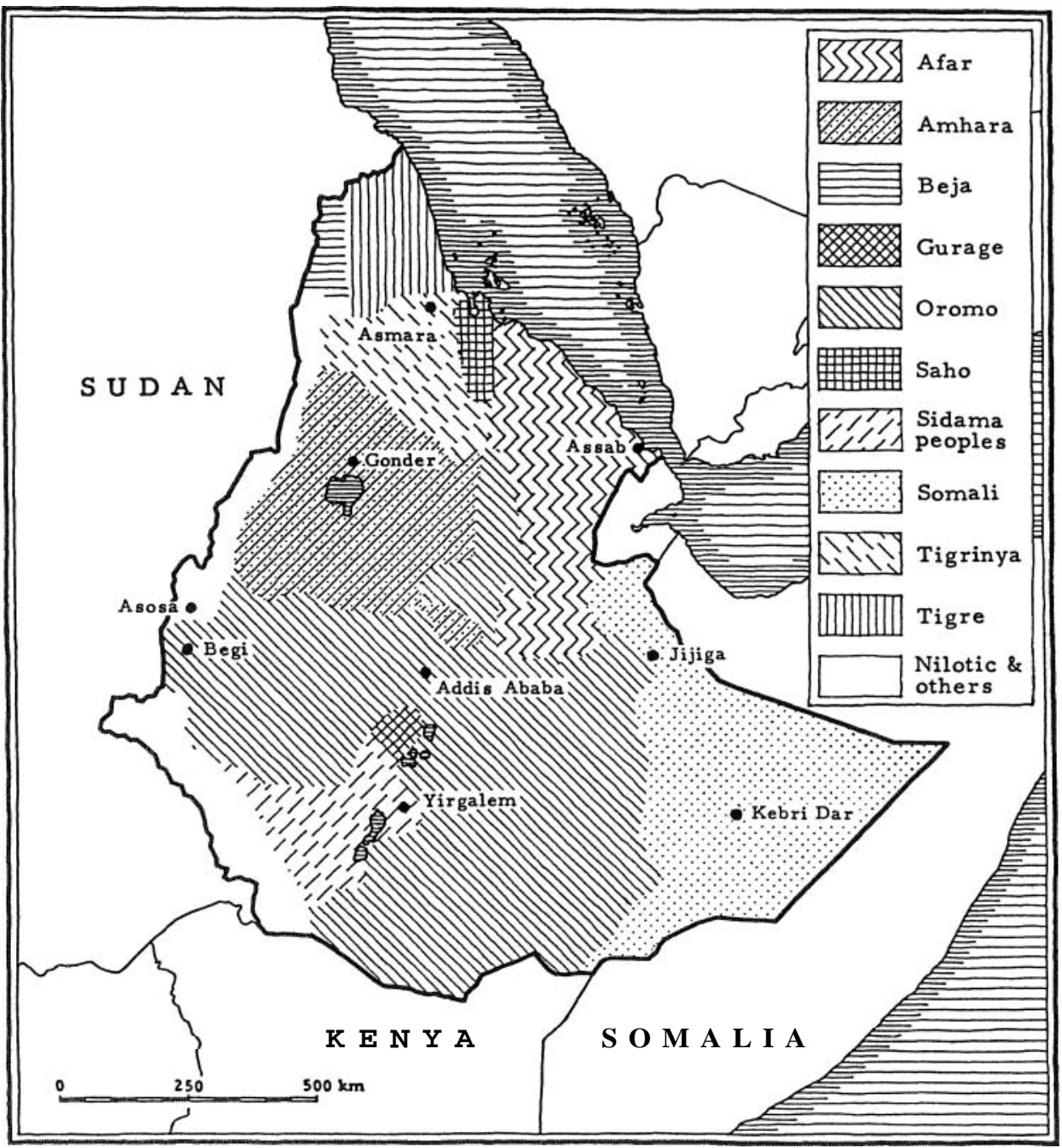

the conquerors. The problem was, and still is, that the imposition of the Amhara culture and language or Amharization, as it is commonly called by scholars, prevented indigenous cultures and languages from developing. Joseph Tubiana (1983:27) has suggested that language is the bearer of the values of its speakers and that it carries the imprints of their varying circumstances, their history and distinct identities. Hence, when a state supresses a language it attacks the very culture of the community that uses it. This was what was attempted in Ethiopia by the various regimes including the present one. The primary objective of the Arnharization drive was (is) the expansion of Arnharic at the cost of other languages. Amharic was imposed as the national language and the use of indigenous languages was (are) 
considered as inferior to the national language (cf. Knutsson, 1969:96). Above all, their use for preaching, teaching and administrative purposes was forbidden. Dr. Paul Baxter wrote,

... it was not permissible to publish, preach, teach or broadcast in . . . Oromo. In court or before an official an Oromo had to speak Amharic or use an interpreter. Even a case between two Oromo before an Oromo-speaking magistrate had to be heard in Arnharic. I sat through a mission church service in which the preacher and all the congregation were Oromo but the sermon, as well as the service, was given in Amharic, which few of the congregation understood at all, and then translated into Oromo. To have preached in Oromo would have resulted in the preacher being fired or imprisoned (1983:137).

Thus the languages of the conquered peoples, even when spoken by the majority of the population (Map 3), are condemned to remain non-literate and underdeveloped. Wherever and whenever there were chances for education the children of the conquered areas had to start their primary school studies in Amharic - a language which was entirely different from their own. Passing an examination in the Amharic language was compulsory for further education, and non-Amhara children with passing grades in the sciences were hindered from entering higher education. This practice is not only oppressive but is pedagogically absurd because English, not Amharic, is the medium of instruction in the higher levels. Baxter (1983:137) has succinctly indicated the absurdity of this practice when he wrote: "It is as if every English child had to use Russian in primary school and switch to Turkish for secondary school".

The disadvantages of the imposition of Amharic as a national language were also felt by the conquered peoples in other aspects. Language became a barrier to the acquisition of jobs in the private and public sectors and hindered social mobility in the colonial social setting. Lack of proficiency in the Amharic language was used as an excuse for keeping the Oromo, Somali and Sidama away from government posts and from sharing in political decisions. The state owned mass media, ignoring the non-Amhara peoples, worked almost entirely in Amharic ${ }^{6}$.

\section{Religion: means of exploitation and source of contradictions}

The suppression of indigenous religions, rather than the conversion of the population to their own faith, was the major orientation of the settlers particularly before the 1960s. The Abyssinians are of the Coptic Christian faith whereas the peoples of the conquered territories were either Muslims or followed local religions. Following the conquest, churches were built on sites of indigenous shrines and the religions of the conquered peoples were discouraged. The Coptic Church was given large tracts of land with gabbars on it. In some places a single church owned as much as 5000 hectares of the best land in the community (Braukamper cited in Bakke, 1986:124). In spite of the fact that the majority of the conquered peoples were Muslims, not a single hectare of land was granted to the mosques or to the Muslim priests. Part of the land given to the church was allotted to the clergy as private property, and as Bakke has rightly observed:

This made the priests far wealthier in these areas than were their colleagues in the north. While the priest in the north had been one of the people, in the incorporated areas he became one of the nobility and upper class (1986:124). 
The general attitude of the settlers toward the religions of the conquered peoples was full of contradictions and paradoxes. They discouraged and suppressed the indigenous religions. However, their efforts to convert their subjects were not concerted. Sporadic forced mass baptisms were carried out, but there was no organized endeavour to bring their religion to the indigenous inhabitants of the annexed territories. The vast majority of the southern peoples however, resisted, any attempt to convert them to the Coptic faith and embraced Islam en masse because as Trimingham (1976:101) stated, "it was the religion hostile to that of the Amharic race who lorded it over them". This added another important dimension to cleavages that separated the indigenous peoples and the settlers.

The failure of their half-hearted attempts to Christianize the indigenous peoples did not much bother the priestly landlords because it was the craving for land and not religious conviction which had brought them there. In addition:

The conversion of incorporated peoples was not really in the best interest of the Ahmara. They were stronger as long as they could monopolize Christianity without making this an instrument for others to become equal (Bakke, 1986:125).

Religious differences allowed the exploitation of those "outside" the "sanctified" universe. The non-Christian inhabitants of the annexed regions were mainly regarded by their Abyssinian overlords as aramant (infidels or pagans) and therefore "outsiders" whom the "insiders" could victimize without religious remorse or legal consequences.

The Christian religion was an instrument for the concentration of privileges and political power in the hand of the Abyssinians, mainly the Amhara from Showa. Christianity was a state religion and those who shared in the power of state were preferably those who were born into it. Thus the non-Christian inhabitants of the south were kept outside the state apparatus and the politics of the Empire. During the reign of Haile Selassie the people of the conquered areas, particularly the non-Christian section which constituted about half the country's population, lacked any sort of representation in the central government (cf. Clapham, 1969). And, as will be shown later, the situation remains the same even under the present regime.

\section{Resistance and Rebellions}

Resistance implies a collective or individual act against the presence of an alien political power with the aim of liberating a territory and a people from its domination. The peoples of southern Ethiopia did not accept the exploitative relationship with the settlers and the state which the settlers represented, and resisted it from the very beginning. The resistance was sometimes open and violent, but often it was hidden and silent. When open, the revolts were mainly spontaneous and limited to one area at a time.

It is useful to cite some of the major uprisings of the larger nations and nationalities as they are the forerunners of the current liberation movements in the Horn of Africa. Some of the present conflictsin Ethiopia are direct continuations of previous spontaneous revolts. 


\section{The Oromo resistance}

The Oromo are numerically the largest nation in the Horn of Africa. In Ethiopia alone they constitute about 50 per cent of the total population. There are more than 200,000 Oromos in northeast Kenya. Like most peoples in Africa the Oromo were divided by colonial boundaries during the Scramble for Africa. The subjugation of Oromoland started with the annexation of Wallo in the north in 1876, and was completed with the conquest of Borana in the south in 1899. The Oromo fiercely resisted the occupation and in some regions like Arsi and Bale it took nearly a decade and series of major battles before they submitted to Amhara rule (Abas Haji, 1982; Darkwak, 1978). In fact the decisive factor in the victory of the Amhara over the Oromo was the modern European weaponry which Menelik was able to import and deploy against them.

Oromoland, or Oromia ${ }^{7}$, covers an area of about four to five hundred thousand square kilometres ${ }^{8}$ (cf. Map 3). It is endowed with fertile soil, mineral and water resources, woodlands and abundant pastures. It is rich in livestock and wild game. As Oromia is the most fertile spot in the whole of northeast Africa and the source of all the important rivers in the region, it had always had the coveteous attention of its neighbours. The Abyssinians in particular had a long history of attempts to conquer the Oromo and their age-old dream became a reality with the acquisition of modern weapons from the European powers. The Oromo, as David and Marina Ottaway (1981:132) have remarked, "never derived any advantage from being Ethiopian subjects".

\section{The Gada society}

Before the conquest, most Oromo were governed by the gada. Gada refers to the Oromo social formation. It pervaded every sphere of social life and the nation was based upon it (Legesse, 1973; Knutsson, 1967; Mohammed Hassan, 1983; Bulcha, 1984). The gada organized society in a unique generation system with clearly defined social functions. The whole system evolved around an egalitarian distribution of authority and power. It guaranteed the democratic participation of all male members of the society in matters of public life.

The system institutionalized a regular transfer of social roles, political power and social status from one generation to the next in an eight-year cycle. Democratic elections of leaders who filled the different offices were conducted within each grade at local, regional and national levels. Social and religious obligations and even the behaviour patterns of individuals were organized through their place in the system. Gada was also related directly to the economic production of society and it regulated the allocation of resources to different social functions and communal tasks without discrimination. It did not allow appropriation of surplus by a specific group or category in society. Although kingdoms and monarchical institutions were established in regions such as Gibe long before the conquest, Gada was the basis for social life and culture, and the guiding principle of religious and social ideology, all over Oromoland. The gada democratic values and attitudes were strongly reflected even in the rule of the most centralized Oromo states. The socio-economic system which the Abyssinians imposed upon the Oromo and others was the antithesis of the gada system. The Abyssinian system was feudal, authoritarian and hierarchical. Political power, social prestige and privileges were bestowed or inherited. 
Because of its size and wealth, much of the war of conquest was fought on Oromo territory. The Oromo, unlike the other colonized peoples such as the Somali and the Afar, are peasants. Therefore, the gabbar system which, in contrast to the gada system, allowed appropriation of surplus was imposed mainly upon them. Being the largest nation in the empire, the main target of the Amharization policy were the Oromo people. Arnharic names were substituted for Oromo place names*. Oromo religious practices were discouraged or forbidden. The Oromo language was outlawed and Oromo history was suppressed and barred from being recorded or taught. As Pausewang (1978:107) has put it "The Oromo were forced to accept the authority of the naftanya and had to learn the twin deeds of deference and assimilation". The Oromo peasants had to demonstrate their submission and servility before their landlords in order to survive. However, Pausewang adds that the Oromo hated the naftanya and that, while forced to be submissive, they were always ready for revenge, and were full of explosive force. Oppression such as that imposed upon the Oromo people creates a natural desire for revenge.

The desire for revenge was kept alive by the ruthless measures used by the naftanya and their government wherever the indigenous population actively resisted the crude colonial exploitation and subjugation. The Oromo often talk of what they call kao or the "great resurrection" which will herald the 'departure' of the oppressor $^{\mathrm{g}}$. The desire for $k a o$ and defiance against oppression pervades their songs and tales (Triulzi, 1980; Knutsson, 1969:197-98). Such feelings were kept alive by the arrogance of the naftanya which continually reminded the Oromo of the atrocities committed during and after the conquest. Regarding the arrogance of the naftanya and their government Paul Baxter has written: “ . . . Amhara colonization is aggravated by such acts as the naming of the only secondary school in Arussi Province after Ras Darge who is bitterly remembered for his brutal conquest of the Arussi highlands" (1983:140). In addition to the institutionalized reminders of the brutal facts of conquest and colonization the naftanya in their conversation among themselves and with others were fond of making derogatory jokes about the colonized peoples.

Naturally this situation has led to deep and persistent contradictions between these peoples and the naftanya at all levels. The chasm between the Amhara and the Oromo, the majority of whom are Muslims, is so wide that very few succeed in crossing it. As Baxter (1983:141) has indicated, even those individuals who crossed the class and cultural barriers and became rich or gained important positions maintained mainly formal, uneasy and courteous relations with their Arnhara counterparts. Even between the Amhara and the Oromo families who were converted to Christianity marriage was very limited and seems to have decreased since the revolution.

What is said above explains the reasons for the failure of Ethiopia to become an integrated and united state and the proliferation of conflicts and resistance movements. The Oromo resistance was characterized not only by covert defiance expressed in songs and tales but was also manifested in numerous uprisings. Most of these open resistance movements were mass based and were led by peasants. But there were also uprisings which had Clite characteristics or were led by Clites. Most of the uprisings were local and of limited duration. But some of them had a wider spatial

\footnotetext{
* Thus Finfinne, Ambo, Bushoftu and Adama were given the Amharic names of Addis Ababa, Hagerehi-
} wot, Debrezeit and Nazreth. 
and temporal span and have dove-tailed into the Oromo Liberation Front (OLF) which is currently active both inside and outside Ethiopia.

The revolts of the northern Oromo

The first significant revolt in Oromo areas took place in 1928 among the Raya in the north. The revolt was ignited by excessive taxation and corrupt administration. The Raya Oromo defeated the government forces in a series of clashesin the beginning of the conflict. But contact with the other parts of the country was rendered impossible because of poor communication and the rising failed to achieve any tangible results (Gilkes, 1975:208). The failure did not, however, result in quiescence and the Raya Oromo revolted again in 1935-36, 1943 and 1948.

\section{The Western Oromo Confederation}

Another important movement with nationalistic overtones was the Western Oromo Confederation which surfaced in the west in 1936. The confederation was an Clite based movement and was formed by the descendant of the pre-conquest $\boldsymbol{M} \boldsymbol{b} \boldsymbol{i}$ (kings) of the Macha Oromo and their chiefs, under the leadership of Habetemariam Kumsa - a member of the Bakare family that had ruled parts of eastern Wollega since the 1840s. The leaders of the confederation organized the different sections of state includingforeign affairs and sent a delegation to the British Consul at Gambella with a letter to be sent to the British government and the League of Nations to seek recognition. In their letters they conveyed the historical background to the declaration and emphasized that the Oromo have never been subjects of the Kings of Abyssinia but were an independent people. They added that even after the conquest the Western Oromo did not completely $\operatorname{lose}^{10}$ their freedom (Gilkes, 1975; Melbaa, 1980).

The confederation was not, however, recognized. Furthermore, the movement was brought to an end by the Italian occupation of Ethiopia between 1936 and 1941 . Neverthless, the uprising showed once again the Oromo desire for self-determination. As Patrick Gilkes has clearly stated:

It is clear from this that the western Oromo had agreed among themselves that they did not want any further Amhara control. While this may have been precipitated by the collapse of the Empire it was a feeling that had deep roots. It cannot be explained by bad government from the centre, as Wollega had been virtually independent of Shoan (Amhara) control. It is explicable only in terms of Oromo nationalist feeling . . . The attempt at independence was a failure due to the British refusal to support it and the Italian advance (1975:213).

When the Italians were defeated in 1941 Haile Selassie was restored by the British. The Oromo resisted the restoration of Haile Selassie's government without success (Greenfield, 1965:273). The resistance continued after the war but organized uprisings and movements began only in the middle of the 1960s. Of these, the MachaTulama Association and the Bale Peasant uprising are most significant.

The Macha-Tulama Association

The Macha-Tulama Association was the first country-wide Oromo movement. The organization recruited its members from all regions and from every section of the 
Oromo society. Military officers and intellectuals played leading roles in the organizational work and the association registered several thousand members within a few years. Branches mushroomed all over the vast Oromo country. With its headquarters in Addis Ababa the organization dedicated itself to promoting Oromo selfidentity. Its declared objectives were the spreading of literacy, the building of schools and clinics, and the teaching of basic health care to the Oromo peasantry. Covertly the association worked for peaceful change in the oppressivesocio-political structure of the Ethiopian Empire and to bring about equality between the Amhara and the Oromo (Keller, 1981:542). It aimed for unity among the various conquered nationalities in the south, and representatives of the Walayita, Hadiya, etc. were invited to attend" its general meetings. These were held in the capital and in the provinces, and were attended by thousands of members.

The association, because of its fast growing popularity, was seen as a threat to the imperial government and various attempts were made to frustrate its activities. But since the association conducted its meetings and activities in accordance with the law of the empire, a reason had to be found to take any measures againstit. When abomb allegedly planted by a provocateur hired by the security exploded in a cinema in Addis Ababa, the regime immediately held the association responsible. Most of its leaders were detained; some were given long prison terms and some were sentenced to death. The association was banned but its activities did not cease completely, as some sections in urban areas resorted to underground activities and others left the country to organize resistance from abroad.

\section{The Bale peasant armed struggle}

The Bale peasant rebellion, which lasted from 1963 to 1970, was the first persistent and well-organized armed uprising the Oromo staged against the Amhara administration in the south. Actual fighting broke out in 1964 and, by the end of 1965, virtually the whole central area of the large province of Bale was rebel-controlled except for two garisson towns. The rebels employed classic guerrilla tactics (Gilkes, 1975:214). They carried out raids against police and army posts from bases hidden in the heavily forested mountains. They managed to cut supply lines and isolated army units from their headquarters. The government committed large units of the regular army to the fighting and declared a state of emergency in the whole province. But the government forces suffered continued losses and at the end of 1967 a whole army division and a large militia force were tied down by the rebels. British army engineers were brought in to help solve communication problems. Extensive air power was deployed and American experts were engaged in improving the precision of the bombing planes (Gilkes,1975:21b). These efforts, however, did not change the situation very much since the period $1968-69$ was marked by a virtual stalemate between the forces.

In 1969, a military coup in neighbouring Somalia brought about a change in the situation since the new government cut the supply lines to the guerrilla and even imprisoned some of their representatives. When the arms supply began to drop off some of the leaders were forced to negotiate with the Ethiopian government, and some of the guerrillas were finally persuaded to lay down their arms. However, the movement was not liquidated. 


\section{Resistance in the Ogaden}

Uprisings in the conquered territories were not limited to the Oromo but surfaced also among other nationalities like the Sidama and the Walayita. The conflict, however, has been most acute in the Ogaden where successive Ethiopian regimes have failed to pacify the inhabitants. The Ogaden Somali, being mainly nomads, were affected only marginally by the policy of Amharization. Their contacts with the Amhara adminstration were very limited and often involved only irregular tax collection which usually "took the form of official raids and ambushes in waterholes and market places, from where men and animals were carried off' (Markakis, 1984:554).

The imposition of colonial rule affected the pastoral Somali in several ways. Their land was divided between four powers: the French, the British, the Italians and the Abyssinians who claimed the Ogaden semi-desert. The colonial division disrupted the pastoral economy by interrupting the transhumance cycle of pasturing and watering livestock. Consequently, the reaction of the Ogaden Somalis against the occupation of their territory by alien forces was intense and persistent.

The Somali resistance in the Ogaden finds its roots in the legendary anti-colonial exploits of Siyyad Muhammad Abdullah Hassan who fought the British, Italian and Abyssinian colonialists between 1895 and 1920. Lasting over 20 years the resistance launched by Muhammed Abdullah Hassan, nicknamed the "Mad Mullah" by the British, is one of the earliest and longest freedom struggles initiated against colonial rule in the Horn or elsewhere in Africa. During those years the Siyyad fought a series of wars against the British, Italian and Ethiopian forces who often staged joint expeditions against him (Eshete, 1984:305-306, Kakwenzaire, 1985:36). The tenacious efforts of Siyyad Muhammad to unite the Somali and rid his land of foreign rule failed because his nomadic forces were no match for the forces of the three colonial powers. The Ogaden Somali revolted several times but were brutally repressed by the army which most of the time was charged with the administration of the province.

Resistance against Ethiopian rule was, however, intensified following the independence of Somalia in the 1960s. The Somali regime immediately declared its commitment to the freedom of their kinsmen in the neighbouring countries, a policy which has been followed ever since. In the meantime, Ethiopia and Somalia have been involved in open conflict several times.

The involvement of Somalia has often confused the cause of the people in the Ogaden as a border problem between two states. The invasion of the Ogaden by the Somali army in 1977-78 has done much damage to the cause of these people and the neighbouring Oromo because it has provided the Ethiopian military regime with grounds for equating the resistance of these subjugated nationalities with Somali territorial aggression, thus denying them sympathy in international opinion. However, the conflict between the Western Somali Liberation Front (WSLF) and the Ethiopian government has persisted for almost two decades now and has produced, together with the war between Somalia and Ethiopia, about half a million refugees and hundreds of thousands of internally displaced persons.

\section{Contradictions in Abyssinia proper}

Conflicts were not confined entirely to the conquered areas but also took place, if on a limited scale and less often, in the Abyssinian region. Both inter-class and intra- 
class contradictions produced social conflicts with significant consequences. Class contradiction which manifested itself in peasant rebellions was, however, less frequent than conflicts between the different ruling houses and feudal barons who contested over political power.

Contrary to the post-conquest practices in the southern provinces, land tenure in the north was communal and every family had rist (inalienable) rights to lands they cultivated. However, this does not mean that the peasantry were free from class exploitation since the nobility had gult (tax-collecting) rights over rist lands. Even if the exploitation exercised by gult holders was much less devastating than the gabbar exploitation it was severe enough to cause uprisings now and then.

\section{Rebellions in Tigray}

As we have mentioned before the Amhara and the Tigrayan people are commonly known as the Abyssinians, and the province of Tigre which was the seat of the old Abyssinian kingdom has been a centre of major conflict.

At the time of the formation of the Ethiopian Empire Yohannes IV of Tigray was the Paramount King of Abyssinia. Menelik II carried out the conquest of the southern provinces while he was his vasal. It was upon the death of Yohannes IV that Menelik became the Emperor of Ethiopia and moved the centre of political power to Addis Ababa in the annexed Oromo territory. The expansion of the empire and the transfer of the seat of state power from the north to the south reduced Tigray to a periphery causing dissatisfaction primarily among the Tigrayan nobility. However, the military might which Menelik built up with wealth acquired from the conquered areas in the south and southwest tipped the balance of power in his favour and rendered the northern feudal barons almost impotent. They accepted Menelik's superiority, if unwillingly, while he left them virtually independent to avoid confrontation.

Haile Selassie broke this tradition. After the war with the Italians (1936-1941) the pressure on the Tigrayan nobility was intensified as Ethiopia moved from a relatively decentralized, pre-capitalistic feudal empire to a more centralized absolutist state. This, as well as an inefficient and corrupt administration, aroused popular resentment against the government and culminated in the famous Wayane uprising of 1943. The Wayane desired to be independent of the centre and could only be suppressed after British bombers and military advisors were involved on the side of the regime (Gilkes, 1975:190). Haggai Erlich has argued that the suppression of the Wayane was the main watershed in the history of Tigray because the emperor was able to demilitarize the province and deprive its leading feudal houses of their source of independent power (1984:329). He also adds, however, that "Haile Selassie remained to the end respectful of Tigre's unique status in the empire". In fact Haile Selassie restored the feudal lords and gave them an autonomous status in local administration just because of the Wayane conflict.

The restoration of the feudal rulers, however, did not improve the lot of the Tigrayan masses. Few changes took place in the social and political life of the province. Unlike their counterparts in Showa, the Tigrayan nobility benefited only marginally from the conquest of the southern peoples and relatively few families from the province became naftanya in the south. Rapid deterioration of farmlands due to centuries of exploitation and fragmentation resulted in ever decreasing 
economic production and, ultimately, abject poverty. Peasant poverty was accentuated by feudal exploitation and exacerbated by cyclical drought, locust invasions and epidemics. The revolution of 1974 has not improved the conditions in Tigray and for more than a decade the province has been ravaged by a war between the Tigray People's Liberation Front (TPLF) and the military government in Addis Ababa. A devastating famine has caused the death of thousands of people and, together with the effects of the war, sent hundreds of thousands of Tigrayans into exile.

\section{Eritrea}

Since much has already been said by other writers (Habte Selassie, 1980; Davidson et.al., 1980; Sherman, 1980; Erlich, 1982) only a sketchy outline will be provided of the process that led to the formation of Eritrea as a geographical and political entity, and of the events that lie behind the armed conflict that has afflicted the Eritrean peoples over the last 20 years.

The land area of Eritrea is about 119,000 square kilometres and has a population of about 3.5 million (Habte Selassie, 1980:48). Its location along the Red Sea makes it strategically attractive and its coastal regions have changed hands between colonial rulers for a long time (Habte Selassie, 1980:49; Pool, 1983:178). The Eritrean society is composed of eight nationalities speaking different languages and adhering to two main religions: Christianity and Islam. The Christians live principally in the central highlands and share common ethnic, religious and cultural backgrounds with the people of Tigray to the south. The highlands of Eritrea and Tigray were, in fact, the centre of the ancient kingdom of Aksum and the cradle of Abyssinian culture. The majority of Eritreans are peasants and pastoralists. The peasantry is concentrated mainly in the highlands and the Muslim pastoralists inhabit the hot lowlands.

\section{The colonial experience}

Eritrea became a geographical and political entity during the colonial division of the Horn of Africa. While Menelik was busy conquering and annexing the Oromo and Sidama territories in the south, the Italians were expanding their colonial possessions into the Eritrean highlands from their coastal footholds which they acquired through a fraudulent purchase of the port of Assab in 1869. The colonization of Eritrea was completed in 1889 and Italian sovereignty over it recognized by Menelik in the treaty of Ucciali.

Italian colonial rule had essentially different consequences for the Eritrean peoples than Abyssinian rule had for the Oromo and Sidama peoples in the south. Even though the Italians imposed their own language and political culture on the Eritreans and carried out a certain degree of land confiscation, their rule was generally less exploitative. The Abyssinians exploited the south using slavery and the onerous gabbar system, while Italians exploited Eritrea through a market based capitalist economy, commercial farms and industrial development.

Italian rule came to an end in 1941 when Italy's forces were defeated in Africa by the allied British and Ethiopian forces. Eritrea became a British protectorate. During the war years Britain further built up Eritrean industry, primarily to meet its own war needs (Firebrace and Holland 1984:18). The result of Italian and British rule was, among other things, rapid urban growth and the development of a working 
class. According to Bereket Habte Selassie (1980:54) about 20 per cent of the Eritrean population was living in cities by 1940, giving Eritrea one of Africa's largest urban working classes in absolute as well as relative terms. Furthermore, the British rule led to a democratic political culture which was suppressed following the annexation by Ethiopia. These are perhaps some of the factors that account for the tenacity the Eritrean struggle for independence has shown over the last 20 years.

\section{Federation and annexation}

Eritrea was federated with Ethiopia in 1952 by the UN General Assembly. The UN federal act gave Eritrea an autonomous status with a parliament and government of its own in the field of domestic affairs. Matters of defence, finance, foreign and interstate trade and communications were to be under federal jurisdiction. The federation lasted only ten years because of the incompatibility between the relatively democratic institutions and political practices in Eritrea and the autocratic feudal government of Haile Selassie.

Haile Selassie banned Eritrean political parties and trade unions and imposed censorship on Eritrean newspapers. Tigrinya and Arabic, the two major languages, were supressed in official communications, public administration and education and were replaced by Amharic, the official language of imperial Ethiopia. The Eritrean Prime Minister, Tedla Bairu, resigned in protest against the violation of the articles of the UN Federal Act and direct intervention by Haile Selassie in Eritrean internal affairs (Habte Selassie, 1980:60; Firebrace and Holland, 1984:20). The Eritrean masses staged demonstrations and strikes in protest against the steps taken by Haile Selassie's government but these were broken up by the police. The Eritrean parliament was pressed to accept the dissolution of the federal arrangement and Eritrea was annexed in November 1962, thus becoming an ordinary province of the Ethiopian Empire.

\section{The Eritrean Liberation Movement.}

Protest against the dissolution of the federation and the subsequent annexation developed gradually into an armed struggle led by the Eritrean Liberation Front (ELF). Guerrilla activities staged by the ELF increased, at first primarily in the western lowlands. Repression of civilians suspected by the security forces for hiding rebels became frequent and harsh, causing large population movements across the border into the Sudan. By 1967, more than 30,000 Eritrean refugees had sought asylum in eastern Sudan. To date, about half a million Eritreans have left their country because of the conflict.

The Eritrean Liberation movement has undergone profound changes since its inception. The movement, which was initially an alliance of urban intellectuals and lowland nomads, has broadened its scope and encompassed the whole of the Eritrean society. This growth has also brought with it internal tensions and conflicts, leading to the formation of competing nationalist organizations. The Eritrean Peoples Liberation Front (EPLF), which was formed in 1970 by groups which broke away from the ELF, is today the largest and most powerful force in the area.

Irrespective of the internal conflicts which have at times flamed into armed confrontation and created obstacles to independence, the common experience under 
foreign rule and the long period of resistance have created an Eritrean identity felt in all sectors of that society. The liberation efforts are supported by Eritreans from all walks of life, and this makes the Eritrean struggle very powerful.

The Eritrean struggle has had far-reaching consequences for the economic development and politics of the region as a whole. In the late 1960s and early 1970s the Eritrean movement, together with the Oromo uprising in Bale, was a source of inspiration for the student movement in the capital. The two movements also helped to weaken the feudal regime and contributed to the genesis of the momentous events of February 1974 that brought about the regime's fall (Halliday and Molyneux, 1981:156).

The tragedies of the Eritrean conflict are felt not only by the Eritrean peoples. Tens of thousands of young men forcibly conscripted in the south have become cannon-fodder in Eritrea. Hundreds of thousands of families, not only from Eritrea, have thus lost their bread-winners to this war. In order to raise funds for the war, the military government taxes the peasantry heavily and a long term mortgage is put on the coffee harvests of the Oromo and Sidama peasants to pay the billion-dollar arms bill the Dergue owes the Soviet Union. In short, the consequences of the Eritrean conflict are poverty, misery and underdevelopment in the whole region.

\section{Conclusions}

Like any other African country, today's Ethiopia is a colonial creation. The country took its shape only about a century ago through the conquest and annexation of independent territories and peoples by the Abyssinian kings, particularly Menelik II. The conquest was most violent and involved mass killings, destruction of property and looting. The indigenous peoples were captured and sold into slavery. The conquest, and the state structure subsequently built to incorporate the subjugated peoples, are among the major underlying causes of current conflicts in Ethiopia.

The Abyssinian dominance over the conquered peoples showed remarkable similarity with contemporary European colonial rule in Africa in its ramifications. Ketemas (colons) were established in the classical colonial fashion in these newly annexed territories. The naftanya, who were mainly the agents of the state, priests and businessmen resided in the ketemas more or less separated from the local people. Even ordinary settlers did not live on the land for reasons of safety and comfort.

The cleavages between the indigenous peoples and the Abyssinians were very wide and the contrasts very sharp indeed. The contrasts were/are cultural, religious, linguistic and even to some extent racial. The cleavages were articulated in the overlapping inequalities in political status, economic participation, educational opportunity and fundamental cultural and human rights. Like all colonial expansions the fundamental motive behind the Abyssinian conquest was economic. The Abyssinian state, its agents and even the ordinary settlers extracted the surplus and labour power of the indigenous peoples in a rather crude fashion. At first this was done by looting property and capturing and selling sections of the population into slavery. The next step was the confiscation of land which was distributed among the members of the nobility, the state and its agents, the Abyssinian Coptic Church and the settlers who came to the south in the wake of the conquest. The onerous gabbar system, by 
which not only land but those who cultivated it were allocated to the naftanya was imposed upon the conquered peoples who became gabbars (serfs) on their own lands. The system gave the naftanya unlimited power and privileges over the gabbars. The gabbar paid as much as three-fourths of their produce to the naftanya. What is more they were obliged to provide an extensive list of labour service to them.

In essence a naftanya was privileged to use his gabbars as if they were his slaves. In addition to their onerous obligations to the naftanya, the gabbars paid a variety of taxes to the state and the Coptic Christian Church to which the vast majority did not belong. The position of the naftanya in the colonial structure of dominance enabled them to directly exercise their privileges over the indigenous peoples.

The interdependence of the state and the naftanya made the position of the settlers in general very strong and the burden of the conquered peoples very heavy. The settlers depended upon the state for their positions and safety while the state relied upon them to administer, collect dues and control its subjects. Consequently grievances against the naftanya from the indigenous people were seldom given serious attention by the Emperor and his ministers.

The rifts between the Abyssinian minority and the conquered majority along the lines of culture, language and religion were as deep as the cleavagesin political rights and economic privileges. Under both Menelik II and Haile Selassie I little effort was made to abolish these inequalities and transform the empire into a heterogenous stable state. Rather, their policies intensified and perpetuated the contradictions. The Amhara language and the Christian religion were imposed upon the indigenous peoples and their own languages and cultures were designated inferior. Attempts were made to forcibly assimilate them through a policy often refered to as Amharization. Several methods were tried to implement Amharization. In the beginning forced mass baptisms were conducted to convert the subjects to the faith of their rulers. Local place-names were even substituted by Amharic names.

Churches were built on the sites of indigenous shrines and local religions were suppressed or discouraged. The use of indigenous languages in education, administration and the church were forbidden. With the passage of time more subtle channels such as the educational system were used to Amharize the subject peoples. Those who accepted the Amhara culture and religion and learned their language were favoured by the state over the rest.

However the policy of Amharization achieved very little success under the ancien régime. There were several reasons for this lack of success. Primarily the resistance of the indigenous populations was strong. In some areas they embraced Islam to confirm their difference from their rulers. Secondly, the naftanyas as a tiny minority were in no position to spread their language and culture to the indigenous majority. The state lacked not only resources but even the will to spread education to these peoples. Thirdly, the contradictions and paradoxes which characterized the attitude of the settlers was a significant hinder to a consistent implementation of the policy. Certainly Amharization was not always in the best interest of the naftanyas as it involved some share of power and privileges with non-Amhara groups. Hence, their endeavours to Amharize the indigenous peoples were unconcerted and half-hearted.

Thus society in imperial Ethiopia was an extreme form of what anthropologists call a plural society. Such a society is characterized by sharp cleavages between different population groups brought together within the same political unit (Kuper, 1980). Conflict rather than consensus marks the relations between its constituent groups. 
This has been also the case in Ethiopia. The life span of the Ethiopian empire state was full of uprisings among the conquered peoples. Even in the north there was significant resistance against the absolutist state under Haile Selassie. It was the cumulative effect of this resistance which, together with indigenous and exogenous conjunctural factors, brought about the Ethiopian revolution which we shall discuss in the following chapter. 


\section{Chapter 3 \\ The Ethiopian Revolution}

It was not only the oppressed masses who did not want to live in the old way, the exploiters were not able to live and rule in the old way (Lenin).

\section{Introduction}

The Ethiopian revolution of 1974 was brought about by an interplay of long- and short-term factors. As we have seen in the preceding chapter, Ethiopian society was rife with multiple contradictions which were directly linked to process of the formation of the empire. In the mid-1960s the cleavages began to deepen and conflicts were intensified. What is more, the archaic feudal order was in decline and, when the structural contradiction became acute in 1974, it crumbled without much resistance. Although the national opposition and the conflicts in Eritrea and Bale were the most visible evidence of political opposition in the 1960s and early 1970s, what most hastened the downfall of Haile Selassie's regime were the structural problems in the economy.

\section{Structural crisis}

When the revolution broke out the transition to capitalism in the Ethiopian Empire had only just begun. However, the few inroads that capitalism had made into Ethiopian society had already weakened the traditional bases of social and political power of the aristocracy. This transition, combined with protracted agrarian setbacks and crises, was forcing an ever growing proportion of the peasantry into destitution (Halliday and Molyneux, 1981:15). The material basis for the alliance between the commercial and bureaucratic bourgeoisie and the "modernized" small section of the feudo-bourgeois class that dominated the Ethiopian society on the eve of the revolution, was a cash-crop economy producing primarily coffee and oil-seeds for export to foreign countries. The economy was linked to the capitalist market in a dependent relationship under which the development of agricultural self-reliance and industry were not priorities. Eviction and the fall in domestic food production exacerbated rural poverty and drove masses of unemployed peasants into the urban centres. In these centres there were sporadic protests and demonstrations led by university and high school students.

\section{Conjunctural factors}

Among the immediate causes of the revolution were rises in commodity prices, a World Bank initiated educational programme and the outbreak of a devastating famine in the northern provinces. The rise in the world price of oil and the government's decision to raise gasoline prices by 50 per cent led to a strike among taxi-drivers which had unexpected results and was extended to a general strike. In 
addition, a teachers' strike in protest against a new educational policy paralyzed educational institutions throughout the Empire. When the army and the police forces were drawn into the wave, the members of the ancien régime were left to stand alone against the ever-rising tide of opposition. The ruling class was also divided by internal contradictions and was not in a position to form a united front to contain the growing opposition.

The most decisive conjunctural factor of the revolutionary uprising was the disastrous drought and subsequent famine which claimed the lives of more than 200,000 people. The callousness and irresponsibility which the regime showed in failing to provide relief to the drought victims provided the various opposition forces with a common cause, making the famine the main grave digger for Haile Selassie's government.

\section{The Contention for State Power}

While the feudal political structure was crumbling under the growing anger of the oppressed and dissatisfied sectors of the population, a major problem was facing the revolution. The problem was the lack of a leadership that could lead to the achievement of the aspirations manifested in the popular upsurge. The total absence of rights for political organization during the absolutist regime had prevented the formation of political parties. As well, the lack of industralization meant that the working class was small and the labour union movement in its rudimentary stages. Hence with the fall of Haile Selassie's government the political power at the centre was left for a divided civilian left and the military to occupy.

\section{The Military Council or the Dergue}

The Military Council or the Dergue which finally won the contest for power and came to succeed the ancien régime was originally called the Coordinating Committee of the Armed Forces, the Police and the National Guard. It had its origins in the protests staged by men in uniform all over the country to demand better pay and decent living conditions for themselves and their families. Hence, the origin of the Dergue lay in corporate interests and not political revolution. When it took power, it had no strategy or ideology for social and political change. The military's engagement in the process of change came only through pressure from a long process of mass demonstrations and criticisms from groups within the civilian left. The Dergue's experiments with two short-lived, bourgeois civilian governments of Endalkatchew Mekonnen and Michael Imru, both belonging to the high nobility, and its initial inclination to the idea of a constitutional monarchy clearly indicates the Dergue's hestitation to take political power at the outset of the revolution. The role of leadership was almost forced upon the Dergue as a group (there could be politically ambitious individuals amongst them) by the circumstances that obtained in 1974. But once the Dergue and particularly the hard core within it, were entrenched in its new position, it became reluctant to hand over political power to civilians. But the tenacious hold of the Dergue onto the imperial chair could not be explained wholly by the comforts and prestige derived from political power. The will to stay in 
power also seems to have emanated from the instinctual drive for survival. An Oromo saying goes: "If you hold a tiger by the tail you let it free at the risk of your life". The lack of democratic tradition in politics makes the exercise of state power a dangerous game in many of the African states. The Dergue has exercised political power ruthlessly and it is logical that it fears that the same power could be used against it if and when it loses control.

\section{The Dergue's social and political ideology}

As we have already indicated the Dergue had no strategy for social or political change at the beginning of its political career. Its adoption of socialism, which remained alien to its members until long after the revolution was a pragmatic move rather than a result of ideological conviction. The source of the previous regimes legitimacy was a Christian kingship which was traditionally accepted and ecclesiastically sanctioned source of authority. The Dergue lacked such a traditional source of authority and legitimacy. In addition, the section of the urban petty bourgeoisie that posed the greatest threat to the Dergue's authority professed socialism as its political ideology.

None of the members were schooled in Marxism and the socialist ideas which characterize their $\boldsymbol{a w a j}$ (proclamations) that were adopted through an alliance with one of the left civilian groups, the All Ethiopian Socialist Movement (MEISON). Through its organic alliance with it MEISON provided the Dergue with political cadres at all institutional levels and tutored some of its members in the rudimentary concepts of Marxism. Although the Dergue's adoption of Marxism as an ideology of the state was a pragmatic act which provided the regime with a political argument and enabled it to appropriate or, as Addis Hiwet (1984:36) saw it, plagiarize the ideological weapons of its main contestant, it turned to be more than a short-term manoeuvre for the conquest of the state power. Once the battle with the civilian left was won Marxist ideology was put to the service of guiding and justifying the extension of the regime's control over the society.

\section{The civilian left}

As we have indicated the most significant and visible opposition to the ancien régime and later to the Dergue between 1974-78 came from the students. The Ethiopian student movement had its roots in the events related to the abortive coup against Haile Selassie in 1960. At the time of the revolutionary upsurge in 1974 the movement had grown into a significant force commanding a large following among university and secondary school students throughout the empire and among Ethiopian students abroad. The students played important roles in the events that led to the revolution and were also active in the removal of landlords from the countryside and the formation of peasant and urban neighbourhood (kebele) associations.

However, the Ethiopian student movement was already experiencing a rupture when the revolution broke out. The rupture appeared first in the foreign wing of the movement and was articulated in the formation of two opposing factions ${ }^{1}$. The cleavage was carried into the main body of the student movement and the civilian left at home by the members of these factions who returned home following the outbreak of the revolution. The result was the creation in mid-1975 and early 1976 of the 
Ethiopian People's Revolutionary Party (EPRP) and the All-Ethiopian Socialist Movement (MEISON - Amharic acronym).

\section{Collaboration and confrontation}

Both MEISON and EPRP played significant roles in the development of political events in Ethiopia between 1975 and 1978. By and large, the negative influences of these organizations on the Ethiopian revolution outweighed their overall positive contribution. Certainly, the chaos, cleavages and bloody conflicts that characterized the Ethiopian revolution after 1976 and the subsequent military rule emerged partly as the result of the rifts and conflicts that existed between the two groups. The "Red Terror" that claimed the lives of thousands of young students and intellectuals had its roots in the disputes between the EPRP and MEISON.

Although EPRP and MEISON differed on some issues the main cause for antagonism revolved around political power. Each organization considered itself to be the sole leader of the revolution and the basis of the party which would control state power. The organizations chose different roads to achieve their goals. MEISON chose to work with the Dergue in order to replace it at a later stage, while the EPRP directed its energies towards antagonizing the military regime in order to grab the reins of state from its control. The leaders of both organizations made fatal miscalculations and misjudgements. Their underestimation of the military capacity for political manoeuvre and the physical elimination of its opponents resulted in the eventual demise of both MEISON and EPRP as viable political organizations at the centre.

MEISON was dominated by intellectuals who had lived in Europe for a long time. Through its collaboration with the Dergue it sought to gain control of the important institutions and, gradually, the whole of society. In the final analysis, this would enable MEISON to grip state power and send the military back to their barracks. MEISON called its tactical collaboration with the Dergue 'critical support'. But its alliance with the regime was more than critical support since it involved organic links through the Provisional Office for Mass Organizational Affairs (POMOA), also known as the politburo, and the Yekatit' 66 Political School which trained political cadres. MEISON dominated the former and ran the latter. To put it in Lefort's revealing words, "MEISON was officially promoted to the rank of political commissar of the revolution" (1983:167). Through its organic links with the Dergue MEISON participated in the formulation of most of the policies of the Dergue and in the initiation and execution of the "Red Terror" until it became a victim of its own creation in 1978.

The EPRP condemned any cooperation with the Dergue which it characterized as "fascists". It argued that the Dergue had to be fought and removed because the army was a mere instrument of the coalition between imperialism, the feudal bourgeoisie and the bureaucracy and, hence, was against the interests of the masses ${ }^{2}$. The EPRP demanded the immediate installation of a provisional people's government and embarked on urban guerrilla warfare to remove the military from political power.

The responses of the Dergue and MEISON were non-compromising and became more aggressive when the EPRP began to 'eliminate' members and supporters of the two organizations. The Dergue and MEISON declared war on the EPRP which they labelled as an "anti-revolutionary and anarchist organization". The battle cry of the 
Dergue was "for every revolutionary killed a thousand counter-revolutionaries". When the motto was actualized, only a few of the thousand "counter-revolutionaries" who were executed had anything to do with the EPRP but, as the events on the eve of May Day 1977 revealed, most were uninvolved civilian bystanders.

The question of political power and the control of the state is the central issue of every revolution. In a socialist revolution it is the working class, or the proletariat, who struggle to capture control of the state from a higher class, often the bourgeoisie. The absence of a viable working class (there were only around 70,000 registered members of labour unions in the country in 1974) and above all the lack of a political party led to a military take over when the absolutist state crumbled under the fury of the popular upsurge. Then the real battle for the conquest of power began. The battle was not waged across class lines but within the boundaries of one class or, rather, within a strata of a class: the petty bourgeoisie. But since what was at stake was the control of society, and as the society was used as the battle ground, the effects of the conflict were felt beyond the class boundaries of the petty bourgeoisie.

The conflict eliminated a whole generation of educated Ethiopians and affected millions of homes. It took such a bloody turn not because of fundamental differences between the combatants, but primarily because of a traditional Abyssinian dislike of compromise.' The inability to compromise characterised the leadership of the two civilian organizations (MEISON and EPRP), and eventually brought about their mutual destruction.

The conflict within the civilian left was cleverly exploited by the Dergue. Their initial cooperation with the MEISON helped them not only to gain a semblance of radicalness but also to give the EPRP, which was its main adversary in the urban areas, a decisive below. MEISON's turn even came sooner than expected. The conflict between MEISON and the Dergue evolved mainly around the control of the Provisional Office for Mass Organization Affairs (POMOA). MEISON's members occupied the majority of posts in the Central Council of POMOA. It had also gained wide ranging influence in the newly-organized urban mass associations such as the kebeles, trade union, women's and youth organizations by placing its own graduates from the Yekatit '66 Political School in them. The Dergue saw MEISON's influence as a threat to its power. In order to minimize MEISON's influence in the mass organizations and institutions, the Dergue took over the control of the POMOA in a reform proclaimed on July 14, 1977. On August 19 of the same year, MEISON publicized the withdrawal of its 'critical support' to the Dergue which it now accused of betraying the revolution and went underground to wage clandestine struggle (Voice of the Masses, August 19, 1977).

The crack-down upon MEISON had started earlier with the assassination of its members such as Tewodros Bekele, the president of the All-Ethiopian Trade Union (AETU) in January and the murder of Abdullahi Yousuf, the head of POMOA for Hararghe region, and was intensified by the Dergue. MEISON's announcement of its withdrawal from legal political activities to clandestine struggle was ill-timed. Hard-pressed by the Somali invasion of the Ogaden and the continued successes of the Eritrean guerrillas, the Dergue was already in the process of whipping up nationalist sentiment. MEISON's withdrawal was depicted as an integral part of the general counter-revolutionary conspiracy directed against the Ethiopian revolution and the liquadition of members and sympathizers of MEISON was intensified. Once the rift between them was made public the Dergue quickly forced the disappearance 
of MEISON from the political scene. MEISON's inability to continue clandestine struggle showed the unviability of the organization and its lack of a mass base. For example, those who fled to the countryside were caught and brought to the military authorities by the people themselves. ${ }^{4}$

Factionalism and a tendency towards rhetorical simplification of political reality brought about the quick downfall of both the EPRP and MEISON (Halliday and Molyneux, 1981:141). Factionalism between these two civilian groups enabled the Dergue to use one against the other. Their rhetorical orientation affected their dealings with other groups particularly those of the oppressed nationalities. Their flawed analysis of the objective realities in Ethiopia, their over-estimation of their strength $v i s-\grave{a}-v i s$ other groups and of their role in the revolution are among the most important factors that led to their quick disintegration as viable political organizations. ${ }^{5}$

Their stand on the question of nationalities was uncommitted and often contradictory. Both declared in their policy statements the right of nationalities to selfdetermination. But this was nothing more than a make-believe slogan adopted to gain the support of the non-Amhara peoples for in reality they opposed the efforts of the nationalities for self-determination. Genuine organizations of the oppressed peoples were labelled by MEISON as "counter-revolutionary" and their leaders as "narrow nationalists". ${ }^{6}$ Thus the activities of both MEISON and the EPRP led to their own downfall and helped the military to remain itself in power. Above all their opposition to the organizations of the oppressed nationalities created deeper cleavages which proved to be obstacle to united opposition against the military government.

\section{The Question of Nationalities}

In Ethiopia where the conquered peoples constitute the vast majority of the population, the question of nationalities has far-reaching implications. So far the nationalities issue has remained the most intractable problem of the military regime. Until a lasting solution is found multinational Ethiopia seems set to remain an ungovernable centre of political conflict and social and economic crisis. In that respect the analysis of the nationalities question is a very relevant issue in our study because the resolution of this problem is also an important pre-requisite to the solution of the refugee problem in the area.

As we have already indicated, opposition among the non-Amhara nations and nationalities was one of the major factors which led to the outbreak of the Ethiopian revolution in 1974. Even if the overthrow of the ancien régime was not a direct outcome of the tensions between the centre and periphery (the Amhara government and the provinces), the revolts among the Oromo in Bale and the struggle of the Eritrean peoples for independence had played an important role in weakening the imperial state by demoralizing its armed forces and dividing its civilian personnel. These national movements also contributed to the radicalization of the student movement, which evolved in late 1960s and early 1970s as the most important opposition among the urban petty bourgeoisie.

As the question of nationalities had played a central role in the evolution of events which led to the revolution, it deserved priority immediately after the uprising of 
February 1974. The concurrence of class and national oppression in the conquered areas required an immediate solution of the nationalities problem. The Dergue, having proclaimed land reform, maintained that it had tackled class oppression and exploitation. But inequality in Ethiopia's conquered provinces is much deeper than economic exploitation since it involves profound cultural discrimination, linguistic and religious suppression and political domination. The Dergue not only failed to do away with these inequalities but has even acted in a manner which has preserved the old attitudes on the subject of nationalities and exacerbated the hostility of the oppressed peoples towards the centre. And herein lies the source of much of the conflicts that plague the country and which have caused the colossal human tragedy and refugee problems that we witness today in the Horn of Africa. It is a quagmire out of which the military government may not at all manage to pull itself.

From the very beginning, the military regime's policy on the nationalities issue was intransigent, uncompromising and centrist. 'Ethiopia Tikdem', the indivisibility of Ethiopia both in theory and practice, was stressed in every policy proclamation, at every public gathering and in every press release. Some writers have implied that the Dergue's adoption of 'scientific socialism' was to blunt the twin challenge confronting the post-revolution state from alienated classes and dissident nationalist movements. Neverthless, its policy on the issue of nationalities contradicts Marxist theory and practice. Marxism concedes the right of secession and favours unity of nationalities only on a voluntary basis. On the contrary the Dergue considered any call for secession as treason or a counter-revolutionary conspiracy punishable by death. Unlike Lenin and the Bolsheviks who sought the resolution of the nationalities question and denounced the wrongs which the previous system had exercised upon the non-Russian peoples, Mengistu and his colleagues responded to the demands of the oppressed peoples with repression. Those who expressed the aspirations of national equality were alienated, exiled, suppressed, imprisoned or persecuted. The lack of a conciliatory approach by the regime and the absence of a democratic process working towards equality between the dominant and dominated nationalities have inter alia driven the conscious elements of the latter either into the jungles and mountains to wage armed struggle or into exile to organize political opposition from abroad.

The lack of democratic rights has led to the proliferation of national movements and liberation fronts engaged in armed struggle. This has necessitated the maintenance of a garrison army that consumes a large share of national resources. The armed forces have, increased nearly ten-fold since the revolution. In 1977, there were more than 500,000 men in the militia force alone (PMAC, 1977). The escalation of war on many fronts riaturally brought about a large-scale re-allocation of resources for military purposes and a general impoverishment of the country.

First, the meagre foreign exchange reserve was depleted through the purchase of arms and ammunition to meet the challenge from the different national liberation fronts and the Somali invasion. Ethiopia's military budget has increased by several hundred percent in real terms. The value of arms imported between 1976-1980alone amounted to over two billion dollars which, according to Luckman and Bekele $(1984: 16)$, is almost half of the value of arms transferred to the whole of Africa during the preceding five years. Since 1977, more than a third of Ethiopia's GNP has been "gobbled up" by military expenses. Imports of military hardware annually consumes about 10 percent of the country's GNP. In order to raise funds for weapon 
imports and the maintenance of the enormous armed force the Dergue has resorted to new methodes of surplus extraction. Enforced contributions both in cash and kind, forced labour to produce cash crops buying of farm products from peasants at very low prices are some of the ways in which the government raises funds for the maintenance of the armed forces.

The Dergue's inability to find a solution to the nationalities question has had negative consequences for the social and material development of the country. The benefits which would have accrued to the peasants and the national economy after the land reform were obliterated by persistent conflicts. The unconciliatory attitude of the Dergue to the nationalities question has directly or indirectly led to a decrease in rural production because the regime's methods of surplus extraction have killed peasant initiative. The large-scale conscription into the militia has also severely depleted the rural labour force.. Both of these factors have greatly exacerbated refugee flows from Ethiopia during the last ten years.

Notwithstanding the Dergue's socialist rhetoric, the peasantry are today as exploited as they were under the feudal system. Abject poverty is more widespread than ever before and mass starvation more frequent. The land reform has certainly altered social class relations in the rural areas but, as Petras and Morley (1984:21) have poignantly pointed out, "from the perspective of the peasant, life has not improved and landlord induced insecurities are replaced by new state inflicted concerns". The Dergue has preserved the imperial legacy minus its feudal trappings and components. The agents of the central state dominated by the military élite control all the mass organizations, dictating terms and conditions for the allocation of offices, privileges and resources.

National chauvinism vs dissident nationalism

Halliday and Molyneux (1981:42) have remarked that, far from leading to emancipation from oppression or to greater tolerance, some Third World revolutions of the 1970s have instead led to new outbreaks of repression, racism and chauvinism. This is the case with the Ethiopian revolution where the Dergue, contrary to its initial promises to democratize the state, has failed to solve the nationalities issue. Instead, it has reacted punitively to the demands of the opposition in general and the oppressed nationalities in particular. Lionel Cliffe and John Markakis note that "it was easier for a non-Amhara to pass through the eye of a needle than to enter the charmed circle of power and privilege in imperial Ethiopia and it was such barriers which forced the conscious elements of the subordinate groups to choose the perilious course of revolution" (1984:4).

The revolution did not result in proportional power-sharing and opportunities as the social composition of the state apparatus and political power has become even more exclusively Amhara based. This can be verified by just a casual look at the composition of the main political and administrative institutions since the middle of the 1970s. For example, of the 123 central committee members of the Commission for Organizing the Workers' Party of Ethiopia (COPWE), 109 were Amhara (Baxter 1983:131; Halliday and Molyneux, 1981:165). When the Worker's Party of Ethiopia was formally announced on September 12,1984, nine out of the 11 members of its politburo were Amhara. Interestingly, the remaining two were from Tigray and Eritrea. None of the conquered nationalities, including the Oromo, are represented 
in this important decision making organ. The composition remained more or less the same after the declaration of the Socialist Republic of Ethiopia in 1987.

No significant changes were made regarding the share of the Muslim population in the politics of the state. As under the previous regimes they are still excluded from state offices. Although they constitute at least 50 per cent of the population, there was not a single Muslim in the party'spolitburo. This is true even of the country-wide mass associations organized by the Dergue. The Central Committees of the 'Revolutionary Ethiopia Youth Association' (REYA) and the 'Revolutionary Ethiopia Women's Association (REWA) that were elected in September 1980 did not have a single Muslim member (Qay Faana, Vol. 2, no. 9, 1980).

This contradicts the aspirations of the majority of the population. As Rene Lefort (1983:59) has correctly observed, one of the main goals of the Ethiopian revolution from the viewpoint of the subject peoples was to change the Amhara identity of political power and to redress the inequalities inherent in the social structure of the colonial social formation. In the hands of the Dergue the revolution was skilfully converted into an expression of aggressive but covert Amhara nationalism. Covert, because it is expressed in the broader terms of Ethiopia Tikdem (Ethiopia First) and ennat ager weym mot (Motherland or Death). In other words Amhara nationalism is expressed as Ethiopian nationalism because "it is both convenient and self-serving for the Amhara to champion Ethiopian nationalism" (Markakis, 1984:556).

The nationalism which the Dergue represents is the reflection of Amhara nationalism of the bloody period of the formation of the Ethiopian empire. State ceremonies and official speeches, particularly from 1976 to 1979 were nostalgically reminiscent of this period. Besides 'Revolution Square', Menelik's Avenue, with its large mounted statue of the emperor, became the focus of major official ceremonies. The tomb of Tewodros, the father of Abyssinian nationalism, was also visited and venerated by Mengistu in the inaccessible mountains of $\mathrm{Lasta}^{7}$.

The resettlement of hundreds of thousands of peasants from north to south should, inter alia, be related to this atavistic nationalism. As we have discussed at length in previous sections, the settlement of armed garrisons in the peripheries of their kingdom was part of the traditional process of Abyssinian colonization. The massive relocation of armed Amhara and Tigre peasants to rebellious parts of the annexed regions is but an extension of the naftanya military colonies of former times (cf. Triulzi, 1983:123).

The type of nationalism which the Dergue stands for needs a strong central goverment to sustain it. The Dergue, torn by internal dissension and defection is far from that. It also requires an enormous amount of resources to rule a large country like Ethiopia by force. Notwithstanding the massive foreign military assistance and substantial economic aid, the regime lacks both the human and material resources to resolve the political and economic problems of Ethiopia. Therefore, its uncompromising position vis-a-vis the oppressed nationalities is rather unpragmatic.

How can we account for the Dergue's position regarding the interrelated issues of political democracy and the question of nationalities? Halliday and Molyneux (1981: 38-50, 155-159) have suggested that both the Dergue's attitude and the resistance staged by the nationalities are general conjunctural phenomena common to all social revolutions. Their proposition envisages a set of contradictions characteristic of a period of revolutionary transition from one to another and different mode of production. We do not subscribe to what Halliday and Molyneux have posited in this 
respect, because it would be wrong to draw parallels between the concentration of political power in the hands of Amhara Clites and the denial of democratic rights to the subject nationalities, and the centralizing policies of some of the great social revolutions of our time. Halliday and Molyneux have produced a convoluted analysis of the theme but have overlooked the social background of the Dergue as a factor explaining its position on the question of nationalities and its promotion of the unequal distribution of political offices and opportunities among different groups. We see this intransigence as an aspect of national and class interest rather than as a conjunctural and transitional phenomenon.

Sociological theory indicates that a privileged group will not voluntarily renounce its privilege and that social change can only be brought about by the pressure of dispossessed groups. By virtue of their national and class origins, the members of the Dergue were and remain a privileged group. The major employer in Ethiopia is the state, and the granting of autonomy to the subject nationalities would mean a great loss for the Amhara petty bourgeoisie whose main source of livelihood is the state bureaucracy. Of the 14 regions in Ethiopia the Amhara are the majority only in Gojjam and Gonder. If regional autonomy would mean the use of the local language and the employment of local people in public office, it would lead to a major unemployment crisis for the urbanized and educated Amhara. It would mean the loss of economic control and political power for the privileged naftanya or settler group from which the Dergue mainly originates. What the Amhara landlords lost through the nationalization of land is partly compensated for by their control over political power, bureaucratic posts, the nationalized sectors of the economy and state revenues. The granting of democratic rights to the various nationalities would mean a redistribution of opportunities, resources and privileges. Given the national and class backgrounds of the Dergue, a lasting solution to the question of nationalities can hardly be expected.

\section{Dissident nationalism}

Dissident nationalism as represented by the Oromo, Somali and Eritrean liberation movements has its origin in the colonial history of the Ethiopian empire. Nevertheless, the aggressive propagation of Ethiopian (Amhara) nationalism by the Dergue has greatly activated it. The acceptance of Ethiopian nationalism which is presented shrouded in socialist rhetoric to the non-Amhara peoples would, as Markakis (1984:556) correctly remarked, mean acquiescence to the continuing primacy of the Amhara. Dissident nationalism is a negation of Amhara supermacy. It is often labelled as "anti-revolutionary" by the Dergue and by some writers who base their conclusions on rather inadequate information (see for example Chege, 1979) but in reality is libertarian.

The leaders and a good many of the cadres of the major liberation fronts are products of the Ethiopian student movement and the Ethiopian civilian left. Many of them resorted to armed struggle when their dreams of a society free of national domination in a decolonized and democratically restructured Ethiopia failed to materialize. As can be seen from their political programmes and their activities socialism is a central element in the political programmes of the larger nationalist movements such as the Eritrean People's Liberation Front (EPLF), the Oromo Liberation Front (OLF) and the Tigray People's Liberation Front (TPLF). 


\section{Conclusion}

The Ethiopian revolution was primarily the result of long-standing structural crisis and social tensions which were activated by conjunctural factors of both an internal and external nature. Because of its organizational superiority and its possession of the means of coercion, the military was the main actor in the revolutionary transformation that brought down Haile Selassie's regime. Although active in their opposition against the feudal order long before the military saw the need for change, the intelligentsia and the working class lacked the required politicalorganization and could not fill the power vacuum created by the demise of the ancien régime. What is more, rivalry and conflicts severely impaired the capacity of the intellectuals and the civilian left and brought about their premature disappearance from the scene at the centre.

After an initial period of hesitation and toying with the idea of constitutional monarchy, the Dergue announced its choice of socialism as the path of development for the country. The regime made a number of proclamations which were to bring about radical changes. It promised to abolish all forms of inequality in the multinational empire state and to promote rapid and self-reliant socio-economic development. Major and minor industrial enterprises, rural lands and urban housing were nationalized. The question of nationalities was raised and reforms which recognized their rights to self-determination were promised. However, few of the proclamations and promises were realized. In fact contradictions between formal policy and political action have characterized the military rule.

The land reform was perhaps the most radical change that resulted from the revolution. It changed significantly social-class relations in the countryside and brought an end to feudal land-lordism. Nevertheless, it did not improve the standard of life of the rural population. ${ }^{8}$ Following nationalization, the state became the sole owner of land. The peasantry were given plots of land over which they had only usufructuary rights. This created tenurial insecurity and discouraged long-term investment and the improvement of agricultural production'. The regime also introduced a marketing policy which became a major constraint on food production and distribution. The policy forced peasants to sell their produce to the state owned Agricultural Marketing Corporation (AMC) which paid them only half of the price of the open market.

The Dergue's tendency to solve political problems using military means also had deleterious effects on economic production. Hundreds of thousands of peasants in their prime productive ages were drawn into the militia, and few ever returned. On top of the heavily increased taxes, the peasantry were forced to make recurrent material contributions which the regime used to cover its military expenses.

The policy affected industrial production as well. The nationalization of industries reduced private incentive to invest. Skilled workers and managers were imprisoned, killed or exiled during the chaotic period of the "Red Terror". Industrial production was also impaired by Mengistu's slogan of "everything to the war front". Industrial workers were recruited into the militia. Publicinvestment was adversely affected by the diversion of resources and capital to warfare. Unproductive administrative and propaganda activities ${ }^{10}$ were prioritized and expanded enormously at the cost of productive enterprises. 
The overall result of the "militarization" of Ethiopia's economy under the Dergue is the continued deterioration of the standard of living for the vast majority of its inhabitants. Food prices have quadrupled since the revolution while wages and salaries (except for the military) have remained almost stagnant. Consequently famine has become an almost everyday reality not only in those provinces which were visited by cyclical droughts but also in other normally self-sufficient areas. Today millions of people in Ethiopia depend on international food handouts to stay alive. Ethiopia's poor performance under the present regime is not limited to the economic sector but also concern fundamental political and human rights. Few of the democratic rights promised in the numerous proclamations and communiqués were ever implemented. In fact, the regime's political actions have often contradicted the proclamations. Subordination to military rule is expected from all groups in the society. Dissidence is repressed severely whenever and wherever it occurs.

Peasants' and urban-dwellers' associations, workers' unions, and women and youth organizations were formally organized. But popular participation in the political, decision-making process was not promoted. These organizations served rather as channels through which the regime passed down its directives and controlled the masses.

Promises of political and cultural rights to the non-Amhara peoples were contradicted, as the stand of the Dergue on the nationalities question differed little from its feudal predecessors. For the oppressed nationalities the abolition of the inequality was the raison d'etre of the revolution. These hopes and expectations were frustrated by the authoritarian and centralizing policies of the military rulers. Instead of encouraging voluntary integration of the nationalities in the country's socio-political structure, the Dergue demanded unity by force. Power became even more concentrated in the hands of the Amhara ruling minority than under previous regimes. The process of Amharization was intensified, disguised as projects such as "resettlement" and "villagization" (see Chapter 5). Even the much applauded alphabetization programme was part of this process.".

The consequence of this policy was the intensification of conflict between the state and the liberation fronts. The persistence of minority rule has opened a Pandora's box of conflicts and has turned every corner of the country into a theatre of war. The war costs hundreds of millions of dollars every year.

Foreign intervention has always played a decisive role in political conflicts in the history of the area. The Abyssinians, and more recently the Amhara, have always gained the upper hand over their neighbours with the help of foreign intervention. The Portuguese helped Christian Abyssinia to defeat Muslim lowlanders in the 15th century. European colonial powers helped Menelik to conquer the Oromo, the Sidama and Somali and to build an empire. The British and later the Americans assisted Haile Selassie to control the dissident peripheries. Now it is the turn of the Russians. The main problem with super-power involvement in such conflicts is its capacity for undermining the possibilitiesfor compromise between the combatants. Those in power use the imbalance created by the intervention to maintain their position. But super-power assistance may not always result in victory over the other parties. Hence conflict continues. The result is human suffering and uprooting. The uncompromising policy of the Dergue has in various ways spurred involuntary mass-migrations of an unprecedented scale both within and out of Ethiopia. The specific ways in which this policy generates refugee flows are the subject of Chapter 
5. Now we will proceed to Chapter 4 and present the conceptual and methodological framework used in the rest of this study. 


\section{PART II}

\section{THE FLIGHT}





\section{The Conceptual and Methodological Framework}

\section{Introduction}

The purpose of this chapter is two-fold. In the first section we will present a theoretical framework for the analysis of the problem at hand, define the central concepts and clarify some of the sociological terms employed in the ensuing chapters of this book. The second section is devoted to a description of the methods used in the data collection. First, however, we shall comment on the status of refugee research in Africa.

\section{The paucity of theoretical literature}

Refugee problems have, so far, attracted limited interest from social scientists and a general epistemological approach is lacking. Most of the studies conducted on refugee movements are fragmentary and deal primarily with specific problems of settlement and adjustment in host countries. Very little of the available literature focuses on causes or events preceding flight. Moreover, studies that combine the flight and settlement phases or provide a holistic perspective of refugee movements are very rare.

Much of the research conducted hitherto in Africa addresses itself to practical problems concerning the provision of asylum and protection (Aiboni, 1978; Melander and Nobel, 1978; Melander, 1980; Nobel, 1982), the allocation of resources within refugee communities (Christensen, 1982), the status of spontaneously settled refugees (Chambers, 1979,1982,1984) and the economic viability of organized rural land settlements (Kibreab, 1985). In contrast to research in other parts of the world, the literature on African refugees emphasizes collectivities, with the individual rarely the unit of analysis. Therefore, very little information is available on the psychological consequences of flight for African refugees.

Some detailed histories of particular refugee movements and settlements are available. A case history of the Rwandan refugees (Christensen, 1978) and the Qala en Nahal settlement in eastern Sudan (Rogge, 1975) are some examples. International humanitarian organizations and their policies of assistance are also themes of scholarly studies. Shelly Pitterman (1984) has provided a critical analysis of the determinants of UNHCR assistance policy to African refugees. Barbara HarrellBond (1986) has conducted a revealing study of emergency assistance to Ugandan refugees in southern Sudan.

Very little study has been made on the refugee population that is the subject of this book. Only three of the eight sites (Gedaref, Tawawa and Um Gulja) were covered by previous studies. Even those studies were based on observations made by official 
missions and consultants during short visits. With the exception of Gaim Kibreab's (1985) study of organized land settlements for Eritrean refugees, no in-depth research has so far been conducted on Ethiopian refugee communities in the Sudan.

In general most of the studies of African refugees give priority to practical questions; theoretical issues are not the main concern. Social science inquiries into social change and economic development among refugees in Africa are rarely comparative (Pitterman, 1984:6). Very few researchers in this field refer to or make use of methods and experiences documented in other fields of inquiry.

Regarding the lack of interest and paucity of theory in refugee research I.M. Rose has this to say:

This most sociological subject has been largely ignored by those who coined the word anomie and have devoted much attention to exploring, examining and explaining various forms of intergroup and interpersonal tensions. Even those who have studied the character and consequence of forced migration rarely have delved into the social and psychological ramifications of those affected by it (1981:11).

The lack of theory in refugee research is attributed mainly to the perception of the problem as a localized and non-recurrent phenomenon which does not fit neatly into distinct categories (Stein and Tomasi, 1981:6).

Different forces create different refugee movements in different parts of the world. This lends a sense of uniqueness to each situation and clouds our ability to see the recurring elements in each situation (Kunz, 1973:129).

Consequently there is a general lack of sociological theory and even a problem of the conceptual clarification of refugee migration. Stein and Tomasi (1981:6) have pointed out that, notwithstanding the lack of theory, refugee movements are patterned events and there is what could be called a refugee experience which produces what may be termed a refugee behaviour (emphasis added). Hence, these socially patterned events, experiences and behaviours can be generalized and scientifically conceptualized as distinctly consistent and predictable phenomena.

\section{The Conceptual Framework for the Study}

Kunz has attempted to develop a comprehensive conceptual and theoretical framework which could be applied to the study of involuntary migration. Drawing on the works of Kunz $(1973,1981)$ and Eisenstadt (1954) we divide the migratory process into four general stages:

a) events preceding exodus,

b) immediate factors and "motives" generating exodus,

c) the dynamics and social structure of the migratory process,

d) the interaction and integration in the socio-economicstructure and culture of the receiving society.

We shall look briefly at each of the above stages.

Events preceding exodus

Most researchers dealing with involuntary migration are primarily concerned with 
the flight and the situations or problems which consequently arise in the host society. Therefore they tend to overlook the social conflicts that produce refugees. Our approach differs significantly from those of most other studies of involuntary migration because we view the problem in an historical perspective. In our analysis we take into account Zolberg and Suhrke's (1984) proposition that refugee migrations qua sociological phenomena can be understood better in relation to macro-sociological processes in the history of the society of origin. Refugees are products of social conflicts and such conflicts are not random phenomena. They are results of preceding events that are intelligible in terms of the historical development of a given society and its component parts, classes and ethnic groups, and the international processes that intersect with the domestic forces.

Factors generating exodus: voluntary vs involuntary migration

Human migration as a concept denotes all types of changes of residence. These changes range from movements undertaken "willingly and by choice" to movements generated by threatening circumstances. The former category are called migrants while the latter are referred to as refugees.

It is very difficult to make a clear distinction between migrants and refugees. The distance between the "typical migrant" and "typical refugee" forms a continuum. In the middle of the continuum, the causes of voluntary and involuntary migration overlap and the overlapping area contains a borderline category of dislocated populations. These cause problems for international organizations and governments since they do not fit the international legal definition of refugees. Almost every refugee movement contains this element in varying proportions.

Voluntary migration occurs for a variety of reasons which can be summed up as the "availability of opportunities'.' at the place of destination. The "pull" factor is important in the decision-making process. The migrant makes a choice between possible alternatives: to stay in an environment in which he feels relatively dissatisfied, or to move to an environment which he expects to offer him better possibilities for economic and personal advancement. Therefore, whether voluntary or involuntary, migration in the majority of cases is and should be seen a part of the struggle to survive in a world of inequalities and injustices. As Aga Khan, the former UN High Commissioner for Refugees put it, " . . . it is the flight from poverty and oppression towards the magnet of what appears to be more prosperous and hospitable shores" (Aga Khan, 1983). Nevertheless, there are crucial differences between ordinary migrants and those forced into exile.

The refugee, according to the sociological definition, is a person who moves from his country to another against his will. The "push" factor is very strong in his case and he lacks positive motivation to move and settle elsewhere. Hence a refugee is a sociological type whose situation is characterized by the immediacy of life threatening compulsion deliberately exercised by some agent, and his inability to rely on "his" government for even nominal protection (Hansen, 1981). There is little choice but flight in his case. Victims of natural disasters are also a category with little choice, but the compulsion to move is not the result of being ". ... deliberately forced under life threatening conditions, nor are they formally and in principle denied the protection of their government" (Zolberg and Suhrke, 1984:2). The United Nations Convention of 1951 defines a refugee as: 
an individual who owing to a well-founded fear of being persecuted for reasons of race, religion, nationality membership of a particular social group or political opinion, is outside the country of his nationality and is unable, or owing to such fear, unwilling to avail himself of the protection of that country, or, who not having a nationality or being outside the country of his former habitual residence as a result of such event is unable or, owing to such fear, is unwilling to return to it. (UN, 1951)

The sociological and legal (UN) definitions of a refugee have a common denominator in "fear of danger" or "life-threatening circumstances" posed by human agents as the cause of flight. However the legal definition contained in the UN Convention is rather narrow and does not include persons who flee from man-made life-threatening situations such as war or extreme destitution caused by war.

Refugee categories and social dynamics in mass exoduses

Not all social conflict situations generate refugees. In a particular conflict situation it is the interaction of subjective and objective factors i.e. the social psychological structure of the weak parties in the conflict and the available opportunities for escape that determine the outcome. It is often only a fraction of the affected groups that choose to flee and are successful in doing so (Hansen, 1982:190; Boesch, 1982: 56-57; Prins, 1955: 25-32). As Zolberg and Suhrke, (1984:2) rightly observe the weaker party(ies) often remain (s) in the country of origin where they may face death and repression, accept the prevailing social order, organize resistance or become "internally displaced persons". The exact numbers of such displaced persons are difficult to ascertain but they are estimated to run into several million persons in Africa with Ethiopia toping the list (Horn of Africa, Vol.4,1,1981:4). Thus the formal refugee status as recognized by the international legal system involves only a small minority in a multitude of the uprooted and dispossessed.

Involuntary population movements are made up of forced political migrants, oppressed ethnic and religious minorities, and displaced persons. These broad typologies can be further broken down into categories using such distinguishing variables as motives/reason for flight, form of displacement, position in the social structure of the society of origin and the propensity to integrate in the country of asylum. Analytically we recognize five categories of refugees (Fig.1) and as we shall see later all of them are represented in the current exodus from Ethiopia, in varying degrees. Some of these categories overlap in one or several aspects. The list of categories can therefore be reduced or even lengthened depending upon the criteria used in categorization.

a. Revolutionary activists. Firstly, there are those men and women who have the conviction and "purpose" to overthrow an existing regime. They may be steered by a progressive (as is often the case) or conservative social theory and ideology. Typically, they believe that their political convictions are shared by the majority (Kunz, 1981:43). But there are also those political activists who believe that their social ideology is indispensable for mass liberation and, whether supported by the majority or not, choose exile in order to carry out their plans. The Russian political emigrés in Europe before 1917 (Williams, 1972), the African refugees who have constituted the core of the liberation movements since the 1940s and most of the Latin American exile groups are examples of this category. Members of the various Ethiopian liberation movements and leftist opposition groups also belong here. 
Figure 1. Refugee categories: A conceptual model

\begin{tabular}{|c|c|c|c|c|}
\hline & & & & \\
\hline Category & $\begin{array}{l}\text { Cause of } \\
\text { displacement }\end{array}$ & $\begin{array}{l}\text { Form of } \\
\text { displacement }\end{array}$ & $\begin{array}{l}\text { Position in the social } \\
\text { structure of community } \\
\text { of origin }\end{array}$ & $\begin{array}{l}\text { Integration } \\
\text { propensity }\end{array}$ \\
\hline $\begin{array}{l}\text { 1. Revolutionary } \\
\text { activists }\end{array}$ & $\begin{array}{l}\text { Preparation for re- } \\
\text { volution }\end{array}$ & $\begin{array}{l}\text { Individuals, } \\
\text { Small groups }\end{array}$ & $\begin{array}{l}\text { Middle class (intelle- } \\
\text { actuals) }\end{array}$ & Return-oriented \\
\hline $\begin{array}{l}\text { 2. Contenders for } \\
\text { power (power } \\
\text { elites) }\end{array}$ & $\begin{array}{l}\text { Successsful/abortive } \\
\text { coup }\end{array}$ & Small groups & $\begin{array}{l}\text { Middle class, upper } \\
\text { Class, bureaucrats, } \\
\text { politicians, military } \\
\text { officers }\end{array}$ & Return-oriented \\
\hline $\begin{array}{l}\text { 3. Opponents of } \\
\text { change }\end{array}$ & $\begin{array}{l}\text { Inability to cope } \\
\text { with or unwilling to } \\
\text { accept social change } \\
\text { Conservative social } \\
\text { ideology }\end{array}$ & Small groups & $\begin{array}{l}\text { Mainly upper and middle } \\
\text { classes. But also } \\
\text { members of lower } \\
\text { classes }\end{array}$ & $\begin{array}{l}\text { Return-oriented/ } \\
\text { assimilationists }\end{array}$ \\
\hline $\begin{array}{l}\text { 4. Persecuted } \\
\text { minorities }\end{array}$ & $\begin{array}{l}\text { Racial/religious } \\
\text { persecution by } \\
\text { majority }\end{array}$ & $\begin{array}{l}\text { Large groups, } \\
\text { whole popula- } \\
\text { tions }\end{array}$ & $\begin{array}{l}\text { Whole populations, groups } \\
\text { in flight }\end{array}$ & $\begin{array}{l}\text { Integrationists/ } \\
\text { assimilationists }\end{array}$ \\
\hline $\begin{array}{l}\text { 5. Displaced } \\
\text { masses }\end{array}$ & $\begin{array}{l}\text { Ravages of war } \\
\text { Insecurity }\end{array}$ & Mass & $\begin{array}{l}\text { Mainly peasants but } \\
\text { may include workers }\end{array}$ & $\begin{array}{l}\text { ad hoc adjustment, } \\
\text { eager repatria- } \\
\text { tionists }\end{array}$ \\
\hline
\end{tabular}


The decision to leave is usually made not because of the immediacy of danger but because of anticipation of danger. The departure is well planned and often orderly, the country of destination is deliberately chosen and contacts are established before departure. Once in exile most energy and time are spent on preparation for the changes to be brought about at home and very little effort, if any, is made to integrate socio-culturally into the host society.

The flight of this category of forced political migrants occurs in trickles. Individuals and small groups leave first to be joined later by compatriots and family members. In some respects the migration of these political activitists resembles that of ordinary immigrants as they often leave with the knowledge of the authorities in the country of origin and carry the necessary travel documents, unlike most refugees. However, this similarity with voluntary migrants is superficial. They suffer a greater loss of economic and social status than voluntary migrants.

b. Coup makers and targets of coups. The second category of forced political migrants consists of those who flee because of their involvement in coups or revolutions. The coup or revolution may have been abortive or successful turning the coup makers, the revolutionaries or the members of the fallen government into exiles.

c. Opponents of change. Thirdly, there are those persons who leave their homes because they are not prepared to accept political conditions and changes that have occurred due to a revolution or political change. They tend to have a conservative social ideology and are willing to give up the advantages and comforts of familiar ways for what they hope to be a greater freedom. In the country of asylum, they tend to be eager assimilationists but that may not mean easy absorption into the host society.

Irrespective of their political and ideological orientations, the majority are of the refugees in the above three categories are generally relatively rich, educated males who come from the petty bourgeoise and bourgeois classes. The revolutionary activists are often intellectuals who "betray" their class and become leaders of the struggle of the oppressed masses.

d. Oppressed minorities. The fourth category of refugees consists of racial and religious minorities pushed out by hostilities against them from the members of the majority in the country of origin. The current flight of Assyrians and Syrians from different countries in the Middle East and the recent departure of about twenty thousand Falashas or "Black Jews" from Ethiopia after two thousand years residence in the mountains of Gonder fall under this category. Persecution and oppression might have been exercised against such minorities for centuries, as with the last two groups, but flight often takes place at a given point in time. Such a juncture often coincides with a national crisis such as defeat in war or economic depression which is felt deeply in the wider society. It is during times like these that minorities become the scapegoats. The 'endemic' oppression and discrimination against them become 'epidemic' as members of the dominant group search for a vent for their frustration. But above all flight is dependent upon international factors, particularly the availability of asylum elsewhere.

Although discrimination and persecution from the majority group may have the upperhand in a situation like this, there may occasionally be elements of selfalienation, particularly when the motive to leave is religious belief or the desire for a new way of life.

e. The displaced masses. The fifth and last category consists of the majority of 
people in flight, particularly in Africa. These are those unfortunate people whom Rose called "the human flotsam and jetsam which are caught in the cross currents of conflicts which are not of their direct concern" (1981:18). These are people who are uprooted and displaced by the generalized insecurity produced by conflicts although they are not partners in it or may not be its direct targets. Among the displaced persons

. . . we can identify one of the prototypes of forced migration, i.e. individuals who literally are fleeing the firezone. But we can also identify a more ambiguous sub-group consisting of persons who are less passive than others and, in important respects, behave like ordinary migrants. These are the persons who take the advantage of the legal ambiguities of the refugee migrant distinction and the permeability of the border to relocate in order to avail themselves of opportunities for better life conditions abroad (Zolberg \& Suhrke, 1984:56).

The flight of displaced persons in most cases is acute, often in panic and of mass proportions. In this refugee movement the "push" situations are concentrated and overwhelming (Kunz, 1973:141). Refugees in this category are unprepared for their flight and lack information regarding their destination. Consequently their passage from the country of origin to the country of asylum is filled with hazard.

Large concentrations of displaced persons seem to be more common today than before and are principally related to the widespread use of modern technology in warfare. The "scorched earth" strategy which involves indiscriminate air bombardment of areas controlled or infiltrated by insurgent guerrilla fighters is extensively used today by Third World regimes and their superpower allies. Currently Ethiopia and Afghanistan are clear examples.

In Africa, displaced persons originate mainly from peasant and nomadic communities and the lower strata of the conflict impacted society. Coming from such backgrounds the majority are illiterate and often speak only one language or dialect not always intelligible in the country of asylum. Populations that are uprooted by hostility between governments and guerrilla movements tend to become active and politically conscious in exile, often turning into "living" communities which function as rear support to the guerrilla forces. Their radicalization emanates not only from the flight experience but also from the agitational work carried out by political activists within these communities. The Palestinian case is a prototype of this situation. In the Horn of Africa, the Eritreans in the Sudan and the Ogaden refugees in Somalia are typical examples. The rapidly expanding Oromo refugee communities in Somalia and the Sudan show the same trend.

Refugee flows from a certain country can at a given time consist of one or more of the above categories. As we shall discuss in Chapter 5, the refugee streams from Ethiopia are characterized by the diversity of the "motivations" of the groups and individuals that constitute them. For most refugees, exile is a strategic retreat either for staging political activities or just a period to be spent in waiting for the right opportunity to return home. In general, refugees consider their sojourn in asylum to be short, and the problem that caused their flight transient. However, this is often too optimistic because in reality repatriation is generally remote or impossible, as in the case of the Palestinians, the Eritreans and the Rwandese. Exile often becomes a way of life because the refugee remains an unwilling settler in the country of asylum. This often renders the integration of the refugee into the host society very difficult. 


\section{Integration in the Socio-Economic Structures of the Host Society}

\section{Societal integration: concept and theory}

When different ethnical and cultural groups come to live together their relationship passes through a cycle of contact which is usually peaceful and exploratory at first, followed by competition for scarce resources and perhaps conflict as the result of this competition. The outcome of contact, competition and conflict in such a social milieu in the long-run results in one of three possible conditions: assimilation, integration or segregation (cf. Price, 1969:213).

\section{Assimilation vs integration}

There is controversy among sociologists regarding the use of the concepts of assimilation and integration in the analysis of immigrant experiences and relations with their new social environment. Some sociologists prefer integration, some assimilation and some use the concepts interchangeably, often using them to refer to the different dimensions of the process. Assimilation has been defined as

... a process of change during which the immigrant seeks to identify himself in various respects with members of the host group and becomes less distinguishable from them. Both external and subjective assimilation form the components of the process. One without the other is partial assimilation (Johnson cited in Teske \& Nelson, 174:360).

Those who prefer to use integration for the analysis of this social process maintain that integration carries more clearly the notion of adjustment by both immigrant and non-immigrant. They argue (Borrie, 1959:91) that the concept of assimilation has a physiological implication since it suggests the disappearance of the immigrant's separate origin in the process. Hence when used in a social context it is somewhat analogous to the physiological process whereby nutrients are assimilated into the system of a living organism. The concept of immigrant assimilation provokes similar imagery because it posits a situation of immigrant conformity with the host culture, values, and so on, and their "melting" into the host socio-cultural system (Borrie, 1959).

Assimilation often denotes a unidirectional process of change towards homogeneity, as the cultures and the institutions of the non-migrant group are accepted and begin to prevail over those of immigrants. The process implies a high-low ranking dicotomy (cf. Galtung, 1968:31). The dominant culture of the indigenous groups is accepted by the 'low-ranking' migrant groups. But this does not happen in the majority of the cases as in reality there tends to be change on both sides. Because of this unidirectional connotation of change, the use of the concept in the sociological analysis of migrant-non-migrant group relations and interaction has been seriously questioned by William Bernard:

. . . 'assimilation' besides its misleading biological connotation, implies a one-way street in group relations. It suggests that the newcomer is divested of his old culture completely and is virtually remoulded in everything from clothes to ideology. It denies or ignores the many gifts brought by the immigrant to his new home, and the impact of his ideas, his talents, his hopes upon the community that has admitted him (cited in Borrie, 1959:93). 
Such reaction to the notion of assimilation led, in 1956, to the adoption of the term integration by an international conference on immigration convened by UNESCO and held in Havana to denote the merging process in a multi-cultural and multiethnic setting involving migrants and non-migrants (Borrie, 1959:94). The use of this concept is neither free of problems. Integration is a basic concept in the social sciences. But since it is used in different contexts by different disicplines, there are various definitions of the term.

\section{Durkeim's theory of social integration}

The theory of social integration has its roots in the works of the classical sociologists, particularly that of Emile Durkeim. In The Division of Labour in Society, Durkeim distinguished two modes of integration which he named mechanical and organic solidarity. He saw mechanical solidarity as a sui generis which directly links the individual with the society and which "arises from the fact that a number of states of consciousness (conscience) are cominon to all members of society" (Lukes, 1973:149). By common consciousness he meant uniformity of beliefs and practices which are imposed on all members of society and are maintained under threat of repressive measures. He postulated that mechanicalsolidarity is the mode of integration in traditional societies.

Organic solidarity is the mode of cohesion in more advanced and structurally differentiated social systems. It presupposes a division of labour and the interdependence of the different parts of the social system. Like the parts of an organism, the parts of the social whole reciprocate services. The individual is related to the social whole through his participation in one or more of its parts.

The functionalist schools of sociology and social anthropology follow more or less the basic model laid down by Durkeim and conceptualize social integration as "the problem of coordinating and maintaining viable interrelationships among system units" (Turner, 1978:51). Sociologists using the Marxist approach criticize the structuralist-functionalist model of social organization for offering a utopian tranquillity by emphasising a consensual and static vision of society, neglecting the primacy of conflict in social relations. Instead, they suggest a dialectical approach which recognizes the duality of stability and change and of consensus and conflict as the real faces of society (see Dahrendorf, 1958).

The concept and theory of social integration in the study of migration

The concept of integration is widely used among sociologists to denote the process of immigrant adjustment in a new environment and the relations that obtain between immigrant and non-migrant groups at the various levels of social organization. Bernard conceptualized this process as follows:

Integration is achieved when migrants become a working part of their adopted society, take on many of its attitudes and behaviour patterns and participate freely in its activities, but at the same time retain a measure of their original cultural identity and ethnicity (1973:87).

Implicit in Bernard's descriptive definition is that the parties involved must recognise and accommodate differences in culture, beliefs, and so on for integration to function. The emphasis is on participation in the host society. The phrases "becom- 
ing a working part of the adopted society" and "retain . . . original cultural identity and ethnicity" in the definition imply functional integration and organic solidarity as used by Durkeim. In order to function in their new society, immigrants have to take on the important attitudes and behaviour patterns but there is no need for cultural and normative integration as implied by the concept of "invisibility"in the theory of assimilation.

When referring to refugee relationships with and experiences in their host environments, integration denotes more or less the same process as defined by Bernard. Or, as Barbara Harrell-Bond succinctly put it, integration denotes a situation in which host and refugee communities are able to co-exist, sharing the same resources - both economic and social - with no greater mutual conflict than that which exists within the host community (Harrell-Bond, 1986:7).

In our analysis of the experience and situation of the subjects of this study we will adhere generally to the notion of integration implied in Bernard's definition. However, since different aspects of refugee integration in the host society are discussed, a specific definition for each situation or dimension of integration will be given in the appropriate section.

In the African situation it is more proper to speak of the integration of refugees than their assimilation into the host society for several reasons. As we have indicated before, refugees more often believe that their exile will be of a short duration. Being eager to repatriate when and if conditions change in their country of origin, they are keen to preserve their identity and resistant to assimilation into the host society. Complete absorption into the host society to the point of invisibility undoubtedly takes generations. But integration in the host community can be a much shorter process (Bernard, 1976:277). Moreover, with few exceptions, African societies are multiethnic and the recognition of heterogeneity rather than assimilation of one group by another is their modus vivendi. Such accommodation, as it is understood here, implies a mutual 'live and let live' attitude based on tolerance of differences, solidarity and positive interaction. This is not to suggest a harmonious equilibrium or a static balance between the different groups. Conflict is naturally part of the relationship. The opposite type of accommodation which is based upon withdrawal by the minority group into certain occupations, separate areas of residence or an inferior status can also occur. In this case only a limited degree of tolerance and acceptance is shown towards the minority, and they must learn to survive under extreme social stress. The experience of exiles from Third World countries and economic migrants in contemporary West European societies illustrate this point. This situation denotes marginality of the immigrant groups rather than integration. Marginality, or marginalization as it is often called is a phenomenon often mentioned in relation to migration. Hence a brief overview of the concept and theory is in order.

Marginality: the antithesis of integration

The concept of marginality was first used in sociological discourse by Robert Park (1928) in an article entitled 'Human Migration and the Marginal Man'. The concept was applied by Park on the individual psychological level. He postulated that the marginalized individual is one who shares in the cultural life and traditions of two distinct peoples but is unwilling to break with the past and is unaccepted by the new society (1928:892). According to this view marginality is a function of cultural 
contact, conflict within the individual with regard to old and new cultures and lack of acceptance by the members of the new culture.

Stonequist saw the marginal man as a product of migration which "has transplanted individuals and cultures to such an extent that nearly every land and city is something of a melting-pot of nationalities" (1935:2). According to this view the individuals who grow up in such a situation are likely to face problems, conflicts and decisions peculiar to the situation. Stonequist pointed out that some of the members of subordinate or minority groups are able to live their lives within their own cultures and may not be bothered significantly by the dominant culture.

Stonequist suggested that anyone in transition from one group to another will possess something of the marginal man's character. Persons of mixed blood, Jews and second generation Orientals in the United States are some of the prototypes of the marginal man he cited. He argued that the Jew is a classic illustration of the problem because he is the "traditional minority group", the "perennial migrant" who, because of centuries of social conflict combined with tenacious historical memories, has produced a group consciousness which in turn suspects and resists assimilatory tendencies which go beyond a certain point.

Robert Merton (1968:319-320) emphasized the issue of inclusion/exclusion in the analysis of the problem of marginality and defined the marginal man as one "poised on the edge of several groups but fully accepted by none of them". According to Merton's postulation the marginal man is an ineligible aspirant to membership in a certain group but is unaccepted by it. Having gone through the process of "anticipatory socialization" in adopting the norms and values of the outgroup, he loses his membership in his own group which rejects him for his outgroup orientation.

Stonequist, Park and Merton have applied the concept of marginality at the psychological level to analyze the inner contradictions and the external rejection experienced by individuals in a transcultural situation. But the term is also applied in a collective sense in the study of group integration in the wider society. Hence, marginality has been defined quite broadly to denote the conditions of a variety of sometimes overlapping social groups which include the poor, the unemployed and under-employed immigrants, racial and ethnic minorities and members of other subcultures (Perlman, 1976:93). The concept is widely used by social scientists and policy makers in Latin America where the phenomenon of marginality caused by mass immigration from rural areas to urban centres became the key issue in political discourse and research activities during the last decade. Gino Germani, a Latin American sociologist, defines marginality as ". . . attentuated, incomplete, fractious participation in one or more spheres of activities, and exercise of roles in a given society, subsystem or area of activities" (1981:91).

Non-integration and non-participation in the mainstream of the global society obtain because of two main reasons. Principally, the social system lacks the capacity to absorb the newcomers or rejects and segregates them. Secondly, the newcomers may lack the motivation, attitudes and skills needed for participation. In an extreme situation marginality is characterized by lack of participation in the most important sectors of the social system. But generally marginality is a question of degree rather than absolutes. An individual or a group can be marginalized with regard to certain spheres of life and certain institutions, while being quite integrated in other areas (Perlman, 1976:129). This implies that several areas of marginality can be distinguished. The major ones are (1) economic marginality which implies non-participa- 
tion in the productive system, deprivation in consumption of goods and use of services; (2) social marginality or lack of participation in the dominant culture and of real opportunity for social mobility (3) political marginality or lack of participation in the political life of the wider society (Germani, 1981:92; Perlman, 1976:132ff).

The consequences of marginality are recognized at various levels. At the collective level, the marginalized group or minority is characterized by internal disorganization which involves a lack of group solidarity, cooperation, and a low rate of participation in voluntary associations. Marginals lack the possibility to share in the making of decisions concerning both general social problems and their own personal problems. They lack organizations that could link them with the larger society or represent them in its institutions (Perlman, 1976:121). Divorce rate and family breakdown are high among marginals. Mutual distrust and hostility are more prominent than in the wider society. Pessimism and frustration rank high in the marginality syndrome and are supposed to prohibit self-reliance and promote dependency (Perlman, 1976:146).

Marginality among immigrants and/or refugees may not necessarily result in maladjustment of the individual or social disorganization within the group. Migrants communities may be isolated externally but may also have an internal cohesion which prevent the development of these problems.

\section{Assumptions and research findings on refugee psychological adjustment in the new environment}

Observations by psychologists and clinical psychiatrists suggest the detrimental consequences which uprooting can impose upon human behaviour and mental health. These negative consequences are sometimes referred to as the Social Displacement Syndrome (Tyhurst, 1951; Cohon,1981). The basic indicators of this syndrome are portrayed as feelings of insecurity, powerlessness or apathy, suspiciousness, a sense of guilt in relation to behaviour at the time of flight, exaggerated nostalgia, grief or a sense of bereavement illicited by the loss of roots and the emotional support enjoyed prior to flight, and in some cases alcoholism and anomic behaviour (Pfister-Ammende, 1973; Zwingmann,1973; Harrell-Bond,1986).

From the sociological point of view the feelings of guilt, anxiety, insecurity and powerlessness which the refugee experiences could be conceptualized as functions of real, anticipated or recollected outcomes of social relationships. The life of a refugee is a repertoire of material, political and emotional deprivation. In one way or another most of these deprivations are the results of social relations.

To start with, flight is caused by an individual's or group's relative lack of power or inadequacy to ensure protection against "powerful" others. In exile the sense of inadequacy may be exacerbated as the refugee becomes more and more deprived of most of his means and conditions of existence. Power is a function of social position and social position diminishes with dislocation. The underpinnings of what is called normal life are lost when individuals are dislocated and thrown out of their original social environment. Previously learnt language(s) may become dysfunctional and skills acquired in the previous society may prove to be irrelevant in the new surroundings. Social status and identity also diminish when the social uprooting experienced by refugees occurs. 
Power is not only the ability to influence others and their actions but is also control over oneself and one's own actions. Refugees are to a great extent deprived of such power (Hansen, 1982:14). Decisions are made about them and their lives without their involvement or even sometimes without their consultation. The lack of refugee participation in the making of decisions that affect them exacerbates the powerlessness that is caused by uprooting.

The consequences of powerlessness in relation to their conditions and environment and the situations of their family members left behind during flight are reflected in the refugee's feelings of insecurity and anxiety. However, it would be wrong to assume that deprivation has the same consequences for all categories of refugees. Even individuals in the same refugee group may respond differently in identical situations.

\section{Dimensions of the integration process}

It is clear from the above discussion that integration as a concept implies adjustment or change in both the migrant and non-migrant groups. More adjustment is obviously required from the migrant or refugee group than from the indigenous population. As Eisenstadt (1954:15) has pointed out, even if a heterogenous setting would allow the in-migrating group to retain its own distinct socio-cultural characteristics, there must be a certain transformation amongst the immigrants according to the demands of the new socio-economic and cultural environment. The changes may consist of many phases and dimensions (Bernard, 1973; Berton, 1964; Stone, 1973; Goldlust \& Richmond, 1974). In tracing the various phases of the integration process of groups such as the subjects of this study, one may follow a temporal sequence since changes that are made first are in practical areas of immediate necessity in terms of the means of survival: food, shelter and clothing (Bernard, 1973:99). Social-culturalintegration and social-psychological adjustment comes later. However, this should not be construed to mean that in each phase change occurs in only one aspect or dimension of the process. Each phase constitutes some change in most of the dimension but the change could be more significant in one and less in the other dimensions at each stage.

The multi-dimensionality of the integration process in a mass influx situation is illustrated in Figure 2. The process is determined by a complex interaction of variables prevailing prior to flight and situational determinants operative in the host environment on and after arrival. The outcomes of this interplay of pre- and post-flight conditions may be reflected in the interconnected spheres of the integration field, namely, the objective and the subjective spheres of societal integration (Goldlust and Richmond 1974; Richardson, 1967). The objective sphere includes the economic, social and cultural dimensions of integration. The subjective aspect refers to psychological adjustment to the new social and physical environment. The economic dimension concerns the refugee's means of earning a livelihood, relations between present and past occupational status, or occupational mobility due to flight that may indicate the status which he/she occupies in the economic system of the host society. Self-sufficiency is the basic indicator of integration in the economic sense. The social dimension includes, above all, integration into the networks of primary and secondary social relationships with the members of the host society as well as 


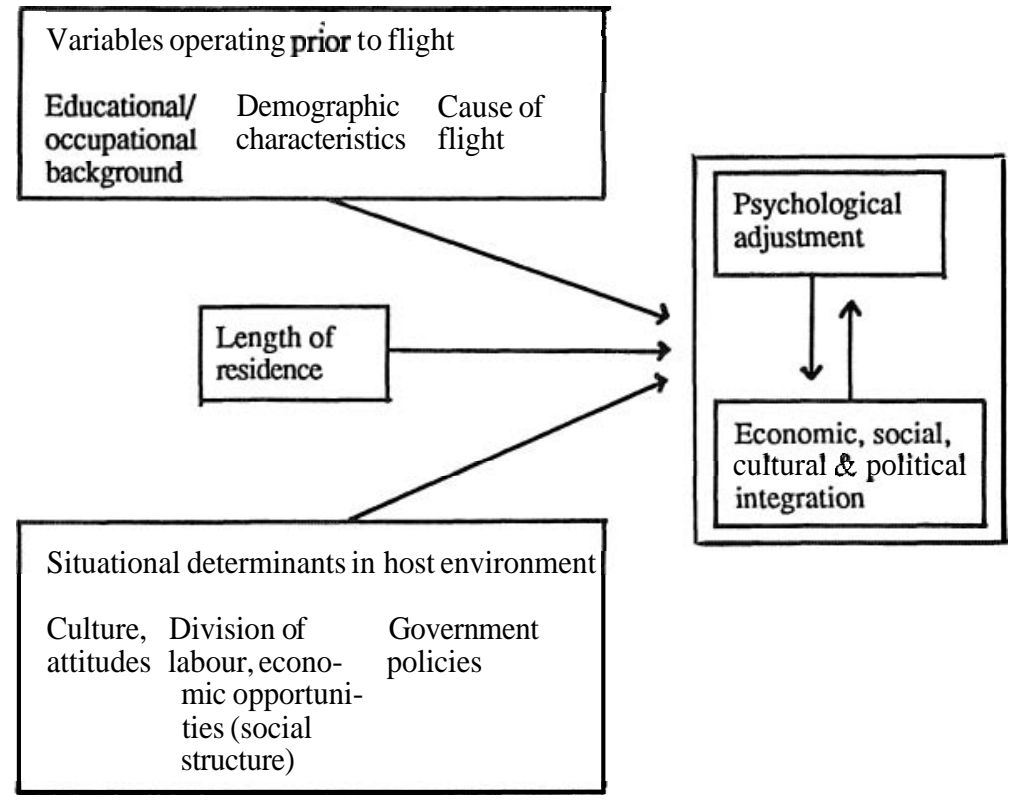

Source: Slightly adapted from Goldlust and Richmond (1974)

within the immigrant community, and the role of social conflict in these relationships. In the cultural sphere the indices of external integration such as language, changes in food habits and changes in clothing styles are very important.

The subjective variables of integration are more psychological than sociological. However, it is assumed that a study of refugee integration would not be complete if it does not take into account their fears and hopes, their attitudes about their new environments and the level of their adjustment or maladjustment with it. Adjustment "refers here to the individual (or group) ability to live and perform various social roles and activities without suffering excessive or unbearable psychological stress" (Germani, 1981:90)

The objective and subjective dimensions of the integration process are influenced by conditions obtaining prior to flight, situations that exist or evolve in the country of asylum, and the length of residence in the host environment. The cause of flight, the demographic characteristics and the educational and occupational backgrounds of refugees are some of the most important variables influencing integration. The conditions in the host environment equally affect the adjustment and absorption of the refugees into the receiving society.

It can be construed with safety that economic opportunities. are pivotal in early adjustment. They facilitate the rate and the scope of integration. Opportunities are determined to a great extent by the division of labour in the host society but also by government policies. The social structure of the receiving society and the attitudes of its members towards immigrants are variables that determine the speed, the direction and level of socio-cultural integration. 


\section{Research methodology}

This study is based on data obtained from primary and secondary sources. The techniques used to gather information are household interviews, participant observation and documentary research. The main body of information was collected through interviews conducted in 413 randomly selected households in eight sample sites. At the time of study there were 23 organized settlements. The spontaneous settlement sites are unkown as refugees from Ethiopia are scattered over the eastern and central regions of the Sudan.

\section{Sources of data}

A questionnaire was prepared using preliminary data collected during the preparatory trip to Sudan in November 1981. It was pre-tested in Tawawa in 1982 and some minor changes were made before embarking on the household survey. The questionnaire (see appendix) was designed to generate data mainly on the demographic profile, the causes of flight, the dynamics of flight, the process of social, cultural and economic integration and psychological adjustment of the respondents and their families in the country of asylum. In addition, several key informants including members of residents' or elders' committees, administrators, health workers, teachers and policemen who have work contacts with refugees were interviewed using another schedule containing open-ended questions.

Secondary data was gathered from various sources. The UNHCR and ILO headquarters in Geneva, the Office of the Commissioner for Refugees (COR) in Khartoum, the UNHCR regional and branch offices in Khartoum and Gedaref and archives of various voluntary organizations were the major sources of such information. Most of the available reports on the refugee problem and other related areas were examined and useful data were obtained. Documents and research reports were exchanged with several researchers who are engaged in the study of the refugee problem in general and that of the Sudan in particular.

One of the central aims of this study is to find out to what extent the current refugee problems can be accounted for in terms of the interaction of past events and present developments. In order to delineate the interconnections of the phenomenon with the past and to get a holistic view of the problem, available historical records, sociological and anthropological reports on the different peoples inhabiting the Horn of Africa were critically studied and analyzed'.

During the field work the author lived among refugees and was able to make a close participatory observation of daily life and conditions in the refugee settlements. The information obtained through participant observation was found to be very useful in supplementing the data obtained from the interviews and the other sources.

\section{Establishing contacts with the research setting}

The field work for this study was conducted in two stages, and two separate field trips to the Sudan were undertaken by the author. The first field trip took place in November 1981 and its purpose was to become familiar with the refugee problem 
Figure 3. Types of settlements, refugees and major sources of subsistence

\begin{tabular}{|c|c|c|c|}
\hline Name of site & Type of settlement & Type of refugees* & $\begin{array}{l}\text { Main source of } \\
\text { subsistence }\end{array}$ \\
\hline Gedaref & $\begin{array}{l}\text { Spontaneous (self- } \\
\text { settling) }\end{array}$ & $\begin{array}{l}\text { Urban } \\
\text { Urban }\end{array}$ & $\begin{array}{l}\text { Wage, petty trade } \\
\text { Wage, petty trade }\end{array}$ \\
\hline Damazin & Spontaneous & Urban & Wage, petty trade \\
\hline Kurmuk & Spontaneous & Urban $^{\mathrm{a}}$ & Wage \\
\hline Tawawa & $\begin{array}{l}\text { Systematic (state } \\
\text { organized) }\end{array}$ & Urban $^{\mathrm{b}}$ & Wage \\
\hline Um Gulja & $\begin{array}{l}\text { Systematic (organiz- } \\
\text { ed) }\end{array}$ & Rural & Wage \\
\hline Um Rakoba & $\begin{array}{l}\text { Systematic (organiz- } \\
\text { ed) }\end{array}$ & Rural & Subsistence farming \\
\hline Yabus & Spontaneous & Rural & Subsistence farming \\
\hline Muguf & Spontaneous & Rural & Subsistence farming \\
\hline
\end{tabular}

${ }^{a}$ Kurmuk is a small town located on the border between Ethiopia and the Sudan (Map 4).

- The semi-urban organized settlement of Tawawa is located on the outskirts of Gedaref which with it circa 130,000 inhabitants is one of the larger towns in the Sudan.

* For analytical purposes respondents from Gedaref, Damazin, Kurmuk and Tawawa are collectively designated as urban refugees. The rest, Um Gulja, Um Rakoba, Yabus and Muguf are called rural refugees.

and the research setting. During this 30-day trip, the necessary contacts with key organizations and institutions dealing with the refugee-problem in the Sudan were made and the aim of the study was explained to them. A preliminary draft of the research design was presented to some key officials in the Office of the Commissioner for Refugees (COR) and the UNHCR office in Khartoum and their comments and suggestions were obtained*. Three sample sites, Gedaref, Tawawa and Damazin were also visited and some basic information collected. This was used primarily to plan the major field work and to prepare the interview schedule. Useful contacts were also established with refugee organizations in Khartoum, Gedaref and Damazin.

The second and major field work phase was conducted from October 1982 to March 1983. Before leaving Sweden for the field, the author obtained the necessary permits from the Sudanese National Research Council (NRC) and the COR in Khartoum to conduct research in the Sudan. On the way to the Sudan the author visited the head offices of the UNHCR and ILO for consultation and very useful letters of introduction to their branch offices in Khartoum were obtained.

In Khartoum the author contacted the COR which issued letters of introduction to its regional offices, the regional security offices and administrators in the two provinces where the study was conducted. Many social scientists have experienced frustrating bureaucratic red tape and myriads of hindrances in conducting research in Third World Countries (see, for example Pausewang, 1973: 34-35). Researchers on refugee problems and issues are no exception ${ }^{2}$. However, the author received prompt support and cooperation from all sections concerned and from individuals in

* Ahmed Karadawi, Assistant Commissioner for Refugees in the COR and Lars Jonsson, Programme Officer in the UNHCR branch office in Gedaref read the research plan and discussed it with the author. The discussions were very valuable. Both of them have written on refugee problems in the Sudan. 


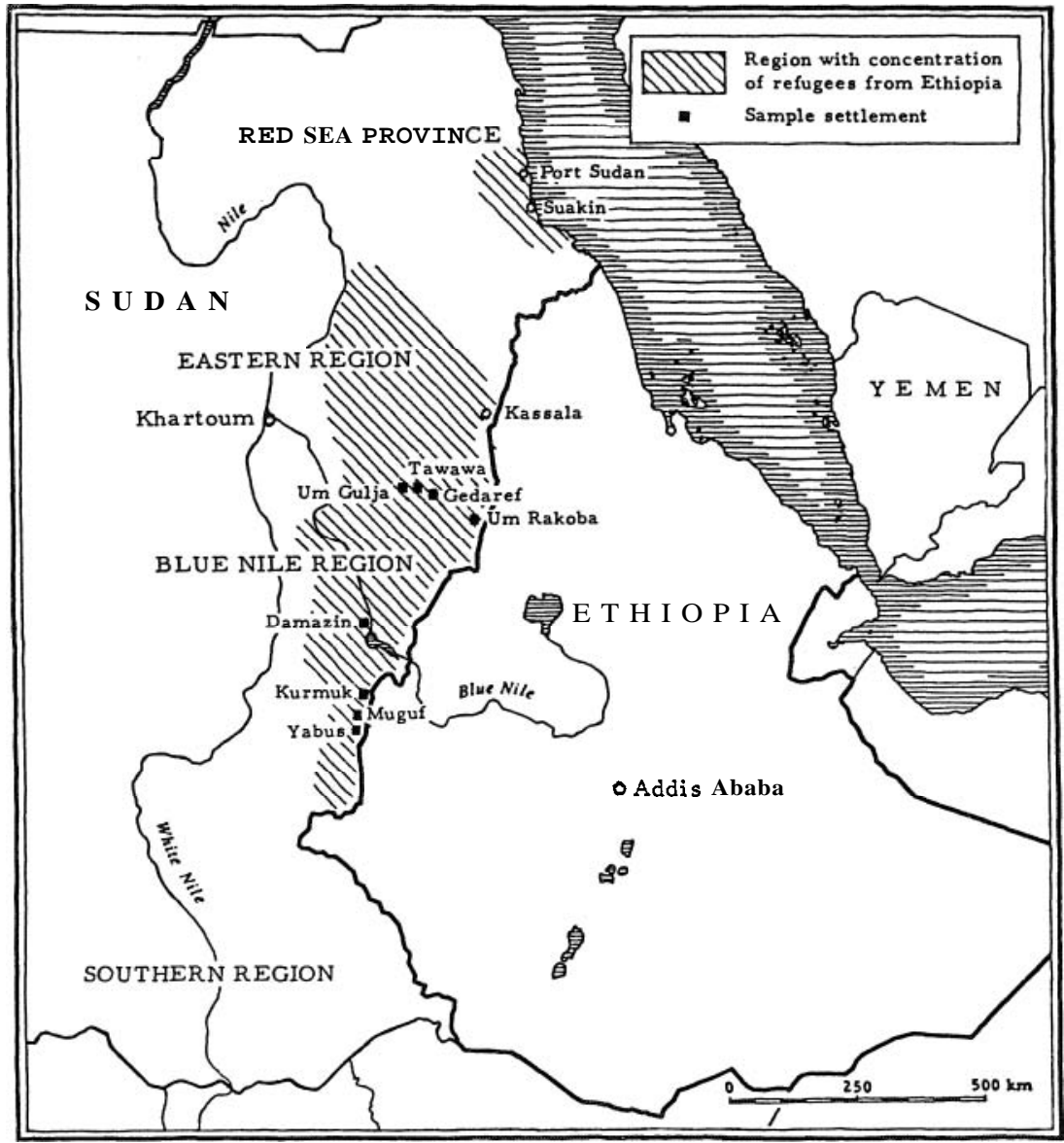

the Sudanese bureaucracy. In the remote border areas particularly in Kurmuk, Muguf and Yabus assistance from the security forces was very crucial and was readily obtained.

\section{Site selection}

The refugee population in Eastern Sudan is diversified in its socioeconomic, cultural and ethnic composition and pattern of settlement. The majority of the refugees originate from rural areas in Ethiopia. However, according to some estimates nearly half of them were, at the time of the survey, accommodated in urban or semi-urban environments (Weaver and Kontos, 1983). Approximately 100,000 lived in organized or systematic settlements run by the Sudanese state in cooperation with the UNHCR and a number of voluntary agencies (NGOs). The rest, which means more than three-fourths were settled in scattered and spontaneous patterns in the major urban centres, in small towns and in rural communities in the border areas. 


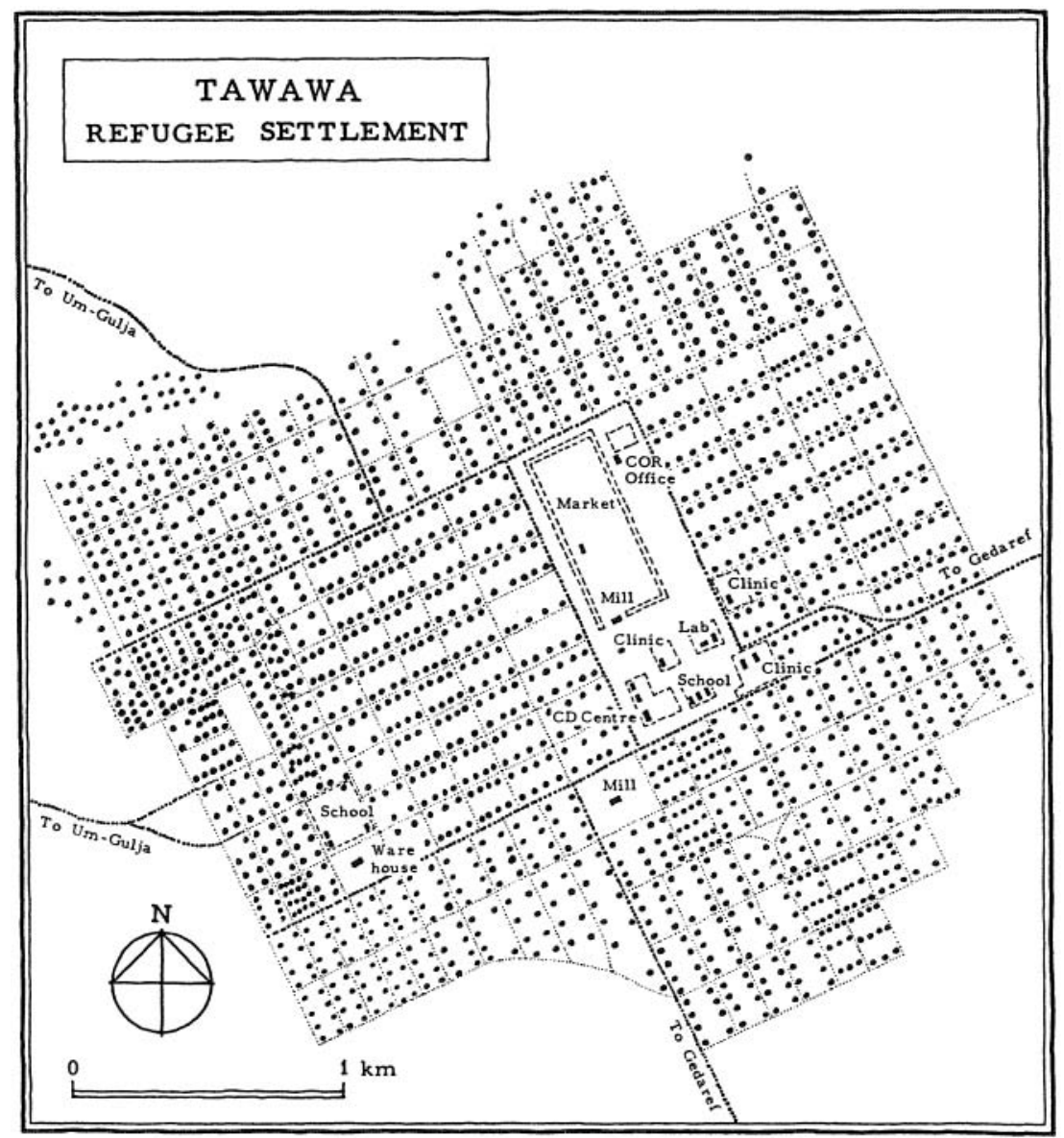

Source: International Rescue Committee.

In this study, eight sites (Figure 3) covering all types and patterns of settlements were selected ${ }^{3}$ and intensively studied. Three of the settlement sites were organized and the rest spontaneous. Three of the sample sites were located in urban settings, one semi-urban and the remaining four were rural environments.

The purpose of including the various categories of settlements in the sample was primarily to obtain a population displaying a wide variety of the characteristics in the research universe. The interview sites were selected purposely after a thorough review of all known sites with significant refugee concentrations.

\section{Drawing the household samples}

Charts (maps) and lists were used to sample out household units and individuals included in this study. Fairly detailed and updated maps with numbered settlement blocks and dwelling units (Map 5) were available in the three organized settlements 
of Tawawa, Um Gulja and Um Rakoba. The maps were prepared by the International Rescue Committee (IRC) and the Sudanese Council of Churches (SCC) to facilitate their service in the settlements.

Lists kept by the police and immigration authorities were available in Damazin and Kurmuk while in Yabus and Muguf household registers compiled by the Oromo Relief Association (ORA) for relief-aid distribution were used to draw the interview samples.

The situation in Gedaref was quite different. Firstly, Gedaref is a rather large city with a population of about 130,000 of which about a quarter were believed to be refugee ${ }^{4}$. Secondly, no lists or addresses of the refugees living there were available. As it was very difficult and time consuming to locate all the refugee households in the city, we were obliged to limit the survey to one area. We selected Deim el Nur, which is one of the deims (sections) with a large refugee concentration, and located those compounds which contained refugee households. The households were identified and listed ${ }^{5}$. A sample of 70 households were then randomly drawn for interview. The samples constituted between 7 and 10 per cent of the households in the organized settlements and between 12 and 16 per cent in the spontaneous urban and rural settings.

\section{Interview procedure}

On arrival in an interview site the author presented to the settlement administrator or other concerned officials letters of introduction and research permission acquired from the higher authorities in Khartoum, Gedaref or Damazin. The official in question was briefed on the purpose of the study and was then requested to call the members of the elders' or residents' committee to a meeting. At these meetings the committee members were informed of the household interviews to be conducted in their community and the purpose explained to them. They were then requested to pass on this information to the residents of the settlement and to persuade them to cooperate with the interviewers.

Each interviewer was then given a list of households in a specific block of a settlement, with a sketch indicating their location. More than 90 per cent of the interviews were thus made in the homes of the residents. In the spontaneous settlements, particularly in Kurmuk and Damazin, this was not always possible and a refugee organization or the immigration authorities were requested to call those selected for interview to a particular place in the community.

Interviews were made with male heads of household and, in their absence, with their wives. This was particularly the case in Tawawa and Um Gulja where the survey was conducted during peak harvest season and nearly 20 per cent of the male household heads were not available for interview. In those cases where the household constituted a group of young men who shared a dwelling unit whoever was at home was interviewed. When more than one member of such a household was present, the person who lived there longest was interviewed. The same principle was applied in those cases where more than one family occupied a dwelling unit.

Each interview took an average of two hours. The interviewers were well received and the data collection went even more smoothly than we had hoped. Very few respondents showed signs of suspiciousness or were reluctant to answer any of the questions. No hostility was encountered in the sites and only five refusals (1.2 per 
cent) were recorded. In general, the interviewers were received with enthusiasm and hospitality, and most of the respondents were eager to tell even more about their experiences than the questions required. Whenever a refusal was encountered the interviewer took the next dwelling unit as a substitute. The same procedure was followed whenever an interviewer failed to find a family at home after three trials. All in all substitutions were made in this manner for about 5 per cent of the households that were originally selected out for interview.

\section{Interviewers}

It was clear from the start that the author could not conduct all the household interviews without some assistance. Therefore, six interviewers were employed, some of them for several weeks, through the regional office of the UNHCR in Gedaref. The interviewers had ideal backgrounds and experience for the job. All of them were refugees and at the time of survey lived among their fellow countrymen in the study area. All of them had been at one time or another employed by humanitarian organizations as teachers or administrative assistants in the refugee settlements. In addition four of them had participated as enumerators in socio-economic surveys conducted by the ILO and the UNHCR in the various refugee settlements in 1982 and the IRC in Tawawa in 1981. As a group, the interviewers and the author spoke five languages (all of the major ones) from Ethiopia, which made it possible to conduct each interview in the language of the respondent. In short, the interviewers were "insiders" who were well informed and aware of the realities of the refugee settlements ${ }^{6}$. The fact that the interviewers were refugees themselves and that many of the respondents knew them personally generally created a cordial interview atmosphere.

The interviewers also had satisfactory academic qualifications. All of them had attended university or college study programmes in Addis Ababa. Three of them had basic degrees, one of them in statistics.

\section{Interviewer training}

Since the interviewers were familiar with interviewing and the research setting, a short, intensive introduction which took two days was found to be sufficient to train them to conduct the interviews. The first day was devoted to a thorough study of the interview schedule. Possible problems which could arise regarding the survey in general and the interview schedule and interview procedure in particular were raised and discussed. The second day was spent on an interview exercise using the schedule. Each interviewer administered a questionnaire in the presence of the author and the other surveyors or enumerators who made note of whatever they regarded as deserving comment in each interview. This exercise was followed by a discussion in the evening using the notes that each interviewer and the author kept during the day. As further training the author accompanied each interviewer for a day during the first week and provided further guidance when needed. Throughout the survey, the author went through all the questionnaires in the evenings with each interviewer and any inconsistencies were corrected without delay. In two cases the interviewers went back to the households next morning to make corrections of inconsistent responses regarding employment and source of income. 
Validity of data and sources of error

There are social scientists who are sceptical about the reliability of data gathered in survey research in Africa. Some of them doubt the validity of applying research methods and concepts that are developed in western academic traditions in African environments. Pausewang (1973: 54-72), for example, mentions the problem of drawing reliable samples and suspiciousness, consciously-provided wrong information, lack of comprehension etc. as major obstacles in the use of survey questionnaires in an African setting.

The doubts of Pausewang and others may be right in some places and under some circumstances but it would be wrong to assume that the survey method is inapplicable in African environments. In fact the problem lies not in the method per se but in its application. The social survey is a perfect tool to elicit information provided the questions asked are proper and concrete, and provided the interviewer is an "insider" or someone who is conversant with the cultural values of the subjects and if questions about opinions concerning abstract ideological issues which might produce unreliable answers due to lack of comprehension by the subject are avoided. Hence, we asked simple and clear questions in the respondent's own language, mainly about events and facts that could be given specific answers. Interviewers who were known to most of the respondents and who shared not only their culture but also knew their conditions were employed.

Obviously there may still be sources of error to which a researcher must be alert. One of the possible sources of error that we anticipated while designing the survey was the question on income. Since refugees expect assistance from outside their communities, there is often a tendency to underestimate incomes and exaggerate material deprivation. In order to minimize this problem we told first the elders' committees and then the respondents that the study had no connection whatsoever with aid and international organizations or government agencies. We assured them that they could expect nothing from the study and that we had come only to record facts for academic purposes. Income figures obtained in this study may therefore approximate to the 'true' incomes of the refugee households better than figures obtained in other surveys. The average income we recorded is almost double and even three times those recorded by others, particularly those sponsored by international organizations (e.g. ILO, UNHCR) and the Sudanese authorities. However, there may still be other sources of error concerning income. For example, the substitution of heads of household and earners of family income by their wives, who might have exaggerated or underestimated income, could be one source of error.

Another possible source of error concerns the age of respondents. As most of the respondents who originated from rural areas were non-literate it was not possible for many of them to give their exact ages. Therefore, we used intervals of 10 years when recording age. The timing of data collection could be the cause for another source of error. We conducted the survey during peak harvest time when most of the refugees are employed and conditions are better. This could distort perceptions and bias conclusions about the life of respondents in their new environment since, as Robert Chambers (1979:383) has indicated, poor people in rural Africa in general and self-settling refugees in particular are vulnerable to seasonal deprivation especially during the rains and before harvest when food is short and morbidity is high. However, we have tried to get income and employment data for the whole year in order to get a balanced picture of the respondents' general economic conditions irrespective of the season. 


\section{Chapter 5}

\section{Immediate Subjective and Objective Causes of Mass Flight from Ethiopia}

\section{Introduction}

Up to 1974, the year of the Ethiopian Revolution, there were less than 50,000 Ethiopian exiles abroad. When the revolution broke out, and particularly after Haile Selassie I was overthrown in September, 1974, many Ethiopians began to return home in anticipation of change and a better politicalclimate. At the same time some members of the ancien régime left the country in opposition to the revolution or to escape arrest for corruption or misrule. Their number was, however, very small.

Table 5.1 clearly demonstrates that the influx was relatively low during the first two years after the revolution. The initial non-violent nature of the change lasted for about two years. Political conflict began to increase in 1976, so that every part of the country and every section of the society was affected. As can be seen in the table nearly 56 per cent of the households covered in this study crossed into the Sudan during this period. The period was characterized, in Ethiopia, by the escalation of war, confusion and the official proclamation of the 'Red Terror' which sent thousands of people into exile. Approximately one-third of the respondents arrived in the Sudan between 1970 and 1982. As we shall discuss in later sections, this period coincides with the institution of forced labour, non-voluntary relocation and resettlement programmes and the deterioration of economic conditions.

Table 5.1 Percentage distribution of respondents by date of arrival in the Sudan

\begin{tabular}{lccccccr}
\hline Year & Gedaref & $\begin{array}{l}\text { Damazin/ } \\
\text { Kurmuk }\end{array}$ & Tawawa & $\begin{array}{c}\text { Um } \\
\text { Gulja }\end{array}$ & $\begin{array}{l}\text { Um } \\
\text { Rakoba }\end{array}$ & $\begin{array}{c}\text { Yabus } \\
\text { Muguf }\end{array}$ & Total \\
\hline & 7.2 & 0.0 & 8.0 & 1.0 & 2.9 & 0.0 & 4.1 \\
1974 & 0.0 & 0.0 & 0.8 & 1.0 & 4.3 & 0.0 & 1.2 \\
1975 & 7.2 & 3.1 & 5.3 & 4.1 & 8.6 & 0.0 & 5.3 \\
1976 & 14.5 & 0.0 & 23.9 & 36.1 & 31.4 & 6.3 & 23.2 \\
1977 & 15.9 & 3.1 & 21.2 & 37.1 & 28.6 & 0.0 & 22.3 \\
& & & & & & & \\
1978 & 5.8 & 0.0 & 8.0 & 6.2 & 4.3 & 62.5 & 10.2 \\
1979 & 5.8 & 0.0 & 3.5 & 3.1 & 5.7 & 3.1 & 3.9 \\
1980 & 5.8 & 3.1 & 12.4 & 3.1 & 4.3 & 25.0 & 8.0 \\
1981 & 26.1 & 28.1 & 5.3 & 1.0 & 5.7 & 0.0 & 9.2 \\
1982 & 11.6 & 62.5 & 11.5 & 7.2 & 4.3 & 3.1 & 12.6 \\
\hline Total \% & 99.9 & 99.9 & 99.9 & 99.9 & 100.0 & 100.0 & 100.0 \\
$\mathrm{~N}$ & 69 & 32 & 113 & 97 & 70 & 32 & 413 \\
\hline
\end{tabular}




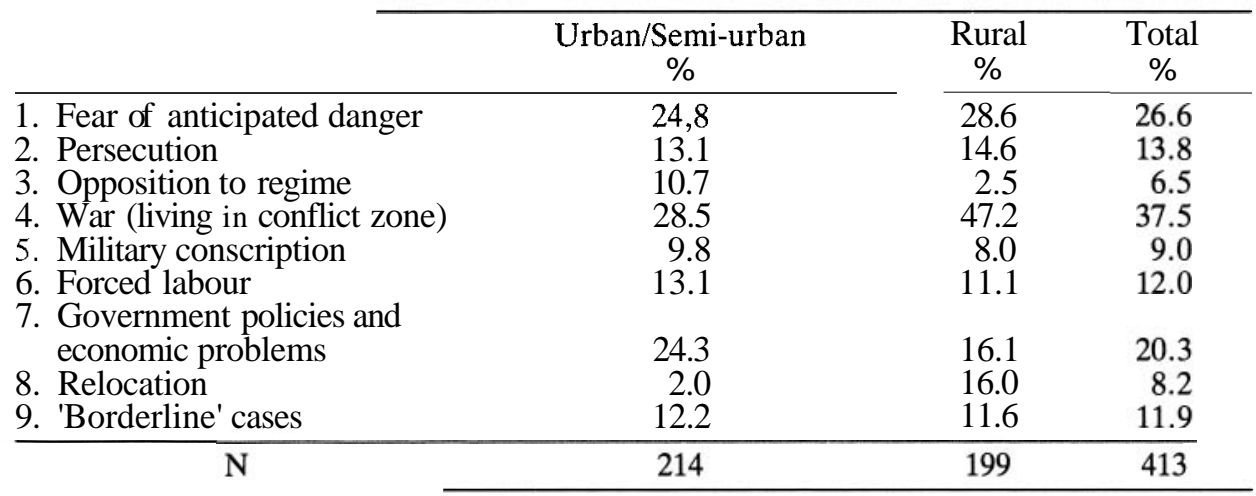

$\mathbf{X}^{2}=0.79,1$ d.f., not significant;Persecution $\mathbf{X}^{2}=0.32$ not significant; Opposition $\mathbf{X}^{2}=12.87$, 1 d.f., $p<.001 ;$ War $\mathbf{X}^{2}=14.92$, 1 d.f., $p<.001$; Military conscription $\mathbf{X}^{2}=0.47$ not significant; Forced labour $\mathbf{X}^{2}=0.36$ not significant;Relocation and economic problems $\mathbf{X}^{2}=4.23,1$ d.f., $\mathrm{p}<.05$; Borderline cases $\mathrm{X}^{2}=0.08$ not significant.

The subjective definitions of causes of flight

In a socio-political environment such as described in the foregoing chapter, the immediate events and circumstances which influence the decision to flee tend to be very complex. Consequently, our focus in this chapter is upon the particular reasons given by those interviewed. Each person was asked to give up to three reasons why he/she left Ethiopia. The responses are summarized in Table 5.2. The respondents are divided into urban and rural categories in order to see whether there were significant variations in the pattern of refugee generating factors in the two settings.

As shown in the table, 26.6 per cent of the respondents gave fear of anticipated danger as one of the main reasons behind their flight. Here fear is a generalized concept for "fear of political persecution" mentioned by 20 per cent of the sample, "fear of religious persecution" by 3 per cent and "fear of war" by a further 3 per cent. Persecution, mainly political but also religious regarding refugees originating from the protestant communities in Wollega, was mentioned by about 14 per cent. Fear and persecution seem to have affected peasants and urban dwellers equally and there is no significant difference between the responses of the two categories on the two variables. Political opposition to the regime as a motive for leaving was mentioned by the smallest group of respondents, only 6.5 per cent. The majority of these were educated young men from urban areas. War (actual) is the major cause of flight and was mentioned by the largest group, 37.5 per cent. Ethiopian military forces are engaged in a war with guerrillas in almost every corner of the country and, as can be seen in the table, the peasantry were more affected by this than the urban population. Conscription to the armed forces particularly the militia, generates refugees because young men leave the country in order to avoid military service. Nine per cent of the respondents crossed the borders for these reasons.

Forced labour or the provision of "free" labour on the state farms was mentioned by 12 per cent and more than 20 per cent of the refugees gave economic problems caused, inter alia, by destruction of property by war, prohibitive taxation and 
confiscation of property by the government, famine and natural disaster and relocation (resettlement of people from the north in southern Ethiopia) as the major reasons for their flight. About 12 per cent of the respondent are "borderline" cases. The main reasons they gave ("seeking job", "education", "medication", "joining relatives", "personal reasons", etc.) for leaving their country resemble motives of voluntary migration. They are a category which do not fit into the legal or even the sociological concept of refugee. However, as they come from conflict-affected environments where education, employment and medical services had been disrupted and where families had disintegrated, it would not be right to categorize them as voluntary migrants. They are borderline cases located in the middle of a continuum linking the typical refugee and the typical migrant.

What we can conclude at this stage from the subjective reasons given by respondents is that political and economic problems are the main refugee producing factors in Ethiopia. But it may not suffice to draw conclusions regarding the genesis of the refugee problem on the basis of subjective definitions since it is difficult to determine whether the reasons given are reliable or not. The respondents had, on the average, been in exile for five years at the time of interview and might have forgotten the particular circumstances which were decisive in their flight. There is also the possibility of "cause" exaggeration in order to obtain the sympathy of the listener. Or, some of the circumstances that influenced the decision to move may have been such that the respondent was not willing to share them with strangers whose motives he or she may have considered suspicious. It is our aim to lay bare the anatomy of refugeeproducing problems in Ethiopia and to obtain a deeper insight into the circumstances that give rise to refugee flows from Ethiopia. This necessitates a broad discussion of some of the subjective reasons given in relation to the objective social, political and economic conditions prevailing in Ethiopia at the time of flight.

\section{Subjective Definitions of Reasons for Flight and Prevalent Objective Conditions}

\section{Violence}

About 27 per cent of the respondents gave anticipated danger posed by human agents as the main reason behind their flight from their homeland and families. Two factors - persecution and armed conflict - were given as the reasons for insecurity. Fear was caused by the experiences of other subjects which the respondents had witnessed or heard rumours about. In some places, particularly where nationalist guerrillas are operating and the peasantry are held collectively responsible for their activities, rumours of an approaching military force often cause panic and lead to the displacement of whole communities. At times arbitrary arrest and torture cause terror which often drive sections of the population into active opposition or flight. Jean-Marie Domenach has defined violence as

... a use of force whether overt or covert, in order to wrest from individuals or groups something that they do not want to give of their own free will. (1981:30)

Thus. violence denotes the relation of forces or actors whose interests are in conflict. 
Sociologists and philosophers belonging to various schools have suggested that violence is inherent in all government systems. Marxist literature posits that the existence of a state necessarily creates conflict of interest between rulers and the ruled, and that such conflict involves violence and counter-violence.

Even if coercion and exploitation are the normal rather than the exceptional relations of rulers to the masses, the degree of force used to acquire consent varies from state to state and from time to time. Paradoxically, violence is a prerequisite of the humanization of social relations. Its nature is dialectical and, hence, violence is used not only in the subjugation of peoples but also in their emancipation. When leaders or regimes represent the vested interests of a minority at the expense of the majority or where leadership and minority groups use power to coercively limit political participation by the masses, violent conflict is not only inevitable but even viewed as reasonable.

The Ethiopian revolution started as a peaceful event and remained relatively bloodless during the first two and half years. Even the land reform which brought about profound changes in the relations of production, particularly in the southern provinces, did not call forth violence of significance and little blood, if any, was spilled when the gabbars ousted their former oppressors and exploiters - the landlords. The confiscation of extra houses in the urban areas and the nationalization of major firms, banks, insurance and transport companies was also accomplished without bloodshed. Hence, extreme violence and counter-violence were not essentially elements of the revolutionary process but were results of contests over the spoils of the revolution. The spoils were political power and previleges. The contestants were the military council, the civilian petty bourgeoisie with the civilian left in the forefront and the national movements whose leaders also belonged to the civilian left. Each party justified the use of violence as its "revolutionary" duty. The Dergue called its use of organized terror as "revolutionary justice"; the EPRP regarded the physical liquidation of individuals as an inevitable means of redeeming the revolution betrayed by "military fascists" and their collaborators. The liberation fronts considered guerrilla activities necessary to cast off the yoke of national subjugation and oppression. Whatever the justification, the consequences of the resultant violence for the wider society were profound. Insecurity, persecution, poverty and social uprooting have become more widespread in Ethiopia than ever before.

\section{Violence and counter-violence}

Nearly 14 per cent of the households covered by our study gave persecution as a major reason for their flight from Ethiopia. Political persecution began to mount in 1976 and reached its peak in $1977-78$ as the result of the proclamation of the so-called Red Terror.

\footnotetext{
'Revolutionary motherland or death' was the choice offered to Ethiopians in 1977 by their new military leaders. For thousands, the choice was all too real. The ruling Provisonal Military Administrative Council (PMAC), the Dergue, made death the penalty for opposition to its rule, although official communiques called it 'revolutionary justice'. Their Marxist opponents were called the 'white terror' against which the Dergue ruthlessly and proudly turned the 'red terror' (Legum and Lee, 1979:17).
}

The "Red Terror" was the Dergue's response to the assassination of its cadres by the EPRP and was therefore mainly directed against its cadres and supporters in the 
urban areas. However, as the persecution was generally carried out by an undisciplined militia, it affected also the innocent urban population. Several factors interacted to make the "Red Terror" a real nightmare for the majority of the urban population. The central committee of the Dergue lacked revolutionary discipline and experience in civil administration. The intellectuals who cooperated with the military were no better. Besides, they were bent on using the situation to eliminate rival intellectuals in opposition groups. At the climax of the "Red Terror" "every morning dozens of corpses of people murdered during the night were ostenstatiously exposed in the streets".' Thus measures taken against the members of the opposition, labelled "anarchists" by the regime, were used to intimidate the population. Their bullet-riddled and mutilated bodies were desecrated and left lying in the streets for days with placards saying "Anarchists", "Enemy of the People" or just "Red Terror".

The victims of the "Red Terror" were denied customary burial and relatives were forbidden to take the body or display signs of grief on pain of arrest and possible execution (Habte Selassie, 1982:42). The bodies of the victims were either dumped into mass graves or thrown into eucalyptus groves. One of the most sacred rituals in most cultures is the burial of the deceased. In Ethiopia the burial ceremony is an occasion that calls not only for the presence of relatives, but the whole neighbourhood. The ceremonies, the food and coffee which are brought to the bereaved household and consumed communally for several days and in some places for several weeks are age-old strategies for coping with grief. The prohibition of burial and mourning for the victims of the "Red Terror", who were often innocent, was seen as a violation of values which concern the very essence of humanity and was cause not only for resentment but also fear ${ }^{2}$. The families of the victims of the "Red Terror" were affected not only socially and psychologically but also economically as their property was automatically confiscated when they were arrested or persecuted. When this involved family bread-winners the sources of livelihood were often closed off completely ${ }^{3}$.

\section{Distorted views of class struggle and personal vendettas}

What made the "Red Terror" a most terrifying episode was the fact that it made individual vendetta possible. The newly-elected kebele (urban dwellers' association) guards, the militia and others used their positions to revenge old grudges! The rather distorted presentation of the concept of class struggle by the state-controlled mass media and by politically untrained cadres misled unemployed shanty-town dwellers particularly in Addis Ababa, into declaring war on the educated and well-off.

The revolution opened the door to this swarm of have-nots, not so much by a share-out of bread and work . . . but rather by giving them the opportunity to become here and now, actors in a battle against the coalition of the well-off ( . . .). It was the moment of revenge for the wretched of the town, those 'outside classes', against all classes mixed up together, the inevitable culmination of the intensification of the class struggle willed by the Dergue, in a city where $40 \%$ of the population had no clearly defined job and the number of inhabitants doubled in six years (Lefort, 1983:200).

The members of the kebele defence guards were mainly recruited from the unemployed and marginalized, and most could not read or write. They were given no political training. Unlimited freedom to arrest or execute anybody they suspected of 
being "anti-revolutionary" was the prerogative conferred upon them in their kebeles. The total immunity they enjoyed and the enormity of power given to-them by the circumstances seem to have intoxicated many of the defence guards. They were unrestricted in the use of their power. Rene Lefort (ibid) claims that they used their weapons freely, not motivated by any political philosophy but "by an insatiable thirst for revenge" and the "gratification of their vanity". Few were paid salaries. Chege asserts that they "survived by extracting surpluses in cash and kind at gunpoint". He adds, "...corrupt, undisciplined and undisciplinable, the urban kebeles came to be dreaded by the population for their unrestrained terror" (1979:373). The observations of these authors reflect more or less the experience of the urban population during the chaotic period of the "Red Terror".

The Dergue not only used class contradictions to carry out the terror but also exploited the contradictions between town and country to settle accounts with its opponents. This resulted in a major loss for the urban population particularly for families with teenage children.

The worst came with the arrival of defence squads from the countryside . . They chased the demonstrators in four directions and then closing in, opened fire on them with machine guns. They had been given lists of secondary schools and student 'opponents' drawn upon the basis of the most elementary criterion-irregular attendance at classes. House by house, the militia hunted down the 'suspects' and executed them summarily (Lefort, 1983:200).

In one incident alone (of April 29, 1977) more than 500 school children were massacred in Addis Ababa (Halliday \& Molyneux, 1981:122). The presence of hundreds of armed kebele guards and rural militia in the city, and the uncoordinated searches of homes and individuals magnified the terror. The chaos was further exacerbated by the revocation of the legal system and the total collapse of social control when the guards and others were given the prerogative to carry out netsa ermijja or instantaneous execution without any pretence at judicial procedures. Those who were armed by the Dergue thus became guards, judges and executors all in one. By 1977 Ethiopian society had arrived at a juncture which was characterized by normlessness, a juncture where the old legal system no longer functioned, but had not yet been replaced by a new one.

The situation allowed the new regime to purge not only the EPRP but also intellectuals considered potential political opponents. A former prison inmate and university lecturer reported,

...the prisons in Ethiopia are filled with intellectuals. In the room where I stayed as a prisoner, Room No. 7, about $98 \%$ can read and write and $90 \%$ have completed high school. Many of them are professionals. In the middle of November, there were nine doctors at that one police station six of whom were medical doctors ... There are several university lecturers and young men with masters and bachelors degree, some of them with several years of experience lingering in the prison (Bekele, 1980).

The argument of the Dergue and its supporters was that political violence was a by-product of a revolution and an essential component ${ }^{6}$ thereof. But it is difficult to see an end that can justify the excesses of the "Red Terror". Initially, the urban centres were severely affected and thousands of families were deprived of their children and bread-winners. Young men and women left the country en masse, the majority on foot. This was the beginning of the exodus of the educated élite from Ethiopia, thereby depriving the country of its skilled manpower and depressing the 
possibilities for sustained social and economic development ${ }^{7}$. Many of those who fled had experienced the "Red Terror" directly: they were imprisoned, some of them tortured and released, whereupon they fled. The following is an account by one such refugee of how arrests were conducted in the middle of the "Red Terror" period.

As I was driving down Churchill Road a white volkswagen ahead of me came suddenly to a stop just as it caught up with a well-dressed man walking parallel to the drive-way . . . Two men jumped out of the car and approached the man. In a matter of few seconds the man was handcuffed and shoved into the waiting car and driven away. I could guess what would follow. The man had started his journey to foul overcrowded cells, interrogationsaccompanied by the most atrocious tortures, long periods of imprisonment or finally facing the firing squad. The family too would have its share of mental torture. It would take them a minimum of a week to find the one jail out of the hundreds that exists in the capital wherein the man was held (Bekele, 1980).

This man was arrested on the street perhaps while on his way to work. Others were arrested by soldiers who stormed their work places, dragged them on board army jeeps at gun-point, and drove them to unknown destinations. Another cause for widespread anxiety at that time was as follows:

the militia may rudely knock on your gate with rifle butts at 3:00 in the morning. The way it is done awakens you to the realization that they have come either for you or your child or your wife. Or you are called to the Kebele Office by telephone to discuss some seemingly innocent matter and find yourself under arrest upon your arrival. In one or other manner the Damocles sword of arrest hangs over the head of every citizen (ibid.)

\section{Expansion of the apparatus of coercion and violence}

Pierre van den Berghe (1974:143) has suggested that the size and complexity of the state apparatus for the control of its subjects is a good index of its fear of counterviolence. It also implies the failure of the ruling class to indoctrinate the ruled. The nervousness and insecurity of the Dergue concerning counter-violence resulted in the development of an elaborate control and prison systems between 1976-1978. The curfew proclaimed at the outset of the revolution about thirteen years ago is still in effect; road blocks and checking points are erected on every motor road almost everywhere in the country. Travellers using private or public transport are searched indiscriminately at these points, and in the capital and the major towns visitors to public buildings, stores, banks, hotels and restaurants are regularly body-searched at the entrance. These routines continue in spite of the fact that the population, particularly in the urban areas, has been disarmed and is closely watched by the kebeles and hosts of security agents and informers. This gives the impression of a perpetual siege which has created a flight psychosis even among those who are not politically conscious or motivated. ${ }^{8}$

Another indicator of the ubiquitous political control and repression is the extensive system of prisons that exist in the country. Before the revolution there were perhaps (our estimate) about 800 to 1000 prisons and places of detention for all types of offences in the 14 taqlay gizats (regions), 100 awrajas (provinces) and 660 woredas (districts) into which the empire was divided. Following the military take-over, the number of prisons and prisoners proliferated. Places of detention increased at least tenfold when the kebele and peasant associations were proclaimed and given power to have their own local tribunals and prisons (Proclamations Nos. 47 and 71 of 1975). 
About 2000 kebeles and 23,497 peasant associations were established throughout the country (Griffin \& Hay, 1985:53).

The local tribunals of these associations were empowered inter alia with the right to impose fines, sentences of imprisonment up to three months and hard labour up to 15 days (POMOA,1977:38). Thus the kebele and peasant associations were able to get a firm grip over the population in their respective areas. In the urban areas the kebeles kept strict surveillance over citizens through registration of households, identity cards, roll-calls at compulsory weekly meetings and frequent public demonstrations.

The peasant associations also had specific powers to control the rural population through their militia. Population movement was controlled through a pass system, whereby everyone was required to have written permission to leave the village from officials of the local association.

It would be wrong to focus only on the repressive functions of these associations, particularly the peasant associations, without mentioning the democratic and positive contributions they initially made to political change.

At the beginning the peasant associations were concerned mainly with the social and economic (distribution of land, etc.) affairs of their communities. They naturally participated in the struggle against the feudal landlords whose holdings they distributed among their former tenants. At that stage they were autonomous bodies and gave peasant communities, particularly in the south, a new social identity based on equality and self-determination. Helped by the zemecha students the associations were able to build a new social structure that replaced the old oppressive feudal order. In short the peasant associations began as the instruments of the peasantry, transmitting their political will to the government. However, this did not continue for long since it involved conflicts of interest between the Dergue and the peasantry. The autonomy of the peasant associations was gradually undermined as they were institutionalized by the proclamation of the consolidation of Peasant Associations Bill of December 1975 and made subordinate extensions of the Ministry of Interior. Rene Lefort wrote that:

The institutionalization of the peasant associations was more to serve the state, allowing it to reach into the daily life of the countryside, than to make it possible for the peasant communities even gradually to take over the levers of administration (1981:124).

The peasant associations thus became an extension of the coercive arm of the state. They were used extensively for detaining and punishing those suspected of opposition to the regime, for the extraction of economic surplus, forced labour and for recruitment to the people's militia.

Several factors made imprisonment a most dreaded encounter in the post-revolution period. Summary execution without trial and torture to acquire information about the opposition were reported to be quite frequent. Indefinite detention without charge was common particularly in urban areas during the "Red Terror". The conditions in the prisons were nauseous. According to a former inmate, the cells were overcrowded to such an extent that 85 persons were crammed into a room measuring only 16 square metres. Lack of ventilation, heat, fleas and bugs, the unceasing moan and lamentation of prisoners who have been subjected to torture, the smell from untreated wounds inflicted by torture, etc. made prison life unbearable (Bekele 1980:45-46). In addition, the prisons lacked sanitary facilities. 
The government does not provide food in most of the prisons and wherever it is provided its quantity and quality are insufficient to keep a person alive. Relatives who live nearby and who can afford it bring prisoners their daily food. According to former inmates and other sources including Amnesty International (1983:34) medical treatment is either denied or when offered very inadequate. Such conditions drove many parents to panic and they persuaded their children to leave the country even if this meant indefinite return. Families sold their property and, during the "Red Terror" even their houses, to pay exorbitant fees to guides who could lead a threatened son or daughter through deserts and wild terrain to one of the neighbouring countries. The nightmare of the "Red Terror" is over but still, ten years later, this type of refugee continues to arrive in the neighbouring countries in significant numbers.

\section{Armed conflicts}

Political violence is not confined to the urban areas but also occurs in the countryside in different forms. Here conflicts between the armed opposition and the government forces are the main sources of violence, and they affect an ever-increasing percentage of the population. Nearly 38 percent of the respondents gave "living in war zone" as the major reason for their flightfrom home. War has a multiple effect upon a community. It dislocates existing relations and patterns, destroys property and reduces the possibility of economic and social survival. Thus if we take into consideration those who gave destruction of property due to war and conscription as one of the reasons for flight we find that war accounts for the displacement of about 50 per cent of the respondents. The percentage of those fleeing Ethiopia because of war would be even greater among refugees in Somalia since the Ogaden war and the war against the Oromo and Sidama Liberation Fronts have uprooted thousands of peasants and nomads from the regions of Bale, Hararghe and Sidamo.

\section{Solving political conflicts with military means: The dramatic increase of war zones}

a. The Northern Fronts. War zones increased dramatically in area after 1974. In 1975 anti-government groups increased in Wallo, Gondar and Tigray and formed various fronts including the Ethiopian Democratic Union (EDU) which was led by the members of the fallen regime. There were several clashes, such as the war of 1977 around the town of Humera between the EDU and the Dergue, which drove the inhabitants of Humera and surrounding farms across the border into Sudan en rnasse. Most of these people ended up in the refugee camps of Um Rakoba, Tenedba, Tawawa and Um Gulja which together sheltered approximately 30,000 refugees at the time of our survey. Farther west, in the rugged mountains of Tigray, the war which broke out between the TPLF and the Dergue, the TPLF and the EDU over the control of the area and later between the TPLF and the Ethiopian People's Revolutionary Party (EPRP) contributed to the stream of refugees. When the TPLF emerged victorious in both cases, it threw the EDU and EPRP out of the province. Many of their members later turned up in the Sudan seeking asylum.

With the failure of half-hearted efforts for the peaceful solution of the conflict in 
Map 6. Areas of conflict between nationalist movements and government forces

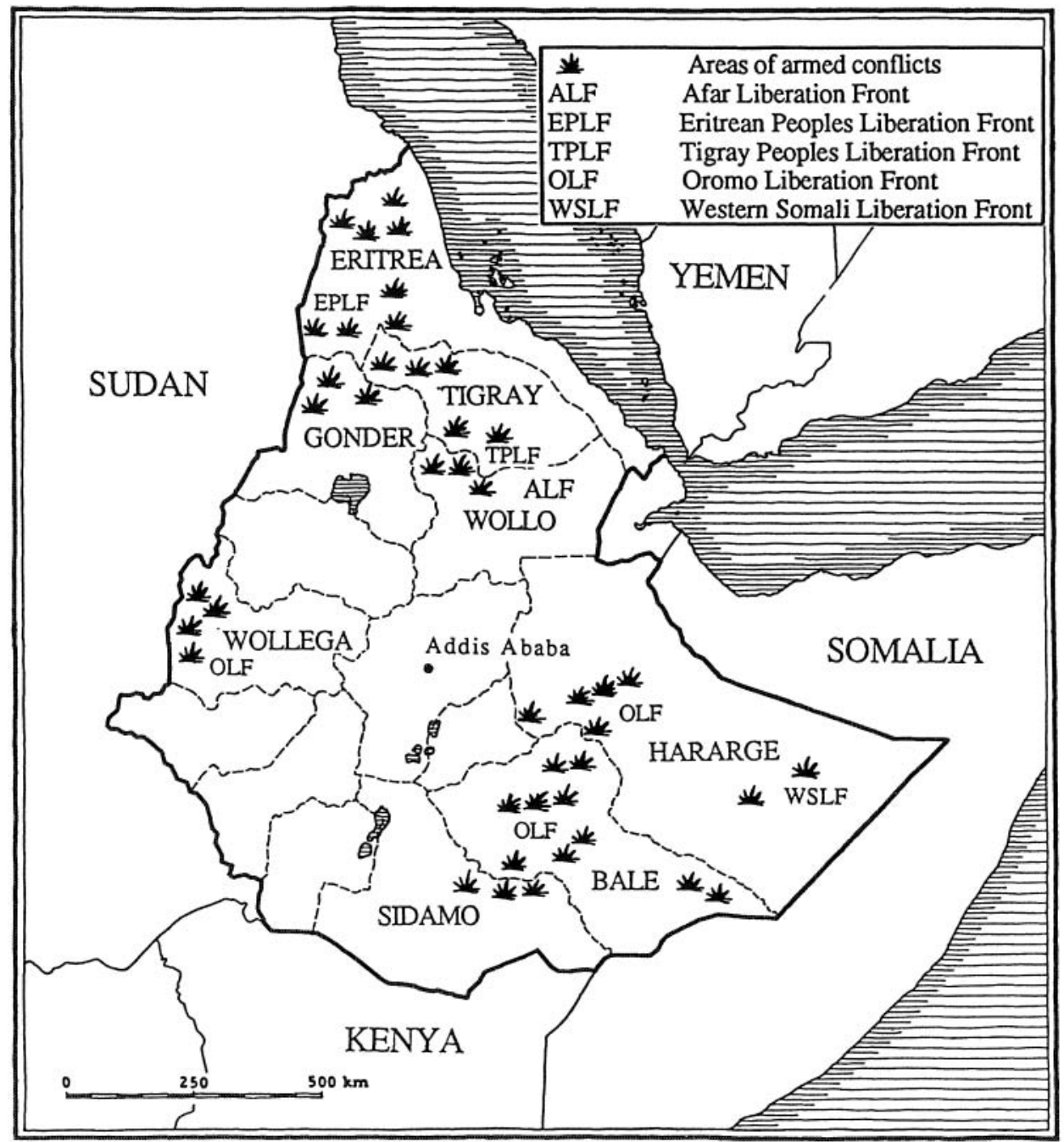

1976, the war escalated in Eritrea and the guerrilla forces succeeded in gaining control of the entire countryside. By 1977 only the capital city of Asmara, the ports of Massawa and Assab and a few small towns remained in the hands of the Dergue. Bitter battles were fought for months in and around these urban centres. Many of their inhabitants managed to escape from the beleagured cities and fled into the Sudan or crossed the Red Sea to the Arabian Peninsula.

b. The Somali and Oromo regions. The situation in the south and southeast was no less dramatic. The Ogaden was overrun by the Somali regular forces in 1977 . The military violence unleashed against the local population in this area and the neighbouring Oromo provinces was unrestricted. The invading forces and the retreating Ethiopian troops complemented each other in destroying towns and human settlements, wells, herds and farms in the vast semi-desert (Braukamper, 1982:5). Hun- 
dreds of thousands of its inhabitants fled south and east and came to Somalia. In 1978, with the help of massive external involvement, Ethiopia regained the upperhand and the Somali forces were defeated. The nomadic population of the area, fearing repression from the Ethiopian forces followed the retreating Somali army into the Republic of Somalia packing the refugee camps to unmanageable proportions.

The conflict between the Somali and Ethiopian forces affected not only the Somali-speaking population of the Ogaden but also the Oromo. The Oromo peasants of Hararghe, Bale and Sidamo regions suffered severely from violence perpetrated against them by both the invading Somali troops and the Ethiopian forces. The Somali soldiers looted and destroyed Oromo property, molested and killed people and claimed their lands (cf. Gellner, 1983:84). The Ethiopian forces suspecting the Oromo of siding with the Somalis, treated them with similar repressive measures.

Sandwiched between the two forces and repeatedly and indiscriminatelyattacked, the Oromo peasants had no alternative to fleeing their homes. Young men joined the Oromo Liberation Front (OLF) while their families sought refuge in areas controlled by it. The OLF grew in size due to this influx and expanded its activitiesinto several districts in Hararghe, Bale and Sidamo. At this time a smaller movement known as the Sidama Liberation Front (SLF) was formed in the central highlands of Sidamo and joined the armed struggle against the military government.

After its victory over the Somalis in the Ogaden in 1978, the Dergue directed a series of "mop-up" operations in the Oromo and Sidama areas where the OLF and the SLF were active. As the result of these operations villages were burnt and their inhabitants were summarily "punished" in an attempt to destroy the nationalist movements and discourage potential sympathizers. Quoting several sources, Ulrich Braukamper (1982:5) noted that Ethiopian troops carried military offensives in the Oromo areas of Bale province in 1978, October 1979 and February 1980 causing heavy damage and casualties. He added that about 400 women and children were killed in an air raid near Ginir in 1980. According to one report the Ethiopian air force bombarded villages in the Guji inhabited Jamjam in March 1981:

All life, including the vegetation was burnt up in this large valley in the Worencha district of Sidamo province. Usually, 20-30,000 people live in this fertile and productive valley. Many people fled from the area as the rumour of the attack was heard. Thousands of people were killed in the attack. ${ }^{9}$

We could not ascertain the reliability of this report. Nevertheless, there is sufficient evidence that it was the stepping up of military activities in these areas which subsequently led to the giganticincrease in the flood of the refugees to Somalia: from 100,000 in 1978 to about 1.5 million $^{10}$ in 1981 . The majority of these were Somalis from the Ogaden and the rest (about 40\%) were Oromos from the adjacent regions (cf. Waldron, 1983: 17-24). Since the middle of 1985 the proportion of Oromo has been increasing.

Conflict spread also to other areas such as the Afar lowlands in the northeast and the Gambella districts of the southwest. The Afar Liberation Front (ALF) and the Gambella Peoples Liberation Movement (GPLM) waged armed struggle against the central government in Addis Ababa. These hostilities produced Afar and Anuak refugees. 


\section{Military conscription}

In order to face the ever-rising opposition from the various nationalist movements and other groups the Dergue relys heavily on a militia force which it has maintained through mass-conscripting until very recently.

\section{The peasant march on Eritrea}

The first large militia conscription started in mid May 1976 when the "Peasant March" on Eritrea was conducted. Having failed to persuade the Eritrean Liberation movements to lay down arms with promises of regional autonomy (POMOA, 1977: 161-165), the Dergue launched its new militia force into attack in Eritrea. The adventure proved disastrous for those who were directly involved. These peasants who were sent to Eritrea were conscripted from the three northern provinces of Gondar, Tigre and Wollo. The majority of them were from Wollo and Tigre, two regions which were just recuperating from the devastating drought and famine of 1973-74 which claimed around 200,000 lives and wiped out 90 per cent of the livestock. A significant proportion of the tens of thousands of men to be sent on this fateful march had just recently returned to their villages and were busy rebuilding their houses and lives after two or three years in relief shelters provided by the Ethiopian Relief and Rehabilitation Commission (RRC) and the international community. They were in the middle of planting their (in most cases first) crops when the call came. In terms of agricultural production this was a severe blow since those who were conscripted were able-bodied men, often heads of families. For those communities which were just recovering from the effects of years of severe malnutrition the conscription of their active work force prolonged the famine. The next season agricultural production was very low in Wollo and Tigray regions in spite of sufficient summer rains. Famine was reported in several districts and food assistance raised abroad had to be distributed when people started to appear again in the towns where they had been shelter inmates just a year or two previously.

The consequences of the peasant march were even more tragic for the individual peasants involved. The march was poorly organized and on the Wollo-Tigre road the lorry loads of peasants equipped with old rifles and led by small groups of military or police escorts" were deciminated before reaching the frontlines by the guerrilla fighters of the various fronts operating in northern Ethiopia. In the face of total extinction, a retreat was made in complete disorder. The majority of the militiamen who survived the slaughter made their way back home by foot, begging for food and shelter along the way. Those who gave up themselves up to the guerrillas were released about a year later and returned home or continued their journey westward to the Sudan to join the swelling refugee population in that country. Those who returned to their home villages after a year of absence were not particularly welcomed by the authorities and some of them were put into custody lest they would spread information about the guerrillas and the conditions in the fronts which might affect the recruitment of new fighters.

The conscription of militia forces continued in the summer of 1977. More than 500,000 (PMAC, 1977) were recruited that year mostly from among the Oromo and other peoples in the southern regions. From the time of the Ogaden war the militia 
had been given short training courses and were also better armed as the result of a massive supply of weapons from the Soviet Union. Both in the Ogaden and in the north, the militia were seen as an inexhaustible source of fighters. According to our informants who deserted from the northern fronts, tens of thousands of youngsters between 18 and 25 years were literally used as cannon-fodder. The Dergue's tactic in its armed confrontations with its adversaries was to overwhelm them by sheer numbers. This generally resulted in a catastrophe for the militia since they were mown down in thousands in every battlefield. One of the respondents reported that

When we came to one large dry valley in the Sahel we saw human skeletons scattered all over the place. The skeletons were more numerous than the stones in this semi-desert. We learnt that the skeletons were of the militia who were ambushed by the guerrilla fighters. I thought it would not be long before I become one of the skeletons if I stayed at the front. So I talked to two boys from my village who were in my unit and we decided to escape. But we had to wait for a week or so and when my turn came to guard our camp at night we deserted and went over to the EPLF which gave us a guide to the Sudan border.

\section{Poverty as Cause of Flight}

About 20 per cent of the respondents mentioned poverty as one of the main reasons behind their flight to the Sudan. Taking their motives at face value we may classify these persons as economic refugees. However, since in the majority of cases poverty was the result of government policies it may not be correct to categorize them in that way. Even though the apparent cause of flight was economic, it was political factors that mainly accounted for the situation. This is not to deny the presence of economic migrants among the refugee population in the Sudan. But since our survey was conducted before the 1984-85 famine which sent tens of thousands of refugees from northern Ethiopia to the Sudan, the number of respondents who mentioned natural disaster such as drought as the cause of their flight was very small. The poverty, according to respondents, was the result of government policies. The respondents frequently mentioned (a) military conscription; (b) heavy taxation and forced contributions; (c) political meetings and forced labour as the direct cause of the impoverishment of their households.

Contributions are made not only for military ends. In fact, respondents mentioned a long list of taxes and compulsory contributions which they identified as the main cause of their poverty. Some of the most frequent ones were "contributions for the literacy campaign", contributions for the "defence of the motherland", "zemecha contributions", kebele and peasant association contributions", "development contributions", "resettlement contributions" and "contributions for drought affected regions". According to one report based on interviews with refugees, there are as many as 17 types of compulsory contributions collected by the Ethiopian state and various state-organized mass associations (Holcomb, 1985). Steingraber (1987) has indicated that the number and size of the contributions demanded are increasing, and are not adjusted to households incomes.

There is no exemption from these contributions and failure to pay according to respondents, resulted almost always in imprisonment and fines. Therefore, respondents sold the little they owned - oxen, corrugated-iron torn from the roofs of their 
houses and, according to Steingraber even their clothes and doors from their huts to pay the contributions. The respondents in our study had fled to avoid imprisonment since they were unable to pay. It should be mentioned here that the main cause of poverty in Ethiopia is underdevelopment; the heavy taxes and compulsory contributions imposed by the present regime have only exacerbated this situation. In addition to these dues, confiscation of property by the government was also mentioned as a cause of poverty and flight.

Drought is a cyclical phenomenon in Ethiopia and, since rain is almost always uncertain in some regions the peasantry store surplus when available to safeguard against poor years. The heavy dues imposed by the present regime have undermined this practice, thereby exacerbating the consequences of drought. The absorption of the labour force into the militia and the material contributions extracted have lowered food production even daring periods of normal rainfall and in relatively fertile regions. Another policy which has seriously affected food production concerns the Dergue's control of the market for agricultural products. In order to control the supply of agricultural goods and to ensure the flow of food products to urban areas, a state-run organization called the Agricultural Marketing Corporation (AMC) was created. It is obligatory that each peasant household sells a certain, fixed amount of its produce to the AMC. The prices that the AMC offers, according to our respondents and other sources (see Clay \& Holcomb, 1985:109; Getu, 1987:129) are often half, or less than half, of the market value of the delivered goods. The fixed quota assigned is sometimes more than what the peasants are able to produce. But since delivery is obligatory, the respondents told us that they had even borrowed grain to fill their quotas. In general this and other policies created not only resentment but also lowered production by creating disincentives.

The various political meetings which the peasants are obliged to attend also contributed significantly to a decrease in production, the general impoverishment of the rural population and above all the perpetuation of famine. Respondents told us that they spent on the average about a day or two every week at the meetings organized by the cadres and the peasant associations. Sometimes the meetings were so frequent that they were unable to sow or harvest. The cadres gathered the peasants to explain the various proclamations and communiques which the Dergue issued. Meetings were called to discuss the contributions to be made by the peasants, the recruitment of the militia, to organize rallies or to celebrate holidays introduced by the new regime. While these peasants attended the numerous meetings their harvests rotted in the fields, their farms were overgrown by weeds and their crops were destroyed by wild animals.

It is natural that the hopes aroused by the revolution were dashed when the peasantry were faced by these situations, and that many of them fled to neighbouring countries. What is most remarkable here is the insensitivity or perhaps ignorance of officials regarding the conditions of production in rural areas. Most of the former feudal lords were more judicious in their exploitation of the peasantry. Unlike the Dergue's cadres they were rather careful not to destroy the source of their dues. They did not often force their tenants to sell their oxen and other means of production in order to collect rents. They postponed the date of collection until the next season, thereby ensuring the survival of the peasant producer and of course the source of their income. 
The insensitivity of the cadres and the deleterious consequences of the policies they implemented can be accounted for primarily by two factors.

Firstly, since they are government employees these cadres are not directly affected by failures in peasant production. But failure to implement policies passed down from their superiors has direct repercussions for them. Their promotion in rank and salary is dependent on their ability to implement government policies. Those who fail to do so are considered "counter-revolutionary" and are demoted or punished. Consequently, it is not unusual that bureaucrats and cadres at the different levels of the administrative hierarchy carry out orders knowing their negative consequences both for individuals and the society. Some officials may also be implementing inexpedient policies because they believe that this is the most effective way to discredit the regime. Our observations in the early days of the post-revolution period and interviews with government officials indicated that the above practices are not uncommon.

The second, and perhaps the most important, factor that renders the Dergue's policies counter-productive is the lack of experience and training of their implementors. Because of the loss of intellectuals and experienced technocrats during the "Red Terror", the regime has had to rely on less well-educated and experienced technocrats for the implementation of policies. Key positions are often given to the military and unskilled political cadres.

In spite of the organization of the rural and urban populations in various associations their participation in decisions affecting their lives is spurious. Hence possibilities to influence government policies at the initiation or implementation stages are very limited. The masses were left with two alternatives in this situation: silent obedience, or flight to areas controlled by liberation movements or the neighbouring countries.

\section{Large-Scale Implementation of Forced Labour as a Direct Cause of Flight}

Landlords and functionaries of the state have extracted unpaid labour from the peasants in different forms for many centuries in Ethiopia. The gabbar system which was discussed in Chapter 2 was based on the surplus that the landlords and the employees of the state extracted from thegabbars as pure labour or labour products. The state extracted corvee labour in the form of hudad from the peasantry. The revolution did not bring about an end to forced labour. After the revolution people were not only required to pay compulsory dues but were also obliged to provide free labour for various activities. They cultivate, sow, weed and harvest the fields of tens of thousands of families and widows whose men were recruited to the militia, work on state farms and provide labour to various activities organized by the kebeles and peasant associations. While they keep the peasants away from their own family plots, most of these activities bring them very little direct or indirect benefit. Resentment is therefore widespread. People are unwilling to work freely for the state but are coerced by the authorities to do so.

The implementation of forced labour on a large scale is related to the deterioration 
of economic conditions and state revenues between 1975 and 1980. The loss of skilled manpower during the "Red Terror" crippled industrial production and disrupted transport causing severe shortages of food and consumer goods all over the country. The large arms bill and rapidly deteriorating conditions of foreign exchange had brought the Ethiopian economy into serious straights. In an attempt to bring the economy out of this crisis, boost exports and improve state revenues the Dergue decided to expand the state farms sector which was created with the nationalization of rural land in 1975. In the beginning the sector consisted of nationalized commercial farms but was increased by about 300 per cent (Griffin and Hay, 1985:54). These state latifundia were far from being profitable and were run at enormous losses due to managerial and spare part problems. The income from those farms was not even sufficient to pay for the seasonal labour required for harvesting and the Dergue reported during the 1977-78 harvest that crops worth Birr 80 million had been left to rot in the field (Legum and Lee, 1979:62). It was at this juncture that the use of coerced labour on state farms took enormous proportions. The Humera state farms are a good example. Forced labour was used on an extensive scale and about 12 per cent of our respondents gave this as the reason behind their flight. Labourers were recruited both from the urban areas and the villages. The method employed was in some respects similar to that used in militia recruitment. In the towns government officials toured the kebeles calling for volunteers. But the number of those who volunteered was very small and, therefore, men and women between the ages of 15 and 65 had to be press-ganged by kebele guards. In the countryside, labourers were recruited by the peasant associations which were usually given quotas.

The length of service required from the recruits varied depending upon the location of the farms. In Wollega it ranged from a couple of days for most recruits to several months for those who were recruited in urban areas and lacked kebele identity cards. In Humera a longer period of service of a year or more was enforced. In the meantime the labourers were not allowed to return home for family visits.

\section{Some consequences of forced labour}

Flight is a reaction to the methods used in recruitment and the treatment experienced during transportation and at the work sites. The labour recruits were escorted by the military in convoys which took several days to reach the labour camps from their villages and towns. The recruits were transported under very difficult conditions, without proper food or sleep. As a report from the Anti-Slavery Society (ASS) from 1979 indicated:

The first (convoy) left on July 8th 1980. 3,990 people were crammed in 59 trucks, built to take 35-40 each. They were forced to sit in a squatting position, covered by a sheet of canvas which was suspended like a tent over them. Each truck was guarded by an officer and 2 soldiers in the driver's cabin. No one had any food or belongings, as even their shoes had been confiscated at Tatak . . . They reached Gondar on 13th of July. They were kept in the trucks all night. Many were already weak and sick . . . The first convoy reached Humera on the 16th of July. Many were suffering from pneumonia and other sicknesses. They were starving, poorly clothed and severely crowded (ASS, 1979).

The problems faced by the recruits during the journey are difficult to conceive for some one who did not experience them. Respondents who were transported in this manner for days told us that the crowded conditions, and the canvas with which the 
trucks were covered made the trucks hot and suffocating. They said that there were casualities due to suffocation and lack of treatment ${ }^{\mathrm{L} 2}$. Respondents also reported that the living conditions on the farms were hardly bearable. There were no houses and on their arrival they were made to sleep in the open air. Those who were strong gathered wood and grass and gradually built themselves shelters against the sun. Other reports support respondent descriptions of the housing conditions in Humera.

No proper houses could be built, so later during the rains, many suffered from flooding. After the rains many suffered from infections (blisters) which subsequently caused some deaths and much suffering amongst young women. These young women were unable to build their houses and were forced to live with men. Many were raped and became pregnant ... (ASS. 1979).

The food rations which the workers received for their labour could barely keep them alive. Respondents told us that a cup of flour a day and sometimes a cup of beans and a spoon of salt was distributed per person. Occasionally milk prepared from milkpowder donated by international organizations to drought-affected areas was distributed as supplement. Similar hardships were also experienced by those who were uprooted from Wollo and Tigray and resettled in Wollega.

Water was very scarce in Humera and sometimes not available at all when the water-tankers did not come. Contaminated water was thus consumed, causing dysentry and other water-borne diseases in often epidemic proportions. The scarcity of food, lack of proper shelter and medical facilities, combined with the hot lowland weather conditions to which the majority of these highlanders are unused, caused sickness to which thousands succumbed at the Humera and Assosa state farms and settlement schemes. Some of the escapees from Humera that we interviewed referred to the labour camps as "death camps". We do not know how far this information is reliable but interviews with different individuals at different places and times are strikingly similar. Studies conducted among refugees in the Sudan between 1978 and 1987 has unearthed similar experiences. The Anti-Slavery Society reported:

Because of the large numbers dying the government set up a Task Force chosen from the people (the workers at Humera) whose job it was to bury the dead. I was chosen from one group. There were 2,500 people in my group settlement from which about 500 died . . .320 crossed over to the Sudan . . . very soon alarge percentage had died or fled to Sudan (ASS, 1979).

\section{Flight to the Sudan}

Respondents told us that they chose to flee to the Sudan because of the lack of any other alternative. They did not have money to pay their way back home. It was impossible to walk home as the distance to be covered was often great. When that was possible there was little chance of going through the several check-points along the road without official papers. At first the labourers escaped across the border in small groups. The success of those who left first encouraged others to flee in larger and larger numbers. There were even several who went back to the farms and helped others escape. Thus the state farms made a significant contribution to the flow of refugees out of Ethiopia. According to the ASS report cited above, of the 17,983 people who crossed into the Sudan in 1981 about 90 per cent came from Humera. A UNHCR report indicates that of a sample of 100 asylum seekers who turned up at the 
UNHCR headquarters in Gedaref between May 10 and 31, 1982, 30 were escapees from labour camps (UNHCR, 1982b). What is most striking about this group is that they originate from widely scattered parts of Ethiopia. The findings are corroborated by an official report of the Dergue which stated that of the 37,805 workers engaged in Humera in 1980 only 1,125 had lived in the area. The rest were recruited from the regions of Gonder, Gojjam, Wollo and Addis Ababa (see Ethiopian Herald, October 12, 1980).

\section{Mass Relocation: a Contributory Factor to Refugee Flows}

One of the reasons given by our respondents for their flight from Ethiopia is relocation. Carried out under the two programme of "resettlement" and "villagization" forced relocation has become one of the main refugee generating factors (Billard, 1986: 27-28).

Before embarking on the discussion of the relations between refugee flows and the relocation programmes of the Ethiopian government we shall make some general observations regarding the concept of relocation and the socio-politicaland sociological issues which it raises.

By relocation we mean the forced movement or displacement of a population or population groups within the same country. Other writers (see Oliver-Smith and Hansen, 1982) also regard movements across international boundaries as relocation. Relocation is seldom voluntary and relocatees are almost always coerced socially, politically or economically to settle in places determined by others. It is an involuntary migration connected with social organization that controls and overpowers individuals and groups and directs their movement in one way or another (OliverSmith and Hansen, 1982:1).

Relocation is a widespread phenomenon, carried out by all types of governments, and is aimed to achieve a variety of ends. In some countries it is concerned with the welfare of the population or groups targeted. Some governments relocate communities for political ends that serve primarily the interests of the state or a dominant section, often a minority, within society. The apartheid system of South Africa with its Bantustan or "homeland" policy is an extreme case.

Whatever the aims of the state, relocation generally affects the most deprived sections of society. Urban renewal programmes affect mainly slum and shanty-town dwellers, development projects such as dams, hydroelectric power stations, and highways displace the powerless. In several Third World countries, including Ethiopia under the former regime, the introduction of capitalist agriculture displaces peasants and pastoralists. Minorities such as the Indians in North America and the Aborigines in Australia are displaced or relocated when valuable natural resources are discovered in their home areas.

Relocation is also carried out by governments for strategic purpose. The British and the Americans regrouped Indo-Chinese peasants into 'protected' villages during the 1950s and the 1960s in order to isolate nationalist movements. The Portuguese did the same in their former African colonies as a strategy to suppress anti-colonial 
movements. Thus forced relocation infringes on the basic rights of individuals and often constitutes gross violation of human rights.

The execution of relocation necessitates governmental power to enforce the move and the availability of support and/or control structures to ensure that people remain in the new location. The first determines whether relocation takes place and the second concerns mainly to what extent it can be sustained. This in turn depends, inter alia, upon the living conditions, and the existence of infrastructural support to help relocatees adapt to the new environment, particularly when the aim of relocation is developmental. In the case where control is the objective, sustenance of the new settlement depends on the ability of the government to stop relocatees from leaving.

Most governments have coercive resources to enforce the relocation of disadvantaged sections of their subjects but it is only a few of them that are able or even ready to provide the needed support structure for the sustenance of the groups they relocate. Hence, relocatees usually face dire problems and resettlement schemes are seldom crowned with success (Palacio, 1983; Oliver-Smith 1983; Khera and Mariella, 1983). Whatever the official aims may be, the response of target groups to relocation is almost always resistance. Such resistance often reflects an essentially conservative attitude to uprooting as well as the problem of the cognitive restructuring that will be needed to adapt to the new environment. The intensity of resistance to relocation depends inter alia upon the relative strength and status of the target population in the wider society, the similarity between the new and the old environment and the degree of coercion and voluntariness involved in the process.

\section{Current Mass Relocation in Ethiopia}

The Ethiopian military government has carried out an extensive operation to move individuals and whole communities from their original homes to new localities since 1976 under two different programmes known as "resettlement" and "villagization". Resettlement concerns mainly the relocation of peasants from north Ethiopia to the south and south-western parts of the country. As such it is a long-distance movement, covering hundreds of kilometres. The distance is not only spatial but also socio-cultural and ecological. Resettlement has also involved the sedentarization of nomadic population and the removal of lumpen proletariats from urban centres to rural agricultural schemes. In fact the Settlement Authority's target in 1976-77 were specifically these two groups. But very few of these have been resettled so far. On the contrary, about one million peasants have been transferred from northern Ethiopia to the south since $1979 .{ }^{13}$ The Dergue's plan is to resettle between 200,000-300,000 people from the north in the south between 1987 and 89, and the operation is now under way. Villagization is short-distance relocation. In the beginning the operation was limited to the south, particularly to Oromo peasants. Oromo regions like Arsi and Hararghe were almost totally 'villagized' by the end of 1986. Today (November 1987) about 7 million peasants have been regrouped in hastily constructed villages all over the southern and central regions. According to officials of the Ethiopian government quoted by various sources (Cohen and Isaksson 1987; Steingraber,1987; Clay \& Holcomb, 1986) about 30 million peasants are to be 'villagized' before 1990 throughout the country. 


\section{Objectives of resettlement}

The official version. The officially declared objective of the resettlement programme is to enable drought-affected peasants from the north to become economically self-sufficient through their relocation in the more fertile regions of the south. Those who were relocated were promised fertile land, food, clothing and services. The services promised, according to some respondents, even included electricity in their villages and homes. Promises aside, the Dergue did not have any budget nor the means to cover the formidable costs of transporting, feeding and settling the 1.5 million that it originally planned to relocate through this programme. It envisaged, however, sources for financing the operation: international aid, both humanitarian and development assistance, and the material contributions from the local population which we discussed above.

There is no evidence that the -resettled communities can become economically self-sufficientin the near future. The Ethiopian economy totally lacks the capacity to support such a huge operation. The remaining possible source of funding is foreign aid. However, because of the coercion used to move the settlers and the massive criticism that the resettlement programme as a whole has received from the mass media, very few aid agencies have so far been willing to get involved. Nevertheless, it is difficult to see how long they will be able to steer clear of involvement because, given the size of the relocation programme it may soon become difficult to give any development aid without helping these schemes. The programme was carried out in its present form from 1979 but was discontinued in 1981 due to resistance from the relocatees and the local population at the site of the resettlement schemes, negative international public opinion and lack of resources. It was resumed in 1985 on a very large scale and during that year alone about 600,000 peasants from Wollo and Tigre were relocated in south-western Ethiopia. Three conditions made the resumption of the operation on such a large scale possible. Primarily it was justified even in the eyes of the international public by the severe drought which hit the country.

It is argued by the military government that the only lasting solution to the famine problem is the relocation of the famine victims to the south where land is abundant and rainfall is sufficient. However, neither land nor rainfall is abundant in the provinces to which these people were relocated, and the indigenous peoples were dying of starvation at the same time. Secondly, famine drastically weakened the resistance of the target population to relocation. They became easy victims for manipulation because of their dependence on grain doled out by the government Relief and Rehabilitation Commission (RRC). The famine victims came to shelters in search of food and were easily persuaded, or coerced to climb trucks, buses and even aircraft heading for the south-west. ${ }^{14}$ Thirdly, and most important of all was the availability of substantial international humanitarian aid which the government was able to use to implement the massive relocation.

The famine and the sympathetic international opinion provided a good opportunity for the Dergue to carry out the villagization and resettlement operations simultaneously. Although not as old as resettlement, villagization is neither a new operation. It was carried out first in the Oromo province of Bale between 1979 and 1982. The official motivation for the operation was the provision of social services like water, health-care and education. Even villagization is being implemented with the idea that international relief aid might finance the services to be installed. 


\section{Other apparent objectives}

Control. Even if resettlement and villagization could be considered as outcomes of the developmental and ideological concerns of the military government there seem to be other motives which are equally important in the genesis of these programmes. These are control and national integration. The importance of settlement schemes as a means of control becomes apparent when the target population and the location of such schemes are carefully studied. At the very beginning the main targets of the resettlement programme were the urban unemployed and army personnel opposed to the government (Wood, 1983:531). The removal of these discontented and potentially disruptive elements into the countryside was considered the most effective method of controlling them. The operation was extended to the semi-nomadic population of the Ogaden in 1976-77. At that time these people were not only severely affected by drought but had also been infiltrated by the West Somali Liberation Front (WSLF), whose fighting forces were gaining on Ethiopian forces in the area at a very rapid pace. The concern of the government to insulate the nomadic Somalis and isolate the insurgents was such that the relocation programme was continued and new settlers brought in to the Gode from a radius of about $150 \mathrm{kms}$, in spite of occasional heavy fighting around the settlement schemes in Gode and Gode West in 1977. In contrast, the Afar nomads who were in similar economic straights due to drought were not resettled at that time perhaps because there was no need to insulate them against insurgents. If not peaceful, the situation in the Afar areas was not as explosive as in the Ogaden.

The element of control in the relocation policy of the Ethiopian military government was crystallized by the regrouping of the peasants of the Bale highlands into villages in 1978-79. As we have already indicated, the province of Bale is one of the traditional bases of Oromo resistance to the Amhara government and remains so even today. In 1978-79, after the Dergue won the war over the Ogaden against the regular Somali army and the guerrillas af the WSLF, it carried out a major offensive against the OLF in Bale and the Chercher mountains of Hararghe. Following the offensive the local Oromo population was regrouped into several protected or 'development' villages. The area was the first to receive settlers from the north: between 120,000 and 150,000 people from Wollo and Tigray were relocated here. Several very large state farms were also opened in the area. The regrouping or 'villagization' of the local peasantry in a revolt-prone province like Bale fulfils several functions in the overall control and integration strategy of a minority government in a multi-national setting. More directly it helps reduce the collaboration between peasants and anti-government forces. As it could deny such forces economic and social bases regrouping is an instrument in fighting and eliminating them.

What is more, in areas like Bale where the local population is considered intractable or unreliable, a strong government presence is essential. But such a presence cannot be maintained effectively by stationing military units in the area which might also be needed in other parts of the country. It is here that we can see the interconnection between villagization (of locals) and resettlement (of outsiders). Regrouping the scattered settlements of the indigenous population into specific localities frees large tracts of land which the government is able to use as empowered by the Rural Lands Proclamation Bill of 1975 for whatever purpose it deems necessary. In Bale such land has been allocated for resettlement schemes and state farms. Since the settlers and often the farm-workers are from outside the region they are instrumental 
in breaking up the ethnic homogeneity of the indigenous people (see Melbaa, 1980:65; Wood, 1983:532).

Although the Amhara and Tigre who are the majority among those relocated in the south and the southwest are involuntary migrants and, as far as could be gathered from our interviews with the refugees, not always willing to be used as a government police force to watch over the local population, there are still some functional similarities between present resettlement schemes and the ketemas of the former periods. There are indications that some settlers particularly those relocated in 1979-82 were given rudimentary military training and provided with arms not only to protect themselves but to constitute a force of control in their areas (Wood, 1983; Triulzi,1983; Steingraber, 1987:65). The fact that the settlements are located mainly in Bale, Arsi and southwestern regions of Wollega and Illubabor where the OLF is militarily active and poses a security problem (The New African, No 217, 1985; Niggli, 1986:36) gives credibility to the argument that the settlement schemes have strategic and control functions (cf. Maps 6 and 7).

Forced integration or Amharization. The integrational functions of the resettlement programme seems also to be quite significant. Regarding the relocations in Bale an observer commented that,

...the Oromo are often dispossessed to make room for the incoming settlers and shifted to new sites to the east and extreme south in a kind of ethnic musicalchairs intended to forcibly integrate the diverse peoples in the context of a general "Amharization" of the Empire (Horn of Africa, Vol. 4, No.1, 1983:39).

During the previous regimes unity among the peoples in Ethiopia was not achieved because little effort was made to bring about their cohesion and integration. This is now being attempted by reshuffling the different peoples. The large-scale mixing of population that the resettlement policy entails will, no doubt, change the demographic characteristics of the various regions, break down "ethnic" homogeneity and most probably undermine nationalist sentiments and aspirations for autonomy or secession. Once the population, particularly those in conflict-prone regions, is sufficiently mixed with other elements demands for even national and regional autonomy will gradually become irrelevant, allowing present power relations between the state at the centre and the peripheries to continue unaltered.

Here, we should draw attention to the case of Asosa and Gambella, two awrajas in the southwest that have received the bulk of the settlers in the last few years. Already, in both awrajas, the indigenous population have become very small minorities in every sense. What is more significant is that these two awrajas were in September 1987 raised to kifle hager (regional) status. The two regions are now entirely Amharized: Amharic language and the Amhara culture which were rarely noticed here about ten years ago are now the dominant features. The Berta, Anuak and Oromo peoples have to adopt the language and culture of the majority. Their possibilityfor some sort of linguisticand cultural autonomy is now severely curtailed. Thus resettlement rules out any possibility of meaningful autonomy and strengthens the presence of the Amhara state in these regions with rebellious indigenous peoples who become reduced to a minority status, closely controlled by the settlers. The method is not new but was used repeatedly by Abyssinian kings against subjugated peoples (Triulzi, 1983: 125). The Dergue's policy towards the Oromo is particularly 


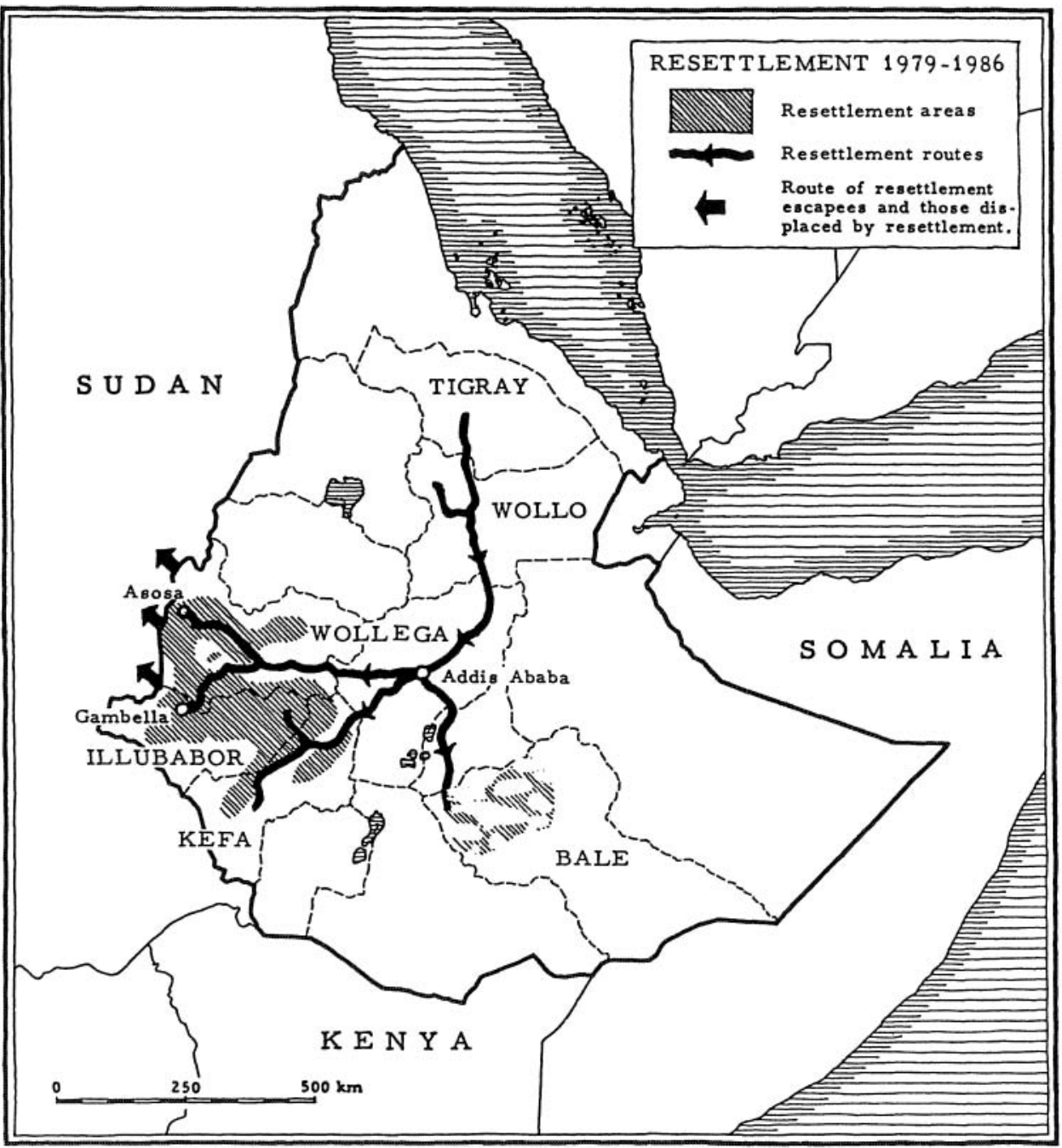

that of reshuffling them with the dominant Amhara. The exclusion of the Oromo from even the sort of autonomy which the Dergue promised some regions in September 1987 should be seen in relation to its resettlement policy.

\section{Responses to Relocation}

Resettlement is resented by those who are relocated because of the coercion involved, the social and psychological stress incurred in the process and the conditions experienced in the settlement. 
The indigenous peoples in the resettlement areas are opposed to the schemes because of the fears which they conjure up in their minds and the material burdens resettlement entails. Villagization is resented because it is imposed without the full consent of peasants and for the social and economic disruption it is said to be causing.

The massive nature of the resettlement programme necessitates a large amount of external assistance for its success. However, exogenous reactions to the Dergue's relocation programme are not very positive. Only a couple of the international organizations concerned with development and humanitarian aid are directly involved in the projects. In fact the criticisms regarding the manner in which the operations are conducted is massive. Several independent observers and researchers regard the settlement programme as (a) a gross violation of human rights; (b) a conflict exacerbating factor between the different nationalities in Ethiopia and (c) as a threat to the eco-system not only of the settlement areas but also of the whole region. We will discuss the points raised against resettlement by our respondents and others in the following sections.

\section{The predicaments of the relocated}

Interviews with refugees who flee from the resettlement schemes indicate that few of the relocatees are informed about the operation before they are put on trucks or buses to be moved to the south. They said that they were even rounded up at market places, while on the way to visit relatives living in towns or at funerals and taken to the new areas before even taking leave from their families. There are also those who were recruited by the peasant associations. Although the criterion used for such recruitment was meant to be poverty, it seems that relocation has been used by some of officials of the associations as a means to get rid of "trouble makers" or, according to one respondent, "to get at his land which happens to be the most fertile piece in the whole village". Even relocatees who were interviewed at the resettlement schemes (Oste, 1984) said that they were neither affected by drought nor famine when they were removed from Wollo in 1979 and resettled in Asosa. Our respondents also said that they left behind cattle, grain stores and unharvested crops when they were taken to Wollega. Peter Niggli's (1986:5) deep interiews with Tigrayans who fled to the Sudan in 1986 indicate also the prevalence of similar incidents.

It was not only the mode of recruitment and loss of property which are grounds for dissatisfaction. Much resentment is also caused by the harsh conditions of transition. Respondents maintained that they were transported in crammed trucks and buses over long distances that often cover more than a thousand kilometers and take between three and five days to travel. As with the transportation to the labour camps at Humera, little attention was given to the physical comfort and well-being of the relocatees during the journey or afterwards. Some humanitarian organizations maintained that there were rather high rates of casualty because of the journey.

The most visible sociological effect of the resettlement operation is family disintegration. During the 1979-82 operations only men were relocated from Wollo and Tigray to the south. Most of these men being in the age range of 18-40 years were married and family heads. Although family reunification is carried out later on by the Relief and Rehabilitation Commission (RRC), our respondents did not hear from their families during the four years they stayed in the settlement camps in Asosa or after. Other studies and observations made inside the country (Sandstrom, 1986:99) 
and among refugees in the neighbouring countries (Niggli, 1986) indicate convincingly that social disintegration is one of the main consequences of the relocation process. Sandstrom notes that family disintegration is not only widespread but in several cases so profound that unaccompanied children have been separated from their parents.

In reality, the effects of resettlement have been the opposite of what was intended. Instead of mending the social fabric that was torn asunder by famine, it has exacerbated the disintegration of peasant society. Famine victims were separated from their communities by force, families were broken up and the suffering that was inflicted by the famine was worsened by the inconsiderate treatment during the movement to the south. Thus, instead of alleviating the agonies of a severely traumatized population relocation has brought about even further disruption and greater stress for the survivors of the catastrophe.

Life on the resettlement schemes became a continuation of the ordeal caused by famine and the movement. The social and psychological stress was further exacerbated by conditions at the places of resettlement, mainly because of the total lack of facilities on the arrival of the relocatees. In Asosa, the settlers were dropped in the "middle of nowhere" and were told to gather wood and grass and build their huts, stores and office buildings, and to clear bushes and prepare farm lands (see also Niggli, 1986). The initial reaction of the relocatees was one of shock. The hopes entertained by some particularly those whose migration was relatively voluntary, regarding a better standard of living were dashed. The camps so created were nothing like the villages from which they originated. This was exaggerated by the geographical contrasts between Asosa, which is located in a flat and hot lowland area, and the cool high plateau of Wollo and Tigray and the differences in the agricultural systems and food crops. The linguisticdistance between the Kushiticand Nilotic indigenous peoples and the Semitic settlers is also a cause for socio-cultural stress and social conflict.

In spite of the hard work necessitated by the pioneer nature of settlement life and the prevalence of malaria and other contageous diseases food rations are inadequate and medical facilities rudimentary. The death rates reported by respondents from the Asosa resettlement schemes are similar to those we have already mentioned in relation to the labour camps at Humera. Regarding the food conditions, Clay and Holcomb have reported that:

Even the largest rations reported were woefully inadequate for a population working 12 hours per day, six and half days per week. The food needs of some of the population in the camps were even higher than might normally have been expected because of their resettlement due to both withholding of food during the resettlement process and the hard labour required of them (1986:95).

The catalogue of complaints directed against the resettlement programme by relocatees is long and we will not dwell upon all of them here. In short, the major weaknesses of the operation are: the social and economic coercion used in relocation, the physiological, social and psychological stress caused by the sudden and massive movement, and the lack of material and infrastructural support at the resettlement sites. The result is bitterness and resentment since the relocatees feel abused, persecuted and diminished by both nature and man. This resentment is evidenced by the mass desertions from the resettlement schemes. 
Impacts of resettlement on the indigenous peoples

Resettlement affects the life of the indigenous people in several ways. The local people in the areas of resettlement have also shown resentment towards the programme. Their opposition to the programme has historical and material bases. From the historical perspective they relate resettlement to their experiences of conquest at the turn of the century. The resettlement projects raise in their minds the spectre of a second conquest and parallels are drawn between them and the ketemas mentioned in the previous chapter. The resettlement schemes are considered as the new keternas at least functionally and the settlers as the new naftanyas. The differences between the objective conditions that led to the conquest and colonization of the south during the last century and those that have motivated the relocation programme do not matter very much here because in both instances the indigenous peoples considered themselves to be the disadvantaged party. Together with the state farms, the settlement schemes have become the symbol of continuing alien control of land in the south and southwest.

Economically the resettlement programme constitutes an onerous burden upon the local population who have also been the victims of drought and famine. They are asked to feed the relocatees on their way to the resettlement schemes and in some places even for weeks afterwards. In Kaffa they were ordered to build houses for the settlers (SI, 1985:5) and some households have even been forced to sell their farm oxen in order to make contributions to the settlement programme (Sandstrom, 1986:140,142). In Wollega, one of the reactions of the local population to resettlement was mass flight and since 1979 more than 15,000 Berta and Oromo peasants have crossed into the Sudan particularly from the Asosa area.

\section{Ecological consequences of resettlement}

The negative consequences of the resettlement programme are not limited to political and economic spheres. It has also a serious impact on the ecology of the resettlement areas. This concerns mainly deforestation and soil erosion.

When the Ethiopian Empire was created at the turn of the century about 40 per cent of its land area was covered by dense forests. This was reduced to about 16 per cent by the middle of the 1960s. By 1982 only about 4 per cent of Ethiopia's land area was under forest (see Kuru, 1986). These statistics indicate very rapid deforestation. The alarming link to mass population relocation is that the resettlement schemes are located close to the few remaining forests in the country. Both in Bale and the southwest, resettlement schemes have been concentrated in areas with virgin forests. Thousands of trees have been cut down by settlers to build their houses, and thousands of hectares of forest land cleared for farming. According to refugees, some of the districts in these regions have been totally destroyed (Clay and Holcomb, 1986: 183-187).

Environmental scientists indicate that these forests have micro-zonal effects on rainfall since these regions have the highest rainfalls in the whole of the Horn of Africa. Because of the survival of the natural cover, soil erosion is lower than in other regions (Kuru, 1986:39). The importance of these forests is not limited to local ecological stability. The forests have a macroeffect on the economy of the whole area because coffee production, the mainstay of Ethiopia's economy is linked to their survival. Abundant rainfall and shade of tree's are essential conditions for the 
cultivation of the coffee plant. Even the production of food crops is dependent on the existence of the forests. The few surplus areas (e.g. the Arsi highlands) are located near the forested zones and the destruction of the remaining natural cover could have serious consequences for the country's precarious food supply.

There is ample evidence regarding the acceleration of deforestation and soil erosion in recent years in the resettlement areas. In order to make room for the resettlement projects and state farms tens of thousands of acres of virgin forests and bushes are already cleared in the Dhidheesa, Angar, Dabus and Baro River valleys.

The ecologicaleffects of resettlement in southwestern Ethiopia is apparent even in the Sudan. Sandra Steingraber (1987:63) notes that effects of accelerated deforestation and soil erosion in the Wollega region and particularly Asosa is already evident at the Rosieres dam on the Blue Nile across the border where hydrobiologists and engineers have noticed rising silt and increased logs carried down the stream. The same is even observed in the Yabus river which according to the report has carried down into the Sudan an unusual amount of logs and silt after the short rains of May 1987.

\section{Villagization and Displacement: A Critical Assessment}

Since they fled from Ethiopia before villagization was widely implemented none of our respondents mentioned it in connection with their uprooting. Villagization is currently, one of the major causes of dissatisfaction and displacement throughout Ethiopia, so it is relevant to make a brief critical assessment of the operation. This also makes the picture of the immediate subjective and objective causes of mass exodus from Ethiopia more complete. Our discussion and analysis of villagization is based on data gathered by other researchers, personal communication with individuals directly related to or affected by the programme and the author's knowledge of rural conditions in Ethiopia.

As we have indicated in the previous section, villagizationis the process of moving peasants who lived traditionally in scattered homesteads to "villages". The size of these villages varies from place to place. In Arsi, they consisted of about 150 to 400 houses. Some of the villages are bigger than nearby towns and accommodated thousands of inhabitants (Cohen and Isaksson, 1987:xv). In Wollega such villages could contain up to 1000 houses (Steingraber, 1987:2). Every report indicates that the villages are built along or near roads in a regimented pattern laid out by government planners in Addis Ababa.

\section{Implementation}

Available information indicates that coercion is invariably used in the implementation of villagization. However, the degree of violence used to move the peasants varies from place to place. One report listed physical abuses that were visited upon peasants in Hararghe (Vallely, 1986) to move them to the new villages. It indicated, inter alia, that those peasants who resisted villagization were shot or imprisoned and 
that their homes were set on fire. It pointed out that the peasants were order to move on short notice and that little or no preparation was made. Furthermore villagization disrupted agricultural activities as it was conducted in the middle of the harvesting or planting seasons..$^{15}$

Steingraber's (1987) study, which is based on information given by villagization refugees from the Wollega and Illubabor regions, describes several incidents where naked violence was used by authorities. Another study conducted for SIDA on villagization in the Arsi region suggested that psychological coercion rather than physical violence was used to implement the programme. Its authors, however, added that even there villagizationinvolved hardship (Cohen \& Isaksson, 1987:xv).

\section{Objectives: overt and covert}

Oficially villagization is concerned with six objectives. These are: 1 . to enhance extension services aimed at increasing agricultural productivity; 2 . to promote more rational land use patterns and conserve natural resources; 3 . to facilitate access of rural people to services; 4 . to strengthen security and self-defence; 5 . to promote collectivization of agriculture, and 6. to give the government the political control needed to ensure that rural society is reconstructed and agrarian socialism achieved (Cohen \& Isaksson, 1987: xii-xiii). The programme is also used by the authoritiesfor other purposes which may not be in the interest of the people. For example it is used to facilitate revenue collection and to speed up the Amharization process. The short life span of the programmes does not allow a conclusive assessment of its impact. However, it is possible to make some tentative remarks based on present trends in the villagized communities, the objective conditions in Ethiopia and the experience of other African societies that have implemented villagization on a large scale.

\section{Impact of villagization on basic services and living conditions}

The available information indicates the lack of basic services in the new villages and the deterioration of rural life because of villagization. Cohen and Isaksson point to the fact that the services most urgently needed, such as community pit latrines and water supply, were lacking in the villages they visited in Arsi. They underline the lack of realistic plans to achieve the service objectives of the programme within the foreseeable future. The government lacks funds, and the peasants under present circumstance definitely can not pay. What is more, government guidelines preclude private enterprise from setting up even small catering services.

The housing conditions of the peasantry deteriorated as they moved to the new villages. The huts which the farmers could build in the villages were smaller in size than their previous homes. The quality of construction was no better. Most of the huts were incompletely built due to loss of material in dismantling and transportation, and the speed of villagization. Cohen and Isaksson (1987:45) suggested that the living conditions in the new villages must have led to increased illness as the hastily reconstructed tukuls provide little protection from the cold plateau winds and driving tropical rains. The houses in the new villages lack fences, bins and pens. Consequently it is difficult to store agricultural products. Animals trespassing on other compounds has also become a constant problem leading to increasing conflicts between neighbours. 
The deterioration in living conditions is even more marked in the coffee-producing regions of the southwest. Here, farm houses were relatively better than in the rest of the country. In Kaffa, Illubabor and Wollega a large percentage of the peasants lived in rectangular houses built from eucalyptus poles, adobe and tin roofs. Some had cement floors. Even the traditional tukuls were much larger than in other regions. When these houses were dismantled in the process of villagization, the owners were able to construct only "very shoddy dwellings." Since dismantling and moving materials was relatively difficult and time-consuming, villagers built their shelters often from sticks and grass collected around the new sites (Steingraber, 1987:21).

That housing conditions in the villages will improve in the coming one or two decades seems unlikely. Regarding Arsi, the SIDA report concluded that neither the farmers nor the government will have the funds to carry out house improvements in either the mid- or the long-term. This results from government policies which have led to a stagnant economy and low revenues (Cohen \& Isaksson, 1987:45).

The scattered pattern of human settlement in Ethiopia is part of an adaptation mechanism. The mode of subsistence production necessitated this pattern of settlement. The population is distributed more or less evenly according to the availability of resources such as water for human and livestock consumption, pasture, fuel and the suitability of the soil for crop cultivation. The peasants lived near to their fields, within easy reach of pastures and water sources. The scattered pattern of settlement aids in the control of epidemic diseases. The distances between the homesteads makes possible the effective quarantine of those who contract diseases like typhus, cholera and small-pox.

Villagization has seriously disturbed this balance. And the services and means to tackle the problems which can arise because of this disturbance are not provided in the new villages. Hence, the human concentration together with the lack of clinics, water shortages, lack of pit latrines and general sanitation, poses serious health hazards in the new villages. According to one informant infections which used to affect only a few individuals are now developing into epidemics in some of the villages in Wollega. Fires seem also to have become common ${ }^{16}$.

The viability of villagization as a means to economic development and the betterment of the quality of life in the rural areas is also seriously questioned. Experience from elsewhere in Africa shows the failure of villagization to achieve its objectives. The Tanzanian ujamaa villages are a case in point. Like the current villagization in Ethiopia, inadequate planning and poor implementation characterized the ujamaa programme. State and peasant interests differed, so that various mechanisms had to be used to enforce peasant subordination to the interests of the state". The result was stagnation, not development. Agrarian socialism remained an illusion because the peasants resisted, agricultural production declined and the economy became bankrupt.

Villagization has deleterious effects on economic production and social welfare for two main reasons. The long walking distances to the fields impinge on productive work time, and give for wild animals more opportunity to destroy crops. Secondly, the peasantry in most of the southern provinces particularly the Oromo and Sidama areas are dependent on a variety of perennial crops such as coffee and enset (ensete edulis) which are grown around the hamlets which dot the countryside. Most of these crops can grow only in soils that have been fertilized for decades by household refuse and dung. 
Relocation may also mean the destruction of these crops because, once the households are moved, constant tending may become impossible.

This means the loss of a substantial source of income for peasant households, because these crops are their main cash earners. Coffee, about 95 per cent of which is grown on small peasant holdings, is one of the crops which will be affected. The consequences of villagization may also be adverse for the national economy. Coffee accounts for more than half of Ethiopia's export earnings.

Couched in terms and phrases that promise progress and welfare, villagization appears to be a radical policy that could solve the problems of the peasantry in Ethiopia. In reality it is exacerbating their burdens. It was conceived and implemented from above. The primary concern of the policy is the interest of the state and the peasants are used to achieve goals in line with this interest. Government control has clearly increased in the villagized areas. The delivery of surplus grain to the parastatal AMC is ensured. More room for state farms and resettlement is created. Amharization, an intrinsic objective of the villagization programme, is enormously enhanced ${ }^{18}$.

The peasants have reacted to the programme in various ways. In some areas were the liberation fronts are active, peasant reaction has not been passive. There are reports that many have already fled across international borders (Vallely, 1986, Steingraber, 1987).

\section{Types of Respondents and Forms of Displacement}

The features of the mass exodus from Ethiopia display a certain degree of complexity. Those who form the stream a broad spectrum of the peoples and cultures of the Ethiopian region.

The motivations for leaving were also varied. In most cases the causes of flight were compounded by an interplay of political, economic and natural factors. When we apply the conceptual typology suggested in Chapter 4 to the sample, the following main categories of refugees emerge:

1. Political activists aiming for radical change in Ethiopia.

2. Members of the former regime and the feudal order aiming at restoring their former positions and privileges.

3. Displaced masses.

4. Opponents or victims of government socio-political and economic policies.

5. Those who are 'carried along by the stream'.

The persons belonging to the first category were mainly connected to the various national liberation fronts such as the OLF, TPLF, ELF and EPLF, which have representations (although often unofficial) in the Sudan. They include also former members of the EPRP and MEISON, two organizations which were at the centre of the urban political conflicts of 1974-77. This category of refugees was quite small in size, accounting for less than 10 per cent of the sample. Originating from the urban areas, they include members of the educated élite and other sections of the burgeoning middle class.

The motivations and patterns of their flight do not always fit exactly the general picture suggested in Chapter 4 regarding this category of exiles. The departure of 
most of the respondents was not planned or organized as suggested. Some of them were persecuted prior to their departure and their flight was acute.

In general, this category of exiles came from the most politicized section of the population. Most were the products of the Ethiopian student movement of the late sixties and the early seventies, and belonged to the intellectual cream of society. The refugees in this category were return oriented and were actively working for it. Although the majority of them fled in reaction to a threat to their lives, they saw a purpose in their exile and anticipated a victorious return to their country of origin. Since these refugees were characterized by differing views and divergent goals regarding the future of Ethiopia, their strategies and the conditions they set for their return varied accordingly. Those who identified with the liberation movements, particularly the ELF, EPLF and the OLF, often gave the independence of their territories as a precondition to repatriation. Others, including those who sympathized with the TPLF, said they would not consider returning home until there was a change of government.

The refugees in the above category were generally socialist in their ideology. The liberation fronts to which some of them belong even practise socialism in their political activities inside and outside Ethiopia. As a whole they had a strong influence over the refugee communities. Those belonging to the liberation fronts were often considered by their countrymen as de facto leaders and representatives.

The second category of refugees in the sample consists of members of the former feudo-bourgeois order and those which support the EDU. If not the direct restoration of the old socio-political order, the aim of this group is at least to establish a similar political system. Compared with the first category of respondents who were socially committed and egalitarian, the members of this group were more preoccupied with the re-conquest of power and the restoration of prestige and privileges which they had lost to the revolution. The group was small and commands little influence over the refugee community covered in this study.

The third category of refugees in the sample represents the displaced masses whose flight was in reaction to events over which they had little or no influence. They were mainly victims of armed conflict between government forces and the liberation fronts. As such they were not direct targets of aggression. However, as noted, the military regime has at times deliberately repressed civilians in order to destroy opposition support in the countryside, thereby spreading panic and causing mass displacement.

In mass flight situations there are often those who join the stream for economic reasons and who are referred to as 'economic refugees'. In our sample the percentage of respondents who gave poverty as one of the reasons for their migration was small. However, the number of famine-affected migrants has dramatically increased since our fieldwork and the Sudan has become their major host.

The cause of famine is often blamed solely upon the vagaries of nature. This view is wrong because it conceals the social and political causes. Centuries of feudal exploitation in the north and the gabbar system in the south have reduced the peasantry to a level which makes them very vulnerable to famine with the slightest crisis in food production. However, although drought and famine recur in the history of Ethiopia, mass migration across international borders is a new development and clearly indicates the progressive deterioration of socio-economic conditions over the last decade. 
Whether they were victims of armed conflict or natural calamity, respondents in the 'displaced masses' category came mainly from peasant backgrounds and constituted more than 50 per cent of the study sample. But there was also a minority of displaced wage labourers from pre-revolution commercial farms. The flight of displaced masses occurred in waves and their settlements were concentrated in a few localities in the border areas these refugees were the most eager to repatriate, especially those who fled from famine. However the majority, those who fled due to armed conflict were not prepared to return until peace was restored.

The fourth category of respondents represents a relatively large group of refugees who left Ethiopia in defiance of the military, social and economic policies of the government - in particular, conscription, forced labour and involuntary relocation. Even though there were elements of conservative resistance to change in their attitudes towards the government-policies, the overriding cause of flight was the way in which the policies were implemented. In other words, it was the inability to cope with the hardship and the social disruption resulting from the changes that weighed most in making the decision to flee. Unlike the respondents in the first two categories, refugees in this group were politically uncommitted. However, once in exile they tended to be attracted to the politics of the opposition.

Such refugees often flee in small groups, but occasionally their displacement takes mass proportions, particularly when in response to relocation. Although the majority were peasants fleeing from forced relocation within Ethiopia, this group also included petty bourgeois and lumpen elements who had escaped from labour camps or deserted from military service. The repatriation of this kind of refugees is perhaps the most complicated. Unlike those displaced by armed conflict and natural disaster, they were uprooted from their original environments by a deliberate state policy.

The last group of refugees in our sample consists of individuals who were carried along by the stream. These were people who fled not because of a threat to their physical security or as a protest against injustice, but in response to a mass flight psychosis. Some left because their peers or members of their reference groups had done so. Others left because of a feeling of asphyxia created by the polictical system. The numerous checks and controls push some individuals to take to flight though many not be threatened or particularly opposed to the government.

There is also a sub-group within this category of refugees who take advantage of the situation created by the mass movement to fulfil frustrated aspirations for further education and economic betterment. In exile the conditions of these refugees were no better than other from similar backgrounds. They faced the same survival problems and their future was equally uncertain. 


\section{Chapter 6 \\ Flight Dynamics and \\ Intervening Obstacles}

\section{Introduction}

In two of the previous chapters we discussed and analyzed the historical background and the current situational variables which generate refugee flows from Ethiopia. The focus of this chapter is the process of flight or "transition" itself. We will attempt to delineate those variables which in addition to changes in the socio-political environment may influence the individual's or group's decision to flee. We will also describe some of the problems that were encountered during flight and on arrival in the host country.

\section{The Decision to Flee}

As has been stated in Chapter 5, the main "causes" of flight are changes in the socio-political environment which are felt to be detrimental to individual or group security. Such factors are frequently persecution on ideologicalor racial grounds and armed conflict. Nevertheless, it is also a well known fact that political and religious persecution, war and the denial of basic rights do not always result in refugee exoduses. And even when social conflicts and political and religious oppression do generate exiles, not everyone chooses to leave.

The question is then: why do some people flee while others who are in similar situations choose to stay? Are there other factors beside the threat to physical security which determine the movement of refugees? Some writers have suggested psychological, social structural and cultural factors as the major explanatory variables for these differences of response to threatening situations. We will examine the case of our respondents using this conceptual framework.

\section{The decision making process}

The process of decision making, the time taken and the factors taken into account, vary between voluntary migration and refugee movements. Voluntary migrants make the decision to move after a long period of consideration and consultation, and after the advantages and disadvantages of migration are objectively assessed. This assessment is based on information about the country of immigration. When a decision to flee is made these aspects are often absent.

Kunz has argued that the absence of positive motivation to settle elsewhere and 
Table 6.1 a Distribution of respondents by information (\%)

\begin{tabular}{lc}
\hline Information & Per cent \\
\hline Had information before flight & 30.3 \\
Had not information & 69.7 \\
\hline Total \% & 100.0 \\
$\mathrm{~N}$ & 413 \\
\hline
\end{tabular}

Table 6.1b Distribution of respondents by flight plan (\%)

\begin{tabular}{lc}
\hline Flight plan & Per cent \\
\hline Planned flight & 31.7 \\
Spontaneous flight & 68,0 \\
No answer & 0,2 \\
\hline Total \% & 99.9 \\
\multicolumn{1}{c}{$\mathrm{N}$} & 413 \\
\hline
\end{tabular}

the reluctance to uproot (Kunz, 1973:130) is the underlying characteristic of the refugee decision making process. Therefore, adds Kunz:

an inner self propelling force . . . is singularly absent from the movement of refugees. Their progress more often than not resembles the movement of the billiard ball: devoid of inner direction their path is governed by the kinetic factors of inertia, friction and vectors of outside forces applied to them (p. 131, footnote).

Kunz's conceptualization of refugee movement as kinetic is criticized by Hansen who argued that such an interpretation tends to deny the importance of decision-making on the part of those who flee and instead suggests blind flight:

I believe on the contrary, that both refugees and regular migrantsmake their moves because of decisions that compare alternatives, even though the refugee is originally opposed to moving and is repelled or pushed by the negative or threatening changes in his or her place of origin rather than attracted by the inherent positive aspects of the destination (Hansen, 1982:32).

According to our findings most of those respondents, at least those who came to the Sudan before March 1983, did not have the chance to assess the cost of flight or as Hansen (1982:31) put it to "choose their destination with more deliberation". Even if their movement was not wholly "kinetic" and even if they had a certain degree of control or power over their actions it was only a minority who made preparations and plans for their flight or deliberately chose their destination.

Different alternatives can be compared only when the refugee or immigrant has information about conditions in the country of immigration. But, as is shown in Table 6.1a, only about 30 per cent of the respondents had information about the country to which they fled. Nearly 70 per cent did not have any information regarding their destination or even the route they had to follow at the beginning of the flight. This lack of knowledge about conditions in the Sudan on the part of such a large proportion of respondents indicates the absence of "pull" factors that could 
have influenced their decision to leave. This invalidates the argument that it is the availabity of aid on the other side of the border that determines the movement of refugees in the Horn of Africa.

Only 32 per cent of the respondents said they had prepared for their flight ahead of time (Table 6.1b). Preparations included selling property, studying the flight route beforehand, contacting guides and, in the case of a minority of the urban respondents, acquiring papers (legal or forged) to be used to reach their destinations. This group consisted mainly of those who were able to anticipate danger. However the major current in refugee movements consists often of those who are in acute danger. Thus the majority of our respondents were unable to make any preparations whatsoever since they left in a rather panicky manner, pressed by acute threats to themselves or their families. The push force was overwhelming and the kinetic factor dominant in their movements.

\section{Personality and flight}

Personality is a key element of migratory behaviour. Taylor (1969) identifies a number of characteristics which distinguish migrants and non-migrants. He suggested that migrants and non-migrants differ not only in their perceptions of adverse conditions but also in their reaction to them. He characterized migrants as having quicker reactions and as a category possessing qualities which differentiated them from non-migrants. These qualities, according to Taylor (1969:116), are the "sense of dislocation" as compared to non-migrant's "sense of belonging" and "aspiration" compared to non-migrants "satisfaction" with their conditions.

Similar concepts are also employed to explain refugee movements (Prins, 1955; Boesch, 1982). Prins suggests that the decision to flee is the function of "inner causes". Those who flee are driven by an "unconscious desire" or "ego strength" whereas those who stay behind apparently lack the personality traits needed to undergo the severe emotional trauma which flight from one's own country involves. Elaborating on Prins's propositions Boesch (1982:59) argues that those who flee have the strength to act, have confidence in their action potential and belief in their ability to master coming situations. Those who do not flee, on the other hand, are those who lack self-confidence to try the unknown. For both Prins and Boesch the presence of an "outer" threat in the form of political, religious or racial persecution, war, etc., provides those who flee with a unique 'opportunity' to realize hidden aspirations. What is more,

... a threat activitates not only fears, but latent aspirations, which converging into anticipation of a future, will impact back upon the experienced present (Boesch, 1982:59).

The personality approach assumes that the individual is the decision-making unit. However, in most flight situations, particularly in rural Africa, it is the group which makes the decision to move or stay when faced by outer threat. This collective responsibility minimizes the role of the individual personality in the decision-making process. For example, our respondents from Yabus and Muguf told us that before they left home, a collective decision was made by the elders of their village regarding their flight to the Sudan and that everybody in the community had to follow the decision. It seems from our observations that decisions are often reached in a similar manner in mass flight situations, which make up the major proportion of refugee 
streams from Ethiopia. Here it is group pressure and "mob behaviour" which influences decisions rather than personal characteristics or the coincidence of subjective motives and objective causes.

However, this does not mean that personality can totally be discarded as an explanatory variable in the flight decision-making process. Our findingsindicate that when decisions are made individually, as is the case with more than two-thirds of our respondents from the urban areas, it is not everybody that is threatened who leaves. Even members of one and the same family may not make similar decisions under threatening circumstances. For example, about 40 per cent of our respondents left behind members of their families in the country of origin. At least one-third of these were also exposed to the same danger which they themselves fled from. Some of these were unable to flee because they were too old, sick or weak to undertake the arduous journey. But there were also those who were physically fit but who, in spite of the threat to their lives and the opportunity of escape, were reluctant to flee.

From the limited information which we were able to gather from our respondents, such people could be broadly categorized as optimists, fatalists and altruists. The optimists tend to believe that danger will disappear and everything will soon be as before. Their opposites, the fatalists, tend to hold the view that since everything is predetermined there is no sense in trying to avoid danger by fleeing from one's home. They fear that one will be caught and punished by the authorities while trying to flee. This is a well-founded fear since attempting to leave Ethiopia without official permission is categorized as crime (Addis Zemen, April 20, 1982) punishable by lengthy imprisonment or even death. The altruists are those who are unwilling to leave behind weak family members, relatives and others in order to save their own lives. These are people who do not distinguish their own safety from that of the group.

Although the personalities of those who stay at home inspite of danger and possibilities for flight could be construed in terms outlined above it is not right to make any conclusion based on our data since the information did not come from the people concerned. The optimism, fatalism and altruism which our respondents saw in those who stayed at home may conceal the true motives for staying such as fear of the unknown, reluctance to uproot and so on.

\section{Peasants and pastoralists}

Kibreab (1985:ii, 93) maintains that "the propensity of people to respond to a situation which they perceive to be dangerous by resorting to flight is higher among pastoral communities than among communities with a long history of being sedentary". He bases his conclusion on a study conducted among highland peasant and low-land agro-pastoralist refugee communities originating from Eritrea and living in eastern Sudan. This may be true for Eritrean refugees but we should be cautious not to generalize this as a fact of population movements. The author's own observations while working among pastoralists and peasants in different parts of Ethiopia indicates a strong reluctance among pastoral and agro-pastoral communities to "uproot" from their home areas. The pastoralist's transhurnant mode of existence is an adaptive mechanism and should not be construed as a sign of "rootlessness" or lack of attachment to a specific place. It would also be an overstatement to posit that the attachment of peasants to their plots of land as a source of status and kinshipidentity 
binds them as a category to their villages "even at the cost of their lives" (Kibreab, 1985:90). Peasants constitute the major currents of internal (rural to urban) and international population movements in the Third World. Peasants are not exclusively reluctant to leave their traditional homes and neither are pastoralists particularly inclined to give up easily and flee when confronted with threatening situations. This can be illustrated by examples drawn from the reactions of peasants and pastoralists in Wollo to the consequences of famine in 1973-74, and the responses of pastoralists in the Ogaden to the attempt of the Ethiopian government to settle them elsewhere in the province. When a severe drought hit northern Ethiopia in 1973-74 the peasants of Wollo left their villages and moved to other areas in search of subsistence. The pastoralists of the Afar lowlands, in spite of the total loss of their herds and even worse famine, chose to stay in their home areas. Consequently, many of them perished.

Another instance which indicates the reluctance of pastoralists to uproot is the resistance shown by the Somalis of the Ogaden when the Ethiopian Relief and Rehabilitation Commission (RRC) attempted to move about 100,000 drought victims and settle them along the Wabe Shabelle River away from their traditional grazing areas'. In spite of material incentives, less than 10 per cent were ready to take the "opportunity". The rest, in defiance of RRC's attempts to relocate them, left the relief camps and dispersed, risking the consequences of losing all access to relief supplies. These examples demonstrate how strong the attachment of pastoralists can be to a territory which they consider to be their home.

If there is an over-representation of pastoralists among the refugee population in the Horn of Africa, which we doubt in the case of the Sudan, it can be better explained by variables other than socio-cultural values and attachment to land in the community of origin. These factors do influence decisionsto flee but they may not be the main reasons.

The vulnerable position ofpastoralists. Pastoralists and agro-pastoralists have always borne a large share of the consequences of conflict in the Horn of Africa. Looked at in an historical perspective, it was these groups who were most affected by the partition of the Horn of Africa between colonial powers at the turn of the century. The Afar were divided between Abyssinia (Ethiopia), Italy and the France. The Somali were partitioned by the Italians, French, British and Abyssinians, the Oromo in the south by the British and Abyssinians; and the Beni Amir between Italy and the Anglo-Egyptian Sudan.

The fragmentation of the pastoralist-inhabited lowlands had far-reaching consequences. Most of all it led to the perpetuation of conflict in the area. The pastoralists reacted with varying intensity to the fragmentation of their lands and the alien rule imposed upon them. In Ethiopia, the animosity between highlanders and lowlanders was intensified. The little relation that existed between the Ethiopian state and the pastoralists has always been characterized by conflict. No development was brought to these areas and tax collection took the form of official raids and ambushes. The pastoralists and agro-pastoralists as cultural minorities occupy peripheral social and economic positions and have no share in political power. The policies of national integration engineered by the Christian controlled state pay no regard to the Muslim pastoralist way of life. In fact, they often are aimed at its destruction (Markakis, 1984:554-555). 
Table 6.2 Duration of flight by sample site (\%)

\begin{tabular}{|c|c|c|c|c|c|c|c|}
\hline $\begin{array}{l}\text { No. of } \\
\text { days }\end{array}$ & Gedaref & Tawawa & $\begin{array}{l}\text { Um } \\
\text { Gulịa }\end{array}$ & $\begin{array}{l}\text { Um } \\
\text { Rakoba }\end{array}$ & $\begin{array}{l}\text { Damazin } \\
\text { Kurmuk }\end{array}$ & $\begin{array}{l}\text { Yabus } \\
\text { Muguf }\end{array}$ & Total \\
\hline $\begin{array}{c}1-7 \\
8-14 \\
15-21 \\
22-\end{array}$ & $\begin{array}{r}76.8 \\
5.8 \\
5.8 \\
11.5\end{array}$ & $\begin{array}{r}84.0 \\
6.2 \\
3.6 \\
6.2\end{array}$ & $\begin{array}{r}91.7 \\
4.1 \\
1.0 \\
3.1\end{array}$ & $\begin{array}{r}88.6 \\
7.1 \\
4.3 \\
0.0\end{array}$ & $\begin{array}{r}93.7 \\
3.1 \\
0.0 \\
3.1\end{array}$ & $\begin{array}{r}100.0 \\
0.0 \\
0.0 \\
0.0\end{array}$ & $\begin{array}{r}87.4 \\
5.1 \\
2.9 \\
4.6\end{array}$ \\
\hline $\begin{array}{l}\text { Total } \\
\mathrm{N}\end{array}$ & $\begin{array}{c}99.9 \\
69\end{array}$ & $\begin{array}{c}100.0 \\
113\end{array}$ & $\begin{array}{c}99.9 \\
97\end{array}$ & $\begin{array}{c}100.0 \\
70\end{array}$ & $\begin{array}{c}99.9 \\
32\end{array}$ & $\begin{array}{c}100.0 \\
32\end{array}$ & $\begin{array}{c}100.0 \\
413\end{array}$ \\
\hline
\end{tabular}

Many wars have been fought in the territories of the pastoralists over the last twenty-five years because of these and other differences. Even today much of the armed conflict between the military regime and the nationalist movements are concentrated in the lowlands. Armed struggle for the liberation of Eritrea started in the lowlands in the 1960s and is still most intensive there. These armed hostilities have affected the pastoral and agro-pastoral societies most seriously. The Ethiopian armed forces have always treated the pastoral and agro-pastoral communities very brutally, and the growing militarization of the administration has exacerbated the situation over the past ten years. It is this, together with the proximity of the lowlands to international borders, which more than any other factor accounts for the overrepresentation of pastoralists and agro-pastoralists among refugees in the Horn of Africa. $^{2}$

\section{Accessibility to international borders}

Distance from the border areas also determines the rate of refugee flow from a given area. Revenstein (cited in Lee, 1969) has proposed that the volume of migration is inversely proportional to the distance between the points of origin and destination. Lee (1969:290) has added the concept of "intervening obstacles" which includes distance, costs of migration, institutional hindrances and so on.

In the cases of the refugee exoduses the occurrence of intervening obstacles in the form of hardships, illness and the danger of being detected by the security force increases with geographical distance. The relationship between distance and volume of migration is reflected in the pattern of movement and settlement of the majority of African refugees. Various research reports indicate that most African refugees flee only short distances as they both originate from, and settle in, border areas (Gould, 1974:422; Rogge, 1981:196). The same pattern is evident in the movement and settlement of refugees from Ethiopia to the Sudan. As is shown in Table 6.2, the great majority -87.4 per cent - of our respondents travelled only 1-7 days (in fact, about 90 per cent of these travelled only 1 to 3 days) to reach the border. However, our data do not tell us the exact distance covered. Almost 80 percent (Table 6.3) of the respondents walked all the way to Sudan, and the speed at which they travelled was affected by such factors as the weather, the terrain and the number of stops made to avoid detection.

Hence, the majority of the respondents moved only a short distance and came from places in the range of $100-200 \mathrm{~km}$ from the border areas. They were at least near 
Table 6.3 Flight days by type of refugee

\begin{tabular}{lcc}
\hline Flight days & Urban & Rural \\
\hline $1-7$ days & 83.2 & 92.0 \\
$8-14 "$, & 5.6 & 4.5 \\
$15+\quad 11.2$ & 3.5 \\
\hline Total \% & 100.0 & 100.0 \\
$\mathrm{~N}$ & 214 & 199 \\
\hline
\end{tabular}

$\mathbf{X}^{2}=11.07,2$ d.f., $\mathrm{p}<.01$

the border areas when they made the decision to flee. What is important to note here is that it is not only border areas which were affected by social conflicts and natural calamities. Some central regions like Wollo were equally affected but produced very few external refugees due to the distance between these regions and the international borders.

Lee (1969:295) proposes that as distance of migration increases the migrants become an increasingly superior group. By this Lee meant that distance and the intervening obstacles tend to weed out the weak and the incapable. In our findings the distance travelled by respondents was related not only to physical attributes ( 85 per cent of respondents were between 17 and 40 years) but also to some structural characteristics of the communities of origin. For example, urban refugees tended to risk longer journeys than rural refugees, and persons with more education tended to travel longer distances than those with less education.

As shown in Table 6.3, 16.8 per cent of the respondents with urban backgrounds travelled more than 7 days to reach the border whereas the corresponding figure for rural refugees was 8 per cent. This difference becomes more significant if we take into account the fact that urban refugees tended to use faster means of transport to come to the Sudan. As can be seen in Table 6.4, 71 per cent of the urban refugees came to Sudan on foot, 26.6 per cent by vehicles and 2.3 per cent by animal transport. Among the rural refugees 83.4 per cent came on foot, 16 per cent by vehicle, foot and/or animal. This means that on average the urban respondents covered longer distances than their rural counterparts during flight.

Urban refugees flee not only longer distances before reaching the country of asylum but tend to continue their journey further into the host country. From the major urban centres, they gradually spread to other parts of the world. In comparison, rural

Table 6.4 Means of transport by type of refugee

\begin{tabular}{lcc}
\hline Means of transport & Urban & Rural \\
\hline On foot & 71.0 & 83.4 \\
Vehicle & 20.1 & 11.6 \\
Vehicle + foot/animal & 6.5 & 4.5 \\
Animal & $\mathbf{2 . 3}$ & 0.5 \\
\hline Total \% & 99.9 & 100.0 \\
$\mathrm{~N}$ & 214 & 199 \\
\hline
\end{tabular}

$\mathrm{X}^{2}=10.38,3$ d.f., $\mathrm{p}<.02$ 


\begin{tabular}{lccll}
\hline & $\begin{array}{l}\text { Border } \\
\text { areas }\end{array}$ & $\begin{array}{l}\text { Rural } \\
\text { towns }\end{array}$ & $\begin{array}{l}\text { Medium-sized } \\
\text { urban centre }\end{array}$ & $\begin{array}{l}\text { Capital } \\
\text { city }\end{array}$ \\
\hline University & 0.0 & 0.0 & $15.9^{*}$ & 13.2 \\
Secondary school & 0.0 & 33.0 & 13.0 & 38.0 \\
Primary school & 15.6 & 25.0 & 24.6 & 28.6 \\
No school & 84.4 & 42.0 & 46.4 & 20.0 \\
\hline Total \% & 100.0 & 100.0 & 99.9 & 99.8 \\
\multicolumn{1}{c}{$\mathrm{N}$} & 32 & 32 & 69 & n.a. \\
\hline
\end{tabular}

Source: 1 . Border areas (Yabus and Muguf), rural towns (Damazin and Kurmuk) and medium urban centre (Gedaref) survey questionnaire. 2. Capital city (Khartoum), "Eritrean and Ethiopian Refugees in Kartoum", Department of Sociology and Social Anthropology, University of Khartoum, 1979.

* The percentage of respondents with university education is quite high to be representative for medium-size-urban centres. It perhaps depends upon the concentration of educated refugees in Dem el Nur, the section of Gedaref included in this study.

refugees tend to move "only far enough to escape detection" or the jurisdiction of the home authorities. Once they cross into the host country they tend to settle at the first point of safety in the border areas. This is a general trend all over Africa and, the majority of African refugees being of rural origin, it has resulted in large concentrations of refugees in comparatively inaccessible and poorly developed border regions all over the continent.

Ethnic and kinship ties are often proposed (Gould, 1974; Hansen, 1982; Aall, 1967 ) as the main explanatory variables for the concentration of African refugees in the border areas. However, ethnic and linguistic regions do not always straddle international boundaries and every refugee group which stays in the border areas does not "settle among its kin" or is "welcomed, fed and cared for as part of the traditional hospitality". In the case of the Oromo refugees in the Blue Nile province and the Tigrayan and Amhara refugees in the Kassala province of the Sudan, their choice of the border areas is determined by factors other than ethnic ties with the local population.

The elders of the self-settling refugees in the Yabus and Muguf areas, for example, told us that they were reluctant to move further inland to government run settlement schemes because they wanted to be near their homes. According to them, one of the advantages of living near the border was the possibility of getting information now and then about their country of origin. Besides, as one of them put it, "home feels near when I look at the landscape on the other side of the border". Staying near the border keeps the hope of return alive, whereas moving further inland increases the distance between home and self. It also increases the likehood of change, which they want to avoid.

It is not only this emotional attachment to homeland and fear of the unknown which limits the movement of rural refugees to the border areas. There are also other obstacles such as lack of skills and language difficulties. Furthermore, in the urban area there are few chances for education or resettlement in other countries. Such chances, when available, are given almost exclusively to urban refugees. Thus the 
flight of rural African refugees is a single-step movement connecting the points of origin and destination, whereas the flight of most urban refugees consists of multiple steps.

Even among the urban refugees further migration tends to be highly selective. Refugees with higher education and occupational skills tend to drift towards the main urban centres and those with lower education tend to stay in the border towns. Thus, as indicated in Table 6.5, the percentage of well-educated refugees rises with increasing distance from the border areas. Hence, the educational background of respondents in the rather remote town of Damazin was somewhat lower than those from Gedaref, a busy commercial and agricultural centre. The level of education and the literacy rate of respondents was highest in the capital, Khartoum.

For most educated and skilled refugees, major urban centres like Khartoum are not their final destination. One study indicated that about 80 per cent of these refugees had no intention of staying in the Sudan. About one third had plans to immigrate to countries in the Middle East, about one quarter of them to Europe and the rest to the United States and other parts of the world (El Dawi, 1978).

\section{Implications of the findings}

This discussion of the differences in their flight patterns and preferences of urban and rural refugees would be trite if not for their implications. Given Africa's rapid rate of urbanization there will be more refugees with urban backgrounds in the future. It is thus likely that the number of refugees seeking asylum outside Africa will increase. The African refugee problem will not remain basically a regional responsibility, as it is today, but will become of global concern. Finding lasting solutions to the problem will also become increasingly difficult. Refugees will not be easily persuaded to "voluntarily" repatriate. They will be less docile, and will struggle more actively for their causes and rights. It is because of this possible development apart from moral, ideological and humanitarian considerations, that it is imperative that an international effort be made to attack the root causes of the refugee problem.

\section{Intervening Problems and Hardships}

Most refugees do not leave their home with a national passport in hand. Nor do they have pre-paid tickets for their transport since they do not take the national airlines or railways when they leave their countries. They leave in acute situations and for many of them their journey is hampered by acute problems. They flee in disguise, avoid the main roads; and are ignorant of what lies ahead since they travel through unknown territory often without guide. This makes flight for many a grope for safety in total darkness. And such flight is filled with numerous hardships and danger.

It was not my intention to tell my experience to those who have not gone through one like it. Some people may be interested to hear the story out of curiosity like you are doing now but I doubt that they could sense what it was like. Nonetheless, since you have asked for it I will tell it to you and it is up to you to believe it or not.

The above statement came from an interview with a middle-aged man who travelled 
Table 6.6 Major problems encountered during flight

\begin{tabular}{lc}
\hline Tyye of yroblem & Per cent \\
\hline Armed attack & 8.0 \\
Robbery & 3.9 \\
Other (rape, wild animals, etc) & 2.1 \\
No problem & 86.0 \\
\hline Total & 100.0 \\
$\mathrm{~N}$ & 413 \\
\hline
\end{tabular}

23 days on foot to reach the Sudanese border at Gissen. The statement may sound exaggerated but the story he and other respondents told us indicates the immense physical and psychological pressure which some refugees had to stand during their flight.

The most serious danger to people in flight is posed by human beings rather than by natural phenomena. ${ }^{3}$ As is shown in Table 6.6, about 14 per cent of our respondents suffered armed attack, robbery, rape and other types of violence on the journey to the Sudan. Armed attacks are carried out by border guards, the police, the local militia or regular army units. Sometimes refugees join smuggler-caravansor employ smugglers as guides and come under the fire of the police. Armed robbery of refugees is committed along almost all the routes used by our respondents to flee to the Sudan.

In addition to physical assault and robbery, about 50 per cent of the respondents encountered hardships caused by lack of food and water, malaria and other diseases, pregnancy and child birth during their flight. As is indicated in Table 6.7, lack of food and water were the two major problems and were experienced by about 40 per cent of the respondents.

Infectious diseases (mainly malaria) are serious problem all along the border areas

Table 6.7 Types of hardship encountered by respondents during flight by settlement site $(\%)$

\begin{tabular}{|c|c|c|c|c|c|c|c|}
\hline \multirow[b]{2}{*}{$\begin{array}{l}\text { Problems } \\
\text { encountered* }\end{array}$} & \multicolumn{6}{|c|}{ Settlement Site } & \multirow[b]{2}{*}{ Total } \\
\hline & Gedaref & Tawawa & $\begin{array}{l}\text { Um } \\
\text { Gulja }\end{array}$ & $\begin{array}{l}\text { Um } \\
\text { Rakoba }\end{array}$ & $\begin{array}{l}\text { Damazin } \\
\text { Kurmuk }\end{array}$ & $\begin{array}{l}\text { Yabus } \\
\text { Muguf }\end{array}$ & \\
\hline 1. Lack of food & 29.0 & 33.6 & 33.0 & 47.1 & 78.1 & 65.6 & 40.9 \\
\hline 2. Lack of water & 29.0 & 38.0 & 34.0 & 48.6 & 81.3 & 62.5 & 42.6 \\
\hline 3. Illness & 27.5 & 15.0 & 11.3 & 15.7 & 3.1 & 31.3 & 12.1 \\
\hline $\begin{array}{l}\text { 4. Child bearing } \\
\text { (Pregnancy, child } \\
\text { birth) }\end{array}$ & 0.0 & 1.8 & 3.1 & 2.9 & 0.0 & 6.3 & 2.0 \\
\hline $\begin{array}{l}\text { 5. No problem } \\
\text { encountered }\end{array}$ & 56.5 & 57.5 & 60.8 & 47.1 & 15.6 & 15.6 & 49.9 \\
\hline $\mathrm{N}$ & 69 & 113 & 97 & 70 & 32 & 32 & 413 \\
\hline
\end{tabular}

${ }^{*}$ Multiple responses (1-4). 


\begin{tabular}{|c|c|c|c|c|c|c|c|}
\hline \multirow[b]{2}{*}{$\begin{array}{l}\text { Problems } \\
\text { encountered* }\end{array}$} & \multicolumn{6}{|c|}{ Sample site (settlement) } & \multirow[b]{2}{*}{ Total } \\
\hline & Gedaref & Tawawa & $\begin{array}{l}\text { Um } \\
\text { Gulja }\end{array}$ & $\begin{array}{l}\text { Um } \\
\text { Rakoba }\end{array}$ & $\begin{array}{l}\text { Damazin } \\
\text { Kurmuk }\end{array}$ & $\begin{array}{l}\text { Yabus } \\
\text { Muguf }\end{array}$ & \\
\hline 1. Subsistence & 72.5 & 68.0 & 78.6 & 78.6 & 87.5 & 96.9 & 76.6 \\
\hline 2. Shelter & 78.3 & 65.5 & 80.4 & 78.6 & 81.3 & 75.0 & 75.3 \\
\hline 3. Culture/language & 62.3 & 76.1 & 36.0 & 34.0 & 75.0 & 6.3 & 55.0 \\
\hline 4. Health & 39.2 & 26.5 & 28.0 & 32.9 & 62.5 & 40.0 & 31.7 \\
\hline 5. Legal status & 30.4 & 23.0 & 5.2 & 15.7 & 12.5 & 0.0 & 16.2 \\
\hline 6. Loneliness & 10.1 & 3.0 & 0.0 & 0.0 & 43.8 & 0.0 & 4.0 \\
\hline \multicolumn{8}{|l|}{ 7. No problem } \\
\hline encountered & 10.1 & 12.4 & 16.5 & 10.0 & 12.5 & 0.0 & 11.6 \\
\hline $\mathrm{N}$ & 69 & 113 & 97 & 70 & 32 & 32 & 413 \\
\hline
\end{tabular}

${ }^{*}$ Multiple responses (1-6)

and about 12 per cent of our respondents were infected during their flight. Disease and lack of nourishment cause frequent deaths.

Two of our female respondents gave birth while fleeing. One of the births was premature and the child did not survive. The seriously ill mother was carried by fellow refugees for the rest of the journey.

\section{Arrival in the Host Environment}

Refugees do not solve their problems by the simple act of crossing an international border. In the first place, crossing international borders may not even guarantee physical inviolability or a haven of safety ${ }^{4}$. Detention and expulsion are common experiences of asylum seekers all over the world. In some countries asylum seekers are detained and subjected to long periods of confinement ${ }^{5}$. In many cases detention is an expression of the refusal to give asylum and is often followed by expulsion.

Expulsion, although on the increase (Melander, 1978), is not very common in Africa and the Sudan is not known to have returned back anybody who sought a free haven within its borders. Therefore, the problems which refugees face on their arrival in the Sudan concern more the general problems of transition than immediate threats to their physical safety. The problems are of a socio-cultural and psychological nature, due partly to the strangeness of the language and culture. It involves also the problem of mere survival. However, some writers seem to be oblivious to the consequences of flight, particularly among African peasants. Gould, for example, writes:

The African peasant may lose little or indeed has little to lose if he is forced to flee, and may have as much as the indigeneous population in the reception area even at the beginning of his exile (Gould, 1974:420).

In spite of his material poverty, the African peasant has much to lose when he is 
uprooted from his community. The little piece of land he calls his farm or garden may be unproductive but he ekes his subsistence out of it. His tukul may look miserable but it is his shelter. The community provides the peasant with a sense of security and belonging. Flight means the loss of all or most of these. It is a disruption of what is "normal life" for the peasant, even if it is a very poor one. It is thus misleading to compare the conditions of the host population with those of refugees, particularly recent arrivals.

As is apparent in Table 6.8, the problem of survival (food and shelter) was mentioned by a large percentage of our respondents. This indicates that relief assistance is inaccessible to most new arrivals - a situation which could be explained by the remoteness of the points of arrival, by lack of information and by the refugees' fear of being identified and sent back if they contacted authorities.

\section{Stress, shock and ill-health}

Cultural and socio-psychological problems are, as we shall show in Chapter 9, inevitable accompaniments to displacement. New arrivals in an alien social and cultural environment are bound to feel what is commonly known as "culture-shock". This is complicated by a sense of helplessnessfor those who enter and stay illegally in a foreign land. These problems were mentioned by 55 per cent of the respondents and were felt much more by those refugees who settled among the local population and who were immediatly "immersed" in the host environment on arrival. Those who lived in more or less homogeneous refugee settlements such as the organized rural settlements of Um Gulja and Um Rakoba were relatively, well-protected against the instant desocialization and estrangement felt by those who arrived and stayed in communities where there were few fellow countrymen.

One of the consequences of long flight journeys is bad health on or after arrival in the host country. Physical exhaustion and lack of nourishment increases the refugees' vulnerability to infectious diseases. In the case of our respondents, the change of the physical environment from the cool highlands to the hot lowlands seems to have exacerbated the problem. Consequently health problems on arrival in the host country were experienced by 31.7 per cent of the respondents. The problem was mentioned by a large proportion of respondents from each sample site.

Nevertheless, poor health was less common among those refugees who moved to organized settlements after arrival than among those stayed in the spontaneous settlements. As can be seen from Table 6.8, respondents in the organized settlements of Tawawa, Um Gulja and Um Rakoba were less affected by health problems after arrival than the self-settling refugees in Damazin, Kurmuk, Yabus, Muguf and Gedaref. This difference is due mainly to the accessiblity of free health servicesin the organized settlements. The findings indicate strongly the need to spread relief assistance to the self-settling refugees in the Sudan. Due to the health problems which accompany flight, the death rate is quite high in some of these refugee "communities". For example, in the two rural spontaneous settlements of Yabus and Muguf, 30 per cent of the children died during the first year of their stay in the Sudan. Even among the adult population, the death rate was relatively high. Within four years the 32 households which were included in our survey lost more than 20 per cent of their members. According to our informants, lack of food and malaria were the main causes of death (Bulcha, 1983). 
Health problems due to exhaustion, a change of environment, malnutrition, and diseases exacerbate the economic and socio-psychological problems which meet refugees when they arrive in the country of asylum. Sickness minimizes the refugee's possibilities of working and solving his subsistence problems, while the death of family members exacerbates physiological and psychological stress. Above all it deepens the grief which is caused by the separation from "home".

Death complicates the feelings of guilt (which as we shall discuss in Chapter 9 a large percentage of the respondents harbour) because the surviving members of the deprived household tend to feel responsible for it. For example, there were respondents who blamed themselves for the death of their children in the host country because they believed that had they stayed at home their children could have had better chances for survival.

About 16 per cent of our respondents mentioned that they had encountered problems of a legal nature on their arrival in the Sudan. These problems partly concerned state policy regulating the movement of refugees within the Sudan, and partly the acquisition of work permits and licences. Such problems, which are felt mostly by refugees with urban backgrounds, severely limit their income-earning capacity and hinder adjustment to the new environment. One of the sociological problems encountered on arrival is loneliness. This problem was felt by about 4 per cent of the respondents in our study. These were mainly single young men who had arrived in small towns.

\section{Self-help and solidarity}

Most refugees gradually find solutions to the problems encountered on arrival (Table 6.9). Those who succeed in solving "most" problems and those who fail to find solutions to any of the problems after a period of about 4 or 5 years in the host country are in the minority: 13 per cent and 10 per cent respectively. The majority, about 76 per cent, succeeded only partially in overcoming their initial problems of subsistence and shelter after about five years in the country of asylum. As we shall discuss in the next chapter, however, this may not mean self-sufficiency or satisfactory integration into the host economy.

In general, refugees accommodated in organized settlements were able to solve their initial problems of adjustment quicker than the self-settling refugees. As shown in Table 6.10, 95.8 per cent of the respondents in the organized settlements were able to find some solutions to their initial problems as compared to 78.7 per cent of the

Table 6.9 Solution of initial problems by settlement sites (\%).

\begin{tabular}{lccccccc}
\hline $\begin{array}{l}\text { Proportions of } \\
\text { problems solved }\end{array}$ & Gedaref & Tawawa & Gulja & Um & Rakoba & Kamazin Yabus & All \\
All or most & 22.6 & 18.2 & 13.4 & 6.3 & 0.0 & 0.0 & 12.9 \\
Some & 75.8 & 75.8 & 84.0 & 85.7 & 89.3 & 31.3 & 76.4 \\
Few or none & 1.5 & 6.0 & 2.5 & 3.2 & 10.7 & 68.7 & 9.9 \\
No answer & 0.0 & 0.0 & 0.0 & 4.8 & 0.0 & 0.0 & 0.8 \\
\hline Total \% & 99.9 & 100.0 & 99.9 & 100.0 & 100.0 & 100.0 & 100.0 \\
\multicolumn{1}{c}{$\mathrm{N}$} & 62 & 99 & 81 & 63 & 28 & 32 & 365 \\
\hline
\end{tabular}


Table 6.10 Solution of initial problems by type of settlement (\%)

\begin{tabular}{|c|c|c|c|c|c|c|}
\hline \multirow[t]{2}{*}{$\begin{array}{l}\text { Proportion of } \\
\text { problems solved }\end{array}$} & \multicolumn{3}{|c|}{$\begin{array}{c}\text { Organized } \\
\text { settlements }\end{array}$} & \multicolumn{3}{|c|}{$\begin{array}{c}\text { Spontaneous } \\
\text { settlements }\end{array}$} \\
\hline & Urban & Rural & Total & Urban & Rural & Total \\
\hline Most & 18.2 & 10.4 & 13.6 & 15.6 & 0.0 & 11.5 \\
\hline Some & 75.8 & 84.7 & 81.1 & 80.0 & 31.3 & 67.2 \\
\hline Few or none & 6.0 & 2.8 & 4.1 & 4.4 & 68.7 & 21.3 \\
\hline No answer & 0.0 & 2.1 & 1.2 & 0.0 & 0.0 & 0.0 \\
\hline Total \% & 100.0 & 100.0 & 100.0 & 100.0 & 100.0 & 100.0 \\
\hline $\mathrm{N}$ & 99 & 144 & 243 & 90 & 32 & 122 \\
\hline
\end{tabular}

Organized/Spontaneous $\mathrm{X}^{2}=28.32,3$ d.f., $\mathrm{p}<.001$

Urban/Rural $\mathrm{X}^{2}=23.24,3$ d.f., $\mathrm{p}<.001$.

self-settling refugees. Nearly 20 per cent of the self-settling refugees and only 4 per cent of those in organized schemes said that they had not yet succeeded in finding any solution to their problems.

The differences between the two categories of refugees in their rate of initial adjustment to the host society remaind significant even when confounding variables such as sex and length of residence are controlled. In fact of the group with all problems unsolved, the self-settling refugees had lived in the Sudan for three years on average, while those from the organized settlements had stayed in the Sudan for only two years.

Even among the self-settling refugees there are significant differences in coping with problems of adjustment. For example, 95.6 per cent of the urban respondents were able to find solutions to at least some of their initial problems as compared with only 31.3 per cent in the rural spontaneous settlements. Around 70 per cent of the rural refugees and only 5 per cent of the urban refugees were unable to ameliorate their initial adjustment problems after about 5 years in the country of asylum. It is clear from our data that the rural self-settling refugees generally find it most difficult to adjust to the host environment on arrival.

A large proportion of the respondents who solved most or some of their initial adjustment problems relied mainly on their own resources and intiatives. As revealed in Table 6.11, solution through self-help was mentioned by 45.3 per cent of the respondents. The next largest group of refugees have used humanitarian assistance to overcome their initial problems. Solidarity from relatives and countrymen who arrived earlier also plays an important role in meeting the survival needs of new arrivals. Hospitality from their hosts was mentioned by 3.3 per cent of the respondents.

The means used to solve the initial problems of adjustment differed somewhat according to the place where the refugees settled on arrival or shortly after. For instance, about 65 per cent of the self-settled respondents received no help from any source whatsoever. Nearly 35 per cent were assisted, mainly by relatives and countrymen. In comparison, only 37 per cent of respondents who arrived in organized settlement had to face their initial adjustment problems alone. The majority, 63 per cent, were assisted in one way another on their arrival. Humanitarian assistance was received by 52.6 per cent of the respondents who moved directly to organized 


\begin{tabular}{llll}
\hline Source of assistance & $\begin{array}{l}\text { Spontaneous } \\
\text { settlement }\end{array}$ & $\begin{array}{l}\text { Organized }^{\mathrm{b}} \\
\text { settlement }\end{array}$ & Total \\
\hline 1. No assistance & 64.6 & 37.0 & 45.3 \\
2. Relatives & 17.2 & 20.0 & 19.2 \\
3. Countrymen & 26.6 & 12.6 & 16.7 \\
4. Members of host society & 3.0 & 3.5 & 3.3 \\
5. Humanitarian org. & 7.0 & 52.6 & 38.9 \\
\hline Total N & 99 & 230 & 329 \\
\hline
\end{tabular}

No assistance $\mathbf{X}^{2}=21.05,1$ d.f., $\mathbf{p}<.001$. Relatives $\mathbf{X}^{2}=1.08$, not significant. Countrymen $\mathbf{X}^{2}=24.19,1$ d.f., $\mathbf{p}<.001$.

Host society $X^{2}=.00$, not significant. Humanitarian organizations $X^{2}=62.07,1$ d.f., $p<. .001$.

aultiple responses recorded for 2-5.

- Most of the respondents in this group did not arrive directly in the organized settlements but moved there afterwards.

settlements and by only 7 per cent of those who chose to live in spontaneous settlements. Solidarity among countrymen was somewhat stronger among selfsettling refugees than among those who settled in state-run schemes.

\section{Conclusion}

Since they are sparked off spontaneously by the urgency of the situation most refugee movements are, unlike voluntary migrations, not preceded by planning, preparation and deliberate choice of destination. Therefore, the flight of more than two-thirds of our respondents was characterized by panicked departure rather than by deliberation and calculated action.

Although the main reason behind most refugee movements is unfavourable change in the socio-political environment, there may be additional factors which reinforce or countervail the decision to flee. As was shown, personality could be one such factor, in a minority of cases. But our data is not detailed enough to establish personality differences between those who fled and those who stayed in spite of danger, perceived or actual.

In the case of Ethiopia one of the major factors which determines whether a person leaves the vicinity of danger is distance from international borders. Our findings indicate that the majority of respondents moved relatively short distances, as they originated from areas near to the border. In contrast, places far away from the border which have been affected by similar conditions have contributed fewer refugees.

Our study shows that the distance covered between the points of departure and settlement is a function of the demographic characteristic of the group in flight. According to our data, exiles of rural origin tend to flee shorter distances compared with those from urban backgrounds. The majority of rural refugees interviewed originated from border areas and settled at the first point of safety near the border. 
Their flight was a single-step movement, while that of urban refugees was a multiplestep and multiple-vector movement. The urban refugees did not stay at the first point of safety but moved further to major urban areas and from there to other countries of asylum in different parts of the world.

Nearly 90 per cent of refugees from Ethiopia face major problems on their arrival in the Sudan. The problems which the majority (75\%) encountered concerned subsistence and shelter. Ill-health and socio-cultural differences between the societies of origin and destination also constituted major difficulties.

The extent to which the respondents overcame these problems, as well as the time taken, varied according to type and place of settlement. Respondents who arrived in remote and less developed communities took longer to overcome subsistence problems than those who came to areas with an infrastructure and services. Those who settled in organized schemes tended to overcome their initial adjustment problems quicker than self-settling refugees, and urban refugees faster than their rural counterparts.

The assistance available to respondents on their arrival in the host country varied somewhat according to place of settlement. Very few self-settling refugees received assistance. Refugees in the organized settlements received most of their assistance from humanitarian organizations. Solidarity among refugees was stronger among self-settling groups than among those in organized settlements. It is interesting to note that the percentage of respondents who received assistance from the local people was the same in every site. The same is true of solidarity from relatives. 



\section{PART III}

\section{THE DIMENSIONS OF INTEGRATION}





\section{Chapter 7}

\section{The Economic Dimension of Integration}

\section{Introduction}

In Chapter 4 we pointed out that the first changes made by migrants or refugees in the new environment are in practical areas such as food, shelter and clothing. Cultural and socio-psychological"changes come later. This means that refugee integration in the host society commences with adjustment and absorption into the host economic system.

Economic integration is defined as "the process of securing work and becoming a part of the regularly employed labour force in a given society" (Shannon and Shannon, 1973:36). However, the acquisition of a job may not mean economic self-reliance. For refugees to be considered economically integrated in their country of asylum, they must have reached a level of material self-sufficiency. Here, the key variable is self-sufficiency. Humanitarian organizations consider refugees as selfsufficient when they reach a state which permits the withdrawal of aid (HarrellBond, 1986:2). In other words self-sufficiency concerns the ability to produce and satisfy one's own basic needs. Economic integration is, therefore, coterminous with self-sufficiency and implies a certain degree of success as productive members of that society and an attainment of a reasonable standard of living commensurate with that of the majority of the indigenous population.

\section{Conditions and Limitations}

Whether refugees and migrants are able to become productive members of their host countries is determined by two sets of factors related to the host-society and the refugees themselves. In capitalist oriented economies like that of the Sudan, the host-related factors hinge mainly upon the right to produce for one's own consumption or sale and the right to participate in the labour market without being discriminated against as an alien. This implies the absence of legal hindrances to employment, receiving wages comparable to those earned by the local people, and the right to own and run business enterprises. If the host country's economic system is socialist the right to work and share with others the goods and services that are collectively produced could be considered an indicator of economic integration. There are several refugee-related factors that have bearings on economic integration. Some of the important variables are their educational and occupational backgrounds, sex and age and most important of all the motivation, to attain self-sufficiency. Before proceeding to the main objective of this chapter, let us look at those demographic characteristics of the study population that are assumed to play an important role in the achievement of economic integration. 


\section{A Portrait of the Sample Population}

\section{The demographic structure}

The respondents in this study spoke the three major languages of Ethiopia. About 59 per cent spoke Tigrinya or Tigre, 25 per cent Amharic and about 16 per cent Oromiffa. The last group includes also the Berta refugees living in Yabus and Muguf. The majority are Christians and only 20 per cent confess Islam, the religion of the country of asylum.

As is indicated in Table 7.1 the majority of the heads of households are young. One obvious explanation for this is the "sorting out" effect of flight movement, whereby the old members of the community of origin are left behind because of their lack of physical fitness. It is also possible that older people are reluctant to uproot themselves even when a situation is threatening. According to our findings 85 per cent of the respondents were in the age range of 16-40 years and about 13 per cent were between 41 and 60 . Only 2 per cent were above 60 .

There were significant age differences between the urban and rural refugees. As can be seen in the table, nearly 70 per cent of the urban heads of households were below the age of thirty compared with 50 per cent in the rural settlements. Less than five per cent of the urban and 11 per cent of the rural respondents were above fifty.

These variations are due mainly to two factors. While it is the young and educated who flee from the urban areas of Ethiopia, flight from the rural environments is of a mass nature and is therefore less age-selective. This partly explains the relative prevalence of older men and women in the exodus from the rural areas who on arrival in the Sudan, settle mostly in rural environments. What is more, among the rural refugees, it is often the young with some school education who tend to migrate to the urban centres after an initial period of adjustment.

One of the common assumptions of international humanitarian organizations and journalistic circles is that sex ratios are grossly disproportionate in most African refugee populations. The assertion is that women and small children are in large majority and that men account for only a very small percentage of the influxes. This assumption is erroneous in the case of the Horn of Africa (Waldron, 1983; ILO, 1984b; Kibreab, 1985). Although the majority (58 per cent) of our respondents were

Table 7.1 Age of respondents by type of settlement

\begin{tabular}{lccc}
\hline \multirow{2}{*}{ Age } & $\begin{array}{c}\text { Urban/ } \\
\text { Semi-Urban } \\
\%\end{array}$ & $\begin{array}{c}\text { Rural } \\
\%\end{array}$ & $\begin{array}{c}\text { Total } \\
\%\end{array}$ \\
\hline-20 & 20.1 & 10.1 & 15.3 \\
$21-30$ & 48.4 & 40.2 & 44.4 \\
$31-40$ & 23.0 & 28.1 & 25.5 \\
$41-50$ & 3.8 & 10.6 & 7.0 \\
$51-60$ & 3.8 & 7.5 & 5.6 \\
$60+$ & 0.9 & 3.5 & 2.2 \\
\hline Total \% & 100.0 & 100.0 & 100.0 \\
$\mathrm{~N}$ & 213 & 199 & 412 \\
\hline
\end{tabular}

$\mathrm{X}^{2}=22.20,5$ d.f., $\mathrm{p}<.001$. 
Table 7.2 Distribution of sample households by number of children and type of refugees (\%)

\begin{tabular}{|c|c|c|c|}
\hline No, of children & $\begin{array}{l}\text { Urban/ } \\
\text { Semi-Urban } \\
\%\end{array}$ & $\underset{\%}{\text { Rural }}$ & $\begin{array}{c}\text { Total } \\
\%\end{array}$ \\
\hline $\begin{array}{l}\text { None } \\
1-2 \\
3-4 \\
5+\end{array}$ & $\begin{array}{r}43.9 \\
30.8 \\
20.6 \\
4.7\end{array}$ & $\begin{array}{l}25.1 \\
43.2 \\
20.6 \\
11.1\end{array}$ & $\begin{array}{r}34.8 \\
36.8 \\
20.6 \\
7.7\end{array}$ \\
\hline $\begin{array}{r}\text { Total } \% \\
\mathrm{~N}\end{array}$ & $\begin{array}{c}100.0 \\
214\end{array}$ & $\begin{array}{c}100.0 \\
199\end{array}$ & $\begin{array}{l}99.9 \\
413\end{array}$ \\
\hline
\end{tabular}

$\mathrm{X}^{2}=20.65,3$ d.f., $\mathrm{p}<.001$.

women, there were more men than women in five of the settlements covered by the study.

In the small town of Kurmuk there were virtually no female refugees according to the police register used; in Damazin they were about 30 per cent, in Um Rakoba 32 per cent, in Tawawa 32 per cent and Gedaref 46 per cent'. It was only in Um Gulja, Yabus and Muguf that the female population was in a slight majority. More than one third (34.8 per cent) of the interviewed households were childless, 36.8 per cent had one or two children and only 28.3 per cent had three or more children under the age of sixteen.

Table 7.3 indicates that 69 per cent of the heads of households were married ${ }^{2}, 16$ per cent single, 9 per cent separated or divorced, 5 per cent widowed and 2 per cent abandoned by their spouses or with spouses missing due to flight. The majority of the marriages were monogamous while about 8 per cent of the heads the households lived in polygamous relations ${ }^{3}$.

There are significant variations in the marital status of respondents from the two settlement settings. Nearly 26 per cent of the respondents from the urban and semi-urban settlements were unmarried, 60 per cent married and 14 per cent separated, widowed or with spouses missing. The corresponding rates for the rural

Table 7.3 Distribution of respondents by marital status (\%)

\begin{tabular}{lccc}
\hline Marital status & Urban/ & Rural & Total \\
\hline Unmarried & Semi-Urban & & \\
Mamed & 25.7 & 5.5 & 16.0 \\
Separated/divorced & 60.3 & 77.4 & 68.5 \\
Widowed & 7.5 & 11.0 & 9.2 \\
Spouse missing & 5.1 & 3.5 & 3.4 \\
\hline Total \% & 1.4 & 2.5 & 1.9 \\
\multicolumn{1}{c}{$\mathrm{N}$} & 100.0 & 100.0 & 100.0 \\
\hline
\end{tabular}

$\mathrm{X}^{2}=34.42,4$ d.f., $\mathrm{p}<.001$. 
Table 7.4a Distribution of sample households by type (\%)

\begin{tabular}{lccccccc}
\hline Household type & Gedaref & \multicolumn{2}{c}{ Kamazin } & Um & Um & Yabus \\
Kurmuk & Tawawa & Gulja & Rakoba & Muguf & Total \\
\hline $\begin{array}{l}\text { Single/group of } \\
\text { individuals }\end{array}$ & 30.4 & 90.6 & 10.6 & 11.3 & 14.3 & 0.0 & 20.0 \\
Nuclear family & 59.4 & 9.4 & 70,8 & 74.2 & 77.1 & 90.6 & 67.3 \\
$\begin{array}{l}\text { Extended family } \\
\begin{array}{l}\text { One parent and } \\
\text { child/ren }\end{array}\end{array}$ & 0.0 & 0.0 & 1.8 & 0.0 & 1.4 & 9.4 & 1.5 \\
\hline Total \% & 10.1 & 0.0 & 16.8 & 14.4 & 7.1 & 0.0 & 11.1 \\
\hline $\mathrm{N}$ & 99.9 & 100.0 & 100.0 & 99.9 & 99.9 & 100.0 & 99.9 \\
\hline
\end{tabular}

areas were 6 per cent unmarried, 77 per cent married and 17 per cent widowed or spouses missing.

Family disintegration. The incidence of family disintegration was significant among the sample population. Urban refugees showed marked signs of family breakdown with about 42 per cent of the households consisting of one parent families, single people or unrelated male adults. The corresponding proportion was 20 per cent for the rural households. All in all households consisting of one or a collection of adults constituted 20 per cent of the sample. Most often there is no kinship between the occupants. A household of this category has, in the absence of the family, some social, psychological and economic function. However it is much more important as a place of abode for its occupants who are brought together by fate, common cultural heritage, perhaps similar political affiliations but, most important of all, the inability to foot individually the exhorbitant rents demanded by house owners in the shanty towns.

Although about two-thirds of the respondents lived in nuclear families, the male-head of household was often absent working elsewhere in the Sudan or the Middle East, or fighting in Ethiopia in one of the guerrilla movements. In contrast to the society of origin, only 1.4 per cent of the respondents lived in extended families. About 11 per cent of the households consisted of one-parent and children families. The single parent in such a household was often a mother who was widowed,

Table 7.4b Type households by type of refugee (\%)

\begin{tabular}{lccc}
\hline Hosehold type & $\begin{array}{c}\text { Urban/ } \\
\text { Semi-Urban } \\
\%\end{array}$ & $\begin{array}{c}\text { Rural } \\
\%\end{array}$ & $\begin{array}{c}\text { Total } \\
\%\end{array}$ \\
\hline Singlelgroups of adults & 29.0 & 10.6 & 20.0 \\
Nuclear familiy & 57.5 & 77.9 & 67.3 \\
Extended family* & 0.9 & 2.0 & 1.5 \\
One parent and & & 9.5 & 11.1 \\
child/ren household & 12.6 & 100.0 & 99.9 \\
\hline Total \% & 100.0 & 199 & 413 \\
\hline
\end{tabular}

$\mathbf{X}^{2}=25.2,3$ d.f., $\mathrm{p}<.001$

* Families with members from three generations. 
Table 7.5a Distribution of heads of household by sex (\%)

\begin{tabular}{|c|c|c|c|c|c|c|c|}
\hline Sex & Gederef & $\begin{array}{l}\text { Damazin } \\
\text { Kurmuk }\end{array}$ & Tawawa & $\begin{array}{l}\text { Um } \\
\text { Gulja }\end{array}$ & $\begin{array}{l}\text { Um } \\
\text { Rakoba }\end{array}$ & $\begin{array}{l}\text { Yabus } \\
\text { Muguf }\end{array}$ & Total \\
\hline $\begin{array}{l}\text { Male } \\
\text { Female }\end{array}$ & $\begin{array}{l}85.5 \\
14.5\end{array}$ & $\begin{array}{r}93.7 \\
6.3\end{array}$ & $\begin{array}{l}81.4 \\
18.6\end{array}$ & $\begin{array}{l}80.4 \\
19.6\end{array}$ & $\begin{array}{l}84.3 \\
15.7\end{array}$ & $\begin{array}{r}100.0 \\
0.0\end{array}$ & $\begin{array}{l}84.7 \\
15.3\end{array}$ \\
\hline $\begin{array}{l}\text { Total } \\
\end{array}$ & $\begin{array}{c}100.0 \\
69\end{array}$ & $\begin{array}{c}100.0 \\
32\end{array}$ & $\begin{array}{c}100.0 \\
113\end{array}$ & $\begin{array}{c}100.0 \\
97\end{array}$ & $\begin{array}{c}100.0 \\
70\end{array}$ & $\begin{array}{c}100.0 \\
32\end{array}$ & $\begin{array}{c}100.0 \\
413\end{array}$ \\
\hline
\end{tabular}

divorced or abandoned by her husband. Generally, our data reveal some of the abnormal characteristics of the refugee household: relatively high divorce rates, missing spouses and single parent families which are more frequent than in any social setting in Ethiopia. In contrast to households in Ethiopia and the Sudan, the refugee household was often small, incomplete and disorganized. However, the structure and sue of the households differed somewhat according to the type of settlement. On the average, households in the study consisted of five persons. This corresponds to the findings of most of the researchers who have conducted surveys among refugees in eastern Sudan (Jonsson 1982; ILO, 1984b; Kibreab, 1985).

\section{Female heads of household}

One of the most remarkable features of the refugee communities in the Sudan is the frequent occurrence of households headed by women. Various research reports indicate that between 20 and 30 per cent of the refugee households are headed by women. This is very striking because the refugees' societies of origin are patrilineal and patrilocal. The change seems to have taken place mainly because of the exigencies of flight and the process of uprooting. ${ }^{4}$

As shown in Table 7.5 a about 15 per cent of all the households surveyed had women as household heads. The frequency varied from settlement to settlement with the state-organized, wage-earning settlements topping the list, followed by the spontaneous urban settlements of Damazin and Gedaref. The spontaneous rural settlements of Yabus and Muguf contained no households that had women as family heads. However, when the households were dichotomized into urban and rural categories no significant difference was observed. Fifteen per cent of both the urban and the rural heads of household were female. There was significant variation between spontaneous and organized settlements. Among the self-settling house-

Table 7.5b Distribution of heads of household by sex and type of refugees and settlement (\%) .

\begin{tabular}{lcccccr}
\hline Sex & Urban & Rural & Total & Spontaneous & Organized & Total \\
\hline Male & 84.6 & 84.9 & 84.7 & 91.2 & 82.1 & 84.7 \\
Female & 15.4 & 15.1 & 15.3 & 9.8 & 17.9 & 15.3 \\
\hline Total & 100.0 & 100.0 & 100.0 & 100.0 & 100.0 & 100.0 \\
\multicolumn{1}{c}{ N } & 214 & 199 & 413 & 133 & 280 & 413 \\
\hline
\end{tabular}

Urban/Rural $\mathrm{X}^{2}=0.07,1$ d.f., not significant.

Spontaneous/Organized $X^{2}=5.60,1$ d.f., $p<.02$. 
10 per cent had female household heads whereas the proportion was almost twice as high in the organized settlement.

In general the results of our survey show lower rates of female heads of household than other studies. The differences are accounted for by two main reasons. Firstly, almost all of the other studies were based on samples taken from urban refugee communities and organized rural settlements and do not include self-settling rural refugees. Secondly, families whose male heads of household were away to work were considered, de facto, as female-headed households ${ }^{5}$. Consequently they obtained higher percentages of female-headed households. In our survey samples are taken from all categories of refugees and types of settlements and only women who were single, divorced or abandoned or whose husbands were missing at the time of survey were considered as heads of household.

\section{Educational backgrounds of the respondents}

Education is one of the most important variables influencing economic integration. As shown in Table 7.6, nearly 75 per cent of the heads of household had had no school education at all, which means that they were illiterate. Only 15 per cent of the respondents had some primary schooling, about 8 per cent had attended secondary schools and nearly $\mathbf{3}$ per cent had university education. Those with university education were concentrated in the bigger urban centre of Gedaref. The low level of education among the study population reflects the literacy rate in the country of origin.

\section{Occupational profiles: comparisons between the past and the present}

Although the major concern of economic integration is earning the means of survival, the type of jobs that refugees perform can, to some extent, serve as an indicator of their absorption into the economic and social stream of the host society. In many countries, refugees and immigrants belong to the most disadvantaged sections of the population and are unable to get employment which is considered "respectable". They are forced by circumstances to undertake the worst paid and most socially undesirable jobs, and are often employed in marginal and seasonal occupations and menial work (Richmond and Verma, 1978:8).

Table 7.7 gives a condensed picture of the occupational structure of the study

Table 7.6 Respondents' level of education by type of settlement (\%)

\begin{tabular}{llcr}
\hline & Urban/ & & \\
Education & Semi-Urban & Rural & Total \\
\hline No schooling (not literate) & 62.6 & 87.9 & 74.8 \\
Elementary school & 21.5 & 8.0 & 15.0 \\
Secondary school & 10.7 & 4.0 & 7.5 \\
College/university & 5.1 & 0.0 & 2.7 \\
\hline Total \% & 99.9 & 99.9 & 100.0 \\
$\mathrm{~N}$ & 214 & 199 & 413 \\
\hline
\end{tabular}

$\mathrm{X}^{2}=35.30,3$ d.f., $\mathrm{p}<.001$. 
Table 7.7 Occupational status of respondents before and after flight (\%)

\begin{tabular}{lcc}
\hline Occunation & Previous & Present \\
\hline 1. Subsistence farming & 23.0 & 9.2 \\
2. Farm labourer & 7.9 & 16.9 \\
3. Petty trade/shop assistant & 6.1 & 12.3 \\
4. Semi-professional, military, & & \\
clerical jobs, teaching etc. & 9.2 & 5.8 \\
5. Student & 4.1 & 0.0 \\
6. Construction and factory work & 0.7 & 0.7 \\
7. Handcraft & 1.9 & 3.1 \\
8. Domestic work & 6.1 & 3.4 \\
9. Guard & 1.9 & 1.9 \\
10. Food and beverage sellers & 1.9 & 9.9 \\
11. Water and fire-wood vendors & 0.0 & 1.5 \\
12. Others & 8.3 & 2.6 \\
13. Housewife & 18.9 & 15.2 \\
14. No employment & 9.9 & 17.5 \\
Total \% & 99.9 & 100.0 \\
$\quad \mathrm{~N}$ & 413 & 413 \\
\hline
\end{tabular}

population. As is depicted in the table the refugees' present jobs match their previous occupational background to a large extent. However, this is not enough to ascertain occupational integration or "job satisfaction". To do that we need to examine the conditions of employment (duration and security), income and other related variables.

Except for 'student' the same occupations are mentioned in both the pre- and post-flight columns. The number of respondents employed in the sector and in the traditional occupation of farming have decreased. The proportion of those who are employed in the informal sector, particularly those branches which are called "survival occupations" like agricultural wage employment, petty-trade, handicraft, brewing and selling alcohol, collection and sale of fire-wood, charcoal and water have increased markedly. Of course, there is nothing surprising about this. Since these people are involuntary immigrants who came to the Sudan without prior preparation such changes are expected. Given the economic conditions of the Sudan the changes are inevitable. Nevertheless, the implications of these changes for adjustment and integration in the host environment deserve some comment.

The shift from formal occupation to casual wage employment involves a shift from relative material well-being to poverty. The various activities which individuals create in the informal economic sector do provide an income to sustain life. But they rarely produce enough income as the respondent households spent most of whatever they made on food but still were not free from malnutrition.

Occupation is not only an indicator of individual material well-being. It is also a symbol of status. It determines not only the evaluation of 'self' by others but it influences self-esteem. Hence mobility from socially prestigious and satisfying occupations to non-prestigious or even despised occupations can, with some individuals, result in maladjustment and lack of self-respect. It is doubtful whether a decent ex-housewife who for the sake of the survival of her children and herself has taken up prostitution, or a decent ex-student who has become a procurer for the 
same existential reasons could ever regain their self-esteem and the respect of others, despite being forced by circumstances to act the way they have.

The occupational changes that were brought about by flight are sociologically interesting in other ways. If we look at the situation in social structural terms, for a large proportion of the respondents flight involves a far reaching sociological transformation. A large section of refugees with peasant backgrounds experienced what could be called social class transformation in exile. These former owner-cultivators were turned into casual wage labourers. This in itself is a big change because for most of them wage employment is not only a new experience but is probably their 'proletarization' for the rest of their lives. However, the most profound social transformation is experienced by the former nomads. The majority of the nomadic clans who have fled the wars in Eritrea over the last twenty years are today sedentarized and have become wage-labourers and cultivators (Kibreab, 1985:109). Normally social transformation of such a degree would take several decades. In the case of these refugee groups the transformation, catapulted through time and space by the circumstances surrounding flight and the needs of survival, took place almost over night.

The transformation was not limited to the mode of the production of material means of existence. It involved changes in social relations. Nomadic families who lived in small clan groups in the hot lowlands, and peasant households who lived in scattered hamlets in the highlands of northern Ethiopia were brought together with tens of thousands of their country men and settled in 'villages' located on the edges of modern mechanized farms. The change, given the speed with which it took place and the alien environments in which it occurred, entails great social-psychological stress for peasants and nomads. These problems will be discussed in more detail in later chapters.

\section{Employment: First Step Towards Integration}

For refugees and immigrants social and economicintegration into their host societies begins with the process of securing a job. But this occurs only after long delays for many refugees, and may not take place at all in some cases. Refugees are handicapped in many ways on the labour market in their countries of asylum. The inability to speak the local language, the mismatch between the refugee's occupational backgrounds and experiences with those required and the unavailability of language and job-training services are some of the obvious obstacles to early entry into the labour market of the host country.

At the time of our survey 66.3 per cent of the sample were either self-employed or earning a wage, 15.2 per cent were housewives with the husband employed. Only 17.5 per cent were unemployed. Compared to employment rates in many developing countries, the above figures depict a positive picture. However, this picture is misleading because the data were collected during the harvesting season. As employment is seasonal or casual for most of the respondents, it is necessary to look at the whole year in order to avoid a seasonal bias.

Table 7.8 gives a summary of the length of employment (for refugees in the sample) for 1982 . The employment statistics show that 21.8 per cent of the inter- 
Table 7.8 Length of employment (\%)

\begin{tabular}{|c|c|c|c|c|c|c|c|}
\hline Months & Gedaref & $\begin{array}{l}\text { Damazin } \\
\text { Kurmuk }\end{array}$ & Tawawa & $\begin{array}{l}\text { Um } \\
\text { Gulja }\end{array}$ & $\begin{array}{l}\text { Um } \\
\text { Rakoba }\end{array}$ & $\begin{array}{l}\text { Yabus } \\
\text { Muguf }\end{array}$ & Total \\
\hline $\begin{array}{l}0-3 \\
4-8 \\
9-12\end{array}$ & $\begin{array}{l}23.2 \\
10.1 \\
66.7\end{array}$ & $\begin{array}{r}3.1 \\
9.4 \\
87.5\end{array}$ & $\begin{array}{l}24.8 \\
35.4 \\
39.8\end{array}$ & $\begin{array}{l}28.7 \\
35.1 \\
36.1 \\
\end{array}$ & $\begin{array}{l}21.4 \\
25.7 \\
52.9\end{array}$ & $\begin{array}{r}6.3 \\
37.5 \\
56.2 \\
\end{array}$ & $\begin{array}{l}21.8 \\
27.6 \\
50.6\end{array}$ \\
\hline $\begin{array}{r}\text { Total } \% \\
\mathrm{~N}\end{array}$ & $\begin{array}{c}100.0 \\
69\end{array}$ & $\begin{array}{c}100.0 \\
32\end{array}$ & $\begin{array}{c}100.0 \\
113\end{array}$ & $\begin{array}{c}99.9 \\
97\end{array}$ & $\begin{array}{c}100.0 \\
70\end{array}$ & $\begin{array}{c}100.0 \\
32\end{array}$ & $\begin{array}{c}100.0 \\
413\end{array}$ \\
\hline
\end{tabular}

viewed heads of household were unemployed or employed for only 1 to 3 months of the whole year, 27.6 per cent were employed between 4 and 8 months and one half between 9 and 12 months. The average period of employment for the whole sample was 7.3 months.

However, unemployment and under-employment are not uniform phenomena but vary depending upon the type of refugees and the type of settlement. Thus, as is shown in Table 7.9,21 per cent of the urban refugees were employed in 1982 for less than 4 months, 23.4 per cent between 4 and 8 months and 55.6 per cent between 9 and 12 months. The corresponding rates for rural refugees was 22.6 per cent for less than 3 months, 32.2 per cent between 4 and 8 months and 45.5 per cent between 9 and 12 months. These figures indicate that there is a higher incidence of unemployment and under-employment in the rural refugee communities than among groups that have settled in urban settings.

A more significantassociation is found between the type of settlement and the rate of employment. As can be seen in the right-hand part of Table 7.9, 25.3 per cent of the respondents interviewed in organized settlements were employed less than 3 months, 32.9 per cent between 4 and 8 months and 41.8 per cent between 9 and 12 months. Among the self-settling refugees the corresponding rates were 14.3 per cent (0-3 months), 16.5 per cent (4-8 months) and 69.2 per cent (9-12 months).

The higher incidence of unemployment and under-employment in the rural and organized settlements is mainly accounted for by the fact that agriculture is the predominant means of livelihood in these sites. Agricultural activity whether on owned fields or as wage labour is highly seasonal in the Sudan.

Weeding and harvesting durra and cotton are the two major agricultural activities

Table 7.9 Length of employment by type of refugees and type of settlement (\%)

\begin{tabular}{|c|c|c|c|c|}
\hline \multirow[b]{2}{*}{ Months } & \multicolumn{2}{|c|}{ Refugees } & \multicolumn{2}{|c|}{ Settlement } \\
\hline & Semi-Urban & Rural & Organized & Spontaneous \\
\hline $0-3$ & 21.0 & 22.6 & 25.3 & 14.3 \\
\hline $4-8$ & 23.4 & 32.2 & 32.9 & 16.5 \\
\hline $9-12$ & 55.6 & 45.2 & 41.8 & 69.2 \\
\hline Total \% & 100.0 & 100.0 & 100.0 & 100.0 \\
\hline $\mathrm{N}$ & 214 & 199 & 280 & 133 \\
\hline
\end{tabular}

Urban/Rural $\mathbf{X}^{2}=5.3$, not significant. Organized/Spontaneous

$\mathbf{X}^{2}=27.82,2$ d.f., $\mathbf{p}<.001$. 
Table 7.10 Length of employment by level of education (\%)

\begin{tabular}{lcccc}
\hline \multicolumn{5}{c}{ Level of education } \\
\hline \hline Months & $\begin{array}{l}\text { No formal } \\
\text { education }\end{array}$ & $\begin{array}{l}\text { Elementary } \\
\text { school }\end{array}$ & $\begin{array}{l}\text { Secondary/ } \\
\text { College }\end{array}$ & Total \\
& 23.8 & 19.0 & 12.2 & 21.8 \\
\hline $0-3$ & 31.7 & 20.6 & 7.3 & 27.6 \\
$9-8$ & 44.5 & 60.4 & 80.5 & 50.6 \\
\hline Total & 100.0 & 100.0 & 100.0 & 100.0 \\
$\mathrm{~N}$ & 309 & 63 & 41 & 413 \\
$\mathrm{X}$ & 6.8 & 8.1 & 9.8 & 7.3 \\
\hline
\end{tabular}

$X^{2}=20.55,2$ d.f., $p<.001$; No formal education/Elementary school $X=4.091$ d.f., $p<.05$; No formal education/Secondary-College $X^{2}=18.69,1$ d.f., $p<.001$; Elementary school/Secondary-College $X=4.64,1$ d.f., $\mathrm{p}<.05$.

which employ rural migrant labour in eastern Sudan. Together, these activitiescover about five or six months of the year. The general absence of other forms of employment forces the agricultural labourers into about six months of unemployment. The unemployment period is often much longer for these refugees as employment is not readily available at the beginning of each season. Farm labourers spend weeks looking for job before they get contracts.

Competition among the ever-increasing refugee population and the Sudanese migrant-labourers is rising very rapidly because of the gradual shrinkage in peasant agriculture and herds of the nomads. The encroaching desert and the expanding commercial agriculture are taking more and more land each year from these traditional sectors and are undermining the means of subsistence for a large segment of the Sudanese population. Hence peasants and nomads are seeking employment as wage labourers often away from their traditional homes. The competition between the expanding Sudanese rural proletariat and the refugees is not only reducing the chances of employment but is also reducing wages.

Drought often complicates the situation. A slight failure in rainfall drastically cuts employment opportunities. Refugees and seasonal wage labourers lack material savings and traditional social security networks. Therefore, a crop failure which affects local Sudanese farmers mildly could prove a major catastrophe for the majority of the refugee households. Unemployment means starvation unless one has access to humanitarian assistance.

One of the variables that we found to have a considerable bearing on employment was the level of education. The data in Table 7.10 show that unemployment and under-employment decreases with a rise in the level of education. Thus, the average length of employment in 1982 was 6.8 months for respondents without formal education, 8.1 months for those with some elementary schooling and 9.8 months for those who with some secondary and/or college educational backgrounds.

These observations show that refugees in eastern Sudan with formal qualifications and skills have greater opportunities to earn their subsistence than those without qualifications. This does not mean that they were engaged in tasks commensurate with their training and skills. Some of them were doing menial work. The fact that most of the well-educated were employed by humanitarian organizations with 
short-term plans in the Sudan may also make their relative success a temporary one.

The higher employment rate recorded for these respondents should not be generalized for all educated refugees in the Sudan since research reports from other areas in the country show a different picture. El Dawi (1979: 12) and Jerry Weaver $(1985: 153)$ have noted that many educated refugees from Ethiopia live for years in a state of suspension in Khartoum, some of them now and then employed at menial tasks while others survive on handouts from families and friends. The conditions for the Ugandan refugees in the south seem no better. Barbara Harrell-Bond notes that highly educated, experienced and skilled professionals are expected by aid agencies to make their living through subsistence agriculture (1986:251).

\section{Meeting Basic Needs and Achieving Self-Sufficiency}

Employment by itself is not sufficient to determine economic self-sufficiency,particularly in a developing country, unless income is taken together with it. The rate of employment does not necessarily tell us whether a household or an individual has earned sufficiently to meet basic needs. Refugees, for example, can be engaged full-time all the year round either working on their own allotments or for others but that may not guarantee sufficient returns to meet their survival needs. Therefore, it is necessary to make an assessment of household income to determine the economic self-sufficiency of the respondents and the viability of the various forms of settlement implemented by the government of the Sudan as the solution to the refugee problem.

This endeavour, however, raises two major problems. The first is how to measure income in a country like the Sudan where regular wage employment is not the main source of income for the vast majority of the population. Furthermore, about a third of our respondents were subsistence farmers, handicraftsmen, petty-traders, etc., whose incomes varied from season to season and in some cases from one month to the next. Even among wage-earning respondents the employment histories were characterized by irregularity and seasonality.

Our only means of overcoming these problems was by coaxing the respondents to recall how much they earned over the last $\mathbf{1 2}$ months from the various activities in which they were engaged. Although the incomes were meagre and often sporadic most of the respondents were able to remember what they had earned, while others gave us crude estimates based on their food consumption and goods they have bought during that period. Another problem with measuring income, particularly in rural households, is the possible diversity of their source of income and the difficulty in coverting them into monetary estimates. In our case, this was not a major problem since the rural householders were either farm labourers or subsistence farmers who cultivated just one crop, durra, the value of which can be estimated from the amount harvested.

Problems of measuring self-sufficiency

In order to reach fairly reliable quantitative estimates of household incomes we persuaded respondents to recall every pound and piastre they earned from wagelabour, handcraft, petty-trade, charcoal, fire-wood and water peddling, the selling of 
Table 7.11 Estimated income levels for existence minimum and self-sufficienthouseholds (1982-83)

\begin{tabular}{|c|c|c|}
\hline Amenities & Existence minimum (£S) & Self-sufficient ( $£ S$ ) \\
\hline 1. Food & 450 & 600 \\
\hline 2. Clothing & 100 & 200 \\
\hline 3. Miscellaneous & 75 & 100 \\
\hline Sub total (rural) & 625 & 900 \\
\hline 4. Shelter (urban) & 200 & 300 \\
\hline Sub total (urban) & 825 & 1200 \\
\hline 5. Social costs & - & 100 \\
\hline 6. Education & - & 30 \\
\hline Total & $625-825$ & $1030-1330$ \\
\hline
\end{tabular}

$£ S=$ Sudanese pounds.

bamboo poles, livestock, poultry and in some cases even vegetable-gardening. Those who were self-employed cultivators were asked how much they harvested during the last season. In our estimates we excluded income which respondents received without labour. This income came from gifts, remittances, humanitarian aid or handouts. The latter two are very crucial sources of supplementary income for many refugee households. Their exclusion from household income estimates is motivated by the fact that unlike earned income they cannot constitute a measure of economic self-reliance.

When compared with the results of other studies (cf.ILO, 1984a) the figures we obtained are higher for some occupations and lower for others. However, as we made it very clear to each respondent that the aim of the survey was academic and that the results would not be used to harm or benefit them in any way, we consider the figures obtained to be honest, albeit very crude, estimates which could with caution be generalized to the entire population at the various sites.

The problem of assessing respondent economic self-sufficiency also concerns the answers to the following two questions: a) what are the basic economic needs of a refugee household? and b) what is the minimum income required by a refugee household to meet its basic needs? The literature that deals with socio-economic development make a distinction between 'first floor' and 'second floor' human needs. The first floor needs are the minimum human needs such as food, clothing, shelter, health and education. The second floor needs concern the quality of life rather than the issue of survival (McHale and McHale, 1978). Here we are concerned with the first type of basic needs.

It is also often difficult to estimate the minimum level of income required to cover basic household needs in countries like the Sudan which lack price control on basic commodities and where food prices fluctuate severely depending upon the season. However, we asked refugees in the various settlements about their daily, weekly and monthly expenditures on basic amenities and services. By combining this information with that obtained from our own observations, and investigation of the prices of basic commodities, we were able to draw a rough quantitative income scale based on 
an "existence minimum floor" with regard to meeting "absolute" needs, and a "self-sufficiency floor" for an average refugee household both in the urban and rural settings (see Table 7.11). The existence minimum or absolute needs floor includes only those elements such as food, shelter, clothing and medication which are essential for physical survival. The income level mentioned in this connection is therefore close to the margins of survival. The "self-sufficiency floor" is the level at which basic needs, both physiological and social, are satisfied and a living standard at some desirable level beyond marginal survival is maintained. The social needs in this context includes social obligations such as expenditures on funerals, weddings, feasts and celebrations. As shown in the table, the absolute needs floor lies between $£ 625$ (for rural) and $£ 825$ (for urban households). The differences emerge because the rural refugees usually build their own tukuls and have no rent.

\section{Validity of the scale}

It is interesting to note that the "existence minimum and self-sufficiency scale" we have proposed is similar to income estimates mentioned by other sources as amounts needed by refugee households to meet their needs. For example, in 1980 COR estimated £S 900 as a sum commensurate with annual refugee household expenditure (Documentation for Khartoum Conference, Vol.II,1980:27). Elgaali (1982:80) proposed that the average annual income needed by an average refugee household was from $£ S 600$ to 700 . Kibreab $(1985: 269)$ mentions $£ S 700$ as the minimum income needed by a peasant refugee household living in the organized land settlements of Eastern Sudan for its survival.

The basic survival needs levels set by us and the other sources referred to are based on what we outsiders (researchers) felt should and could be normally sufficient for survival and self-reliance. Nevertheless, in order to qualify as a valid instrument for the analysis of needs and economic integration our scale of viablehousehold incomes should correspond to what the majority of the subjects feel is sufficient for their survival. In order to find this out, we asked the respondents two questions:

1. How much did you and your household earn last year?

2. Was your income sufficient to meet the basic needs of your household, i.e., food, shelter, clothing and medication?

We rated the household income (based on answers to question 1) as 'sufficient' or 'insufficient' and cross-tabulated these answers with the respondents' answers to question 2 (also given as 'sufficient' or 'insufficient') to test the validity of the income scales given in Table 7.11.

Our findings show that the proportion of households whose income we rated as 'sufficient' was nearly the same as the proportion of respondents who answered that their income was sufficient for minimal existence - 38 per cent and 36.4 per cent respectively (Table 7.12). According to our ratings 62 per cent and according to respondents 63.6 per cent of the households earned an average annual income below the 'existence minimum'.

In the majority of the cases (76 per cent), our ratings and respondents' opinions regarding sufficiency of household income for existence minimum, were in agreement. This concurrence between respondent experience and our ratings makes our 'existence minimum - self-sufficiency' scale valid for the analysis of the economic conditions of the study population. But before that some comment on the 24 per cent 
Table 7.12 Distribution of respondents by sufficiency of income for existence minimum

\begin{tabular}{llll}
\hline $\begin{array}{l}\text { Subjective } \\
\text { (Respondent) } \\
\text { ratings }\end{array}$ & $\begin{array}{l}\text { Ratings according to objective } \\
\text { conditions (prices) }\end{array}$ & at time of \\
\cline { 2 - 3 } & Survey & Total \\
\hline Sufficient & Sufficient & Not sufficient & \\
Not sufficient & 25.2 & 11.1 & 36.3 \\
\hline Total & 12.9 & 50.7 & 63.6 \\
$\quad \mathrm{~N}$ & 38.1 & 61.8 & 99.9 \\
\hline
\end{tabular}

whose answers did not concur with our ratings is in order. The heads of 44 households (12.9 per cent) whose incomes we rated as 'sufficient' replied 'insufficient' whereas, among those whose income we considered as 'insufficient', 38 heads of households (11.1 per cent) replied that their incomes were 'sufficient' for basic needs. A closer look at these families showed that the former had mainly larger and the latter smaller households than the sample average of five persons on which our figures in Table 7.11 are based.

\section{Income Distributions of Sample Population}

Approximately 83 per cent of the respondents (341 households) answered fully our questions on income. About 17 per cent ( 72 households) were either reluctant to mention their income or were unable to recollect how much they earned the previous year. As shown in Table 7.13, nearly 23 per cent of the respondents did not earn any income in 1982 and had to depend for survival on humanitarian assistance, help from relatives or loans.

About 19 per cent earned annual average incomes below $300 ; 20.5$ per cent earned

Table 7.13 Distribution of annual income by settlement site (\%)

\begin{tabular}{lccrrrrr}
\hline & & & Um & Um & \multicolumn{2}{c}{ Damazin Yabus } & \\
Income $(£ S)$ & Gedaref & Tawawa & Gulja & Rakoba & Kurmuk & Muguf & Total \\
\hline 0 & 18.3 & 19.4 & 27.8 & 23.6 & 3.7 & 44.4 & 22.6 \\
$1-229$ & 3.3 & 9.7 & 8.9 & 18.2 & 81.4 & 55.6 & 19.0 \\
$300-599$ & 6.7 & 24.7 & 39.2 & 16.4 & 11.1 & 0.0 & 20.5 \\
$600-899$ & 13.3 & 32.3 & 15.2 & 16.4 & 0.0 & 0.0 & 17.3 \\
$900-1199$ & 11.7 & 3.2 & 5.1 & 10.9 & 3.7 & 0.0 & 6.2 \\
$1200-1499$ & 25.0 & 6.5 & 3.8 & 5.5 & 0.0 & 0.0 & 7.9 \\
$1500+$ & 21.7 & 4.3 & 0.0 & 9.0 & 0.0 & 0.0 & 6.5 \\
\hline Total \% & 100.0 & 100.0 & 100.0 & 100.0 & 99.9 & 100.0 & 100.0 \\
$\mathrm{~N}$ & 60 & 93 & 79 & 55 & 27 & 27 & 341 \\
\hline
\end{tabular}

Between 13 and 18 per cent of the respondents did not answer this question in each settlement. 
between £S 300 and $£ S 599,17.3$ per cent between $£$ S 600 and $£ S$ 899; 6.2 per cent between $£ S 900$ and $£ S 1199,7.9$ per cent between $£ S 1200$ and $£ S 1499$ and the rest, 6.5 per cent, $£ S 1500$ or above. The data indicates that above two-thirds of the respondents were unable to achieve economic self-reliance and were therefore on the brink of starvation. About one-third were self-reliant. Only 14.4 per cent of the families interviewed can be considered to be economically self-sufficient households.

What are the reasons for the lack of economic self-reliance? Why is it that only some households achieve self-sufficiency while others are unable to earn enough for existence minimum? Does the host environment offer them unequal opportunities? Is the length of residence in the host society the determinant factor in economic self-reliance? Is there a relationship between demographic variables and economic self-reliance in exile?

Since these questions have policy implications we shall investigate them in some detail.

\section{Length of residence in host country}

The common assumption underlying refugee aid programmes in Africa is that, after a given period of time - usually estimated to be four or five years - refugees will achieve a certain degree of economic self-sufficiency. In the 1960s, rural settlements were expected to achieve self-sufficiency in two or three years (Pitterman, 1984:126). In the 1970s the period was extended to five years. Such specifications are usually made to determine dates for the withdrawal of humanitarian and development assistance. The assumptions and date determinations were naturally made in the belief that the chances of employment would increase and the productive capacity and income of the refugee households would improve with the passage of time.

Experience has shown otherwise in several host countries including the Sudan. As Table 7.14illustrates, the length of residence in itself seems to have little relationship to improvement in the material standard of refugee households. The incidence of material poverty was as frequent among those who have been in the Sudan between 4 and 8 years as those who had been there just a year or two. Neither were the differences between the newcomers and those who had been in the host country over 8 years strikingly significant. Thus 63.7 per cent of those with 1 to 3 years residence, 61.5 per cent with 4 to 8 years and 46.6 per cent of those with 9 or more years of residence in the Sudan were earning incomes below the existance minimum level. A

Table 7.14 Length of residence by annual income (\%)

\begin{tabular}{cccc}
\hline Income $(£)$ & $0-3$ years & $4-8$ years & $9+$ years \\
\hline-599 & 63.7 & 61.5 & 46.6 \\
$600-1199$ & 21.0 & 23.8 & 33.3 \\
$1200+$ & 15.3 & 14.7 & 20.0 \\
\hline Total \% & 100.0 & 100.0 & 99.9 \\
$\mathrm{~N}$ & 124 & 202 & 15 \\
\hline
\end{tabular}

$\mathrm{X}^{2}=0.68 ; 2$ d.f.; not significant. 
survival income had been reached by only 21 per cent of the 1-3 year cohort, 23.8 per cent of the 4-8 year group and 33.3 per cent of those who had lived in the Sudan 9 or more years. The proportions of those who have achieved economic self-sufficiency among the three groups were not significantly different either, being 15.3 per cent among the first, 14.7 per cent in the second and 20 per cent in the third. The income differentiations are greater within each cohort group than between them.

Given the objective conditions which clearly indicate the inevitability of prolonged sojourn in the Sudan for the majority of the refugees, these findings are quite alarming. The implication is prolonged dependency and destitution unlessefforts are redoubled, more inputs are made and new ways of helping these people to pull themselves out their dire conditions are mapped out and implemented.

\section{Gender and economic self-reliance}

It is common knowledge that women are more vulnerable than men to the difficulties created by conditions of exile. Moreover, refugee households headed by women are the most vulnerable in the community of vulnerables created by exile. Table 7.15 compares the economic conditions of households headed by men and women. The data reveal that unemployment (no income) is two and half times (48.1 per cent) more frequent among female-headed households than among other households (18.3 per cent). The proportion of female headed households earning an income below the existence minimum is greater ( 69.2 per cent) than those headed by men (60.2 per cent). The proportion of male heads of household that have achieved economic self-sufficiency, or are earning annual incomes averaging 1200 or more is almost twice (16.3 per cent) that of the females ( 9.6 per cent).

There are several factors that give rise to this positive relationship between economic vulnerability and gender. In countries like the Sudan where cultural and religious values tend to confine women to the home, the possibilities for single women and widows to earn their living are greatly reduced. When and where it is possible for women to work outside the home the unavailability of suitable jobs for women makes economic self-reliance impossible. Language problems often hinder educated female refugees from resuming their previous secretarial and service occupations.

Unemployment and the disruption of the traditional protection provided by the extended family often force single women and those who are of household heads to enter the socially despised occupations of prostitution and the illegal selling of alcohol. Refugee women become even more insecure when they enter these occupations. As we noticed and were also told by respondents, the homes of such women are subject to frequent police raids which obviously have negative consequences for the household.

There are women refugees who seek employment as maid-servants and migrate to the Gulf states. Since their employment is arranged by middle-men who work covertly it is impossible to say how many women migrate each year in this manner. However, there are indications that their numbers are substantial. It has been reported that between 1977 and 1978, more than 6000 such women migrated from the Sudan with Saudi-Arabia and the other Gulf States as destinations (Badume and Tesfaye, 1981:5). These women may solve their economic problems but they become even more vulnerable and insecure in other respects. In the Arab countries, there is 
Table 7.15 Income distribution by sex of household head (\%)

\begin{tabular}{cccc}
\hline Income $(£ S)$ & Male & Female & Total \\
\hline 0 & 18.3 & 48.1 & 22.6 \\
$1-299$ & 21.1 & 3.8 & 19.0 \\
$300-599$ & 20.8 & 17.3 & 20.5 \\
$600-899$ & 18.0 & 17.3 & 17.3 \\
$900-1199$ & 5.5 & 3.8 & 6.2 \\
$1200-1499$ & 8.7 & 3.8 & 7.9 \\
$1500+$ & 7.6 & 5.8 & 6.5 \\
\hline Total \% & 100.0 & 99.9 & 99.9 \\
$\mathrm{~N}$ & 289 & 52 & 341 \\
\hline
\end{tabular}

no organization that gives legal protection to these women. There are indications that once they enter domestic service they are confined to the home and turned into virtual slaves, and may not be able to free themselves easily.

The plight of women refugees, particularly when they happen to be single or widowed heads of household is such that they need more attention. Some attempts are being made by humanitarian organizations to meet the particular needs of these women. The Sudan Council of Churches (SCC) and Sudan Aid (SA) offer some vocational training in handicrafts, sewing, embroidery and spinning. However, these activities, as we saw them in Um Gulja, are planned for markets outside of the Sudan. It is doubtful that such products can compete in the international market and bring in an income on which these women can survive. Therefore, it is probably wiser to produce goods that are in greater demand in the Sudan itself.

\section{Occupation and self-reliance}

As we have seen in the foregoing section, a large percentage of the household heads interviewed were employed as casual labourersor as petty-traders, craftsmen, and so on in the informal sector. Income from these type of activities can keep starvation away but does not offer much opportunity for mobility and self-sufficiency. The data in Table 7.16 makes this point very clear. The findings in the table show a clear

Table 7.16 Respondents by main occupation and average annual income (\%)

\begin{tabular}{|c|c|c|c|c|}
\hline \multirow[t]{2}{*}{ Occupation } & \multicolumn{4}{|c|}{ Income $(£ S)$} \\
\hline & -599 & $600-1199$ & $1200+$ & Total (\%) \\
\hline \multicolumn{5}{|l|}{ 1. Peasant } \\
\hline 2. Farm labourer & 62.9 & $\begin{array}{r}2.0 \\
30.0\end{array}$ & $\begin{array}{l}2.0 \\
7.1\end{array}$ & 100.0 \\
\hline 3. Petty trader ${ }^{1}$ & 70.6 & 13.7 & 15.7 & 100.0 \\
\hline \multicolumn{5}{|l|}{ 4. Semi-professional } \\
\hline 5. Catering ${ }^{\mathrm{z}}$ & 25.0 & 12.5 & 62.5 & 100.0 \\
\hline $\begin{array}{l}\text { 5. Catering } \\
6 \text { Handcraft }\end{array}$ & 48.9 & 34.0 & 17.1 & 100.0 \\
\hline \multirow{2}{*}{$\begin{array}{l}\text { 6. Handcraft } \\
\text { Others }\end{array}$} & 50.0 & 33.3 & 16.7 & 100.0 \\
\hline & 60.5 & 31.6 & 7.9 & 100.0 \\
\hline
\end{tabular}

${ }^{1}$ Kiosk owners, peddlers of various commodities.

${ }^{2}$ Food and beverage seller. 
relationship between occupation and economic self-sufficiency.Subsistencefarming is the occupation that provides the least possibility for self-reliance. Nearly 95 per cent of those who had farming as their main source of subsistence earned incomes that place them under the existence minimum. Petty trade offers somewhat better opportunities with a comparatively lower percentage (70.6 per cent) earning annual average income under $£ S 600$. The more permanent types of employment in the professional, semi-professional and clerical occupations give better possibilitiesfor economic self-reliance. According to our findings, only 25 per cent of those doing such jobs were earning below £S 600. In fact 62.5 per cent of them as compared to only 2.6 per cent of the subsistence farmers could be considered as having achieved relative self-sufficiency. The data demonstrate clearly that respondent households whose heads are engaged in farming occupations, whether self-employed or wageearning, and those relying on casual jobs in the informal sector are the poorest of the sample population.

\section{Type of refugees and settlements}

The refugee category to which respondents belonged and the type of settlement in which he/she lives comprise another set of variables that have a close relationship with economic self-reliance. Consequently, comparisons between the economic performance of urban and rural refugees show that the urban setting offers, in general, better opportunities than rural environments. Table 7.17 shows that nearly one half of the respondents from the urban and semi-urban sample were earning annual average incomes of $£$ S 600 or more as compared to only about one-fourth of their compatriots interviewed from the rural sample sites. The difference in the economic viability of the two categories of households becomes even more pronounced if we take into consideration the fact that 21 per cent of those from the urban and only 6.7 per cent from the rural settings can be categorized as economically self-sufficient. According to the data 51.7 per cent of the urban and 73.9 per cent of the rural households were earning incomes below what we consider sufficient for existence minimum. This corresponds roughly to the personal assessment of the respondents themselves. It underlines the fact that urban refugees are more likely to become self-reliant and are better integrated into the Sudanese labour market. The relationship between economic self-sufficiency and the type of settlement is also quite significant, although not as strong as that between self-sufficiency and rural/ urban location. Although the proportion of the self-settling refugees with incomes below the existence minimum level was almost the same as those living in the organized settlements (61.4 per cent and 62.4 per cent respectively), there were nearly three times as many self-sufficienthouseholds in the spontaneous settlements as in the organized settlements (24.6 per cent cf. 9.2 per cent). However, these aggregate figures conceal one important fact. The income opportunities vary widely within the spontaneous settlement category. In fact self-settling refugees in Yabus and Muguf (Table 7.13 ) were the poorest group in the whole study sample. The spontaneous urban settlements, particularly in the larger towns like Gedaref, provide better economic opportunities.

The differences between the urban and rural refugee household incomes are explained by a number of factors, the main ones being demographical and structural. As noted earlier, urban refugees tend to be male, single and better educated. They 
Table 7.17 Income distribution by type of refugee and settlement (\%)

\begin{tabular}{ccccc}
\hline & \multicolumn{2}{c}{ Refugee } & \multicolumn{2}{c}{ Settlement } \\
\cline { 2 - 5 } Income $(£ S)$ & Urban/ & Rural & Spontaneous & Organized \\
& Semi-Urban & & & \\
\hline $0-599$ & 51.7 & 73.9 & 61.4 & 62.6 \\
$600-1199$ & 27.2 & 19.3 & 14.0 & 28,2 \\
$1200+$ & 21.1 & 6.8 & 24.6 & 9.2 \\
\hline Total \% & 100.0 & 100.0 & 100.0 & 100.0 \\
$\mathrm{~N}$ & 180 & 161 & 114 & $\mathbf{2 2 7}$ \\
\hline
\end{tabular}

Urban/Rural $\mathrm{X}^{2}=26.09,4$ d.f., $\mathrm{p}<.001$. Spontaneous/Organized $\mathrm{X}^{2}=20.334$ d.f., $\mathrm{p}<.001$.

possess better skills and work experiences which generate higher economic rewards than is the case with occupationally homogeneous rural refugees. The urban environment provides better opportunities not only for wage-employment but also for self-employment, even if it is not profitable entrepreneurship in most cases. Thus the opportunity structure is more complex, with a wider variety of occupations yielding better rewards than in the rural areas. According to our findings, the 69 heads of household interviewed in Gedaref were employed in 22 different fields of economic activities. In the semi-urban organized settlement of Tawawa located on the outskirts of Gedaref 14 types of occupations were reported by the 113 respondents. The advantage with the urban setting is that refugee households make use of the different opportunities in various combinations. Petty-trade is often combined with occasional wage-labour. Family members engage in different activities to bring in income. Some urban refugees in Gedaref, Tawawa and Damazin combine urban wageemployment with seasonal agricultural wage labour in the surrounding countryside.

This is not often possible in the rural settlement. For obvious reasons, opportunities dwindle as we move farther and farther from the urban areas into the countryside. In the organized rural settlement of Um Gulja the 97 heads of household we interviewed were occupied in only nine different economic activities, in Um Rakoba in only six and in the rural spontaneous settlements of Yabus and Muguf in the border districts, subsistence farming was the only source of income. The refugee households in these remote areas have little opportunity to augment their income from agriculture as other opportunities are very scarce. When wage employment is available the remunerations are so low that it is inadequate even to sustain a single person let alone a whole family of five or more. In 1982, wages as low as 25 piastres were paid for a day's work during the weeding season, although the daily wage was eight times that in other districts in the same region (ILO, 1984a:120). As mentioned before, lack of information about labour market conditions in other areas, restrictions upon their movement and above all their desire to remain near to the border and their abandoned homes tie them down in the misery of want. The marginal, non-agricultural activity occasionally carried out by refugees to supplement their income is petty trade. Petty trade is done through bartering goods in the small settlements of the area and with the nomadic Fallata herdersmen. This activity brings in very little income for the refugees but benefits the local money lenders on whom they depend for working capital.

The other activity, cutting and selling bamboo sticks, is carried out by most of the 
men in the Yabus and Muguf area during the dry season. The bamboo is bought by local traders and hauled by lorry to the northern part of the country where it is in demand as a building material. However, the refugees make very little income from this activity as they are forced to enter intosheil debt during the lean months between the harvests, particularly during the rainy season when their food stock is exhausted. Sheil is usually a form of mortgage which involves crops or other products of labour that are given by the loan giver in the future. In Yabus and Muguf, sheil is paid back in bundles of bamboo poles during the dry season. The sheil takers are unable to sell their bamboo to the highest bidder but are obliged to deliver to the loan giver at a very low price.

The conditions in the organized rural land and wage settlements are not much better regarding job opportunities. Agricultural employment is seasonal. Agricultural activity provides employment for a period of six months every year in the Sudan. During the rest of the year the rural population are either unemployed or underemployed. Wages are very low even during the peak seasons and few agricultural labourers can survive on their wages for the whole year. Shortage of cultivable land, the lack of inputs and, drought, also render farming a non-viable source of subsistence.

\section{Survival Strategies}

Respondents who reported that they were unemployed and/or underemployed during some of the seasons and those who said that their income was not enough to meet their basic needs were asked to describe how they survived during the difficult periods. The responses are reported in Table 7.18. The data indicate that humanitarian assistance was used by 17.4 per cent of these needy refugee households during the periods of unemployment. Humanitarian assistance is accessible mainly to rural refugees living in organized settlements. The vast majority ( 90 per cent) of the self-settling refugees both in rural and urban settings do not receive humanitarian assistance even when they find themselves in very difficult situations.

There are, however, various other means of survival used by refugees in times of the utmost difficulty. Assistance and solidarity mainly in the form of remittances from refugee relatives working in the Middle East, Europe, the United States and in some cases even in the Sudan itself was received by 15.8 per cent of the respondents. The incidence of remittance varies according to type of refugee. Thus urban refugees received remittance more frequently than the rural households.

Other research reports also indicate the crucial role this source of assistance plays in the survival of thousands of refugee households in the Sudan. It was reported that 30.5 per cent of the total monthly income of the refugee households in the city of Port Sudan came from remittances in 1982 (ESRC, 1982:100). According to this source remittance from relatives working abroad constitutes the second largest means of survival, surpassed only by wages and salaries. There are even those who propose that remittance coming to refugees is an important source of foreign currency for the Sudanese state (Elias, 1982:29). Considering the size of the refugee population in the Sudan and the rather large proportion of households which receive remittances we get the same impression. However, it would be wrong to draw conclusions here since 
our data does not indicate the amount received by respondents as individuals, households or as aggregates.

Another means of survival during the lean months is loans. About one-third of households ( 32 per cent) depended upon loans to carry themselves through periods of unemployment and scarcity. The system is used more frequently by self-settling refugees ( 45.8 per cent) than by those who live in organized settlements (26.5 per cent), and more by rural (34.9 per cent) than urban refugee households ( 28 per cent). Loans are obtained from local money lenders. The loan givers are individuals because the refugees do not have any sort of mutual credit associationsand because they are denied the use of formal financial institutions such as banks and other credit facilities. Refugee based voluntary associations are not wide-spread and provide very limited assistance.

When the lenders are refugees the amount in cash or kind which can be borrowed is very small and, according to our respondents, interest is seldom paid. Solidarity rather than profit is the motive here. Such behaviour is an element of the social interdependence that characterizes Ethiopia, particularly in the rural areas. Hence, contrary to what is often assumed about refugees, normative social behaviour seems not to have been significantly eroded in this case by the experience of exile. But it should be pointed out that most of the borrowers and lenders are relatives, neighbours and acquaintances. Those who lack such social relations are rarely helped by this system. Researchers of disaster have noted elsewhere that increased solidarity during crisis does not work indiscriminately but that there is an ordering of who are helped first, second and so on, Individuals will first help their family and kin and then other persons (Hulthker and Trost 1976:6-7). Therefore being together with one's family and kin could reduce not only anxiety, but will also have adaptive value by enhancing the chances of the individual surviving.

Refugees borrowed from Sudanese money-lenders less often than they do from other refugees. This is, among other things, because of the very high interest rate involved.

Sporadic income-generating activities constituted the last resort for 17 per cent of the households when returns from their "main" means of livelihood are insufficient

Table 7.18 Source of supplementary income in times of shortage or unemployment by type of settlement and refugees (\%)

\begin{tabular}{lcccccc}
\hline & \multicolumn{3}{l}{ Settlement } & \multicolumn{3}{l}{ Refugees } \\
\cline { 2 - 7 } Source of income & $\begin{array}{l}\text { Spon- } \\
\text { taneous }\end{array}$ & $\begin{array}{l}\text { Organ- } \\
\text { ized }\end{array}$ & Total & $\begin{array}{l}\text { Urban/ } \\
\text { Semi- } \\
\text { Urban }\end{array}$ & Rural & Total \\
\hline $\begin{array}{l}\text { 1. Humanitarian } \\
\text { assistance }\end{array}$ & 9.7 & 20.4 & 17.4 & 10.3 & 22.6 & 17.4 \\
2. Remittances and assist- & & & & & & \\
$\quad \begin{array}{l}\text { ance } \\
\text { from relatives }\end{array}$ & 12.5 & 17.1 & 15.8 & 23.4 & 10.3 & 15.8 \\
3. Savings & 9.7 & 20.4 & 17.4 & 19.6 & 15.6 & 17.4 \\
4. Loan & 45.8 & 26.5 & 32.0 & 28.0 & 34.9 & 32.0 \\
5. Casual employment & 15.6 & 14.9 & 17.0 & 13.1 & 19.7 & 17.0 \\
6. Reduced consumption & 34.7 & 13.8 & 19.8 & 11.2 & 26.0 & 19.8 \\
\hline & 72 & 181 & 253 & 107 & 146 & 253 \\
\hline
\end{tabular}

Multiple responses recorded. 
to meet their basic needs. In the urban areas and the larger settlements, wage-labour was combined with petty-trade. Some of the female food-sellers and brewers were forced to indulge in prostitution in order to augment their income. Farmers who were unable to produce enough to sustain their families from their own plots resorted to occasional wage-labour. Since the rural households experienced food shortages during the rainy season they engaged in wage-labour when they were most needed on their own plots. The overlapping of the period of acute need and the peak seasons of agricultural activity has both advantages and disadvantages. Labour is in demand on the bigger farms of the rich Sudanese and it is possible to eke out an income that can keep one's family alive. But it inevitably results in decreased producation on the family plots. Families thus enter a viciouscircle of perpetual scarcity and need which is very difficult to break unless some support is provided for some years, during the months of acute shortage.

It is not every refugee household in acute need that can count on humanitarian aid assistance from relatives, loans from other refugees, even causal wage labour or other sources of supplementary income. For about 20 per cent of the households there was little way of avoiding starvation during the periods of scarcity and unemployment. The problem is prevalent in all types of settlements but self-settling refugees in the rural environments are the most affected. Whether they were able to supplement their incomes or not, our findings indicate that the majority of the refugee households were far from economic self-sufficency and integration. They lived in poverty, hovering on the margins of existence.

\section{Absolute and relative poverty}

Poverty is looked at in different ways. Most sociologists describe the living conditions of the poor. But some objective standards such as income levels are also used to define poverty. In some affluent societies a household is considered "poor" if its annual income is less than three times the cost of the minimal diet for the people in that family (Baldridge, 1975:225). In general poverty is defined either in relative or absolute terms (McHale and McHale, 1978:32). Absolute poverty implies closeness to survival margins in the satisfaction of basic needs. Such poverty is chiefly the problem of societies in the Third World where large sectors of the population exist below subsistence levels.

Relative poverty refers to the condition of groups who fall far below the average standards in a country. It does not often imply any severe lack of basic amenities and is a problem in the economically developed nations (ibid, p.36). The nature of the poverty affecting refugee households becomes even clearer when we examine the adequacy of the incomes earned for basic existential needs. Using this rather crude measurement, we found that 145 ( 35.5 per cent) of the respondents spent almost 100 per cent of their total income just on food and had nothing left over to cover other needs. Nearly one half of the sample households spent between 76 and 95 per cent of their total on food), 53 (12.8 per cent) of the households between 51 and 75 per cent and only 16 (3.9 per cent) of the households up to 50 per cent. About 40 per cent (167 households) had something left over after food and shelter needs were met.

When aggregated, the refugee households spent about 90 per cent of their income on food alone. In addition, a large percentage of these families were constantly on the verge of starvation and malnutrition. Reports from even older settlements also 
Table 7.19 Distribution of households by percentage* of total income spent on basic needs

\begin{tabular}{lccc}
\hline $\begin{array}{l}\text { Percentage of } \\
\text { total income }\end{array}$ & $\begin{array}{l}\text { Food and water } \\
\text { (\% Respondents) }\end{array}$ & $\begin{array}{l}\text { Shelter } \\
\text { (\% Respondents) }\end{array}$ & $\begin{array}{l}\text { Other** } \\
\text { (\% Respondents) }\end{array}$ \\
\hline-0 & - & 62.7 & 59.8 \\
$1-15$ & 0.2 & 19.9 & 25.9 \\
$16-30$ & 3.4 & 14.0 & 13.1 \\
$31-50$ & 12.8 & 3.1 & 1.2 \\
$51-75$ & 47.9 & 0.2 & - \\
$76-95$ & 35.5 & - & - \\
$96-100$ & 99.8 & 99.8 & 100.0 \\
\hline Total \% & 341 & 341 & 341 \\
N & & & \\
\hline
\end{tabular}

${ }^{*}$ Rough estimates given by respondents.

** Clothing, medication, schooling, etc.

indicate a very high incidence of malnutrition, among children as well as adults.

There is a general assumption that refugees in Africa, particularly those from Ethiopia, flee from poverty and that their conditions in exile cannot thus be worse than those they left behind. Our findings contradict this assumption. For many of the refugees, poverty - often absolute poverty - is the consequence of flight. When asked to compare their present with their former standard of living, 74 per cent of the respondents answered that they had become poorer, 18 per cent had the same standard of living and 6 per cent were better off.

Although one must view such subjective evaluations critically, the above responses are generally supported by a statistical comparison of the respondents' pre-flight and present ownership of property. Nearly 67 per cent of the respondents said that they had owned property, in the form of domestic animals, farms, plantations, grain stores, bank deposits, business etc. At the time of the survey only 12 per cent had a few possessions which could be considered as property.

Other indicators of absolute poverty

By any measure the majority of our respondents could only be classified as living in absolute poverty. Nearly all of them lived in very crowded conditions. The average dwelling space of the households was about 2.5 square metres per member. An average of five persons, used each hut for living, cooking, sleeping, socialising and storage. More than 26 per cent of the households shared their single-room tukuls with one or more households, often strangers. In urban areas about 50 per cent of the households surveyed shared their dwelling facilities with other families as a means of reducing rental payments.

The congested living conditions of the refugee households have a bad effect upon their health. The morbidity rate seemed to be high among the refugees and at the time of the survey 54 per cent of the interviewees were having health problems. About 56 per cent of those who complained of poor health reported that they had contracted the diseases after flight. About 13 per cent were known tuberclosis patients, a disease which spreads under crowded living conditions. Tuberculosis constitutes a major health problem among refugees (Elamin,1982:3). 
Even in Qala el Nahal, one of the long established and relatively prosperous settlements, there is a high incidence of malnutrition and morbidity. About 73 per cent of the children under five years suffer from diarrhoea and 70 per cent from repeated malaria. About 80 per cent of the population are said to sufferfrom various severe infectious diseases (El-Bushra, 1982). The implications of such a high rate of morbidity for the economic self-sufficiency of households is clear.

The dysfunctional linkages between different sorts of deficiencies accentuate the condition of the needy, particularly at absolute poverty levels. Poor nutrition lowers disease resistance. Hunger and ill-health impair productivity which, in turn, lessens the capacity to secure more food, improve general living, (sic) and be more resistant to disease. It is a viciouscircle of social and economic deprivation (McHale and McHale, 1978:31).

The sociological impacts of the housing conditions are several. Adequate shelter is one of the core human needs and many of the basic needs are satisfied in relation to the home - food preparation and storage, child care, early socialization and education. Much of the satisfaction of social and psychological needs are also clustered around the household. Congestion or overcrowding thwarts the satisfaction of these needs.

\section{Conclusions}

The economic integration of refugees in the Sudan is far from reaching the targets and expectations of the host government and UNHCR. Unemployment and underemployment rates are very high among all types of refugees. Only a minority have jobs of a permanent nature. The majority are dependent on seasonal and casual wage-labour employment. Incomes are very low and the majority of refugee households find it extremely difficult to fend for themselves. A large proportion depend on the support of relatives and other countrymen or aid from humanitarian organizations. The fact that the majority of the refugees were not self-sufficient, despite the efforts they themselves, the Sudanese goverment and the international humanitarian organizations have made, is mainly attributable to the problems which the Sudanese economy has been facing in recent years.

Instant impoverishment is a common phenomenon in refugee communities all over Africa (Chambers, 1979). In the Sudan, several factors interact in causing absolute poverty among refugees. Some of these relate to the demographic characteristics of the sample population and the individual backgrounds of respondents; others relate to the structure and shortcomings of the Sudanese economy.

A large percentage of the refugees were dependent on wage employment often in the agricultural sector. Agriculture provides employment for about five to six months during good years. A general lack of other forms of employment forces labourers in this sector into about six months of unemployment or under-employment each year. The rapid increase in the proletarian population in the Sudan because of the general impoverishment of the peasant and nomadic communities has saturated the unskilled labour market and depressed wages below survival levels. The low wages offered and the long periods of separation from the family meant that, some respondents did not consider it worth their while to take agricultural wage 
labour. Instead they depended on handouts from their kin or from humanitarian organizations.

The lack of legislation regulating wages in the agricultural sector exposes labourers to exploitation which has exacerbated their poverty. Refugees are not only paid less but are in some cases refused remuneration for their labour (ILO,1984a:64-67). Refugees are also exploited in various other ways. They are made to pay more for commodities and services than the market price. The exploitative relations between members of the local community and refugees are also found in other parts of Africa where there are large concentration of refugees (Gasarasi, 1976:161; Betts, 1980:68).

Among those refugees who were engaged in subsistence farming the inadequacy of the arable land at their disposal and the insecurity of tenure when land was rented limited the productive capacity of the refugee households. This was particularly evident in the land settlement of Um Rakoba, where, at the time of the survey, only 15 per cent of the respondents had been allotted land. Constraints on mobility, particularly from rural to urban areas and between urban centres, was another factor which had a negative effect upon economic self-sufficiency. Lack of work permits and licences was a further impediment to self-reliance among urban refugees.

Refugees tend to perceive their sojourn in the Sudan as transient in spite of the fact that many of them have lived there over a decade. This must be viewed as positive thinking because, when circumstances allow, it will be easy to prepare them for voluntary repatriation. But at the same time, it creates a constant dilemma since they are unwilling to make an effort to improve their conditions in the host country. Even the host government and the international organizations who are in charge of the provision and administration of assistance hesitate to plan for long-term or lasting solutions, often for the same reason. Experience shows that this has been a mistake. Repatriation dates are often indefinitely prolonged and, even if repatriation does eventually take place, development investment could be of benefit to local populations. 


\section{Chapter 8 \\ The Social Dimension of Integration}

\section{Introduction}

Social integration here refers to the way in which the refugee relates to the social environment in the country of asylum. Hence, the main purpose of this chapter is to find out if and how respondents interact with their hosts. The questions we asked were, therefore, whether they formed interpersonal relationships, intermarried, entered into voluntary organizations or were involved in conflicts with their hosts.

George Homans proposes that "the more frequently persons interact with one another, the stronger their sentiments of friendship for one another are apt to be" (1965:133). Thus, social integration starts with the establishment of contacts between refugees and their hosts. It is through social interaction that barriers are removed, attitudes change and differences ironed out. Common interests are recognized and accommodations made only if interaction takes place. Here accommodation refers to the mutual adjustment of groups that retain their own identity and interest.

The social consequences of uprooting for the individual are estrangement and alienation. Family support, kin ties and primary and secondary group relations are broken. In the villages from which most of the respondents originate the boundary between the family and the surrounding community is fluid. The family provides its members with links to the community. Hence an individualis an integral part of both of these mutual support system. Cohesion and acceptance are taken for granted. Flight "desocializes" the individual as he/she is uprooted from these social surroundings.

The loss experienced by the break-up of ties of kinship, friendship and peer support because of uprooting is ameliorated when personal relations are re-established in the host surroundings. Resocialization in the new community is possible when such relations are entered into and maintained. Stone (1973:190) emphasizes that the development or non-development of friendship with the members of the host society is a crucial element in the immigrants' social integration. Interpersonal relationships and primary group relations are the basis for the development of common values and the recognition and pursuit of common interests. The refugee can learn about his new community more closely only by entering into such relationships with members of the host society. These relations are also indicators of social acceptance in the new community.

Apart from primary group social interaction, the secondary group serves as an important factor in strengthening the ties between immigrants and the host society. Membership in voluntary associations and clubs in which both immigrants and non-immigrants are members constitutes an important social link between them (Breton, 1964). Even immigrant-based voluntary associations play important in- 
tegrative roles. They function as substitutes for the traditional social structures such as the family and kinship groups. They cushion separation from the family and community by providing a basis for mutual support and acceptance among members (Little, 1965; Radecki, 1979). Thus the refugee who belongs to a voluntary association avoids loneliness which otherwise could lead him/her to anomie. As Durkeim (1951) argues, social isolation and the subsequent lack of social control are conditions that favour anomic behaviour.

The antithesis of social integration is social conflict. Conflict arises for a variety of reasons. In host-refugee relations it can result from poor communication, false perceptions, and incompatibilities in cultural and religious practices and values. The frequency of conflict between refugees and members of the host society is a good indicator of their tolerance, acceptance and integration.

Situational factors and variables that concern the background of refugees as individuals and as groups influence integration in the host society. Heterogeneous societies are more accommodative of differences while homogeneous societies are less open for interaction and accommodation. Such societies are likely to demand some uniformity of values, behaviour and culture. Even physical features may sometimes affect social acceptance in such societies. Refugees who seek asylum in such societies often experience profound social isolation and maladjustment even when self-sufficiency is achieved in the economic sphere.

As a heterogeneous society, the Sudan is perhaps more accommodating and puts less demands on immigrants for conformity. But that does not always guarantee quick and smooth social integration. In both homogeneous and heterogeneous societies, refugees are often blamed for social and economic problems, particularly if they are large in number. Consequently their relations with the host society are marked by hostility and conflict. Social integration is not only determined by host society factors but also by the social and cultural backgrounds of the exiles. Refugees originating from culturally homogeneous societies may find it more difficult to integrate than those from heterogeneous settings. Orthodoxy in religious and cultural orientations could block entrance into meaningful social contacts, interaction and relations with the hosts. This aspect of integration will be discussed in Chapter 9 .

Another factor which plays a relatively important role in integration is the policy of the host government. In Africa, this concerns mainly rural refugees who are sheltered in organized settlements:

Social integration . . . is the most difficult aspect of the final phase of systematically settled refugees. The difficulties here are sometimes heightened by the host government's attitude toward integration. While unfailingly generous in giving asylum and relief to rural refugees, the African governments have been slow in promoting real integration and slower with regard to naturalization. The stringent security regulations in force in some rural settlements have also served to curtail integration (Holborn, 1975: 911).

Social integration is not easy to plan or implement. It cannot be wholly determined by government decrees since much of its success depends on socio-cultural compatibility between the in-migrating and indigenous communities. However, it can be facilitated and strengthened by sound policies regulating the pattern of settlement, housing, information to combat prejudices, provision of language training services, the integration of refugee children and youth in the educational institutions of the host country and so on. 


\section{Social Interaction and Informal Relationships Between Respondents and Hosts}

We asked respondents if they had "peer" relations or contacts with Sudanese. The response was that only 18.9 per cent had established and maintained such relations (Table 8.1). About 81 per cent did not have friends among the local people whom they visited at home or vice-versa. Of those who had established informal relationships with Sudanese families or individuals only about 20 per cent had frequent contacts, while the majority socialized with them only sporadically. In general, in both the formal and informal spheres of interaction, there is a considerable distance between the respondents and the local population. For most respondents contact with Sudanese at the work place is marginal. At the institutional level, contact except for children who attended government schools between members of the two communities was very rare.

\section{Variables in host-refugee relationships}

Interaction between the respondents and the local population were influenced most by gender, knowledge of Arabic and type of settlement. Economic and religious factors also tend to impinge on social relations.

\section{Knowledge of Arabic}

Our findings indicate that in spite of the relatively short period of residence in the Sudan, the low literacy rate and the lack of help for language learning, many respondents have made some progress in learning Arabic, the language of their hosts. About 3 per cent said that they spoke fluent Arabic, 19 per cent sufficiently functional Arabic, about 37 per cent some or very little Arabic and $\mathbf{4 1}$ per cent no Arabic. The knowledge of Arabic varied from household to household. In only 24 per cent of the households could all members speak Arabic. About 49 per cent had one or more members who had learnt some Arabic whereas in 25 per cent of the households there was not a single member who spoke Arabic. In general, spontaneous settlements were found to be much more conducive to the learning of Arabic than organized and spatially segregated settlements.

As could be expected, the results or this study show a strong relationship between knowledge of Arabic and refugee-Sudanese social relations. This is so because, in a given social setting, the power to integrate depends primarily on the power to

Table 8.1 Frequency of informal personal relations between respondents and Sudanese by sample sites

\begin{tabular}{|c|c|c|c|c|c|c|c|}
\hline Relations & Gedaref & Tawawa & $\begin{array}{l}\text { Urn } \\
\text { Gulja }\end{array}$ & $\begin{array}{l}\text { Urn } \\
\text { Rakoba }\end{array}$ & $\begin{array}{l}\text { Damazin } \\
\text { Kurrnuk }\end{array}$ & $\begin{array}{l}\text { Yabus } \\
\text { Muguf }\end{array}$ & Total \\
\hline $\begin{array}{l}\text { Yes } \\
\text { No }\end{array}$ & $\begin{array}{l}37.7 \\
62.3\end{array}$ & $\begin{array}{r}5.3 \\
94.7\end{array}$ & $\begin{array}{r}3.1 \\
96.9\end{array}$ & $\begin{array}{r}2.9 \\
97.1\end{array}$ & $\begin{array}{l}68.9 \\
31.1\end{array}$ & $\begin{array}{l}53.1 \\
46.9\end{array}$ & $\begin{array}{l}18.9 \\
82.1\end{array}$ \\
\hline $\begin{array}{c}\text { Total } \% \\
\mathrm{~N}\end{array}$ & $\begin{array}{c}100.0 \\
69\end{array}$ & $\begin{array}{c}100.0 \\
113\end{array}$ & $\begin{array}{l}100.0 \\
97\end{array}$ & $\begin{array}{l}100.0 \\
70\end{array}$ & $\begin{array}{l}100.0 \\
32\end{array}$ & $\begin{array}{l}100.0 \\
32\end{array}$ & $\begin{array}{c}100.0 \\
413\end{array}$ \\
\hline
\end{tabular}


Table 8.2 Knowledge of Arabic by informal personal relations between respondents and Sudanese (\%)

\begin{tabular}{|c|c|c|c|}
\hline \multirow[t]{2}{*}{ Relation } & \multicolumn{3}{|c|}{ Knowledge of Arabic } \\
\hline & None & Good & Fluent \\
\hline $\begin{array}{l}\text { Yes } \\
\text { No }\end{array}$ & $\begin{array}{l}11.8 \\
88.2\end{array}$ & $\begin{array}{l}35.4 \\
64.6\end{array}$ & $\begin{array}{l}76.9 \\
23.1\end{array}$ \\
\hline $\begin{array}{r}\text { Total \% } \\
\mathrm{N}\end{array}$ & $\begin{array}{c}100.0 \\
321\end{array}$ & $\begin{array}{c}100.0 \\
79\end{array}$ & $\begin{array}{c}100.0 \\
13\end{array}$ \\
\hline
\end{tabular}

$\mathrm{X}^{2}=34.68,1$ d.f., $\mathrm{p}<.001$.

communicate. For most of the respondents lack of Arabic impairs their communcation and friendship formation with the local people. As is shown in Table 8.2, only 11.8 per cent of the respondents who had no or very little knowledge of Arabic were able to establish close contacts with their hosts. About 35 per cent of those who spoke sufficiently functional Arabic and nearly 77 per cent of those who spoke fluent Arabic had established closer relations with the local population.

\section{Gender}

The respondent's gender plays a very important role in contact formation with Sudanese. As shown in Table 8.3a, nearly 30 per cent of the male and only 10 per cent of the female respondents had established close social contacts with their hosts. Gender has considerable impact on the respondent's overall social integration in Sudanese society. Compared to male respondents, 78.7 per cent of whom spoke at least some Arabic, only 43.9 per cent of the female respondents were able to communicate in Arabic (Table 8.3b). Only 21.3 per cent of the male as compared to

Table 8.3a Informal personal relations by gender of respondent (\%)

\begin{tabular}{lcc}
\hline Relation & Male & Female \\
\hline Yes & 29.9 & 10.0 \\
No & 70.1 & 90.0 \\
\hline Total \% & 100.0 & 100.0 \\
$\quad$ N & 174 & 239 \\
\hline
\end{tabular}

$\mathrm{X}^{2}=26.42,1$ d.f., $\mathrm{p}<.001$.

Table 8.3b Knowledge of Arabic by gender (\%)

\begin{tabular}{lcc}
\hline $\begin{array}{l}\text { Knowledge of } \\
\text { spoken Arabic }\end{array}$ & Male & Female \\
\hline Some & 78.7 & 43.9 \\
None & 21.3 & 56.1 \\
\hline Total \% & 100.0 & 100.0 \\
$\mathrm{~N}$ & 174 & 239 \\
\hline
\end{tabular}

$\mathrm{X}^{2}=50.13,1$ d.f., $\mathrm{p}<.001$. 
56 per cent of the female respondents could not communicate at all in Arabic. This is mainly accounted for by the relative segregation of women in the host society. However, the comparatively low level of literacy among women is also a contributing factor. The disadvantaged position of female refugees affects not only their own socio-economic integration but, as indicated in the foregoing chapter, that of their entire household. When women head a household, as they often do, their role as the family breadwinner is very difficult to fulfil. Female headed households find it particularly difficult to eke out a living since Islamic culture and Sudanese mores greatly restrict their employment opportunities. Women are segregated and treated more or less as legal inferiors to men under sharia. Those who also happen to be refugees are among the hardest hit by the rising tide of religious intolerance because their occupational and physical mobility is further curtailed (Weaver, 1985:153).

\section{The spatial factor in refugee-Sudanese relations}

At the time of the field-work about 80 per cent of the refugees from Ethiopia were self-settling whereas the remaining 20 per cent were accommodated in organized settlements. The relationship between the type of settlement and the frequency of refugee-Sudanese social relations is very significant. As can be seen in Table 8.4, only 4 per cent of the respondents in organized settlements had informal personal relations with their hosts as compared with 49 per cent in the self-settling communties. About 96 per cent of the respondents in the organized and 51 per cent in the spontaneous settlements lacked close personal contacts with members of the local community.

A breakdown of the settlement types into sub-categories and locations (urban, semi-urban, rural) reveals that there was some variation in the frequency of social relations among self-settling refugees (Table 8.5). For refugees in the organized settlements the effect of location (urban/rural) upon social relations with Sudanese was negligible. This demonstrates the negative effect of spatial segregation on social interaction and integration. The findings indicate that the organized settlements, whether in rural or semi-urban settings, were relatively isolated. Spatial segregation of this nature evidently provided few opportunities for encounters between the members of the two communities and hence blocked the development of neighbourly feelings. What this implies is that organized settlements may not be socially viable as a long-term solution to the refugee problem.

The data indicate also that spontaneous settlement encourages social proximity

Table 8.4 Distribution of respondents having informal personal relations with Sudanese by type of settlement

\begin{tabular}{|c|c|c|}
\hline Relations & $\begin{array}{l}\text { Organized } \\
\text { settlements }\end{array}$ & $\begin{array}{l}\text { Spontaneous } \\
\text { settlements }\end{array}$ \\
\hline $\begin{array}{l}\text { Yes } \\
\text { No }\end{array}$ & $\begin{array}{r}3.9 \\
96.1\end{array}$ & $\begin{array}{l}48.9 \\
51.1\end{array}$ \\
\hline $\begin{array}{r}\text { Total } \% \\
\mathrm{~N}\end{array}$ & $\begin{array}{c}100.0 \\
280\end{array}$ & $\begin{array}{c}100.0 \\
133\end{array}$ \\
\hline
\end{tabular}

$\mathrm{X}^{2}=125.15,1$ d.f., $\mathrm{p}<.001$. 
Table 8.5 Distribution of respondents having informal personal relations with Sudanese by refugee category (urbanlrural)

\begin{tabular}{lcccc}
\hline & \multicolumn{2}{c}{ Organized settlements } & \multicolumn{2}{c}{ Spontaneous settlements } \\
\cline { 2 - 5 } Relations & Urban/ & & Urban// & \\
\hline Yes & Semi-Urban & Rural & Semi-Urban & Rural \\
No & 5.3 & 3.0 & 47.5 & 53.1 \\
\hline Total \% & 94.7 & 97.0 & 52.5 & 46.9 \\
\hline & 100.0 & 100.0 & 100.0 & 100.0 \\
\hline
\end{tabular}

Urban/Rural (organized) $\mathbf{X}^{2}=1.861$ d.f., not significant.

Urban/Rural (spontaneous) $\mathbf{X}^{2}=0.161$ d.f., not significant.

and inter-group communication. They foster contacts, comprehension and acceptance between the two communities. Hence, self-settlingrefugees, particularly urban refugees were more integrated than refugees in organized settlements. Although social communication is not intensive between refugees and Sudanese at any level, primary and secondary relations are more frequent when the former are living as a minority among the latter.

The spatial integration of refugees with the local people is supported by recent interest in integrating refugee aid into the general development efforts of the host country. This means that services that are created with international assistance will be used by refugees and Sudanese alike, thereby reducing the feelings of indignation and resentment among the local population and demonstrating that the presence of refugees can be an advantage. This helps not only in minimizing inter-communal tensions but facilitates the protection of refugees (Harrell-Bond, 1986:7).

Several problems were mentioned regarding spontaneous settlement of refugee among indigenous populations in Africa (UNHCR 1981). These problems are of a political and logistical nature and, it was argued, they could be minimized through organized settlements. Hence, a high proportion of the UNHCR budget for Africa was spent on such settlements (Harrell-Bond, 1986:9; Pitterman, 1983: 160-61), Following the overall trend in Africa the government of the Sudan has settled one-fifth of the refugees from Ethiopia in organized settlements and has plans to accommodate more in such schemes.

Spontaneous settlements as sources of tensions and conflicts. One of the arguments against spontaneous settlements is that they occur in border areas, giving rise to the possibilityof border tensions between the country of asylum and that of origin. It was assumed that such tensions can be minimized and the security of the refugees themselves guaranteed only if they are quartered in organized settlements far away from the borders (Documentation for the Khartoum Conference, Vol. II, 1980:3).

The other argument for spatial segregation is that refugees, particularly in urban settings, tend to concentrate in certain areas thereby creating pressures on resources and services. Such concentration tends, as is demonstrated by the relations between refugees and Sudanese, to create social conflict urban areas like Gedaref. It is believed that organized settlements are the best means to avoid such problems. However, there are also conflicts, although on a smaller scale, between the inhabi- 
tants of spatially segregated settlements and the local population. Our data indicate that spatial segregation is not necessarily the best solution to social tensions. Besides, as we shall see later, the organized and spatially segregated refugee communities are plagued by more unsettling social strife of an intra-group character than those that are spatially integrated in the host communities.

Logistical issues. A third argument against spontaneous refugee settlement among the local population is the logistical problem it entails. Unlike organized settlements, it is possible to reach refugees with assistance when they live scattered among the local population. It is not even easy to identify the numbers and the needs of such refugees (UNHCR, 1981:94). There is some truth in all of these arguments and both types of settlement have their advantages and disadvantages. However, refugees who have passed the relief stage, particularly those in the urban settings, seem to benefit more when they are spatially integrated in the host communities.

The empirical evidence presented and analyzed in this chapter so far indicates that spatial integration promotes interaction and social relations between refugees and Sudanese, and that spatial segregation in the form of organized settlements causes social isolation and is a hindrance to integration. In fact the advantages of organized settlements even in other ways are very limited. In spite of the services they offer, a large percentage of the respondents we interviewed seemed to be dissatisfied with their lives in the organized settlements. Refugees came or were brought to organized settlements in various ways, at different times and under different circumstances. Not all of them came to these places of their own free will.

Respondent opinions about organized settlements. Only about half of the respondents living in organized settlements considered them "suitable" places to live in. The other half considered the settlements as "unsuitable" places of abode. The corresponding figures for spontaneous settlements were 62 per cent "suitable" and 38 per cent "unsuitable". The findings indicate that refugees prefer spontaneous settlements and have negative attitudes towards organized settlements.

The reasons given by refugees for considering their places of residence "unsuitable" vary somewhat from settlement to settlement. The type of problems felt in spontaneous settlements differed markedly from those reported in the organized settlements. Lack of water and social problems were felt much more in the organized settlements than among self-settling refugee communities. At the time of our survey, the semi-urban settlement of Tawawa and the land settlement at Um Rakoba were experiencing a serious lack of water. The former lacked any water supply of its own and depended on tankers and donkey-carts which brought water from many kilometers away. In Tawawa, water expenses drew heavily on the subsistence economy of the refugee households. Um Rakoba relied on a single water-hole with a pump which often broke down leaving its inhabitants (more than five thousand people at that time) without water for days on end in the middle of the dry season.

Some of the organized settlements were seething with social problems and petty crimes such as drunkenness, theft, gambling and prostitution, which are created by their size and social structure, their artificial nature, the breakdown of social norms caused by anonymity, economic problems, frustration and the personal disorganization caused by life in exile.

Obviously organized settlements enjoy the advantages of services and facilities 
which self-settling refugees do not have. The spontaneous settlements lack health and educational facilities. In fact the inhabitants of organized settlements enjoy, in general, better health facilities than most of the local population and their children have a better chance of attending primary school than they had in their country of origin.

A child belonging to a family who have spontaneously settled among the local population has no such chance. It is often impossible to get a place in school as birth certificates are required for registration and refugees lack such documents. Remoteness or lack of communication with the urban centres also affects the spontaneous refugee settlements in the rural areas.

Although the "problem load" is somewhat heavier on refugees in the spontaneous settlements they are less dissatisfied than refugees in the organized settlements. In fact, some of the refugees who lived first in spontaneous urban settlements and live now in the organized settlements would prefer to return there because they feel they had better opportunities and better life there.

Consequently refugees "flee" the organized settlements in quite large numbers. About 18 per cent of the respondents said that since their arrival in the settlements one or more members of their households had re-emigrated. The rate of such migration from spontaneous settlements is slightly less, approximately 16 per cent. Re-emigration from other organized settlement sites is even higher than with our sample. According to a report compiled by Lars Jonsson (1982:5) on the wage earning settlements of Suki, 22 per cent of its initial inhabitants re-emigrated in a period of only one year. One of the consequences of such migration is a drastic change in the demographic structure of the settlements. Lars Jonsson noted that,

...the proportion of widows and singles became abnormally high in Suki due to the large migration. Overall, this group constituted 21.8 per cent of the households and an estimated

16.4 per cent of the total population in the three settlements (1982:6).

Thus the family composition, which has already been negatively affected by flight from the country of origin, is made more abnormal and less capable of integrating in the new environment as the strong elements migrate leaving behind women, children and old people.

\section{Intermarriage Between Refugees and Sudanese}

One important indicator of refugee-host social integration is the rate at which marriage occurs across the ethnic and cultural boundaries that divide them. Although it is very difficult to determine the direction of causation - for integration may promote intermarriage and vice-versa, or both influences may be interacting simultaneously - intermarriage is a sign of interaction, social proximity and of mutual acceptance between the two communities.

Intermarriage involves the contracting of persistent ties. Endogamy, on the other hand, presupposes some degree of isolation. When a marriage relation is contracted by a refugee or a migrant with a member of the host society, it often signifies the 
intention to become a more permanent inhabitant of the country of asylum or migration. Intermarriage denotes integration not only of a social character but also of a physical nature. Intermarriage is the only means by which a visible immigrant group can eventually merge into the host population and become totally assimilated.

Refugees from Ethiopia have lived in the Sudan for quite a long period of time. Some of our respondents have been there for more than a decade and, unless marriage is totally bounded, we would expect a certain rate of intermarriage with the indigenous families. In order to determine this, respondents were asked if they or members of their families were married to Sudanese. Only 9 of the interview households (2.2 per cent) answered this question in affirmative. Thus marriage relationships between refugees and Sudanese are neither open nor totally bounded. As we expected, intermarriage occurred at a very low rate.

The low rate of intermarriage between refugees and the indigenous people is partly explained by the lack of interaction that we have already discussed. According to our respondents there are also other factors, mainly economic and cultural, limiting the rate of intermarriage. Marriage is an expensive affair in the Sudan. It incurs enormous costs and the traditional "bride-price", feasts and presents to relatives entail expenses which a refugee household is unable to meet.

Even poor Sudanese men are unable to marry young because of these expenses. In fact marriage expenses are a cause for emigration from the Sudan and a significant percentage of Sudanese immigrants to the oil rich Gulf States give marriage as the main purpose of earning income abroad (ILO, 1984a:200).

The refugees and the northern Sudanese are tradition-bound and religious peoples. What is more, the two communities differ markedly on cultural and religious dimensions and these differences influence their marriage practices. The northern Sudanese are Orthodox Muslims while the majority of our respondents were Coptic Christians from the highlands of northern Ethiopia. Originating from rural Abyssinian communities the majority of these respondents have strong cultural and traditional ties which seem to have tightened even more since their flight. The refugees in some of the settlements were more zealous in their observation of religious practices than they seem to have been at home.

In general the religious barrier is quite strong and very few families are willing to break it through intermarriage. Even cultural and religious affiliations between asylum seekers and indigenous communities does not necessarily facilitate intermarriage. The Berta in Yabus and Muguf are Muslims, speak Arabic and even have co-ethnics in the Sudan. However, they told us that they were avoided by indigenous families as marriage partners not only because of their poverty but also because of their status as refugees.

It was also a common feeling among respondents from other sample sites that some of the local people were prejudiced against them simply because they were refugees. This attitude seems prevalent even on other levels because, as one observer pointed out, "once an individual becomes a refugee, it is as though he has become a member of another race, some other sub-human group" (cited in HarrellBond, 1986-155).

The practice of arranged marriage also limits the possiblitiesfor intermarriage. In the Sudan, as in most of the Muslim world, contracting a marriage is a family and clan affair. Among the criteria for contracting marriage relations, blood relation and aquaintance are important in the Islamic society of northern Sudan. Naturally this 
excludes the respondents, as most of them do not have kinship relations with their hosts.

Given these facts, significant rates of intermarriage between refugees and the Sudanese could not be expected. Hence marital relations cannot be expected to play any important role in social integration and assimilation for decades to come. In the case of permanent settlement the refugees here will, in general, remain distinct ethnic and cultural minorities (the refugee population is heterogenous) for a very long time, adding further complexity to the ethnic and cultural pluralism that characterizes the Sudan.

\section{Voluntary Organizations}

It is well known that voluntary associations are prevalent in urban Africa and are used by migrants who are separated from their kinsmen as a substitute for the extended family system which offered them social, economic and psychological security in the traditional rural environment (Little, 1965:24). Voluntary associations are not always the products of migration. Even non-migrant indigenous groups do form and belong to voluntary associations. However, their organizations often have rather narrow functions and serve specific needs (Radecki, 1979:11). It is not unusual that migrants and indigenous groups belong to different voluntary associations because it is often difficult, if not impossible, for newcomersof different ethnic, linguisticand cultural backgrounds to join the voluntary organizations of their hosts. What is more, migrants and refugees may find such organizations unsuitable for meeting their needs or even threatening to the identity which they aspire to preserve.

Immigrant, or "ethnic" voluntary organizations as they are often called, vary in their goals depending on the complexity of the socio-economicconditions which face them in the new environment. In general, immigrant voluntary organizations or associations serve as substitutes for the traditional social organizations such as the family and kinship groups that are abandoned due to uprooting. They cushion separation from families, friends and neighbours and alleviate the shock of a new and strange environment particularly among late arrivals. They provide a setting where immigants or refugees meet and establish ties. Thus voluntary organizations have an integrative function in immigrant communities. However, this is often limited to internal integration (internal to the immigrant community).

At the inter-community level, migrant voluntary association often have insular effects because they tend to preserve the immigrants' feeling of "distinct identity" and may thereby retard the rate of social integration and assimilation into the host society. Breton (1964:196) is of the opinion that "the presence of formal organizations in the ethnic community sets out forces that have the effect of keeping the social relations of immigrants within its boundaries".

\section{Voluntary organizations in sample sites}

About one-quarter of the heads of household interviewed in our study belonged to one or another sort of voluntary association. All of them belonged to associations which recruit their members only from among refugees. As is shown in Table 8.6, 
Table 8.6 Respondent membership of voluntary organizations by sample sites (\%)

\begin{tabular}{|c|c|c|c|c|c|c|c|}
\hline $\begin{array}{l}\text { Member- } \\
\text { ship }\end{array}$ & Gedaref & Tawawa & $\begin{array}{l}\text { Um } \\
\text { Gulja }\end{array}$ & $\begin{array}{l}\text { Um } \\
\text { Rakoba }\end{array}$ & $\begin{array}{l}\text { Damazin } \\
\text { Kurmuk }\end{array}$ & $\begin{array}{l}\text { Yabus } \\
\text { Muguff }\end{array}$ & Total \\
\hline $\begin{array}{l}\text { Yes } \\
\text { No }\end{array}$ & $\begin{array}{l}27.5 \\
72.5\end{array}$ & $\begin{array}{r}5.3 \\
94.7\end{array}$ & $\begin{array}{r}9.3 \\
90.7\end{array}$ & $\begin{array}{l}37.1 \\
62.9\end{array}$ & $\begin{array}{l}50.0 \\
50.0\end{array}$ & $\begin{array}{l}56.3 \\
43.7\end{array}$ & $\begin{array}{l}24.2 \\
75.8\end{array}$ \\
\hline $\begin{array}{c}\text { Total } \% \\
\mathrm{~N}\end{array}$ & $\begin{array}{c}100.0 \\
69\end{array}$ & $\begin{array}{c}100.0 \\
113\end{array}$ & $\begin{array}{c}100.0 \\
97\end{array}$ & $\begin{array}{c}100.0 \\
70\end{array}$ & $\begin{array}{c}100.0 \\
32\end{array}$ & $\begin{array}{c}100.0 \\
32\end{array}$ & $\begin{array}{c}100.0 \\
413\end{array}$ \\
\hline
\end{tabular}

voluntary associations existed in all types of settlements and recruited members from all categories of refugees. However, membership among respondents varied significantly from one site to another. Thus, 56.3 per cent of households interviewed in the rural spontaneous settlements of Yabus and Muguf, 68.8 per cent in the towns of Damazin and Kurmuk, 37.1 per cent in the organized land settlement of Um Rakoba, 27.5 per cent in the town of Gedaref, 9.3 per cent in the rural wage earning organized settlement of Um Gulja and only 5.3 per cent in the organized semi-urban settlement of Tawawa were members of voluntary organizations.

Refugee voluntary associations are organized on various levels. The activities of some are limited to a settlement, a town or a section of a city. There are also associations with complex organizational structures, having branches and affiliations not only in the Sudan but also in other parts of the world. Such associations are multi-functional and of a permanent nature. The majority of the associations recruit their members from a single refugee ethnic group. Thus, there are Oromo, Eritrean, etc., voluntary associations. In the organized settlements membership is often multi-national or multi-ethnic.

\section{Types and functions of voluntary associations}

As indicated in Table 8.7 four main types of associations were identified among those to which the respondents belonged. They are categorized according to their declared objectives as social/cultural, religious, political and economic. However, most of the associations fulfil more than one role, declared or undeclared. The bigger associations have a multitude of functions which include such areas as welfare, education, health, politics etc., and have quite complex organizational structures.

The associations are not entirely the products of exile. They are rooted in traditional forms of social organizations like eder, equb, dabo, mahber, sanbate, etc., which are prevalent in all parts of Ethiopia and to which 37 per cent of the respondent belonged before their flight. However, the set of functions of each type of association differs markedly from those in the country of origin. In most cases the original models were modified to include new functions in order to meet the exigencies of life in exile.

As mentioned, it is often one function or objective which is declared and emphasized for each association. But their members seem to get various other benefits from them. Thus when we asked the respondents how their associations benefited them, they mentioned more than one way in which they were rewarded. While the declared objective of an association may be religious, its functions do not stop at fulfulling the spiritual needs of its members. It provides them with security; mainly psychological 
Table 8.7 Membership of voluntary organizations by type of organization (\%)

\begin{tabular}{llll}
\hline $\begin{array}{l}\text { Type of voluntary } \\
\text { organization }\end{array}$ & $\begin{array}{l}\text { Organized } \\
\text { settlement }\end{array}$ & $\begin{array}{l}\text { Spontaneous } \\
\text { settlement }\end{array}$ & Total \\
\hline Religious/cultural & 48.8 & 13.7 & 29.8 \\
Political & 52.2 & 47.1 & 48.9 \\
Economic & 0.0 & 92.2 & 50.0 \\
\hline \multicolumn{1}{c}{$\mathrm{N}$} & 41 & 59 & 100 \\
\hline
\end{tabular}

but often even physical. Members with economic problems were helped out by the other members of the association. Maintenance of national and cultural identity were 'benefits' which respondents often claimed to have gained from their associations. In the urban areas, voluntary associations enabled individual refugees to reduce isolation in the foreign environment.

The larger associations are 'national' in character and run under such names as the Oromo Relief Association (ORA), the Relief Society of Tigray (REST) and the Eritrean Relief Association (ERA). These national association are somewhat peculiar among voluntary associations. They have members but their servicesare more or less altruistic and mostly directed towards non-members. They are multi-functional organizations established and run by refugees for refugees and displaced peoples. They operate in the Sudan where they have their head offices and inside their regions of origin - Oromia, Tigray and Eritrea. They cooperate with the various national liberation fronts in these areas and provide a number of essential services such as medication, education, welfare and agricultural extension to displaced persons and communities in the areas controlled by liberation movements.

The scope of their functions is as wide among the refugee communities. ORA has run food, medical and literacy programmes for Oromo and Berta refugees in the Blue Nile province since 1979. Without the service of this organization, many refugees who lack any access to international assistance would have found it difficult to survive the initial periods of flight and the consecutive droughts. REST operates in a number of Sudanese towns and runs self-help associations, literacy classes, kindergartens and workshops for Tigrayan refugees.

In the Sudan and elsewhere there are also political and semi-politicalassociations organized and run by refugees. In almost every city, town and even in settlements in eastern Sudan there are women's, workers' and students' associations which are engaged in social, political and cultural activities. Most of them are affiliates of the liberation fronts or the national relief associations and are directly or indirectly involved in the affairs of the refugee communities and the political struggles inside the country of origin. Moreover, they are also engaged in improving the conditions of their members. The activities of the Oromo chaya ummata or voluntary associations of Oromo refugees affiliated to ORA can be cited as an example.

The chaya ummata seeks primarily to find homes for people, although it has other functions. At meetings, which takes place every Friday, its members are informed about political events which are relevant to their situation: they discuss social problems and literacy campaigns in the Oromo language (using the Latin Script) which are regularly held in the office of the ORA. People are aware of the stimulating value of such campaigns in strengthening ethnic consciousness and solidarity. A particular function resulting from the 
Table 8.8 Membership of voluntary organizations by type of settlement

\begin{tabular}{|c|c|c|c|}
\hline $\begin{array}{l}\text { Member- } \\
\text { ship }\end{array}$ & $\begin{array}{l}\text { Spontaneous } \\
\text { settlement }\end{array}$ & $\begin{array}{l}\text { Organized } \\
\text { settlement }\end{array}$ & Total \\
\hline $\begin{array}{l}\text { Yes } \\
\text { No }\end{array}$ & $\begin{array}{l}44.4 \\
55.6 \\
\end{array}$ & $\begin{array}{l}14.6 \\
85.4\end{array}$ & $\begin{array}{l}24.2 \\
75.8 \\
\end{array}$ \\
\hline $\begin{array}{c}\text { Total } \% \\
\mathrm{~N}\end{array}$ & $\begin{array}{c}100.0 \\
133\end{array}$ & $\begin{array}{c}100.0 \\
280\end{array}$ & $\begin{array}{c}100.0 \\
430\end{array}$ \\
\hline
\end{tabular}

$\mathrm{X}^{2}=44.16,1$ d.f., $\mathrm{p}<.001$.

exile situation is the support which the organization offers its members in their dealings with the Sudanese bureaucracy, for instance, in obtaining identity cards for refugees (Braukämper, 1982-83:11).

Economic self-reliance and solidarity among its members is an important objective of the chaya ummata. Dr. Braukamper continues,

Because the chaya ummata receives monthly fees from its members and thus possesses a budget, it is also able to serve as a kind of social insurance institution. It supports people who are deprived of their income through accidents, assumes responsibility for funeral ceremonies and also lends small amounts of money to those, who, for example, want to buy a donkey for carrying water (ibid.).

Although it is only about a quarter of the refugees who are involved in associational membership or activities, the existence of voluntary associations by itself is an implication of the dynamism of their community in meeting the conditions of exile. It indicates the internal integration of some sections of the refugee community and the solidarity that exists between their members. Apathy, powerlessness and social and economic marginality may characterize the refugee population at large. However, the existence of voluntary associations can be taken as an indication that refugee communities are 'not always pathological and hopelessly disorganized, as often described by journalists. Solidarity, self-help and organization are concepts which are not alien to a significant part of the refugee community even in an African setting.

Rates of membership varied significantly according to the type of settlement. As is indicated in Table 8.8, about 44 per cent of the self-settling respondents and only about 15 per cent of those accommodated in organized settlements were members of voluntary organizations at the time of the survey. These differences between the two patterns of settlement could be due to various factors.

One such factor may be the effect of humanitarian aid on normative social behaviour. When a community is faced with a problem the normal reaction of its members is to try and find solutions to it either individually or collectively, depending upon the magnitude of the problem.

The collective effort which is mobilized when problems faced are beyond individual capacity often occurs within the framework of existing social organizations and institutions, or those that are created in order to meet the exigencies of new situations. Immigrant voluntary organizations function to meet the demands of a new social, economic and political environment and are indicators of solidarity and self-reliance in the immigrant communities. 
Humanitarian aid often tends to discourage refugees from organizing themselves and becoming cohesive communities with their own leadership. It is not aid per se that constitutes the obstacle to development of social organizations but rather the approach of humanitarian agencies in its administration. Day-Thompson (1984:5) has suggested that the refugee on his arrival in the host-society is almost reduced to the level of a new-born baby and might need care, often total care. But like the baby that grows, the refugee also gravitates towards self-reliance unless someone surrounds him with a programme that keeps him dependent. Although the policy of the UNHCR and the major voluntary agencies is to assist refugees to become selfreliant, what happens in practice is sometimes the opposite. The attitude and approach of the aid agencies and their staff is often patronizing and contradicts their policies. Refugees are rarely encouraged to get organized and solve their own problems. At the time our field, survey, refugee organizations received minimal assistance or encouragement from the major relief organizations including the UNHCR.

Participation is a common theme of conferences, workshops and writings that deal with refugee aid. Participation implies here the effective involvement of the poor in decision making, letting them have power and control over their own lives and affairs. This does not seem to be the case among the assisted refugees sheltered in organized settlements. In the three organized settlements covered by this study, the inhabitants were only marginally involved in affairs that concerned their communities. Although there were elected committees in all the three sites their roles, according to members, were limited to minor duties like settling disputes among the inhabitants and reporting problems to the authorities. They were excluded from the more important decisions regarding the administration of their settlement. Assistance is given and projects are implemented on conditions which the humanitarian organizations and the host government prescribe. Little attention is paid to the wishes and views of the recipients. Barbara Harrell-Bond (1986:67) has indicated that the ideology of aid agencies towards African refugees is generally anti-participatory. Instead of involving the needy in the solutions of their problems, aid agencies impose their solutions on them. This approach is generally negative because it strips the community of its own resources and breaks down its institutions. The aid recipients are made not only materially dependent but lose capacity to organize and mobilize their resources to help themselves. We are not implying that aid is not needed by refugees. The point is that aid should enhance the development of the recipients' own resources and capacities and should not promote unproductive and dependent attitudes.

It has been suggested that the social behaviour generally known as the 'dependency syndrome' and noted among refugees results from this type of humanitarian aid (Harrell-Bond, 1986: 300-301). Apparent lack of effort towards self-reliance lack of cooperation and solidarity with fellow camp or settlement dwellers and a low level of social cohesion and organization are symptoms of the dependency syndrome. Our findings indicate that solidarity and self-help efforts were more prevalent among unaided and self-settling respondents than among those who live in organized schemes supported by international organizations. Mutual mistrust, conflicts and other indicators of a lack of cohesion were more prevalent in organized settlements than in spontaneous settings.

We should, however, point out that membership in voluntary organizations is not 
uniformly low in all organized settlements. There were significant differences among organized settlements depending upon the major means of livelihood of their inhabitants. Our findings indicate that more than one third of the respondents in organized land settlement (farmers) and less than one-tenth of the respondents from wage earning settlements were members of voluntary organizations.

The main reason which respondents and elders gave for the lack of social cohesion and organization in wage-earning schemes was the constant absence of inhabitants from the settlements while working or looking for work elsewhere. For respondents who did not have families, the sole link to the wage settlement was their straw hut to which they returned now and then during slack seasons and unemployment. This created a sense of "temporariness" which discouraged the inhabitants from entering into obligations which required their regular presence in the settlement.

Because of the constant mobility in and out of the settlements, inhabitants of wage-earning schemes remain strangers. According to members of the elders' committee in Tawawa, this situation had also created mistrust and a lack of solidarity among dwellers in the settlement. There are also other factors which make organized wage-earning settlements the least viable strategy for the adjustment and integration of refugees.

As we have repeatedly indicated, almost every household interviewed was affected by family disintegration as the result of uprooting. Family members were either left behind, died or disappeared without any trace in the process of flight. The households were incomplete. Agricultural wage-employment tends to exacerbate family disintegration by scattering the remaining members of the household. Except in areas where the settlements were located near agricultural schemes, refugees have to travel far to find employment. And because of the lack of transportation, it is almost impossible for farm labourers to visit their families frequently. Consequently, most of the male heads of household stay away from their families and settlement for three to four months at a time.

Under normal conditions such absences would not have caused much of a problem. But for households which have lost the support of the extended household system and live socially isolated in a foreign environment, the absence of the head of the family is very difficult for psychological and practical (security) reasons. As mentioned before, the economic problems which are caused by the seasonal nature of agricultural wage-employment have resulted in high rates of out-migration from organized wage-earning settlements. Such out-migration has drastic effects on the demographic structure because it is the strong and those with leadership capacities who leave and the weak: women, children, widows, old people etc., who are left behind.

In general, wage-earning settlements constitute collections of individuals and incomplete households. The conditions prevailinghere provide only minimal possiblities for the development of social organizations and the sense of community.

\section{Social Conflicts and Integration}

All human relations involve integrative and conflictual processes. There is no consensus among sociologists on a specific definition of social conflict. Conflict 
theorists like Lewis Coser (1956) and Ralf Dahrendorf (1958) recognize the pervasiveness of social conflict and employ broad definitions. Hence, hostilities like war, competition, antagonism, tension, contradictions, quarrels, violence, opposition, disputes, etc., are invariably treated as aspects of conflict in sociological discourse. In short, conflict is considered as "any social situation or process in which two or more entities are linked by at least one form of antagonistic interaction" (Fink, cited in Turner, 1978:183).

Sociologists isolate various units and levels between and within which social conflict occurs. Ralf Dahrendorf speaks of conflict between roles, groups, sectors, societies and supra-societal units (ibid., p. 181). Sociological research and theory on conflict are also prominent in a large number of specific areas like international, racial, class, religious, gender, community and occupational conflicts to name just a few. Our focus in this section is mainly on two types of conflicts: inter-community and intra-community, i.e., conflict between the local and refugee-communities, and conflict within refugee communities.

Interaction between antagonists is a pre-requisite for conflict. However, conflict arises not from the interaction as such but from some incompatibility between the interacting social units. Such incompatibility has various sources. Competition over scarce resources or inequality in the distribution of such resources, unreciprocity or incongruity over values, stress and frustration are some of the possible sources of conflict (Ilfield and Metzner, 1970:130).

As conflict is inherent in all human relations, the cause of social conflicts are as variegated as human relations themselves. Whatever their manifest causes may be it is possible to consider conflicts as having an objective and a subjective basis. Objective conflicts arise when individuals or groups clash on claims to scarce resources, territory, power, social status or over ideologies and values.

Objective conflicts are realistic since they are sparked by contention over tangible objects or issues. Subjective conflicts arise from aggressive impulses, and irrational resentment and hatred often directed against outsiders and ethnic or racial minorities. Scapegoating is a good example of such a dispositon. Subjective conflict lacks a material basis (Ilfield and Metzner, 1970:130-31).

Conflict resolution is conceived as an aspect of integration. Here conflict resolution is mainly regarded in terms of adjustment and accommodation between antagonists and not in terms of the victory of one unit, group or class over another. The assumption suggests a dialectical relationship between conflict and integration. Ali Mazrui pointed out the role of conflict in the integration of plural societies in Africa in the following words:

Where conflict plays a crucial part is in moving from a relationship of contact to a relationship of compromise, and then from compromise to coalescence. It is the cumulative experience of conflict resolution which deepens the degree of integration in a given society $(1969: 335)$.

\section{Conflict in the Refugee Situation}

The refugee problem is more than the flight of people from one country to another. It involves changes in the distribution of scarce resources and services of the host 
Table 8.9 Distribution of respondents reporting host-refugee conflicts by sample sites (\%)

\begin{tabular}{|c|c|c|c|c|c|c|c|}
\hline Conflict & Gedaref & Tawawa & $\begin{array}{l}\text { Urn } \\
\text { Gulja }\end{array}$ & $\begin{array}{l}\text { Urn } \\
\text { Rakoba }\end{array}$ & $\begin{array}{l}\text { Damazin } \\
\text { Kurrnuk }\end{array}$ & $\begin{array}{l}\text { Yabus } \\
\text { Muguf }\end{array}$ & Total \\
\hline Yes & 36.2 & 20.6 & 7.2 & 12.9 & 21.9 & 0.0 & 28.3 \\
\hline No & 63.8 & 79.4 & 92.8 & 87.1 & 78.1 & 100.0 & 71.7 \\
\hline $\begin{array}{r}\text { Total } \% \\
\mathrm{~N}\end{array}$ & $\begin{array}{c}100.0 \\
69\end{array}$ & $\begin{array}{c}100.0 \\
113\end{array}$ & $\begin{array}{c}100.0 \\
97\end{array}$ & $\begin{array}{c}100.0 \\
90\end{array}$ & $\begin{array}{c}100.0 \\
32\end{array}$ & $\begin{array}{c}100.0 \\
32\end{array}$ & $\begin{array}{c}100.0 \\
413\end{array}$ \\
\hline
\end{tabular}

country. Such a change in resource-distribution entails conflicts between the refugees who aspire to get as large portion of the resources as possible in order to satisfy their basic needs, and the local population who naturally want to withhold as much as possible in order to maintain their standard of living. Moreover, refugee influxes entail, for both the exiles and their hosts, confrontation with new norms and alien social values to which they have to adjust. Adjustment to this novel and often complex situation cannot always be attained peacefully but may involve conflict.

We asked respondents whether they had been involved in or had witnessed conflicts between refugees and the local population in their communities. About 28 per cent replied that they had witnessed open conflicts between refugees and their hosts or that they themselves had been involved in them at one time or another. These conflicts had been mainly petty quarrels. They were often expressed verbally but weapons like clubs and knives had also been used. According to the majority of these respondents the conflicts had involved more than two persons. However, it was only on few occasions that such conflicts had become wide or violent enough to pose a real danger to general security.

Conflicts occur in nearly all types of settlements. However, the results of our survey indicate (Table 8.10a) that spontaneous settlements were afflicted by these conflicts more frequently than organized settlements. But there were even differences among the spontaneous settlements. Conflicts were most frequent in Gedaref, while the self-settling refugees in the rural areas of the Blue Nile Province seemed to be conflict-free.

Several factors account for the absence of social conflict between the refugees and the local population in the rural areas of the Blue Nile Province. The refugee ratio in the population is very low here compared with, for example, that in the Kassala Province. The refugee communities are small and scattered over a wide area, so that their presence is not felt much by the local population. What is more important, competition over resources, the main cause of conflict is relatively limited here. Farmlands and pastures, the two resources which refugees share with the local population, are quite abundant, while social services are non-existent.

It is not the type but the location of refugee settlements which influences the frequency of conflict. The varying frequency of social interaction in the different environments accounts for the differential rates of conflict. Refugees in the urban environments have more contact with their neighbours than those in the rural settings. In rural areas, particularly in the organized settlements, the relationship between refugees and the local population is not much more than coexistence. A relationship of bare coexistence has little conflict potential. 
Table 8.10a Host-refugee conflicts by type of settlement (\%)

\begin{tabular}{|c|c|c|c|}
\hline Conflict & $\begin{array}{l}\text { Organized } \\
\text { settlement }\end{array}$ & $\begin{array}{l}\text { Spontaneous } \\
\text { settlement }\end{array}$ & Total \\
\hline $\begin{array}{l}\text { Yes } \\
\text { No } \\
\end{array}$ & $\begin{array}{l}20.7 \\
79.3 \\
\end{array}$ & $\begin{array}{l}40.6 \\
59.4 \\
\end{array}$ & $\begin{array}{l}28.3 \\
71.7 \\
\end{array}$ \\
\hline $\begin{array}{r}\text { Total } \% \\
\mathrm{~N} \\
\end{array}$ & $\begin{array}{c}100.0 \\
280\end{array}$ & $\begin{array}{c}100.0 \\
133\end{array}$ & $\begin{array}{c}100.0 \\
413\end{array}$ \\
\hline
\end{tabular}

$\mathrm{X}^{2}=18.19,1$ d.f., $\mathrm{p}<.001$.

Table $8.10 \mathrm{~b}$ Host-refugee conflicts by refugee category (\%)

\begin{tabular}{lccc}
\hline Conflict & Urban/Semi-urban & Rural & Total \\
\hline Yes & 43.0 & 10.0 & 28.3 \\
No & 57.0 & & \\
90.0 & 71,7 & 100.0 & 100.0 \\
\hline Total \% & 100.0 & 199 & 413 \\
\hline & 214 & & \\
\hline
\end{tabular}

$\mathrm{X}^{2}=56.7,1$ d.f., $\mathrm{p}<.001$.

Causes of refugee-Sudanese conflicts

The conflicts which are said to exist between Sudanese and refugees have both objective and subjective elements in their origins. However, the objective elements outweigh the subjective elements by far because, according to our respondents, the major source of conflict between refugees and their host was economicfactors as well as incompatibility in cultural and religious spheres.

The economic factor in host-refugee conflicts

Both the respondents and independent observers agree that the refugees are blamed for causing economic shortages in the Sudan. Some of the respondents told us that they had been openly blamed by the local population for causing shortages in services and commodities and the rapid rise in prices.

We have already indicated the strains and burdens imposed upon the fragile economy and infrustracture of the Sudan by the large influx of refugees into the country. The burden is felt most by the poorer section of the Sudanese society for a number of reasons.

In times of food shortage, refugees deplete local food supplies and drive up food prices making it more difficult for wage labourers to subsist on their incomes. This has been the situation in the Sudan particularly during the last three years of scarcity caused by the Sahel drought. The contrary can occur when food aid is given to refugees who sell it at lower prices to obtain basic necessities. This forces food prices down causing the rural poor to get less for their small surpluses. Either way, large influxes of refugees such as in the eastern Sudan are likely to have an adverse effect upon the economy of the hosts and resentment is the natural result (Chambers, 1984: 6-8). 
The conditions created by mass influxes are also often exploited by the richer section of the host society to drive down wages or to demand higher rents. Thus, the abundance of cheap refugee-labour has obvious negative consequences for poor locals who subsist by selling their labour. In the Sudan, where the law regulating the minimum wage is not particularly respected, the local labour force is priced out of the labour market in two ways by the presence of refugees. Since refugees do not belong to labour unions, their bargaining position with employers is weak and they are forced to accept what they are offered (ILO, 1983a: 63-67). Secondly, refugees living in rural settlements are at one time or another subsidized by international aid. During such times they can afford to take lower wages. This has serious repurcussions on the local poor whose incomes are already under the existence minimum and cannot afford to take still lower wages.

Refugee influx also has an impact on the rent markets particularly in the slum areas of Sudanese towns. In Gedaref, according to our informants, house rents rose by about 400 per cent between 1978 and 1983 . The tukuls in which about 90 per cent of the respondents live in this city were rented for an average of five-six Sudanese pounds a month in the middle of the 1970s. In 1983 the respondents paid about $£ 20$ a month for the same tukuls. This rapid increase, which seems to have most affected the shanty towns and poor quarters, is attributed to the large influx of refugees into Gedaref and its surroundings. Although there are indications that refugees pay higher rents than the Sudanese (Post, 1983b:9) the higher demand created by the influx certainly results in increased rents even for the local population (cf. Weaver, 1985:154).

Robert Chambers (1984:14) pointed out that conflict between refugees and locals over resources like pastures, fishing waters, forests and wild animals held as communal property is common. Because of the lack of alternatives, refugees often eke out their livelihoods from resources which the poor locals also use as sources of supplementary income.

When a refugee influx is massive, such resources are quickly depleted. In the Sudan, where a significant per cent of refugees earn their livelihood selling fire-wood and charcoal, and where tens of thousands of tukuls have been built to shelter them, large areas of forest have been cut down. This causes a scarcity of building materials and fuel for cooking. It is particularly the case in the Gedaref area where there are two large organized settlements (Tawawa and Um Gulja) and thousands of selfsettling refugees. The depletion of forest resources affects primarily the poor who cannot afford to pay for fuel and are forced to travel long distances to collect firewood and building materials.

Conflicts also arise as a result of misdirected discontent and anger. Scapegoating is a common sociological phenomenon and in times of political, economic and social crises it is often minority groups who are blamed for the misfortunes of society. Immigrants and refugees often become scapegoats. Ahmed Karadawi (1983:539), himself Sudanese and Assistant Commissioner for Refugees, wrote that refugees have often been portrayed wrongly as sources of political, economic and social problems during times of crisis and subsequently evicted from the urban areas to rural settlements. In 1982-83 the chronic water shortage in Gedaref was blamed by the indigenous people on the refugees although the problem mainly arose from technical problems in the distribution system.

Aid from international humanitarian agencies to refugees in a situation where the 
majority of the hosts are as needy may create jealousies and conflicts. Although we did not observe this in the Sudan, there is the possibility that the local population, particularly the poorer section, might feel that the refugees are unduly favoured. Unless assistance takes into consideration the needs of the poor hosts and contributes towards the development of the whole community there is the danger that they may attribute their misery to the presence of refugees and consequently feel and act hostile towards them, thereby blocking their integration into Sudanese society.

\section{Social-cultural factors}

The other source of refugee-Sudanese conflict is social and cultural incompatibility between the two groups. As mentioned before, the majority of the refugees in eastern Sudan are Christians of the Coptic denomination whereas their hosts are Muslims. Naturally this gives cause for some degree of incompatibility regarding basic values. Although there seems to be no open conflict on religious grounds as such, there is obvious resentment and avoidance in some areas not only between refugees and their hosts but even between Christian and Muslim refugees.

In addition to the religious difference, and partly because of it, most refugees tend to have conflicting views with their hosts over issues like the use of alcohol and the role of women in society. As was mentioned earlier, the role of women is a major area of cultural and behavioural conflict between the two communities. Refugee women are not only heads of households but many of them also work outside the home, thus committing an act that many Sudanese do not appreciate. Furthermore, many female refugees are self-employed, selling food and alcoholicdrinks. Brewing and selling alcoholic drinks is illegal in the Sudan. It also sinful according to the religious tenets of the northern Sudanese society. Since the sale of alcoholic drinks was combined with prostitution by some of the women, the refugee group to which they belonged was regarded by the more conservative circles in the Sudan as a negative quality in the cultural and moral sense.

The refugee and Sudanese women differ in matters of dressing. Northern Sudanese women clothe in their traditional taub, a sari-like garment which covers all of their body except the face, whereas refugee women dress more freely. What is more, Sudanese women are said to have been influenced by the style of refugee women in the urban areas. The Sudan, like the rest of the Muslim world, is experiencing a growing religious fundamentalism, and the style of the refugee women tends to create resentment among some hosts.

The conflicts between refugees and Sudanese are often expressed openly but they seldom reach a level of wide-spread violence. They do affect refugee integration into the host society in certain ways. But the overall relationship between the two communities should not be characterized as generally hostile. In general, the attitude of the Sudanese public towards refugees is not only friendly but also sympathetic and accommodating. The hospitality and solidarity which the people of the Sudan have shown towards exiles, in spite of the huge influx and the economic catastrophe in which their country finds itself, is what strikes one most while travelling in that country. The type of xenophobia which refugees in Europe experience is unknown in the Sudan. 
Table 8.11 Respondents reporting refugee-refugee conflicts by sample sites (\%)

\begin{tabular}{|c|c|c|c|c|c|c|c|}
\hline \multicolumn{2}{|c|}{$\begin{array}{l}\text { Conflict } \\
\text { experience Gedaref }\end{array}$} & Tawawa & $\begin{array}{l}\text { Urn } \\
\text { Gulja }\end{array}$ & $\begin{array}{l}\text { Urn } \\
\text { Rakoba }\end{array}$ & $\begin{array}{l}\text { Damazin } \\
\text { Kurmuk }\end{array}$ & $\begin{array}{l}\text { Yabus } \\
\text { Muguf }\end{array}$ & Total \\
\hline $\begin{array}{l}\text { Yes } \\
\text { No }\end{array}$ & $\begin{array}{l}56.5 \\
26.5\end{array}$ & $\begin{array}{l}73.5 \\
26.5\end{array}$ & $\begin{array}{l}64.9 \\
35.1\end{array}$ & $\begin{array}{l}32.9 \\
67.1\end{array}$ & $\begin{array}{l}15.6 \\
84.4\end{array}$ & $\begin{array}{r}0.0 \\
100.0\end{array}$ & $\begin{array}{l}51.6 \\
48.4\end{array}$ \\
\hline $\begin{array}{c}\text { Total } \% \\
\mathrm{~N}\end{array}$ & $\begin{array}{c}100.0 \\
69\end{array}$ & $\begin{array}{c}100.0 \\
113\end{array}$ & $\begin{array}{l}100.0 \\
97\end{array}$ & $\begin{array}{l}100.0 \\
70\end{array}$ & $\begin{array}{l}100.0 \\
32\end{array}$ & $\begin{array}{l}100.0 \\
32\end{array}$ & $\begin{array}{c}100.0 \\
413\end{array}$ \\
\hline
\end{tabular}

\section{Conflict among refugees}

Refugee internal social relations are also characterized by conflicts and antagonism that have some bearings on refugee adjustment and integration in the country of asylum. According to our findings, social conflicts occur more frequently among refugees themselves than between refugees and Sudanese. About half $(\mathrm{N}=213)$ of our respondents said that they had been either involved in or had witnessed open conflict between their fellow refugees.

The factors behind the conflicts among refugees are structural as well as social and psychological. Some are similar to those that cause conflicts between refugees and Sudanese. Table 8.12 summarizes the answers given by our respondents regarding the causes of antagonism within refugee communities.

As was explained in Chapter 3 the question of nationalities is a fundamental cause of the armed struggle taking place in Ethiopia. This conflict has crossed borders and followed refugees into exile, and manifests itself in interpersonal and intergroup animosities.

Some degree of inter-group animosity due to religious differences is common in parts of Ethiopia. However, such animosities are seldom expressed in open violence. The same situation is reflected in some refugee communities, particularly in the settlement of Um Rakoba, where we observed obvious tensions and avoidance between the Muslim minority and Christian majority.

Among the structural causes, political factors constitute a major source of social conflict among refugees. Almost every spectrum of the Ethiopian political scene is reflected in the refugee communities in the Sudan. Major national liberation fronts like the EPLF and OLF as well as smaller groups and political factions all have their followers among the refugee population.

The relations between the supporters of some of these liberation fronts and political factions are not always free of conflict. As shown in Table 8.12, 47.9 per cent

Table 8.12 Respondents reporting conflicts among refugees by cause of conflicts (\%)

\begin{tabular}{lr}
\hline Causes & $\%$ \\
\hline 'Ethnic' differences & 16.4 \\
Religious differences & 3.3 \\
Political issues & 47.9 \\
Frustration & 5.6 \\
Idleness, drinking, etc. & 52.1 \\
\hline \multicolumn{1}{c}{$\mathrm{N}$} & 213 \\
\hline
\end{tabular}


of the conflicts reported originated in political differences. These conflicts were sometimes quite violent and caused substantial material damage. One such incident in Um Gulja in 1982 resulted in the loss of several lives. The major cause of conflict among refugees was the exile situation itself, in its social and psychological effects. According to our informants, frustration causes personal and interpersonal conflicts. Idleness and drinking, phenomena that are attendant on exile, were said to lead to the majority of conflict situations. Idleness, frustration and alcoholism are common phenomena because unemployment and underemployment characterize many of the refugee communities. Alcoholism often comes into the picture because, as the elders in Tawawa and Um Gulja put it, some people spend whatever they earn on drinking in order to dull their disappointment, humiliation and frustration.

Conflict among refugees is felt more in organized settlements than in self-settling communities. According to our data summarized in Table 8.13, nearly twice as many respondents from the organized settlements as from the self-settling group had experienced interpersonal and intergroup conflicts.

Several factors seem to account for the reported differences in the rate of conflict occurrence in the two settings. The demographical structure of the organized settlements is an important contributory factor to social strife. Many of the organized settlements have an abnormal demographic structure. In some, women and children constitute the majority. In others like Tawawa young men are in the clear majority. Even among the female population, a large proportion are young and without both family and marital protection. Abscence of the traditional source of authority (family, elders) and social control, allows anti-social behaviour and conflict in the organized settlements. Some of these settlements shelter people with limited interpersonal and intergroup relations. As we have noted before, the sense of community is not yet developed and voluntary associations are nearly absent in settlement like Tawawa and Um Gulja. In short, there was very weak internal social integration and cohesion among the inhabitants of the organized settlements studied.

On the contrary, the self-settling refugees lived in "normal" communities among the local population. Lack of normlessness and anti-social behaviour may not be as prevalent among them as they are obliged to observe some of the norms of the host society like their Sudanese neighbours. This is not the case with those living in segregated and isolated settlements. Besides it seems that the "we" feeling is more developed among self-settling respondents and intra-group unity and solidarity against "outsiders" seems to minimize conflict amongst them. As we have already indicated, conflict between the refugees and their hosts occur more often in spontaneous than in organized settlements.

Table 8.13 Respondents reporting conflict among refugees by type of settlement (\%)

\begin{tabular}{|c|c|c|}
\hline $\begin{array}{l}\text { Conflict } \\
\text { experience }\end{array}$ & $\begin{array}{l}\text { Spontaneous } \\
\text { settlements }\end{array}$ & $\begin{array}{l}\text { Organized } \\
\text { settlements }\end{array}$ \\
\hline $\begin{array}{l}\text { Yes } \\
\text { No }\end{array}$ & $\begin{array}{l}33.1 \\
66.9\end{array}$ & $\begin{array}{l}60.4 \\
39.6\end{array}$ \\
\hline $\begin{array}{r}\text { Total } \% \\
\mathrm{~N}\end{array}$ & $\begin{array}{c}100.0 \\
133\end{array}$ & $\begin{array}{c}100.0 \\
280\end{array}$ \\
\hline
\end{tabular}

$\mathrm{X}^{2}=27.77,1$ d.f., $\mathrm{p}<.001$. 


\section{Summary}

An attempt was made in this chapter to examine the process of refugee integration in the host society. Variables such as social interaction, friendship formation, knowledge of Arabic, intermarriage, membership in voluntary organizations and social conflict were considered as its indicators. Our findings show that integration was quite low according to most of these indices.

Interaction between the local people and refugees, particularly those in the organized settlements, was very limited. Few of the respondents had managed to establish close contacts and friendship with members of the host community. Several factors seem to determine social interaction in this connection. One such factor is the knowledge of Arabic, the lingua franca of northern Sudan. Only a minority of the respondents spoke functional Arabic. While interaction, even at the informal level is quite frequent between those who speak "good" Arabic, the majority of the respondents were unable to establish meaningful contacts with their hosts because of lack of Arabic. This problem is exacerbated by the unavailability of language training opportunities for refugees in the Sudan.

The type of settlement is another important variable which tends to associate with different aspects of social integration and with social interaction and informal relations between refugees and the Sudanese. Consequently only about 4 per cent of the respondents from the organized settlements compared with 49 per cent of the spontaneously settled said that they had informal relationships with members of the local community. The spatial factor also had a significant effect upon language learning since only 48 per cent of the respondents living in organized settlements spoke some Arabic as compared with 82 per cent of those in self-settling.

Given the short sojourn (average 5 years) of most of the rApondents in the Sudan, a high rate of intermarriage with the local population could not be expected. However, given the preponderance of young male refugees particularly in the urban areas and the restrictions imposed by the Sudanese society on sexual behaviour, we had expected a higher rate of intermarriage. Very few of the refugees who had lived in the Sudan even for longer periods had marriage relations with their hosts. According to our informants and our own observations, economic factors (refugee poverty), and cultural and religious incompatibilities were the primary hindrances to intermarriage.

One of the variables which we have proposed as an indicator of social integration is membership in both host and refugee-based voluntary organizations. Our findings indicated that none of the respondents were members of host voluntary organizations. This shows the lack of integration between respondents and their hosts at the neighbourhood and social-organizational levels. It implies the external isolation of the refugee communities. Various factors seem to function as barriers to integration at this level. Linguistic and cultural differences were the primary obstacles. Refugees also found membership in host voluntary associations unsuitable for their specific needs or even threatening to their identity. In addition, few Sudanese seem to be willing to form associations and partnerships with refugees, mainly because of the legal status of the latter. Even Sudanese labour unions bar refugees from membership.

Some of the refugee groups in the Sudan are internally organized and integrated to 
some degree through voluntary associations, to which about 25 per cent of the respondents belonged. These refugee voluntary organizations were not entirely the products of exile since some of them were rooted in traditional forms of social organization in the society of origin. However they have wider social, psychological, cultural, economic and political functions than similar associations in Ethiopia.

The rate of membership among respondents varied considerably according to the type of settlements covered. About 44 per cent of the self-settling respondents and only 15 per cent of those who were interviewed in the organized settlements belonged to voluntary organizations of one or another sort. These differences can be construed as a function of the social structure of the communities, the role of aid in the creation of dependency and the attitudes of aid workers and administrators regarding refugee participation in decision-making. Voluntary associations suggest self-reliance and participation, and their absence implies the opposite.

Life in the refugee communities is marred by a certain degree of personal, interpersonal and intergroup conflict which in various ways tends to affect social integration. Conflicts occur between refugees and their hosts as well as among refugees themselves. The refugee-host conflicts which occur less frequently have objective and subjective ramifications. They arise mainly from competition over resources as well as from cultural and religious differences. The large influx of refugees from Ethiopia has had a great impact on the economy of the Sudan. The impact is greatest upon the poorer sections of the host society. The abundance of labour has, in certain areas, driven down wages and priced the locallabour out of the market. In urban areas, the presence of refugees has been exploited by landlords to raise house rents. Thus directly or indirectly the influx has affected the lives of poor local households whose reaction is sometimes resentment.

The conflicts among refugees themselves seem to be more frequent, profound, and destructive of life and property, and causing anxiety and insecurity among the respondents. Frustration and drinking, which primarily result from the condition of exile, as well as political, ethnic and religious differences among refugees are the major causes of this type of conflict.

In general, the study indicates only a slow rate of refugee social integration. The speed and rate of integration varies among different categories of refugees. Respondents from the self-settling communities, particularly those from the urban areas, were more integrated in the global host society than those in the organized settlements. Those in organized settlements are not only spatially segregated but are also socially isolated to a greater degree than self-settlers. There is very little interaction between them and the local population, whose language only a minority speak. The refugee communities of the organized settlements are weak at all social levels. The refugee family/household, particularly in the organized settlements, is characterized by the lack of a male head of household due to employment elsewhere in the Sudan or migration to another country. The household is weakened by the continuous out-migration of its young and healthy members searching for jobs and education outside of settlements. At the level of the neighbourhood there is a lack of mutual trust and a very low rate of participation in voluntary associations. Interpersonal and intergroup conflicts plague organized settlements, causing material and psychological damage. Thus, organized settlements show signs of profound internal disorganization with negative implications for integration at the community and inter-community levels. 


\section{Cultural and Psychological Aspects of Adjustment and Integration}

\section{Introduction}

Uprooting is widely recognized as a phenomenon that entails psychological problems. It is more than the physical absence from home. It may involve disturbances in the inner balance of individuals. This dissonance of inner balance with displaced persons is often a function of the inability to change ways of living and outlooks, as well as the inability to "transplant" and develop an inner relationship with a new environment (Pfister-Ammende, 1973:14). Pfister-Ammende noted that many migrants abandon the better material standards that they acquire in the host countries and repatriate as a consequence of the failure to establish satisfactory affectivelinks with the new environment.

The inability to settle in a host environment is even more likely among refugees than voluntary migrants. Refugees may gain self-sufficiency or achieve a reasonable degree of socio-cultural integration in the host society, but may find it difficult to adjust psychologically to the new environment. One of the main factors which blocks the "psychological integration" of refugees is their failure to acknowledge for years that their exile may be long or even permanent. "They instead fervently believe that their exile is temporary and that all of a sudden a radical change . . . will upset the status quo and enable them to return home" (Baskauskas, 1981:280).

Generally, psychological adjustment is perceived as a process of establishing and maintaining a relatively stable reciprocal relationship with the social environment (Cohon, 1981:257). However, while adjustment to the social environment of the host society is an important element in the overall integration process, it is also necessary that the migrants overcome the "crisis of discontinuity" and deprivation and reach a "reconciliation" with the realities of the new environment. This latter part seems to be the most difficult aspect of psychological adjustment for refugees to achieve (Baskauskas,1981). Thus, psychological adjustment can generally be proposed as a function of the actors objective and subjective experiences and judgements concerning host country situations and pre-flight life-conditions.

A review of the literature concerning migration indicates a refugee tendency to develop what in the parlance of psychologists is called the "social displacement syndrome". This maladjustment syndrome is characterized by suspiciousness or paranoid reactions, a sense of insecurity, guilt and anxiety about relatives left behind and somatic complaints lacking objective causes (Tyhurst, 1951; Cohon, 1981). 


\section{Causes of Refugee Maladjustment}

Maladjustment in the country of immigration is considered in terms of both relative and absolute deprivation. There are several reasons for deprivation and maladjustment in a situation in which refugees find themselves.

\section{Emotional and social isolation}

Primarily, deprivation is related to the high social, psychological and economic price which refugees pay in order to get physical security. Refugee life is marred by disruptions and the abandonment of life goals. Marriage is delayed, education is discontinued and careers are given up. Flight disrupts the individual's original state of belonging to an immediate social environment, which includes the family and the community. Social relations in the rural communities from which most of the respondents originated resembles in many respects what Toennies (1957) conceptualized as gemeinschaft. In gemeinschaft members are oriented to one another cognitively and emotionally. The family is integrated in the community and the individual is part of the mutual support system which characterizes this form of social organization. Uprooting impairs the relation of the individual to this social organization. The result of such disruption is often the loss of the love and security which the individual enjoyed as a member of the family and the community. As was indicated previously, a large majority of our respondents had been affected by such loss. According to our findings, 17.4 per cent had abandoned their children, 12.3 per cent had left behind their spouses, 12.3 per cent their parents, 39.9 per cent their siblings and several of the young respondents their fiancés. Separation from family and community often causes a relational defecit that may be characterized as the "loneliness of emotional and social isolation" (Weiss, 1973:18). According to Weiss, emotional isolation is caused by the absence of close emotional attachment or the attenuation of the intense and intimate relations between family and kin. Social isolation is initiated by the absence of socially integrative relationships. It is "associated with the absence of an engaging social network" (ibid. p.19). Feelings of aimlessness and marginality seem to be the mark of social isolation. Through flight, the individual is not only forced out of the social network, but he is also alienated from the objects of his self-identity. Ernst Boesch suggests that,

The home . . . forms a symbolic space, containing areas and objects of subjective meaning, representing the past of the individual as well as his values and purposes. Such objects may be few in number and poor in appearance, yet they contribute to an individual's self-identity $(1982: 55)$.

For some of the refugees, the little social security which survived flight is denuded further by the harsh conditions of exile. Poverty and illness put a heavy strain on marriage and divorce is quite common. Furthermore, many of the young refugees are unable to build families because of poverty (cf., Spring 1982:41) and a lack of marriage partners. In some of the organized settlements like Tawawa and among almost all of the self-settling refugees of eastern Sudan, there is an imbalance in the sex ratio. This may lead to emotional frustration and isolation.

Furthermore, the disintegration of the family and of the primary group relations is 
exacerbated by employment conditions in the host country. As has been noted in Chapter 7 a large proportion of the heads of households that were covered in our survey were agricultural labourers who were absent from their home and families for several months each year. Many refugees re-emigrate within the Sudan or to other countries in the Middle East in search of jobs, leaving behind their families. To a large number of respondents separation from home does not only mean the loss of social and psychological support but it is also a cause for feelings of guilt and anxiety which in certain ways exacerbate maladjustment.

\section{Situational variables causing maladjustment}

We asked our respondents whether they were adjusted to the new environment or if there were specific host country related problems which make their adjustment difficult. As is shown in Table 9.1 about 30 per cent of the respondents said that they were more or less adjusted to their new environment and life. The majority, that is about 70 per cent, said that they had adjustment problems. The least adjusted refugees were found in the spontaneous rural settlements of Yabus and Muguf where only about 10 per cent of the respondent said they were adjusted. In the other six settlements the proportion of respondents that said that they were adjusted to their new environments varied between a quarter and a third of the sub-samples.

A variety of problems were given as causes for maladjustment. Many respondents gave more than one problem as the reason for their lack of adjustment. As shown in Table 9.2 economic problems, food (not lack of food but the kind of food available), cultural and religious differences were the major problems blocking adjustment. Climatic conditions, health problems and the lack of water were also given by more than 5 per cent of the respondents as reasons for maladjustment.

Economic and housing problems are the major causes of dissatisfaction. Few refugees succeeded in transfering cash and property to their countries of asylum. Hence flight entails instant impoverishment whereby even the rich turn into penniless dependants on welfare (if available). In our study about 95 per cent of the respondents reported that they had left behind everything that they had had before flight and the majority were unable to make a start towards self-reliance in the new surroundings after even 5 or 6 years.

The majority of the respondents lived in overcrowded conditions, and a large percentage shared their single room tukuls or shacks with other people who were often not relatives or even from the same village. Most urban refugees were concentrated in the filthiest quarters of the shanty towns and slums. These conditions

Table 9.1 Adjustment (respondent self-evaluation) by sample site (\%)

\begin{tabular}{lccccccc}
\hline & & Damazin & & Um & Um & Yabus & All \\
Responses & Gedaref & Kurmuk & Tawawa & Gulja & Rakoba & Muguf & \multicolumn{1}{c}{ sites } \\
\hline Adjusted & 36.2 & 25.0 & 33.6 & 30.9 & 24.3 & 9.4 & 29.5 \\
Not adjusted & 63.8 & 75.0 & 64.6 & 68.0 & 75.7 & 90.6 & 69.7 \\
No answer & 0.0 & 0.0 & 1.8 & 1.0 & 0.0 & 0.0 & 0.7 \\
\hline Total (\%) & 100.0 & 100.0 & 100.0 & 100.0 & 100.0 & 100.0 & 99.9 \\
\multicolumn{1}{c}{ N } & 69 & 32 & 113 & 97 & 70 & 32 & 413 \\
\hline
\end{tabular}


created social maladjustment and dissatisfaction. Perhaps the conditions of the poorest in the host country's are no better than those of the refugees. However, making such comparisons obscures some important differences between the refugees and the poor citizens. Firstly, the latter did not experience the trauma of uprooting like the refugees but live in their own country with relative dignity, if not economic and social security. Secondly, a citizen of the host country may be very poor but he or she can turn to relatives or the community for assistance and protection. The alienation and deprivation of the refugee is multiple and total. The refugee is deprived not only of his means of subsistence but he is also socially, culturally and linguistically alienated, and is also often legally disadvantaged in his new environment. We mention this not as an underestimation of the abject poverty in which sections of the dispossessed populations live in host countries like the Sudan but to point out that there are differences, often subtle, between poor citizens and refugees which exacerbate the poverty and marginality of the latter. Perlman's observation about marginals fits perfectly well the situation of many of our respondents.

Marginals are not simply that group of the population that occupies the lower rungs of the social scale. They are actually off such a scale. Marginals have no position in the dominant social system, not even as its lower class (Perlman, 1976:119).

Weather conditions were mentioned by 8.5 per cent of the respondents as one of the reasons for their maladjustment in their new environment. Although the eastern Sudan and Ethiopia lie in the same latitude, there are great altitudinal and climatic differences between the two countries. Ethiopia is roughly divided into four altitude categories: the central plateau, the savana zones of the western and southwestern border regions and the arid lowlands of the eastern, north-and southeastern provinces. In the central plateau the altitude ranges between $2000 \mathrm{~m}-3500 \mathrm{~m}$ and the average month in temperature is $10-20^{\circ} \mathrm{C}$. The climate varies from temperate to sub-tropical according to the altitude.

Table 9.2 Reasons for maladjustment by sample site (\%)

\begin{tabular}{|c|c|c|c|c|c|c|c|}
\hline Reasons & Gedaref & $\begin{array}{l}\text { Damazin } \\
\text { Kurmuk }\end{array}$ & Tawawa & $\begin{array}{l}\text { Um } \\
\text { Gulja }\end{array}$ & $\begin{array}{l}\text { Um } \\
\text { Rakoba }\end{array}$ & $\begin{array}{l}\text { Yabus } \\
\text { Muguf }\end{array}$ & $\begin{array}{l}\text { All* } \\
\text { sites }\end{array}$ \\
\hline $\begin{array}{l}\text { 1. Economic } \\
\text { (difficulties) }\end{array}$ & $45.5^{* *}$ & 12.5 & 32.9 & 57.6 & 32.0 & 90.6 & 45.1 \\
\hline differences & 59.0 & 4.2 & 74.0 & 36.4 & 64.2 & $0.0^{* * *}$ & 48.3 \\
\hline 3. Diet & 11.4 & 4.2 & 23.3 & 54.5 & 58.5 & 34.5 & 34.7 \\
\hline 4. Climate & 9.0 & 4.2 & 8.2 & 9.0 & 0.0 & 17.2 & 12.5 \\
\hline $\begin{array}{l}\text { 5. Health } \\
\text { problems }\end{array}$ & 0.0 & 79.1 & 4.1 & 0.0 & 7.5 & 65.5 & 10.8 \\
\hline 6. Lack of water & 6.8 & 0.0 & 16.4 & 0.0 & 15.0 & 0.0 & 9.0 \\
\hline $\begin{array}{l}\text { problems } \\
\text { pror }\end{array}$ & 11.4 & 25.0 & 9.6 & 0.0 & 7.5 & 6.9 & 9.0 \\
\hline Total N & 44 & 24 & 73 & 66 & 53 & 29 & 288 \\
\hline
\end{tabular}

${ }^{*}$ per cent of respondents answering 'unadjusted'

${ }^{* *}$ Multiple responses recorded

*** Nearly 90 per cent of the respondents in Damazin, Kurmuk, Yabus and Muguf were Muslims. 
The majority of our respondents were used to the temperate climate of this zone. However, the eastern and central regions of the Sudan where most of the refugees from Ethiopia have settled are semi-arid lowlands with very hot climates. The average monthly temperature in these regions is often above $35^{\circ} \mathrm{C}$ during the summer months. Because of poverty and the level of economic and social development in these areas, facilities such as electric fans, are beyond the reach of common people. This and the lack of an adequate water supply make the climatic conditions unbearable to the refugees.

As an effect of these environmental and physical changes, and perhaps because of psychological maladjustment, many of the refugees have medical problems which as they (7.3 per cent) mention also contribute to dissatisfaction with life in the Sudan. As a consequence of environmental change many refugees were exposed to new diseases like malaria and ill-health is widespread. Because of the living conditions some endemic diseases like tuberculosis have become epidemic in the refugee communities.

Health can be considered as a function of the adaptive demands which the environment places upon the individual (Zwingmann, 1973:38). Therefore, changes like spatial and social separation are important environmental variables that may have impact on the state of health. The inability to understand and cope with a new environment due to language and cultural differences could lead to psychological and psychosomatic problems.

\section{Acculturation: Indicator of Adjustment or a 'Passing' Mechanism}

"Acculturation, simply defined, involves the borrowing or acquisition of cultural traits of one society by people from another society" (Shannon and Shannon, 1973:35). In the refugee situation acculturation can be seen as a positive orientation towards the new community and the loosening of bonds with the community of origin. However, acculturation is not always an indicator of change in values. It could also be an external change as a survival strategy. Such a strategy is sometimes referred to as "passing". Passing occurs usually wherever the host society is homogeneous and "exacts the price of assimilation in exchange for the privilege of admitting the refugee" (Kunz, 1981:48) or when an individual or a minority group considers it wise to operate according to norms that are uphold by the powerful majority without necessarily accepting and internalizing them (Himmelstrand, 1971:261). Under such circumstances the refugee is obliged to accept certain changes in his habits, behaviour and life-style in order to satisfy his basic physical and social needs.

It is very difficult to measure acculturation, particularly when this involves values and behavioural changes. Our assessment of respondent acculturation is based mainly on their subjective responses to the questions we put to them. The responses were supplemented by our observations regarding the habits and life-styles of refugees during the fieldwork.

About 36 per cent of the respondents said that they had adopted some of the habits 


\begin{tabular}{lccc}
\hline & \multicolumn{3}{c}{ Type of change } \\
\cline { 2 - 4 } Reason for change & Food habits & Costume & Religion \\
\hline Acceptance & 31.0 & 85.1 & 100.0 \\
Climate & 0.0 & 4.1 & 0.0 \\
Lack of alternative* & 63.8 & $10.7^{*}$ & 0.0 \\
Desire & 5.1 & 0.0 & 0.0 \\
\hline Total (\%) & 99.9 & 99.9 & 100.0 \\
No. of responses & 158 & 121 & 1 \\
\hline
\end{tabular}

* There are certain ambiguities regarding responses in this table.

Lack of alternative in relation to clothing could for example mean:

1. 'I couldn't find the type of clothes I used at home'

2. 'The clothes I used at home don't suit this climate'.

and life-styles of their hosts. However, changes of some significance were made in only two areas: costume (29.3 per cent) and food habits ( 14.5 per cent). Only one person admitted conversion to Islam. From a socio-psychological point of view it is necessary to determine whether those changes which manifest external acculturation actually reflect an "inner" adjustment and affiliation to the host society, or whether they denote a passing strategy. Hence the respondents were asked why they had adopted the costume and food habits of their hosts. As shown in Table 9.3, about 65 per cent of the responses to this question indicate that the changes were made in order to gain the acceptance of the host society. This particularly concerns the costume worn by women. Refugee women who use their shamma or other folk costumes which leave their legs and arms bare are considered indecent and are sometimes harassed by men. Therefore, many of the female refugees, particularly in the spontaneous settlements have changed their shamma to the taub used by the Sudanese women. Even some male refugees have switched from their traditional jodhpurs to the jalabiya. Although some of the refugees may have been obliged to change their costume because of the climate, it seems that there are also those who use the Sudanese costume to camouflage their laaji (refugee) identity.

\section{Food habits}

The other area where some acculturation seems to have occurred is food habits. The significance of food habits as sociological realities have been noted by students of migration and research has established that food habits constitute some of the most resistant elements in the acculturation of migrants and refugees (Freedman, 1973:15). Freedman suggests that food is a useful predictor of immigrants' general "external assimilation". This is not, however, to deny the psychological meaning which food habits have for refugees and migrants. Grandjean maintains that

... one of the first consequences of the malaise due to failure to assimilate is the immigrants' dislike of the local food, which may go as far as a hunger strike (cited in Freedman, 1973:16).

Almost everywhere immigrants retain the food habits of their countries of origin. However, the need for adjustment often enforces changes in food habits. Just as with 
costume, there are also clear differences in food habits between the Sudanese and Ethiopians. In general the Ethiopian refugees in the Sudan have maintained their food culture. Even though grain such as teff and other products are not available, they have substituted them by local products in the preparation of their food. Small "restaurants" which serve Ethiopian food are abundant in the organized settlements and the larger urban areas and, as we have already mentioned, many of the refugee women earned their living by making and selling injera (Ethiopian bread). The data indicate that about 90 per cent of the respondents almost always ate Ethiopian food while only 10 per cent had switched to Sudanese food.

\section{Religion}

One of the factors mentioned by interviewees as a major hindrance to their adjustment in the Sudan was religious differences. Religious differences do not usually lead to open and direct conflicts between refugees and their hosts. In fact, despite the growing religious fundamentalism in the Sudan, most Sudanese are very tolerant of other peoples' beliefs and very friendly to non-Moslems. Futhermore, the southern part of the Sudan is inhabited by Christians. However, for the Christian refugees living in the predominantly Moslem regions of the Sudan, religious differences, seem to be an obstacle to adjustment, although mainly at the psychological level.

Life in exile magnifies the sense of cultural distinctivenessand isolation (Williams, 1972). This is further exaggerated when the distance between the cultures of the hosts and societies of origin is wide, as with our respondents and the Sudanese. Most of the respondents originated from areas in Ethiopia where Christians have always been the majority and where the dominant culture and institutions have their roots in Christianity. They were also used to a situation where Christians dominate and rule non-Christians. Some of the Christian rulers used to refer to their country (Abyssinia) as "an island of Christianity in a sea of pagans". Some of those "pagans" were Moslems. In order to create unity among the Christians, Abyssinian rulers and religious leaders depicted non-Christian peoples as a threat to their existence and their Christian culture, which was considered superior.

The Ethiopian Orthodox (Coptic) Church is the established church'of the empire. Its members, almost entirely Amhara-Tigrai peoples believe themselves the "chosen people" in communion with God and the world of saints and spirits. It is the major base of their ethnic identity, and observance of its forms, which permeates every aspect of the daily life and thought of its adherents, gives unity to Amhara-Tigrai culture (Lipsky, 1962:100).

For many of the refugees the host environment constitutes a negation of their world view and those values they have internalized deeply prior to their flight. Weaver observed that:

Many . . . Ethiopians simply may be unable psychologically to accept their presence in the Sudanese society, which is very different from their indigenous experience. These young people may subconsciously refuse to become part of a society in which they are aliens. Christan refugees may resist putting down roots in a Islamic culture which openly rejects most of their beliefs and lifestyle (1985:153).

The majority of the study population seems to adhere strongly to their reliigous values and practices. As a mark of their faith many of the Christian refugees have fixed wooden crosses on the pinnacles of their tukuls. This practice is not very 
common in the country of origin. Furthermore, fasting is strictly observed and the Christian holidays are celebrated with vigour and festivity. In spite of their poverty, refugees in the settlement of Um Gulja contributed an impressive sum of about £S 50,000 towards the construction of a brick and concrete church in 1983 .

The reactions exhibited by our respondents are manifestations of conservatism and indicate the resistance to change which has also been observed among refugees elsewhere (Zwingmann, 1973). The reactions may also imply nostalgic feelings about the place of origin and events and objects that are associated with it. Edward Shils proposes that:

There is much sentiment about the place where one originated but it becomes articulate usually after departure from that place . . . perhaps no awareness of attachment arises until there is an actual or threatened displacement. Generalized appreciation or attachment to a place of past location occurs only after the loss of the object itself (1978:405).

Things past are made vivid by the unacceptability of the present, and people adopt a security orientation by clinging to old behavioural patterns, old institutions and goals (Williams, 1972; Hansen, 1982:33). Thus the response to the threat of change is conservatism which is expressed sometimes in "an intense and radicalized desire to preserve the totality of their culture in the new milieu . . .(Baskauskas, 1981:280).

Sentiments about the place of origin are maintained and expressed by preserving its cultural forms such as food habits, costume, religion, language and by celebrating its historical and cultural landmarks. These cultural aspects and the celebrations are visible, collective expressions of identity which enable refugees to maintain group boundaries. The sentiment usually does not emanate from, nor is meant to express, animosity to others. It is just part of the refugee unconscious plan to keep alive the hope of returning home. Acculturation works against this long-term plan and hence is resisted.

\section{Education and Acculturation}

Even in the areas of education, cultural and religious differences between the refugees and their hosts pose an intractable obstacle to integration. Many of the refugee parents were aware of the role of education in socializationand the transmission of values and were in a dilemma regarding the education of their children. The root of this worry was the association of religion and education by these parents as a result of their experiences in the country of origin. In the peasant communities of northern Ethiopia from which such refugees originate, the village priest is the school teacher and the church is often the village school. Hence, parents consider that sending their children to Sudanese schools, where Arabic, a language which they associate with Islam, is the medium of instruction and where Koranic studies are part of the curriculum, means that the children will learn values which are in many respects different from their own.

Other refugee parents who are aware not only of the role of education in socialization but are also conscious of the importance of education for their children's success in life were faced with the dilemma of striking a balance between these two conflicting situations (El-Bushra, 1982.) Withholding children from the Sudanese educa- 
Table 9.4 Childlren's school attendance (\%)

\begin{tabular}{lc}
\hline School Attendance & $\%$ \\
\hline Yes & 48.3 \\
No & 38,3 \\
No response (had school aged children) & 13.4 \\
\hline Total (\%) & 100.0 \\
$\quad \mathrm{~N}$ & $209^{*}$ \\
\hline
\end{tabular}

* 204 households or $49.4 \%$ of the respondents dit not have children that had reached school age at the time of the survey.

tional system means sacrificing their chances of success in the host society. Allowing their integration into the system, on the other hand, means risking a loss of identity and probably an eventual loss of the desire to go home.

Not all refugee parents face this dilemma, as about 20 per cent of the respondents are Muslims and were less reluctant to send their children to Sudanese school when the opportunity was available. Our data show that refugee parents handle the dilemma in different ways. As shown in Table 9.4, about half of the refugee households covered by the survey had children of school age (6-16 years). About 50 per cent of the households who had school-aged children sent them to school whereas 38.3 per cent did not. The rest, 13 per cent, did not respond. Slightly more than half (53.9 per cent) of the children who went to school were integrated into the Sudanese educational system (Table 9.5). They attended Sudanese public schools and their education followed more or less that of the Sudanese children. The rest went to different schools run by refugee organizations and voluntary agencies. We also found that wherever schools run by voluntary agencies and refugee organizations were available, refugee parents preferred these to Sudanese public schools although their quality of those schools was often much lower.

More than a third of the refugee parents did not send their children to school because of economic, attitudinal and other obstacles. In many developing countries, children are unable to attend school because their parents cannot afford to pay school fees, buy school materials and uniforms and/or because the children are obliged to work to support themselves and their families. Thus, it is not surprising that economic problems were mentioned by refugee parents as a major obstacle to their children's schooling. As shown in Table 9.6, out of the 80 households that did not send their children to school, 51.3 per cent gave economic problems as the major obstacle. What is very interesting is that in 30 per cent of the cases it was parental

Table 9.5 Types of schools attended by refugee children (\%)

\begin{tabular}{lc}
\hline Type of school & $\%$ \\
\hline Public school & 53.9 \\
Schools run by voluntary agencies & 32.3 \\
Schools run by Liberation Fronts & 7.8 \\
Religious schools & 5.9 \\
\hline Total (\%) & 99.9 \\
$\quad \mathrm{~N}$ & 101 \\
\hline
\end{tabular}


Table 9.6 Reasons given by refugee parents for not sending their children to school

\begin{tabular}{lc}
\hline Reasons & $\%$ \\
\hline Economic (children working etc.) & 51.3 \\
Lack of school & 6.3 \\
Health & 8.8 \\
Parental attitude and unawareness & 29.7 \\
Language & 1.3 \\
Lack of birth centificate & 2.5 \\
\hline Total (\%) & 99.9 \\
$\quad \mathrm{~N}$ & 80 \\
\hline
\end{tabular}

attitudes, including a reluctance to put their children in Sudanese public schools, which was the hindrance. Other problems such as the lack of a school (6.3 per cent) health ( 8.8 per cent), lack of birth certificate ( 2.5 per cent) and language ( 1.3 per cent) were also mentioned as reasons for not sending children to school.

Educational policies of host countries and research reports about refugee education are most often concerned only with structural problems and pay little or no attention to the fears and concerns of refugee parents. This is understandable in the light of the conditions in most of the host countries. However, since education is a key factor for the success of refugees in the socio-economic systems of their host societies, or for reintegration into their own society when voluntary repatriation is possible, it is important that structural as well as social psychological obstacles to education are minimized as much as possible.

The integration of refugee education into the national school system is necessary from the long-term development perspective. Nevertheless, it is also possible at the same time to make allowance for the worries and suspicions of refugee parents in a situation where there are cultural and religious differences between hosts and refugees. For example, religious subjects could be made optional for refugee children and a basic knowledge of the history and geography of the country of origin could be provided without straining resources. This would encourage refugee parents to send their children to school.

\section{Insecurity, Anxiety and Guilt}

It is evident from the foregoing discussion that the majority of our respondents were poorly adjusted to their new environment. When an immigrant cannot adjust to his new community and is unable or unwilling to return to the old he finds that he does not belong to any community. He is uprooted and marginalized. In her study of refugees in Switzerland, Maria Pfister-Ammende reports reactions

which are common to persons uprooted from their social milieu and compelled to flee. Some of these reactions constitute: a fear of the persecutor with a subsequent tendency to develop anxiety when the real danger is over, coupled with the projection on neutral persons of the new environment (Pfister-Ammende, 1973:7).

In a study made among Rwandese refugees and migrants in Uganda, Bennet and 
Table 9.7 Fear by sample site (\%)

\begin{tabular}{lccccccc}
\hline \hline \multirow{2}{*}{ Feelings of fear } & Gedaref & Kumazin & Um & Um & Yabus & All \\
& Kurmawa & Gulja & Rakoba & Muguf & Sites \\
\hline Often & 55.1 & 66.7 & 53.1 & 33.0 & 10.0 & 78.1 & 41.4 \\
Sometimes & 26.1 & 16.7 & 17.7 & 14.4 & 32.3 & 12.5 & 23.0 \\
Never & 17.4 & 16.6 & 24.8 & 43.3 & 54.3 & 9.4 & 30.5 \\
No answer & 1.4 & 0.0 & 4.4 & 9.3 & 1.4 & 0.0 & 5.0 \\
\hline Total (\%) & 100.0 & 100.0 & 100.0 & 100.0 & 100.0 & 100.0 & 99.9 \\
\multicolumn{1}{c}{$\mathrm{N}$} & 69 & 32 & 113 & 97 & 70 & 32 & 413 \\
\hline \hline
\end{tabular}

Assael (1970:321-335) found alcoholism, depression and anti-social behaviour to be common problems. Social isolation, insecurity and cultural disorientation were identified as the grounds for the predominance of these characteristics. They concluded that the handling of acute stress-adjustment is most important in the initial phases of acculturation in the new physical and social environment

In Norway, Eitinger and Grunfeld (1966) observed that the incidence of psychoses was five times greater among refugees than among the resident population. The main causes of "this remarkably high rate of the incidence of psychoses of which the paranoid syndrome was one of the most common forms of manifestation" were attributed by the authors to the problems of isolation (linguistic and social), maladaptation and the lack of a feeling of security. Other writers have argued that the negative experiences which the refugee undergoes before and during his flight are contributing factors to maladjustment in the host environment. The trauma of flight produces residual psychological states in the refugee that may affect behaviour for years (see Stein, 1981:323). In addition, the oppression and persecution experienced by refugees before and during the initial stages of flight may bring about personality derangements which operate against adjustment (Weinberg, 1961:110). On the whole, refugee maladjustment as manifested by insecurity and anxiety is the combined effect of uncertainty in, and mistrust of, the new environment and the personal deprivation caused by uprooting. Tyhurst in an article titled "Displacement and Migration" pointed out that,

Some are depressed about their loss of home, and many feel guilty about having left their parents. In this regard some of the depressive reactions could be considered as delayed grief reactions, precipitated by feelings of guilt. However, in others the reactive elements to the present situation are more important, having to do with the dynamics of frustration and hostility (Tyhurst, 1951).

We asked respondents three main questions pertaining to fear or insecurity felt by them in the host society, about their anxiety concerning their relatives and feelings of guilt for leaving them behind. The first question we put to them was "Do you ever fear or think that something very bad could happen to you because you are a refugee?" The answers to this questions were (Table 9.7) "feel fear often" 41.4 per cent, "feel fear only sometimes" 23.3 per cent and "do not feel insecure at all", 30.5 per cent. About 5 per cent of the respondents were unwilling to answer this question. All in all, 64.4 per cent of the respondents felt that they were particularly exposed to some sort of "danger" because of the circumstances in which they find themselves as refugees. 
As is indicated in Table 9.8, the anticipation of forced repatriation is the most frequent cause of anxiety and was expressed by $\mathbf{3 3 . 2}$ per cent of the respondents. The frequency, however, varied significantly between sample sites. Insecurity regarding anticipated refoulement (forced repatriation) was felt by 68.5 per cent in Gedaref, 41.6 per cent in Tawawa, 21.6 percent in Um Gulja, 12.5 per cent in Kurmuk. None of the respondents in the two spontaneous rural settlements of Yabus and Muguf reported such anxiety.

In addition to forced repatriation, 'legal' insecurity was also expressed as a fear of imprisonment by 5-10 per cent of the respondents in Gedaref, Um Gulja, Um Rakoba, Damazin and Kurmuk. In the semi-urban organized settlement of Tawawa and the spontaneous rural settlements of Yabus and Muguf, none of the respondents anticipated imprisonment in the Sudan. Anxiety in this regard was caused by the fear that policies could change, resulting in the detention of refugees. It was also feared that imprisonment could result from misunderstandings between respondents and the Sudanese authorities or employers, against whom refugees might not be able to protect themselves as aliens.

Next to legal insecurity (forced repatriation and imprisonment), the most frequent cause of anxiety was host - refugee relations. This intergroup anxiety stemmed from the respondent fears for their physical security, and was expressed as the "fear of assault" and the fear that someone would set fire to their tukul. Inter-group anxiety was also expressed in terms of loss of socialstatus and feelings of threatened identity. In this connection respondents expressed fear of discrimination, exploitation and domination by the relatively powerful hosts. The fear of hostile treatment is partly grounded on objective reality and the experience of inter-group conflict discussed in Chapter 8 , but is also partly an outcome of subjective evaluations and irrational anticipation.

Military attack on their settlement is another anticipated danger that causes anxiety among respondents. Attacks on refugee settlements across international borders by home country forces are becoming more common in Africa. But no such incident had been reported along Ethio-Sudanese borders. However, refugees living in the border areas were often threatened by the presence of Ethiopian military units near the border and the on-goings conflicts between them and the liberation fronts.

Table 9.8 Type of fear reported by respondents by settlement site (\%)

\begin{tabular}{|c|c|c|c|c|c|c|c|}
\hline Type of fear & Gederef & $\begin{array}{l}\text { Damazin } \\
\text { Kurmuk }\end{array}$ & Tawawa & $\begin{array}{l}\text { Um } \\
\text { Gulja }\end{array}$ & $\begin{array}{l}\text { Um } \\
\text { Rakoba }\end{array}$ & $\begin{array}{l}\text { Yabus } \\
\text { Muguf }\end{array}$ & $\begin{array}{l}\text { All } \\
\text { Sites }\end{array}$ \\
\hline 1. Forced repatriation & 68.5 & 12.5 & 41.6 & 21.6 & 27.1 & 0.0 & 33.2 \\
\hline 2. Imprisonment & 8.7 & 6.3 & 0.0 & 9.3 & 5.7 & 0.0 & 5.1 \\
\hline 3. Hostile treatment & 21.7 & 6.3 & 18.6 & 13.4 & 2.9 & 3.1 & 15.5 \\
\hline $\begin{array}{l}\text { 4. } \\
\text { across border }\end{array}$ & 0.0 & 6.3 & 0.0 & 1.0 & 4.3 & 93.6 & 8.5 \\
\hline 5. Starvation & 4.7 & 9.4 & 0.0 & 7.2 & 1.4 & 12.5 & 6.5 \\
\hline 6. Anything & 5.8 & 0.0 & 8.0 & 2.1 & 8.6 & 3.1 & 5.6 \\
\hline 7. Feel no fear & 17.4 & 16.6 & 24.8 & 43.3 & 54.3 & 9.4 & 30.5 \\
\hline 8. No answer & 1.4 & 0.0 & 4.4 & 9.3 & 1.4 & 0.0 & 5.0 \\
\hline $\mathrm{N}$ & 69 & 32 & 113 & 97 & 70 & 32 & 413 \\
\hline
\end{tabular}

1-6 multiple responses recorded. 
Thus anxiety regarding military attack was felt mainly by respondents who have settled just near the border in Yabus and Muguf (93.6 per cent), Damazin and Kurmuk (6.3 per cent) and Um Rakoba (4.3 per cent). Respondents living further away form the border areas rarely anticipated that they would experience such a danger.

Economic anxiety was felt by only 6.5 per cent of the respondents. This was expressed as an anticipation of difficultiesand starvation due to lack of employment or the inability to produce enough food for oneself or one's family. Such fear was reported by 4.7 per cent of the respondents in Gedaref, 7.2 per cent in Um Gulja, 1.4 per cent in Um Rakoba 9.4 per cent in Damazin and Kurmuk and 12.5 per cent in Yabus and Muguf. About 6 per cent of all the respondents felt insecure because as refugees "anything could happen to them".

\section{Operative Variables in the Generation of Fear and Anxiety}

In the multivariate conceptual scheme presented in Chapter 4 we proposed that refugee integration in the host society is a function of the dynamic interaction of variables operating prior to and after migration. These sets of variables are, therefore, relevant to the study of the psychological adjustment of respondents in the host environment. The analysis of our data reveals interesting associations between anxiety, pre-flight and post-flight variables such as reasons for flight, life experiences of the respondent, sex, economic opportunity, homogeneity/heterogeneity of the respondents' immediate social environment and the length of residence in the host society.

\section{Pre-flight Variables: Causes of Flight}

It is argued by psychologists that the different conditions encountered by ordinary immigrants and refugees during immigration and flight tend to exaggerate the consequences of mobility in the refugee, making it a more psychological experience. The sudden separation from home, the stress caused by flight and pursuit are also likely to arouse anxiety which could contribute to false evaluations of situations and disorientiation in the new surroundings.

It is also well known among social workers, physicians, psychiatrists and others who deal closely with refugees that many of those who have been imprisoned and tortured harbour the delusion of being followed. The sight of a policeman or an object associated with the previous environment may arouse panic in them. Thus some victims of persecution continue to suffer from feelings of danger long after having left the environment in which the persecution took place.

Our respondents expressed their anxiety as the "fear of imprisonment", "fear of massacre", "fear of military attack on (their) settlement", "fear of forced repatriation", "fear of arson" etc. Some of the dangers mentioned here were potentially there in the new environment but were neither present at the time of the survey nor 
Table 9.9 Frequency of respondents reporting fear by reason for flight (\%)

\begin{tabular}{lccc}
\hline & \multicolumn{2}{l}{ Reason for flight } & \\
\cline { 2 - 3 } Feelings of fear & 'Political' & 'Non-political' & Total \\
\hline Often or sometimes & $\mathbf{7 2 . 2}$ & $\mathbf{4 6 . 4}$ & $\mathbf{6 7 . 3}$ \\
Never & $\mathbf{2 7 . 8}$ & $\mathbf{5 3 . 6}$ & $\mathbf{3 2 . 7}$ \\
\hline Total (\%) & 100.0 & 100.0 & 100.0 \\
$\quad$ N & 323 & 69 & 392 \\
\hline
\end{tabular}

$\mathrm{X}^{2}=\mathbf{1 7 . 5 2}, 1$ d.f., $\mathrm{p}<.001$. No ans. $=\mathbf{5 \%}(\mathrm{N}=\mathbf{2 1})$.

experienced prior to that. We also.found that some of the fears expressed by refugees had concrete causes and were the result of specific and objective experiences. However, from our observation of the host environment we felt that some of these fears were exaggerated. But, since the reasons given for fear were similar to the pre-flight concrete experiences of some of the respondents, it is reasonable to look for an explanation in that direction.

We saw in Chapter 5 that the reasons given by respondents for their flight were (a) fear of danger, (b) persecution, (c) opposition (d) war, (e) military conscription, (f) forced labour, $(\mathrm{g})$ in voluntary relocation, $(\mathrm{h})$ economic problems and other reasons which were given by those whom we considered borderline cases. If we dichotomize the respondents and categorize those who fled because of man-made situations (a to g) as "political" and those who left for other reasons (h) as "non-political" refugees we find that about 84 per cent of the respondents fall under the first category. These differences in the reasons for departure from home tend to have significant associations with fear in the host environment. As is shown in Table 9.9, about 72 per cent of the "political" refugees felt insecure often or sometimes as compared with 46 per cent of the "non-political" refugees. In other words, only one quarter of the "political" refugees felt safe in their host environment, compared with more than half of the "non-political" refugees. The data suggest a relationship between causes of flight and feelings of insecurity in the host environment. Even when variables such as sex, type of settlement and length of residence in the host country (which were also related to insecurity) were controlled for, the association between cause of flight and fear remained significant. This relationship is supported by Harrell-Bond's study of the Ugandan refugees in southern Sudan. Her observations of the perception of refugee children about their situations is revealing. She wrote:

They saw 'refugee life' in terms of violence ... The children drew pictures of soldiers shooting their mothers, infants lying and bleeding to death, houses burning. They drew pictures of men tied to trees, decapitations, dogs eating human corpses. They drew groups of children and adults crouching in the forest, ribs jutting or bellies swollen with starvation. The word 'refugee' itself seems to be associated in the minds of children with their experiences of violence, death, and starvation (1986:286). 


\section{Insecurity and Post-Flight Variables}

\section{Economic variables}

We noted above that the major reason for respondents' dissatisfaction with life in the Sudan was economic problems. Neverthless, very few (about 7 per cent) of the respondents said that their economic situation was a cause for fear. However, despite the small number of respondents who connect their anxiety with economic concerns, there seems to be fairly strong relationship between the two variables. As is demonstrated in Table 9.10, refugees whose economic conditions deteriorated after flight are somewhat more insecure and anxious than those with stable or improved economic conditions.

Refugees feel economically insecure not only because of a lack of income and the deterioration of their economic welfare due to flight, but also for other reasons. As we have pointed out previously, refugees are vulnerable to exploitation. Self-settling refugees told us that when they attempted to complain about unjust treatment, their employers threatened to report them to the police and have them deported. Those who rented land from the local people were sometimes cheated. Respondents in Um Gulja and Um Rakoba told us that many land-owners revoked their contracts or increased fees after the respondents had cleared the land and made it suitable for cultivation. Concerning the relationship between insecurity and the economic selfsufficiency of self-settling refugees Robert Chambers has remarked:

Self-settled refugees are vulnerable politically and legally. They are easy victims of blackmail, exploitation and expropriation. They can be threatened variously with repatriation and arrest. If they begin to achieve modest economic success, they may become hypervulnerable to harassment or expropriation. They may be kept poor not just by their initial poverty, low wages, lack of work and lack of food, but also by petty persecution and lack of security. They then keep a low profile and avoid investment (Chambers, 1979:388).

Tenural insecurity is also felt even by refugees who had been alloted plots of land by the host government. Here insecurity is the result of a lack of information regarding their rights. In this case, tenure insecurity, according to the refugees themselves, was a hindrance to making improvements on their plots (Kibreab, 1985:138).

Table 9.10 Fear by economic performance in the host country (\%)

\begin{tabular}{lllc}
\hline & \multicolumn{2}{l}{ Economic conditions } & \\
\cline { 2 - 3 } $\begin{array}{l}\text { Feelings } \\
\text { of fear }\end{array}$ & $\begin{array}{l}\text { Better or same } \\
\text { as pre-flight }\end{array}$ & $\begin{array}{l}\text { Poorer than } \\
\text { pre-flight }\end{array}$ & Total \\
\hline Often & 35.7 & 49.3 & 45.8 \\
Sometimes & 22.4 & 20.6 & 21.0 \\
Never & 41.8 & 30.1 & 33.2 \\
\hline Total (\%) & 99.9 & 100.0 & $100.0 "$ \\
\multicolumn{1}{c}{$\mathrm{N}$} & 98 & 282 & 380 \\
\hline
\end{tabular}

$\mathrm{X}^{2}=6.47,2$ d.f., $\mathrm{p}<.05$.

33 respondents dit not answer one or both questions 


\section{Type and pattern of settlement}

Among the structural factors, homogeneity and heterogeneity of the immediate environment and/or the pattern of refugee settlement in the host society show a significant association with security and uncertainty. Respondents from the organized settlements, which were in most cases inhabited entirely by refugees, were less insecure and unsettled than those who lived scattered among the local population. They were less integrated into the host society but seemed to be more equanimous and relaxed than the self-settling refugees. As is shown in Table 9.11, among the self-settling respondents 84 per cent "felt fear often or sometimes" and only 15 per cent "felt no fear" as compared to 56.1 per cent ("fear") and 38.6 per cent ("no fear") among those in the organized settlements. Nearly twice as many self-settling refugees "felt fear often" as those in the organized settlements. Several reasons can be suggested to explain these differences.

Principally, a refugee or a migrant who lives in a culturally and ethnically compatible neighbourhood is likely to draw support from his environment. Even though the extended household system had beer, disintegrated and the mutual support that characterized the respondents' communities of origin drastically weakened, the mere physical proximity of other people of the same culture who speak the same language provided a sense of security.

Assistance was provided by the Sudanese government, UNHCR and a number of humanitarian organizations to those wholived in the organized settlements. Respondents from such sites seemed to draw some feeling of security from the solidarity and the sympathy shown to them. Even though their material deprivation was often similar to that of their self-settling fellow countrymen, the mere presence of these organizations in their settlements made them feel more secure. Self-settling refugees seem to harbour more feelings of helplessness even when, as in the case of Gedaref, their economic conditions are better than those in the organized settlements. Occasions for inter-group conflict are minimized by the spatial distance between refugees located in the organized settlements and the local population, thereby also decreasing inter-group anxiety compared with self-settling refugees.

However, this should not be construed to mean that the social environment in the organized settlements was free from psychological stress. The social relations described in the previous chapter as characteristic of the organized settlements seemed

Tabell 9.11 Fear by type of settlement and of refugees (\%)

\begin{tabular}{|c|c|c|c|c|}
\hline \multirow[b]{2}{*}{ Feelings of fear } & \multicolumn{2}{|c|}{ Type of settlement } & \multicolumn{2}{|c|}{ Type of refugee } \\
\hline & Spontaneous & Organized & $\begin{array}{l}\text { Urban/Semi- } \\
\text { urban }\end{array}$ & Rural \\
\hline Often & 62.8 & 35.4 & 54.6 & 32.2 \\
\hline Sometimes & 21.2 & 20.7 & 20.6 & 21.1 \\
\hline Never & 15.0 & 38.6 & 21.6 & 41.7 \\
\hline No answer & 0.8 & 5.3 & 3.1 & 5.0 \\
\hline Total (\%) & 99.8 & 100.0 & 99.9 & 100.0 \\
\hline $\mathrm{N}$ & 113 & 280 & 214 & 199 \\
\hline
\end{tabular}

Spontaneous/Organized $\mathrm{X}^{2}=26.56,2$ d.f., $\mathrm{p}<.001$.

Urban/Rural $\mathrm{X}^{2}=26.57,2$ d.f., $\mathrm{p}<.001$.

No answer excluded in $\mathrm{X}^{2}$ calculations. 
to contribute to the insecurity of their inhabitants. For the respondents, life in such a large and often heterogenous community was a new experience. The settlements differed dramatically from their villages in the home country. Here, their neighbours were often strangers. There was deep mutual mistrust between neighbours. In Tawawa and Um Gulja, respondents told us that they were afraid to go out during the night and that people did not dare to assist their neighbours if they cried for help.

Conflicts and violence also made life in some of the organized settlements insecure. Conflicts among the inhabitants often resulted in physical assaults or death. One such incident cost 12 lives in Um Gulja in 1982. One of the sample sites (Tawawa) was considered a dangerous place even by aid workers. Medical workers told us they did not dare to go to Tawawa after four o'clock in the afternoon because of the hostility and insecurity that characterized the settlement.

\section{Length of residence in the host country}

Length of residence in the host society showed no significant association with feelings of security. Although the proportion of those who feel fear has decreased from 68.9 per cent among those who have been in the Sudan between one and three years to 62.5 per cent among those who have lived there for eight or more years, the differences are statistically not significant (see Table 9.12). Together with the lack of economic self-sufficiency which has proved persistent irrespective of length of residence, the above results indicate that the over all adjustment of respondents in the Sudan is very slow. It will take them perhaps several decades to achieve a significant level of socio-psychological adjustment and economic integration.

\section{Anxiety and sex}

There was a clear association between fear and sex. As can be seen in Table 9.13, 73 per cent of the men and 58.5 per cent of the women felt or expressed fear. Only 23.7 per cent of men answered "no fear" as compared with 36.9 per cent of the female respondents. More men felt "often insecure" than women. These findings are remarkable because they contradict the objective conditions in the host country and the socialization process and normative expectations of the societies of origin.

In the previous chapter, it was indicated that female refugees are more socially isolated than men in the host society, and that there is much more pressure on them from their hosts to acculturate or comply with host country customs. We also pointed out that female refugees were more often exposed to economic problems than male refugees. Besides, the conditions of exile have enforced upon many women the role

Table 9.12 Fear by length of residence in the Sudan (\%)

\begin{tabular}{|c|c|c|c|c|}
\hline Feelings of fear & $1-3$ years & $4-7$ years & $8+$ years & Total \\
\hline $\begin{array}{l}\text { Yes } \\
\text { No }\end{array}$ & $\begin{array}{l}68.9 \\
31.1\end{array}$ & $\begin{array}{l}67.8 \\
32.2\end{array}$ & $\begin{array}{l}62.5 \\
37.5\end{array}$ & $\begin{array}{l}67.9 \\
32.1\end{array}$ \\
\hline $\begin{array}{c}\text { Total } \\
\text { (\%) }\end{array}$ & $\begin{array}{c}100.0 \\
132\end{array}$ & $\begin{array}{c}100.0 \\
236\end{array}$ & $\begin{array}{c}100.0 \\
24\end{array}$ & $\begin{array}{c}100.0 \\
392\end{array}$ \\
\hline
\end{tabular}

$\mathrm{X}^{2}=0.22$ not significant.

No response $1-3$ years $=7(5.3 \%) 4-7$ years $=13(5.5 \%)$ and $8+$ years $=1(4.2 \%)$. 
Table 9.13 Fear by sex (\%)

\begin{tabular}{lcc}
\hline Feelings of fear & Male & Female \\
\hline Often & 48.7 & 39.8 \\
Sometimes & 24.3 & 18.7 \\
Never & 23.7 & 36.9 \\
No answer & 3.3 & 4.6 \\
\hline Total (\%) & 100.0 & 100.0 \\
\multicolumn{1}{c}{$\mathrm{N}$} & 174 & 239 \\
\hline
\end{tabular}

$\mathrm{X}^{2}=9.55,3$ d.f., $\mathrm{p}<.05$.

of head of household, for which many of them were not prepared at all. What is more, while trying to fulfil the social and economic responsibilities which the role of household head entails, female refugees often break the norms of the host society. Thus, objectively, the conditions of exile are more threatening and insecure for women than men.

In most of the societies in Ethiopia boys are socialized and expected to be "tough" and exhibit bravery in adversity. For a man to show or express fear or anxiety is not proper behaviour. Girls, on the contrary, are taught and are expected to be 'soft' and not aggressive. Fear and cowardice are considered feminine qualities in the societies of origin. Our findings contradict these expectations and normative behaviour.

It is difficult to find specific explanations for the differences between male and female respondents regarding fear or feelings of insecurity in the host environment with the data at hand. However, some assumptions can be made about the relationships between level of aspiration and anxiety. For men, perhaps more than for women, life in exile represents the loss of status and power. In the societies from which the respondents originate, the main role of the male head of household is that of the breadwinner and protector of its members. He gets respect and status in the community and among his peer groups when he performs these expected roles. Therefore, it is the aspiration of every 'normal' male head of household to protect and provide for his family and to enjoy the privilegesand status that accrue from this. Flight and dislocation render this very difficult and in some cases impossible. About two-thirds of the male-head of household were unable to earn enough to feed themselves and their families. This inability to fulfil the traditional role of the head of household could perhaps entail a loss of self-respect. It could also mean a loss of control or power over the members of the household and cause anxiety which is displaced or attributed to other factors by the respondents.

Forced repatriation: cause for widespread anxiety

About 33 per cent of the heads of household we interviewed gave fear of forced repatriation (refoulement) as the main cause of their anxiety. Refoulement is a universal concern of political refugees in Africa (Hansen, 1981) and, therefore, protection is a relevant issue that must be raised when integration is discussed. Obviously those persons who feel constantly threatened by forced repatriation are unwilling and unable to make any meaningful social and economic investment in their host country. 
Elsewhere in Africa the concern about forced repatriation may have objective grounds. As the expulsion of long-time Rwanda residents from Uganda in 1982 demonstrated, there is no ultimate guarantee of protection even after economic self-sufficiency has evidently been achieved(Pitterman, 1983:174). The expulsion of Ghanaian and other migrants from Nigeria in 1984 demonstrated how easily an in-migrating group can be made a scapegoat by regimes that are threatened by economic and political adversities. Refugees often seems to be aware of such danger and hence are plagued by an interminable sense of insecurity and anxiety. In the Sudan, the suspicion regarding refoulement stems mainly from a lack of information about the existing system of international protection and the asylum policies of the host government. Hence the disquieting feeling among refugees that they are at the mercy of the whims of the hosts and the political climate in the country of asylum. Evacuations of refugees from the urban centres because of congestion or unemployment are often interpreted as preparations for forcible repatriation. Every exchange of official visits between the Sudan and Ethiopia is suspected by refugees as an occasion for negotiation about their fates and an ominous prelude to an eventual deportation.

Doubts about international protection make fear of repatriation common even among well informed refugees. Some of the educated respondents referred to the controversial repatriation which the UNHCR conducted in cooperation with Djibouti and Ethiopia as a cause of such doubts. Regarding the OAU's capacity to provide protection to refugees from independent African states many of them seem to share Ahmed Karadawi's view that

The refugee problem in Africa is politically motivated and refugees in the form of common groups, or élites, are products of causes which aim at the restructuring of the territorial frame-work of the existing state or conceive themselves as alternative power-élites. With such a background, it becomes evident that any attempt to achieve protection for refugees from an OAU stance is practically far-fetched. The contrary is true that the OAU is more inclined to protect its member states (1982:7).

Feelings of guilt and anxiety about relatives

Social research has revealed that refugees and victims of major disasters in general harbour severe feelings of guilt (Pfister-Ammende 1973; Oliver-Smith,1982). Guilt is felt because of what the disaster victims failed to do or because their lives have been saved at the cost of other's (see Oliver-Smith, 1982:102). Guilt is a negative self-evaluation of a special type which occurs when an individual admits that his behaviour is at variance with a given moral value to which he feels obliged to conform (Kemper, 1978). Among respondents guilt was felt mainly as a result of the failure to meet obligations to which they were bound by filial duties. These were men who left behind their children and wives, and young people whose aging parents were without support. There were also those whose relatives, wives, siblings, offspring and parents were in prison. They felt anxiety and guilt about their situations.

When we asked respondents whether they felt guilty because they had left behind their families or relatives about half answered "yes", and half "no". Some felt guilt because their relatives might have been put in trouble when the authorities discovered their flight. The lack of communication with their relatives made it difficult to resolve the uncertainity and guilt that emanated from this situation. 
Interrelated with guilt we found that about 45 per cent of the respondents were also constantly disturbed by uncertainity about the welfare of their relatives. They believed that something very bad might have happened or will happen to them.

When we asked them what they thought would happen to their families and kin about 24 per cent answered that they might be persecuted by authorities when the respondent's flight was known. Those who left behind their children and wives or old parents (14.5 per cent) were anxious lest their families would be in great distress as they (the bread-winners) had left them without support. About 11 per cent were worried that their relatives might have died without their knowledge. The inability to give decent burials and mourn deceased relatives was disturbing to respondents who traditionally were expected to fulfil such roles. The on-going war and violence in Ethiopia and the consequences for relatives and friends were also causes for anxiety.

Thus the data demonstrate amply that the life of many respondents was constantly impaired by the presence of insecurity and guilt in their minds. What is more, for the tradition-oriented, which many of our respondents are, failure to fulfil obligations and roles like the ones mentioned above caused not only guilty feelings but also shame.

\section{Summary and Conclusions}

An attempt was made to assess the psychological adjustment and acculturation of respondents in the host environment. The results show a low level of adjustment and a slow process of acculturation. Adjustment in the host country was thwarted by economic problems, socio-cultural factors, climate and dietary problems. Cultural and religious differences between the hosts and the refugees and above all the latter's strong desire to preserve their identity and culture were obstacles to acculturation. This and the hope to repatriate when conditions allowed made the development of identification with the host society a very slow process.

Insecurity was widespread among the refugee population. The causes of insecurity were several and differed from person to person and group to group. Many refugees felt legally, economically and physically insecure. Legal insecurity was characterized by a fear of forced repatriation and imprisonment; economic anxiety by a fear of starvation; and physical insecurity by fear of military attack, assault or other forms of hostility from members of the host society or other refugees.

These pervasive fears and anxieties had objective and subjective bases. Some of the 'dangers' that were mentioned as reasons for fear and anxiety were present in the environment, some seem to have been recollected from past experiences and some were apparently imagined. The data show that there were significant relations between fear and reason for flight. Sex, the economic performance of the respondent, the type of settlement and the homogeneity of the immediate environment were found to be associated with fear. Insecurity and anxiety also tend to be frequent even with long residence in the host society. The results regarding the association between sex and insecurity were unexpected and most interesting. In contradiction to the socialization and normative expectations of the society of origin and in spite of the harsh conditions of exile to which they were exposed, women respondents were less insecure. In several cases guilty feelings and anxiety about relatives left behind exacerbated the problem of psychological adjustment in the host environment. 
From the sociological point of view, fear, insecurity and anxiety as expressed above result mainly from real, anticipated or imagined outcomes of social relationships (Kemper, 1978). They result from a negative social relation which is often charaterized by the actor's perceived inadequacy or powerlessness. Recognizing the role of a power deficit in the developement of anxiety Freud wrote that:

On what occasions anxiety appears will of course depend to a large extent on the state of person's knowledge and his sense of power vis-à-vis the external world (Cited in Kemper, 1978).

Flight is in the first place caused by a power deficit. It is a function of the inability "to protect oneself from the insult, injury, inprisonment or death at the behest of others who oppose the self" (Hansen, 1981:190). Changes in the social environment further diminish the power of the individual in various ways.

The exigencies of exile have made a large proportion of male heads of household incapable of feeding their families. In many cases, their role as the family bread provider has been replaced by the agents of the host government or the voluntary agencies who distribute handouts. This is not without impact on the position of the head of the household as his prestige and status is in question. The inability to fulfil the role of provider can lead to loss of control (power) over the family, loss of status and self-confidence.

Refugees experience power imbalances between themselves and their environment in several other ways. When employment is available they often find themselves in very weak positions vis-a-vis their employers. In the Sudan, refugees are not organized in labour unions, and this puts them in a weak position in wage bargaining. Sometimes they are not only underpaid but even refused remuneration. As lonely aliens, refugee labourers lack the language, information, social status and political contacts to challenge their employers in court. In every respect the respondents suffered a debilitating degree of power deficit. What is more, the refugee power deficit is reflected in their lack of participation in decision-making.

Aid agencies are often unwilling to involve refugees when decisions concerning their rehabilitation and their future are made. This is a clear reflection of alienation and marginalization. Perlman noted that

Marginals do not share in the responsibilities and assignments that must be undertaken for the solution of social problems in general, and their problems in particular (1976:121). 


\section{PART IV}

\section{SUMMARY}





\section{Chapter 10}

\section{Summary and Policy Implications}

Whether voluntary or forced, migration is a process that has different stages and multiple causes. It is common among researchers to study only one stage of the process. In the case of forced movements across international borders, the phase that is often studied is the destination - what happens in the country of asylum. Even here most studies seldom strive to get a holistic view but focus only on one or two aspects of the problem. What is more, refugee studies are almost always limited in space and time. In Africa, refugee studies tend to examine the conditions of a specific group and comparisons are seldom made between different categories of refugees even when they originate from the same country.

In this study our approach was different. By putting the problem of uprooting in a historical perspective we have attempted to unveil the links between the past and current events that produce conflicts and spur mass exoduses from Ethiopia. We have followed the study population across space and time and attempted to document and analyze their experience at the various stages of flight. Our point of departure was the assumption that the refugee phenomenon as a sociological problem could be understood better when and if related to the macro-sociological and historical processes in the society of origin. This is because conflicts that produce refugees are rarely random but interwined with the historical development of society and its structural elements, as well as with the international historical processes that intersect with domestic processes.

The above is the case at least in Africa. Colonialismand the struggle against it have produced refugees in most of the African countries. Even after the dawn of independence most of the refugee flows in Africa have their roots in the colonial history of the continent. This study has attempted to show that the current conflicts and mass uprooting in Ethiopia have their roots in the historical processes that created the Ethiopian Empire at the end of the last century. Our conclusion from the historical analysis presented in Chapter 2 is that the majority of the nationalities in today's Ethiopia did not escape the colonial experience. But as with most countries in Africa, Ethiopia's boundaries were drawn during the scramble for colonies, in which Abyssinia was a participant.

Although the various peoples in the Ethiopian Empire were colonized by the neighbouring Abyssinians, the European powers of the day were also actively involved in the Abyssinian expansion. The Abyssinian domination over conquered territories had most of the characteristic features of colonialism. The conquest, which took about three decades to accomplish, was violent and involved mass killing, large scale destruction and pillage. Begun with such violence, the occupation of the Oromo, Sidama, Somali and Nilotic territories was sustained through repression. Ketemas or colons were established in the classical colonial fashion in these areas. The Abyssinians who settled in the ketemas lived more or less separated from the 
indigenous people for reasons of security and comfort and did not integrate into the indigenous social environment.

The administration of the conquered areas was very similar to that of the European colonialists in the neighbouring territories. The political institutions of the conquered peoples were suppressed and replaced by an Abyssinian administration. The Emperors relied upon personnel derived mainly from the Arnhara people to administer and control the peoples in the peripheries of the empire. The kings and chiefs of these areas were eliminated. Those who submitted to the Amhara without resistance were mainly reduced to balabats who functioned as go-betweens for the colonial administration and their subjects. The suppression of the organizations and cutures of the non-Abyssinian peoples was made the modus operandiof the Amhara domination.

Sociological research has identified two elements common to the ideologies of all forms of colonial domination. The first is the justification of conquest as a benefit to the conquered. The second is the declaration of the superiority of their culture to that of the conquered society. It is also quite common that conquerors try to assimilate the conquered. This is often done on a selective basis whereby the conquered ruling classes are co-opted into the conquering class. Sometimes the cultural assimilation of the entire society is also attempted by conquerors (van den Berghe, 1975). Menelik emphasized that the conquest was a sacred civilizing mission to impart the benefit of Christian rule to heathen peoples. His successors emphasized the inferiority of the non-Abyssinian languages and cultures and their use was discouraged or even forbidden. The Amhara language and at times the Abyssinian Coptic Christianity were imposed on the indigenous peoples. Nevertheless, the Amharizationeffort met with little success. In this study we have identified three factors as the reasons for this lack of success. To begin with, the effort met with considerable resistance from the targeted peoples. Secondly, there was a lack of resources for the implementation of the Amharization. This was particularly the case with the expansion of education as the main vehicle of assimilation. Few schools were built in the conquered regions. What is more, few non-Abyssinian children had the opportunity to attend school even where it did exist in their areas. The third and most important factor was the contradictions and paradoxes that characterized the naftanya attitude towards the Amharization of their subjects. Amharization undermined the interests of the naftanya and their state because it was convenient to exploit the non-Amhara when they were non-Christian. The conversion of the subject peoples in the peripheries of the empire to Christianity provided them with a chance to escape from the worst aspect of the occupation: enslavement (Donham, 1986:44). The Coptic Church forbids the enslavement of Christians. Furthermore, Amharizationalso meant the promotion of these peoples to political equals with the naftanya. Thus the assimilation of the subject peoples could only have weakened a structure which benefited the settlers socially, economically and politically. This was certainly not the wish of the settlers or their rulers. Therefore, whatever effort was made to Amharize the subject peoples during the previous regimes was unconcerted and unsystematic.

Economic gain was the prime motive force behind the Abyssinian colonial expansion. Their mode of surplus extraction from the subject peoples differed considerably from that used by European colonialists in the neighbouring territories. In this study we have identified three such methods: looting, slavery, and the gabbar system. 
During the earlier phase of the occupation, property looting and slave trafficking constituted the main methods of exploitation. Slavery affected the conquered peoples in varying degrees. The hardest hit were the Nilotic and Sidama peoples who were captured and sold in large numbers.

The gabbar system affected mainly the Oromo and Sidama peasantry. The system was built on the confiscation of land from the indigenous peoples. The emperor, the nobility, the Coptic Church, soldiers who participated in the conquest, Abyssinian migrants who went to the south following the conquest and Abyssinian refugees from the 1889-92 great famine became owners of the confiscated land. The indigenous peasantry became gabbars on their own land and were distributed among the settlers.

The obligations of a gabbar to the settlers who owned the land he cultivated resembled the obligations of both a serf and a chattel slave to his lord and master. $\mathrm{He}$ paid as much as 75 per cent of his produce to the naftanya. The gabbar was not totally free to leave the service of his "patron" when he wanted. In addition the naftanya could utilize the labour of his family almost as if they were his slaves. But the naftanya did not have the responsibility for feeding, clothing and housing as the slave owners did. What is more, obligations to the state and the Coptic Church in the form of cash, kind and labour made the burden of the gabbars onerous indeed.

The rifts between the Abyssinian minority and the conquered peoples along lines of culture, language and religion were wide and deep. These differences were superimposed upon cleavages in political rights and economic privileges. Thus society in imperial Ethiopia was divided into rulers and subjects, oppressors and oppressed along ethnic lines. Little effort was made under either Menelik or Haile Selassie to transform the empire into a united country. The peoples in its peripheries remained hostile to the Amhara state and its agents. The rulers used naked force to quell resistance. Nevertheless, the regulation of subject peoples with the force of arms had only a limited effectiveness. It did not achieve more than temporary calm as the subject peoples did not accept the Amhara domination as legitimate.

Consequently, government troops have been engaged in the pacification of rebellious subjects ever since the creation of the Ethiopian empire. However, the intensity and duration of conflicts varied from place to place and from one period to another. The most persistent resistance was staged in the south by the Oromo and the Ogaden Somalis. In the north, the Eritrean liberation movement has been the most active oppositon over the last twenty years.

The long-standing effects of these conflicts, the structural crisis in the economy together with various short-term factors such as drought and inflation led to a popular uprising in 1974. The military council which took power following the demise of the ancien régime promised radical political and economic reforms. Socialism was declared as the state ideology. A radical land reform was proclaimed. Private firms, banks, insurance companies and urban houses were nationalized. The regime also declared the abolition of all forms of inequality between the different nationalities in the empire state.

The contradictions between the policies and the actions of the new regime were considerable. The revolution did not lead to the political or cultural autonomy of the oppressed nationalities. Although the raison d'etre of the 1974 uprising was the fair distribution of power and privileges among the various groups in the country, these became even more concentrated in the hands of the Amhara elite than under the 
previous regime. The non-Amhara nationalities won little ground in cultural and linguistic rights. In fact Amharization was intensified, shrouded in projects and programmes like resettlement and alphabetization. The lack of sound plans and the diversion of resources to warfare led the country into economic catastrophe. The land reform which was the most radical change resulting from the revolution failed to lead to improved life conditions in the rural areas. Various factors such as the mass conscription of productive labour to the militia, taxes which were as onerous as the feudal dues under the former regime, and the Dergue's marketing policy concerning agricultural products became major constraints on production. The standard of living deteriorated considerably and mass starvation and death from famine became a persistent reality. The country's dependency on international aid increased tremendously as its capacity to produce its own food dwindled. Millions of Ethiopians stay alive today only because of humanitarian aid from outside.

The militarization of the economy affected equally the urban population. Nationalization of industries did not result in the improvement of the conditions of the labourers. Wages stagnated in spite of a staggering increase in the prices of basic commodities. Public investment was adversely affected by the allocation of capital to military expenditure. The expansion of unproductive administrative and propoganda activities at the cost of productive enterprises meant a tremendous increase in the rate of unemployment in the urban areas. In the absence of industrial development the only source of employment for the tens of thousands of youngsters who completed their secondary education every year was the military, with the prospects of early death in the wars against dissident nationalists.

Haile Selassie wiped out some nationalist leaders and rewarded and co-opted others into the dominant Amhara-Tigray group to rule the multi-ethnic empire. In its relations with the opposition the Dergue proved to be more respressive than its predecessors. It attempted to solve all political problems by the use of force. However, repression seldom induces voluntary support or compliance. Therefore, the polarization between the state and the oppressed nationalities was accelerated.

The forceful propagation of what Markakis (1984:356) called "state nationalism" by the Dergue provoked dissident nationalism that was articulated and led by the educated Clites from the non-Amhara nationalities. These Clites were able to organize and arm large armies of politically conscious and motivated guerrilla fighters. They were also able to create social, economic, educational and health programmes in the areas they controlled. Thus the opposition that the Dergue faces today is numerically and qualititively different from that which faced Haile Selassie during his long reign. Haile Selassie won total victory over the Woyane revolt of the 1940s and was even able to suppress the Oromo and Eritrean uprisings in the 1960s. Today the Dergue commands a much larger force and has an enormous supply of weapons. However, it has failed to subdue the mounting opposition in the various corners of Ethiopia.

The continuing polarization between the regime and the non-Amhara nationalities has also meant the extensive use of repression against a very large section of the country's inhabitants. The state apparatus of coercion and repression have been expanded enormously to meet the mounting opposition. The armed forces have increased more than ten times in size since 1974. Because of the denial of civil liberties the society has been under a permanent state of siege since 1974. 
With the declaration of the "Red Terror" in 1977, the Dergue opted for state terrorism as a legitimate policy to control its subjects. Stohl and Lopez (1984:8) have suggested that oppression, repression and terrorism can be carred out by states as concurrent and coordinated policies and actions. They have, however, pointed out that terrorism is a very special act of state violence and behaviour. The terror act aims not only to eliminate active opponents but is also meant to carry a message of intimidation directed against the audience whom the perpetrator seeks to control. Stohl proposed that "the legitmacy of the national state is itself normally conceived as providing legitimacy to actions that would be condemned as terrorism if such behaviours were executed by non-state actors" (1984:43). These observations hold also for the Dergue's "Red Terror".

Although the worst period of violence as characterized by the instantaneous execution of suspects came to an end in 1978, state terrorism continues in Ethiopia. Elements of such terror are manifest in the implementation of the resettlement and villagization programme and the regime's numerous military operations which often affect civilians. Such terror and violence have spurred involuntary migrations of an unprecedented scale. During the last ten years nearly two million people have sought asylum in neighbouring countries. At present about 50 per cent of Africa's refugees originate from Ethiopia. The Sudan, with about 900,000 refugees from Ethiopia, is the largest recipient of these asylum seekers.

This study shows that those who have sought asylum in the Sudan originate from a wide spectrum of ethnic, social, economic and cultural backgrounds in Ethiopia. The causes of their uprooting have also varied considerably. However, violence and fear of violence have been the major motives for flight in the majority of cases.

We developed a tentative typology of refugees and forms of their displacement in the theoretical section of this study. Using this typology we were able to identify five broad types of refugees in the study population. The first type consisted of political activists. The majority of this type were connected to or sympathized with the various nationalist movements operating in Ethiopia. All originated from urban backgrounds and had at least completed elementary school. Almost all of the respondents with university education also belonged to this category. Actual persecution or fear of persecution during the "Red Terror" and the subsequent years was the main cause of their flight. The second type consisted of officials of the former government and members of land-owing class. Their flight was the result of loss of property, position or privileges and the danger to their lives entailed by the outbreak of the revolution and the subsequent political development in Ethiopia. Therefore, they constitute a category of refugees which can be perceived as a direct result of the revolution. They originate both from urban and rural backgrounds.

The majority of the respondents fall under the third type: the displaced masses. The respondents in this category did not originate from similar social, class or economic backgrounds. The majority were peasants. But some were agropastoralists and farm labourers. The large majority left their country under acute situations caused by the horrors of war. Some left because they anticipated danger. There were also those who fled as a consequence of the destruction of their property, the disorganization of social life and the breakdown of economic production as a result of war. This is relatively common in areas where the Dergue is said to have used the "scorched earth" strategy to "discourage" the peasantry form assisting guerrilla fighters. The displaced mass category includes also individuals who fled because of 
famine. Flight, even when famine is seemingly its cause, reflects relations between the people and their rulers. For example, during the 1973-74 drought the victims did not flee across international borders. But in 1984-85 about 150,000 people crossed into the Sudan. It would be wrong to perceive this mass exodus as the result of drought and the availability of aid in the Sudan, as is often done. The flight is mainly accounted for by political conditions that hindered access to food relief in Ethiopia.

The uprooting of the fourth type of refugees differed considerably in its causation from the classical type of flight. It was not the result of direct persecution or the outbreak of war but of the consequences of policies that were overtly "rehabilitative" and "developmental". After the displaced masses, refugees in this category are the largest group from Ethiopia. The majority of these were escapees from resettlement schemes and state farms. The approach in the implementation and administration of such projects is state-centred and recognizes the priority of the state interest over that of the people that are said to be rehabilitated, or for whose benefit the programmes were said to have been designed. The implementation of such projects often involves intimidation and naked force. Flight is the reaction to the use of such force. It also represents an inability to cope with the hardship and the social disruptions which the coerced participation in the projects entailed.

The fifth type were respondents whose reasons for uprooting fell between refugees and voluntary immigrants. Their motives were considerably diversified and often ambiguous. Several sub-categories were identifiable in the group. There were respondents who joined the exodus under the pressure of the social force and flight psychosis that obtains in mass flight situations. Others were pushed out by the feeling of asphyxia that was created by the perennial siege constituted by the omnipresent armed militia and the permanent curfew and the numerous security checks and control all over the country. This category also includes those respondents who came to the Sudan to join their families, were in search of relatives or just followed their peers. There were also individuals who joined the stream with the intention of looking for better opportunities abroad. The conclusion that flows from the study of the causes of the uprooting of the respondents is that flight, like voluntary migration, can also create chain migration. Such a chain contains individuals and cohort groups with considerably diversified motives. Chain migration can persist long after the danger that triggered off the earlier movements has tapered off.

Although the major force behind every exodus is an unfavourable socio-political environment, the results of this study indicate that it is only a minority of those who are affected by such changes who decide to flee. The decision to flee is reinforced or counteracted by sociological, psychological and geographical variables. In the majority of cases covered by this study, the decision to flee was most influenced by distance from an international border. The empirical analysis showed that the flight rate decreased markedly with increasing distance from the border.

Another conclusion that emerged from the study of the flight dynamics of the sample population was that the distance covered by an individual or group in flight between the point of departure and settlement is a function of demographic characteristics. Thus respondents with rural backgrounds in general fled shorter distances than those from urban areas. Their flight tended to consists of single-step movement as they often chose to stay at the first point of safety. However, the reasons why respondents with rural backgrounds preferred to settle at the first point of safety do not support the commonly held assumption that African refugees concentrate in the 
border areas because of ethnic considerations. It is often socio-psychological factors and practical problems which limit rural refugees to border areas.

Urban refugees risk longer journeys to reach safety than rural refugees. They do not stay at the first point of safety but move further into the interior of the country of asylum. Persons with higher education often travel further to reach their final destination than those with lower education. In the Sudan the final destination is often Khartoum, from where most refugees try to re-emigrate to other countries.

Since they are triggered off by the urgency of the situation refugee movements are generally not preceded by preparation and deliberate choice of destination. This is evidenced by the flight of the persons covered in this study which in most cases was characterized by panicky departure rather than deliberation and calculated action. And this had its consequences in the course of the flight. The majority encountered pitfalls and experienced hardship on the way. The most serious dangers encountered were armed robbery, assault and rape. Moreover, the majority of the respondents experienced serious hardship emanating from lack of food and water, illness, pregnancy and child birth.

The hardships often do not disappear or even decrease immediately after arrival in the host country. Nine out of ten respondents encountered serious subsistence and shelter problems particularly during the early phase of their sojourn in the Sudan. Ill-health was widespread because of physical exhaustion, the change of environment and malnutrition. Consequently, the death rate among those who stayed in the remote border areas was high. The lack of access to humanitarian assistance also made the initial adjustment of this group difficult.

The main focus in this study was on the problem of refugee integration in the socio-economic environment of the host society. Integration is conceptualized as a long-term process. The rate and direction of integration is perceived as a function of the interaction of the variables prevailing prior to flight and the situational variables in the host environment. We have examined the process from the economic, social, cultural and psycholgical perspectives.

Employment and income were used as the main indices of economic absorption in the host environment. The empirical investigation showed a high incidence of under-employment among the study population. The majority depended primarily upon seasonal wage-labour provided by the commercial farms and casual employment in the informal sector. The average annual rate of employment for the study population was about seven months. Only a minority of the respondents had jobs of a permanent nature. The economic activities in which the majority of the households were engaged brought in very low incomes. Hence, only about 10 per cent of the households had achieved economic self-sufficiency after an average of about five years residence in the Sudan. About two-thirds earned average annual incomes below subsistence levels. The incidence of absolute poverty was such that about 40 per cent of the households spent nearly 100 per cent of their total income just on food. But they still existed on the verge of starvation and malnutrition.

As the consequence of the interaction of malnutrition and overcrowded living conditions, there was a high morbidity rate among the respondents' families. Tuberculosis was a common disease in nearly all of the settlements. The dysfunctional links between these deficiencies tended to perpetuate the social and economic deprivation of the refugee households.

Poverty and malnutrition lead to ill-health which in turn depreciates the capacity 
of individuals and households for economic production and the improvement of living conditions. Such a vicious circle of poverty is rather a common phenomenon affecting the poor in Third World countries (McHale and McHale, 1977; Chambers 1982). However, the social and economic disorganization and disorientation resulting from uprooting accentuates the problem among the refugees.

The findings in this study show that social and economic deprivation is relative even among refugee populations. Absolute poverty, although very common, is not the fate of every refugee household. A significant proportion of the respondents had succeeded in satisfying their basic needs through their own labour. Some had even achieved a satisfactory level of economic self-sufficiency according to the criteria spelled out in this study. A minority had acquired a standard of living which they considered to be much better than that they had had in Ethiopia. The achievement of economic self-sufficiency was associated with a variety of sociological variables and situational determinants. The rate of employment and income were significantly relationed to the sex, educational background, the place and type of settlement of the respondents.

The sex of the head of household showed considerable association with the level of economic integration in the host environment. One of the consequences of uprooting is the breakdown of the family and other forms of social organization. The incidence of family disorganization among the study population is evidenced by the frequent occurrence of households headed by women. The results of our study show that about 15 per cent of the households covered had female heads of household. The proportion of female respondents who were defacto heads of household is twice that if we consider families whose male heads were constantly away from home either working in other countries or engaged in the guerrilla war inside Ethiopia. The rate of unemployment was one and a half times more frequent among female-headed than other households. The proportion of female heads of household earning income below subsistence level was greater than among men. Conditions obtaining prior to flight and in the host environment interact in rendering female-headed households the least viable in terms of achieving economic self-reliance. These households were also socially the most vulnerable among the community of vulnerables. In most of the societies in Ethiopia men are responsible for the livelihood of their families. Although they participate in economic production, traditionally women seldom assume the role of the household bread-winner and decision-maker. Consequently few of the female heads of households in the study were vocationally or psychologically prepared to shoulder the responsibilities which uprooting forced upon them. This handicap is exacerbated by the host society's culture and traditions. The religious values of the Islamic Sudanese society discouerages the active participation of women in economic production and confines them to the home. Even when the refugee family is headed by a male, the confinement of women to the home curtail considerably the capacity of the household to achieve economic self-sufficiency. The negative effect of uprooting upon women is profound also in the sense that their traditionally disadvantaged position in the family and community power structure is exacerbated. However, we must be cautious not to generalize these findings to the conditions of refugee women all over the world (cf. Christensen, 1982:36).

There are also other social structural variables that tend to put limitations upon the capacity of households to achieve economic self-sufficiency. Thus the length of employment was longer and average income higher among respondents with school 
education than those without such backgrounds. Those with higher education were generally employed for longer periods than those with lower education. The relationship between occupation and economic self-sufficiency is strong. Agricultural occupations, whether subsistence farming or wage-earning provided the least possibility for self-reliance. The relatively permanent semi-professional and clerical occupations followed by handcraft and catering jobs provided the best possibilities for economic self-sufficiency. This findings suggest the need for the diversification of activities and sources of income. Our conclusion is that agricultural activities in the settlements should be supplemented by other income generating activities to help refugee households achieve economic self-reliance.

The incidence of absolute poverty also varied considerably between the types of settlements. In general, the urban setting tended to offer better opportunities than rural settlements. The proportion of households falling under the existence minimium level was twice as high in the rural settlements. Households that had achieved economic self-sufficiency were three times as many in urban settlements than in the rural settlements. Differences were also observed between sub-categories of rural refugees. The highest rate of the incidence of absolute poverty was found among self-settling groups, followed by those living in organized wage-earning settlements.

One of the perturbing findings of this study is the lack of relationship between the length of time spent in exile and improvement in the material standard of refugee households. The incidence of material poverty was as frequent among those who have been in the Sudan about six or seven years as those who had been there just a year or two. This contradicts the assumption underlying refugee aid planning in Africa. In the plans of host governments and international agencies the achievement of satisfactory economic self-reliance by rural refugees is usually envisaged within a period of four or five years. Such projections are usually made to determine dates for the withdrawal of humanitarian and development assistance. The findings in this study clearly indicate prolonged dependency.

The causes of poor economic performance and prolonged dependency are complex. In the Sudan, it arises primarily from the unfavourable economic conditions. The Sudan is one of least developed countries in the world. Its underdeveloped economic infrastructure is hardly capable of absorbing a massive influx of destitutes within the space of four or five years. What is more, the Sudan has, in recent years, experienced severe economic set-backs. These were exacerbated by a devastating drought in 1984-85. The lack of business licences to resume vocations abrupted by flight, restrictions upon movement, insecurity and language problems were some of the other host country factors that constrained the refugee household's productive capacity.

The self-sufficiency of refugee households was, in some respects, also counteracted by uncertainty about the future. Most of the respondents saw their presence in the Sudan as a temporary one. And some of them were not prepared to make the maximum effort to establish themselves economically. These refugees were satisfied if they could acquire the means for survival. Nevertheless, such a mentality was limited to a few individuals in the sample and should not be generalized to the whole population. In fact, the majority were hard working people. Enterpreneurship was not lacking. Although most were in petty trade and other marginal economic activities, a large proportion of the study population was self-employed and struggling to make the best out of their situation. Some of them were even able to create 
job opportunities for others. Work permits and the lack of starting capital were also some of the constraints on economic self-reliance. Exploitation by employers and house owners was not uncommon.

The results of this study showed weak internal and external social integration among the study population. However, the degree of social integration varied considerably between different refugee groups. By internal social integration, we mean social relations and organization within the refugee community. External social integration concerns host-refugee relations. As a consequence of uprooting, households with an abnormal social composition were prevalent in the settlements. Relatively high divorce rates, missing spouses and the high frequency of single parent families indicated that family organization was weak in the refugee communities. Although family disorganization resulted mainly from uprooting, economic conditions in the Sudan were also contributory factors. Even when the family structure was relatively complete the male head were often away at work elsewhere in the Sudan or in another country. In a foreign environment, this constituted a considerable social and psychological stress for the family. The refugee households, and by extension the refugee communities in some of the sample sites, were also weakened by the out-migration of the young and healthy members in search of jobs and education elsewhere.

When assessed by the rate of participation in voluntary organization and the incidence of social conflict, the study population showed a low degree of secondary social integration. This was, however, not universal to the population. Considerable differences were observed between the two patterns of settlement. The rate of participation in voluntary associations was three times as frequent in the spontaneous settlements as in the organized ones. Group cohesion and solidarity was more developed among self-settlers than those in the organized settlements. The differences seem to have emanated partly from how the humanitarian programmes operated, and partly from the social structure and the economic opportunities in the organized settlements. Although "participation" or "helping the poor to help themselves" has been the theme of development literature and seminars for more than two decades, it is not yet much practised by aid agencies and government authorities working with refugees in the Sudan.

Lack of organization can also be attributed to the lack of economic opportunity in the settlements. Large proportions of the inhabitants were absent from home working or looking for work somewhere else. The consequences of such absence considerably curtailed social interaction. The development of relations was obstructed particularly in the organized settlements. Although the organized settlements had been established for several years, our study showed that some communities lacked functional structures for leadership, social control and conflict resolution. For the refugee community the emergence of its own leadership capable of promoting their interests vis-à-vis the hosts, government officials and humanitarian organizations is crucial. It is also the sign of internal integration.

Sociological theory suggests that social order exists when an entire community or society for a significant part of its history is characterized by a distinctive pattern of social organization (Broom and Selznick, 1968). The results of our study show that the settlements with the lowest rates of participation in voluntary associations also had the highest incidence of refugee-refugee conflict.

The causes of refugee-refugee conflict were varied. Some of these are structural 
and closely related to conflicts in the country of origin, such as the political differences, ethnic and religious factors found to be behind the animosities among refugee groups. However, the major cause of conflict among refugees was the exile situation itself in its social and psychological effects. Idleness and frustration were common phenomena because of unemployment and underemployment. They were found to contribute to most of the refugee-refugee conflicts. In general, the incidence of social conflict was more frequent among the refugees themselves than between them and their hosts.

The degree of integration of the study population in the Sudanese society was low. Social interaction between the refugees and their hosts was limited. At the primary level only a minority of the respondents had managed to establish interpersonal relations and friendships with their hosts. The rate of inter-marriage was negligible. None of the subjects in this study belonged to host voluntary organizations.

Linguistic problems, the pattern of settlement and cultural and religious differences accounted for the low rate of social integration in the host society. In the majority of cases the lack of functional Arabic impaired interaction. This has among other things contributed to the low rate of primary social relations with the hosts. Interaction between the refugees and the host community was also influenced by the pattern of settlement. Organized settlements, which were often segregated spatially from the host community had a negative effect upon social interaction and integration.

Integration in the host society was countervailed by the perception of the refugee problem as transient. The lack of provision for the naturalization of exiles in the Sudanese Asylum Act suggests that the host government views the refugee presence as temporary.

Few Sudanese seem to be willing to enter into partnership with refugees because of their political and perhaps also social status. For the same reasons Sudanese voluntary organizations, including the labour unions, do not seem to be ready to accept refugees as members.

The perception of life in exile as transient is positive. It is a hope that most refugees do not like to lose. Besides, voluntary repatriation is the optimal solution to any refugee problem. However, when the date for repatriation is apparently remote as is the case for the subjects of this study, such a perception constitutes an obstacle to economic self-reliance and social integration in the host environment.

The best policy, according to our view, is that which treats refugees as if they were permanent residents, accords citizenship to those who want to take it and tackles their problems within the framework of the national development programme. International organizations and host governments often conceive integration as an economic process. Refugees are perceived as integrated when they achieve economic self-sufficiency. But until they feel legally and socially secure it is difficult to see them as integrated in the environment.

The general attitude of the Sudanese towards refugees is generous and accommodating. Sudanese hospitality to strangers seems to be the result of centuries of migratory movements within and across the country. It stems also from the religious belief in helping the unfortunate and the homeless which is strong in Islam. Nevertheless, the results of this study showed that the hospitality, generosity and solidarity which refugees meet in the Sudan were sometimes mingled with hostility, exploitation and aggression. 
The conflicts between respondents and their hosts were often expressed openly but they seldom reached a level of widespread violence. Often these conflicts had objective material and cultural causes. The massive refugee influx is a heavy burden upon the fragile economy and infrastructure of the Sudan and is felt most by the poor classes in the Sudanese society. The influx led to competition for scarce job opportunities. Sometimes the situation was exploited by employers and wages were decreased while prices and rents increased enormously. No doubt that the survival of the Sudanese poor will be threatened by these circumstances. Consequently there is growing resentment of refugees in some areas with large refugee concentration.

The reasons for host-refugee conflicts were not limited to the economic sphere. Religious and cultural differences also caused incompatiblities regarding social values. Christian refugees had values which conflicted with their hosts regarding the use of alcohol and to some extent the role of women in society. These incompatibilities often caused open conflict between refugees and the Sudanese.

The incidence of host-refugee conflict varied considerably between the study sites. Its rate was high in the spontaneous urban settings, medium in the organized settlements and very low in the spontaneous rural settlements. In general it was associated with the proportion of refugees in the population of a given area. Thus Gedaref, which was one of the areas with the most dense concentration of refugees also had the most frequent incidence of host-refugee conflict. Yabus and Muguf with a comparatively low refugee influx had no conflict experience.

The level of acculturation was low in every respect. Given the cultural and religious backgrounds of the respondents and the length of residence in the Sudan this was what we would expect. The only area where a considerable degree of acculturation was noted was language learning. But even here it was only a minority who had acquired a functional knowledge of Arabic. The demands for conformity from the hosts have brought about some changes in behaviour and clothing. The changes were passing mechanisms adopted to avoid problems and gain acceptability. Considerable changes in eating habits were also made as the result of the lack of familar foods. Although conversion to Islam was rare, self-settlers quite frequently adopted Arabic names.

Socio-psychological studies have shown that the coping strategy commonly adopted by uprooted people in alien enviroments involves clinging to the familiar and making no more changes than necessary for survival (Scudder and Colson, 1982:272). This conservative stance is most often adopted in the area of culture. The maintenance of ethnic and cultural identity becomes a preoccupation when the socio-cultural differences between the societies of origin and asylum are great. The importance given to the preservation of their religion, which is threatened by Islam, was demonstrated by the strong adherence of the study population to christian values and practices. In some of the organized settlements the only voluntary activity that brought the inhabitants together was their religion.

One of the aims of this study was to assess the socio-psychological adjustment of the subjects in the host environment. The interview results showed that insecurity and anxiety were widespread in all of the sample sites. The fear of forced repatriation disturbed a large proportion of the subjects. The possibility of armed attack worried those who lived in the border areas. Assault and other forms of hostility from their hosts or fellow refugees were feared mainly by those who lived in Gedaref, Tawawa 
and Um Gulja. Economic anxieties and the fear of starvation were felt among self-settlers.

The results of our analysis demonstrated that these fears and anxieties had both objective and subjective bases. Most of the fears mentioned emanated from the problems existing in the immediate socio-economic environment. Some of them were recollections of past experiences and were projected on to the present surroundings. Host-related anxieties partly reflected the increasing incidence of hostrefugee conflicts. These anxieties were also the result of a lack of contact and comprehension. The social environment in the organized settlements was another Cause for insecurity. Most of the respondents had never lived among large numbers of strangers.

As strangers the refugees did not trust one another. The social disorganization and conflict that characterized these settlements exacerbated this paranoid feeling.

Fear of forced repatriation resulted from a lack of information about the existing system of international protection and the asylum policies of the host government. But it was also a reflection of how the respondents viewed the authorities. Over the generations, people in Ethiopia have learned to obey but not to trust those who have power. They'have always been powerless in their relations with their rulers. This feeling of powerlessness does not disappear in a short period of time, even when there is no danger of forced repatriation.

Respondent anxiety concerned not only their own security but also that of relatives left behind in Ethiopia. The lack of contact with their families and relatives exacerbated respondent worries regarding their welfare. The guilt feelings that studies on refugees all over the world have revealed were prominent in causing the psychological stress observed among the respondents.

In general, social and economic marginality characterized the conditions of the study population. Here marginality denotes lack of participation in the important sectors of the host socio-economic systems. Few of the respondents belonged to the regularly employed labour force. A large proportion of the study population was employed in marginal occupations in the informal sector. Those who were employed in the formal sector were only precariously attached to the labour market as seasonal agricultural wage labourers.

Social marginality was most evident in the organized settlements. The inhabitants of these settlement lacked internal social cohesion and organization so that social strife was frequent. Hostility and suspicion rather than cooperation and solidarity marked social relations. The government-organized refugee communities were also isolated from the large society. Since they were spatially segregated from the local communities, contacts and interaction with the Sudanese were minimal. The spatial segregation and social isolation acted as impediments to socio-cultural integration. Few of the respondents in the organized settlements were able to pick up Arabic or had adopted Sudanese culture.

The one area in which the organized settlements have been clearly successfulwere in the provision of social services. All the settlements covered had their own schools and clinics. In some of the settlements, assistance to vulnerable households and individuals was available. Medical services for tuberculosis patients were provided in all of the settlements. Apart from the lack of water in some places, the assisted refugees enjoyed even better services than the local population. 
The results of this study have several policy implications. We shall mention here just a few of them.

The political situation in Ethiopia continues to manifest increasing conflict between the government and the opposition. The economic crisis facing the Ethiopian society is deep and persistent. In view of these conditions it is reasonable to assume that the date for voluntary repatriation is remote. In the meantime, the logical solution to the refugee problem discussed in this study is integration in the country of asylum. In order for the refugees to integrate into the host society and achieve self-reliance the following steps must be considered.

The economic capacity of the Sudan to absorb the refugee influx must be strengthened by initiating short- and long-term development projects that can benefit both refugees and the Sudanese. The relationship between refugee aid and development has been recognized by the UNCHR and researchers, but is not yet widely practised. In the Sudan, with Africa's largest refugee population, there is an urgent need to translate the concept into practice.

The exclusion of refugees from the decision-making processes that concern their lives constitutes a severe constraint on their integration in the country of asylum. Self-reliance requires the full involvement of refugees in the decisions that affect them. This is a common view among most of the scholars who have conducted development research in refugee communities. In the Sudan there is a need for the promotion of refugee particpation at every level of the decision making process. Refugees should be encouraged to create their own organizations, to elect their own representatives and be allowed to run their own affairs wherever they happen to settle. The social apathy and disorganization which we have observed in some of the organized settlements can only be counteracted by promoting the organizational resources and capacities of those communities. The process of delivering relief assistance should not damage the refugee skills and resources that are crucial to long-term rehabilitation.

Insecurity was found to be socially, psychologically and economically harmful to refugee integration in the Sudan. Anxiety about forced repatriation was particularly widespread among the study population. This anxiety must be counteracted by providing refugees with basic information regarding their status, their rights and their obligations as residents in the host country.

The seasonality of employment makes agricultural activities insecure sources of livelihood in eastern Sudan. Agricultural settlement whether on a wage-earning or family plot basis was found to be the least viable strategy for economic self-reliance. Hence there is a great need for the expansion of income generating activities. The study showed that petty trade and casual employment were some of the sources of supplementary income used by refugee households during the times of hardship. This type of survival strategy often involves movement outside the rural settlements. Government policies regulating freedom of movement should take this into account.

The continuing influx of refugees from Ethiopia will, no doubt, constitute a major constraint on the socio-economic development of the refugee settlements in eastern Sudan. More refugees will naturally mean more resources for relief and less for long-term investment. This will also engender increasing resentment from the local population. Therefore, there is a need to address the causes of the problem at their source, in the country of origin. As we have seen, refugees are mainly the products of the violation of some of the basic human rights. The problem is exacerbated by the 
role of the super-powers. By supporting repressive regimes and supplying weapons to parties in conflict they contribute seriously to the problem of mass displacement. This makes the cause of refugee influx a complicated issue to deal with. However, it is an issue that must be addressed, by social researchers, policy-maker and international organizations. Humanitarian and development assistance cannot be the lasting solution to the Ethiopian refugee problem if it continues to increase at the present rate. The problem must be viewed in all its complexities and challenged on a broader front. 


\section{Notes}

\section{Chapter 1}

1. Since 1979 Somalia, a country with about 3.5 million inhabitants, has hosted between 800,000 and 1.5 million refugees. Djibouti, with its tiny population of about 250,000 , has at times sheltered about 50,000.

2. Many of the African states faced severe lack of trained manpower upon independence because the colonialists did not train Africans inspite of their presence in these colonies for more than half a century. In some of the colonies there were less than a dozen university graduates on the eve of independence.

3. It was estimated by the UNHCR that 500,000 refugees had spontaneously returned in 1981 from Somalia to the Ogaden in Ethiopia. The estimate is based on reports from the Ethiopian government and not on the report of the UNHCR or that of any other neutral body. This and the inability of the Ethiopian regime to control theinflow and outflow of the nomadic population across the vast borders of the Ogaden, make the above figure very unreliable.

4. For details of the basic socio-econom facts on the Sudan see Francis A. Lees and H.C. Brooks, 1977, ILOIUNHCR Report, 1984 and World Bank annual reports.

\section{Chapter 2}

1. It should be clear to the reader that the aim of our brief historical sketch over the formation of the Ethiopian Empire and the nature of the state is not to maintain that unity between the various peoples is impossible and undesirable but to the emphasize national oppression and the inequalities which are seedbeds of conflicts.

2. See for example Challenge, X1, 1(1970) where Endreas Eshete in an article titled "The Problem of Regionalism and Religion: some Theoretical Considerations", writes: "Colonization even in a primitive form requires manufacture production. In its purer forms, it demands industiral production and capital. Certainly, feudal Ethiopia did not possess any of the prerequisites which were components more advanced stages of social and economic organization. With feudalism, one can speak of conquest not colonization ..."

3. See Combat (A Political Pamphlet issued by Ethiopian Students' Union in North America - ESUNA), Vol. 2 (1976) P.iv.

4. Mohammed Abdulla Hassan fought against the British and the Abyssinian forces between 1895 and 1920 in the Ogaden and British Somaliland. The following expeditions were joint Anglo-Abyssinia attempts to liquidate his forces 1900-1904.

a. November 1900: British Army - 1500 men, Abyssinia army - 15,000.

b. June 1902: British army - 200 men, Abyssinian forces - numbers not given.

c. 1902-1903: British army (numbers not given), Abyssinian forces -5000 men under the command of Fit. Gabre and Colonel Rochfort (British officer).

d. 1903 - 1904: British forces - 7,800 men, Abyssinian army - 5000 men under Fit. Gebre and Colonel Rochfort with a British staff and medical officers attached to the Ethiopian forces (source: "Page in the History of the Ogaden by Aleme Eshete in Rubenson (ed), 1984; pp 301 $-314)$.

5. Menelik's letter to the Russian, Count Leontiev who participated in the conquest exemplifies how mercenary service was compensated during the conquest. " . . . by this letter I inform you that it is my wish to appoint you forever over the land . . . which you open. So as to pay for your losses we will give you as much as five years gratis; but after that, if in the land you have opened be found any gold, silver, ivory, coffee - as my country and my government officers, as the tribute they pay - so shall you pay your tribute. This land on the limit that I give you will be on the south side of Ethiopia". PRO: F:O. 4031255 Inclosure 88. Menelik to Count Leontiev (cited in Greenfield and Mohammed Hassan, 1980:9).

6. The language policies of the successive Ethiopian regimes have hindered the majority of the population from the acquisition of modern knowledge about health, agriculture etc. and 
have without doubt, contributed to the social and economic underdevelopment of the society. The token linguistic freedom given by the present regime has not changed the situation. In fact the policy of Amharization and the replacement of the indigenous languages by Amharic is being intensified.

7. Oromia (also spelt Oromiya) in Oromiffa (the language of the Oromo people) means the land of the Oromo. It seems to be a synthetic word from Oromo and biya (land, earth country). The name is nor communly used. So was the word Oromo until very recently. Hovever, in all the literature (political, linguistic etc.) produced by Oromo organizations such as the OLF, the Union of Oromo Students in Europe (TBOA), the Union of Oromo in North America (UONA), etc., Oromo land is refered to as Oromia. Some writers Baxter, 1983; Greenfield, 1980 etc. have adopted Oromia as the name of the territory which belongs to the Oromo although sometimes enclosed in quotation marks.

8. Most writers on Ethiopia estimate that Oromos are around 50 percent of the population. Melbaa (1980:1) gives a higher figure of 55 percent. By all estimates there are around 20 million Oromos in Ethiopia alone. The land area inhabited by the Oromos is said to be about half of the land area or, according to Melbaa (p.25) 600.000 square kilometres.

9. A French scientific mission which visited Ethiopia at the beginning of this century reported in Paris in 1906 that Roba an Arsi Abba Dula, in anticipation of Oromo independence in the future, told them: 'The hour has not come perhaps our children will see the departure of the oppressor'. Referring to this and other historical factors, Richard Greenfield and Mohammed Hassan have written that "Ever since, all over the Oromo country there have been serious traditional 'indicators' watched anxiously since they are said to herald the return of the Kao (full rights and time of happiness). Indeed there are many songs and poems about the return of the Kao" (1980: 8-9).

10. The Oromo Kingdom of Jimma was annexed as late as 1933. Until that time Abba Jifar, the King of Jimma, was its ruler although he paid tribute to the Abyssinian Emperor. On his death his kingdom was totally incorporated into Ethiopia. The land was confiscated and distributed by Haile Selassie to his generals, the Abyssinian nobility and Amhara naftanya settlers. Major Henry Darley, who lived in Kaffa at Maji during the first two decades of this century, wrote of Abba Jifar and his Kingdom that: "This town and district, at the time of which I am writing was one of the richest and most fertile, and best governed in Africa (emphasis ours). In this I do not except the white governed districts all over that continent. I have never seen people more contented. The palace was cleaner, and better ordered in every way, than the palace and court at Addis Ababa. There Abu(sic) Jifar reigns like a patriarch of old, and when he dies, his name ought long to be held in revered memory by his people. Not only has he saved them from being devoured by the Abyssinians, but by his assistance to trade, the liberality of his views, and his open-handed policy, he has brought them into the position of being the wealthiest and I fully believe, the happiest . . . state in Africa. At his death, however, I fear for the future of this people. The mouth of every Abyssinian waters when he travels through their territory, and I am sure they will make a determined effort to seize it . . . If they do so, the country will quickly revert to the same state as the rest of Abyssinia, for the wealth of this . . country is dkrived from the energy of its people, and the conciliatory rule and the liberal policy of its ruler, which encourages instead of cramping, trade and industry" (1926: 128-129).

11. Interview by the author (1983) with Ahmad Buna who was a member of the MachaTulama Association imprisoned for several years by Haile Selassie.

\section{Chapter 3}

1. These were the World-Wide Federation of Ethiopian Students (WWFES) and the World Union of Ethiopian Students (WUES). The former was organizationally connected to the EPRP and the latter to MEISON.

2. See the various issues of Democracia (1976-77) for EPRP views on this subject. 
3. This is best explained by the traditional mugit (litigation) between neighbours, often relatives, that could go on for years and could impoverish both parties since compromise was almost impossible. Such litigation also continued for a long time because the judges often take bribes from both sides and keep on postponing the verdict.

4. This was the case in Wollega where MEISON was in control up to 1977 when it split with the Dergue.

5. MEISON has been inactive since 1977. There are recent reports (see Jane's Defense Weekly, Vol. 7-16-1987) that indicate EPRP's armed activity in Gonder and Gojjam Regions.

6. It was for such purpose that the Ethiopian Review (Vol. 1 no. 1, 1977) wrote, "It is an open secret that using the nationality question as a weapon reactionaries and narrow nationalists have organized themselves as national liberation fronts . . ."

7. During the Ogaden war of 1977-78 the government controlled mass media reminsced nostalgically the exploits of the Abyssinian warriors during the conquest of the south and the previous naftanya landlords who were disarmed and driven to the major urban areas by their previous tenants were rearmed and sent back, particularly to the Oromo areas of Hararghe (Halliday and Molyneux, 1981:134) and they were called by the officialsand the mass media as hager waddad abbat arbanyoch or elderly patriots and their role in the defence of Ethiopian territorial integrity became the major theme of jingoistic Amharic songs and other programmes on the national radio and televison networks. Implicit in this was that the subject peoples of these areas are unpatriotic and hence to be suspected even though they constitute the bulk of the militia force that is used as connon-fodder in every war front.

8. Cohen and Isaksson (1987:xix) wrote that "Arsi's farmers appear to live no better and to be no better dressed or housed than they were 10 to 15 years ago".

9. See Rahmato D., Agrarian Reform in Ethiopia, 1984.

10. The meagre state revenue are drained by buildings used for political purposes, statues and propaganda. The anniversaries and public rallies cost millions of dollars every year. In 1984 the Dergue spent hundreds of millions of dollars celebrating its tenth anniversary while people in the countryside died in their thousands every day because of hunger.

11. The literacy campaign was not much more than teaching the non-Amhara peoples the Amharic (Geez) alphabet using their languages as the medium of instruction. As soon as people have learnt the alphabet those who want to be literate must switch to Amharic because, 1. There is no literature in their own languages and very little is prepared by the literacy campaign programme to solve this problem.

2. Since the Amharic alphabet is not suitable for transcribing the Kushitic languages of the majority of the population (see, Gragg, 1982: xxiii), whatever material is prepared in these languages during the campaign is difficult to read. According to Christine McNab ("Language Planning for Education in Ethiopia: Policy Development and Implementation Processes", University of Stockholm, 1987) even the literacy class instructors find it difficult to read these materials although they are themselves speakers of the nationality languages.

3. What is more the use of the nationality languages is limited to literacy classes. Someone who wants to learn more has to learn Amharic.

\section{Chapter 4}

1. The critical investigation of developments in the past helps the social scientist to understand to present. Documents and records on past events can be used, inferentially, to locate episodes which initiated problems which the social scientist wants to explore. Many of the historical documents used in this study were obtained from the Royal Library of Stockholm, the Library of the Scandinavian Institute of African Studies and the different university libraries in Sweden. Several books were also obtained through the international inter-library loan system.

2. There is a general suspicion of the motives of researchers (social scientists) among some host countries and even international voluntary organizations. Hence it is not often easy to 
obtain permits to conduct research among refugee populations. There are even some cases where issued permits are withdrawn in thk middle of field surveys (see Sidney R. Waldron, Northeast African Studies, 4.3 (1982-83, p. 17).

3. At the time of the survey there were about 160,000 urban and 300,000 rural refugees in Eastern Sudan. All of them originated from Ethiopia. About 100,000 of those were accommodated in organized rural and semi-urban settlements. The rest, about 360,000 , were living in scattered spontaneous rural and urban environments. The samples are drawn from both types of settlements. However, organized settlements which were inhabited entirely by Eritrean refugees were not included in the sample. This was mainly because a similar study was undertaken at the same time by a colleague (see Kibreab, 1985) and duplication was found to be unnecessary. Instead information gathered by my colleague is used as complementary data in this study. Eritreans who lived in the selected sites for this study are included in the household samvles.

4. Different sources give different estimates reagrding the size of the refugee population in Gedaref. An ILO/UNHCR report (ILO, 1986) mentions 30,000 as the number of refugees in Gedaref and 10,000 in Tawawa which is located 7 kilometers outsides of the city. Jan Post (1983) gives 17,000 as the lower and 32,000 as the higher estimate for Gedaref and Tawawa together. According to our estimation the refugee population in Gedaref city was at most 20,000 in $1982-83$.

5. Since the interviewers employed in this survey had previously participated in similar activities among the refugee households in Gedaref it was not particularly difficult to locate most of the refugee households in this section of the city. However, since there was no map that clearly delimits Deim el Nur from the other neighbouring deims, it is not sure whether we were able to include every refugee household in the whole quarter. However, it may not make much difference to the outcome since the large majority of the households were identified and registered and a random sample has drawn from the register.

6. Lars Jonsson commented that using refugees as interviewers was one of the factors which played an important part in diminishing the reliability of the socio-economic data he collected in the Suki settlement scheme (1982). According to Jonsson the interviewers who were of the same ethnic origin as the refugees were affected by the difficult situation their compatriots were in and could have manipulated some of the responses particularly concerning income. We were aware of such a situation from the beginning and interviewers were informed of the sole academic nature of the study and were asked to tell the same to respondents and record their responses objectively.

\section{Chapter 5}

1. See Berliner Mission, "Revolution and Nation, Human Right and Refugee Relief. A Statement" (Frankfurt) 1982 p.9. See also Halliday and Molyneux 1981 p. 123.

2. It was commonly asserted that those parents who were allowed to take the bodies of their children for burial were charged Birr 150-200 by the regime.

3. Bereket Habte Selassie (1980:42) wrote the "young children of the people arrested or killed were left without care and their neighbours, who could customarily have taken them were forbidden to do so".

4. No clear instruction or guidance was provided to the hastily organized kebele guards. They acted according to personal judgement even when this involved human lives. Some, like Girma Kebede, used the situation to get morbid satisfaction. Girma Kebede, a kebele chairman, tortured and slaughtered 22 person including a woman in her eighth month of pregnancy in one of the kebeles.

5. Rene Lefort (1983:171) maintains that it was MEISON and above all Daniel Tadesse, the then Minister of Public Works and Housing, who perceived that the lumpen proletariat organized as kebele defence squads was the prize in the decisive battle for the survival of their side. 
6. Fred Halliday and Maxine Molyneux (1981:123) wrote that in February 1978 "we attended a conference in the former National Assembly building in Addis Ababa where three anonymous members of POMOA openly justified the use of terror and the carrying out of instantaneous executions without any judicial procedures".

7. It is difficult to get an accurate figure regarding the intellectuals, professionals and skilled people who left Ethiopia after the military take over. The UNHCR magazine Refugees disclosed in its issue of September, 1984 that between 1980 and 1983 nearly 10,000 refugees from Africa, mainly Ethiopians, were resettled in the U.S. Norman Zucker (1984) estimated that 20-30,000 Ethiopians have entered the U.S. since 1974. It is clear from our observations that refugees in Europe and America are amongst the most educated and skilled members of Ethiopian society. There are more Ethiopian medical doctors (refugees) in Sweden alone than in some of the 14 regions in Ethiopia.

8. It seems that the dream of every young and educated person is to leave Ethiopia. Every possibility is exploited to realize such dreams. It is common today that officials sent on government delegations abroad fail to return home. Parents still encourage their children to leave and those who have sons and daughters studying abroad advise them not to return. What is remarkable is that even high government officials who are otherwise in advantageous positions send their children abroad.

9. See Vårt Land (Oslo) April 1981. The newspaper quotes Norwegian missionaries stationed in Sidamo at the time of the incident.

10. The table below shows the rapid increase of refugees in Somalia just after the Ogaden war (in thousands).

\begin{tabular}{lll}
\hline Month & Influx & Total \\
\hline January & - & 100.0 \\
February & 14.0 & 114.0 \\
March & 12.0 & 126.0 \\
April & 44.0 & 170.0 \\
May & 25.0 & 195.0 \\
June & 35.0 & 230.0 \\
July & 40.0 & 270.0 \\
August & 40.0 & 310.0 \\
September & 21.0 & 331.0 \\
October & 21.0 & 352.0 \\
November & 39.0 & 391.0 \\
December & 84.0 & 475.0 \\
\hline
\end{tabular}

Source: Göran Melander: Refugees in Somalia, Scandinavian Institute of African Studies, 1980.

The official Somali estimate of refugees from Ethiopia at 1,5 million persons was challenged by voluntary agencies. Therefore the UNHCR in agreement with the Somali government adopted an estimated camp population of 700,000 for planning purposes. However, it is also believed that thousands of refugees are also settled spontaneously.

11. The author was in Wollo when the 'Peasant March' on Eritrea was conducted and saw lorry loads of ill- organized and ill-equipped peasants heading for the north with a few regular military men and vehicles as escorts.

12. One of the labour camp escapees interviewed by the Anti-Slavery Society reported that six people died on the way from Addis to Humera in his cohort and that three became seriously ill (ASS, 1979).

13. Between 200,000 and 250,000 people were resettled in the south and southwest between 1979 and 80. In 1984-85 about 800,000 people were resettled mainly in the south western regions (see Triulzi, 1983:123; Clay and Holcomb, 1986:8). 
14. Peter Niggli provides a graphic reconstruction of the transportation to resettlement areas based on his interviews with resettlement escapees. He writes, "First one has to imagine the masses of people penned up for two to four weeks during the time of transport to the resettlement areas: they were rounded up by the hundreds in their villages and in the towns, in the collection-camps they already numbered by the thousands. The truck and bus convoys included 30 to 100 vehicles, the helicopters and planes shuttled several times a day. There were waitingperiods of several days between the different transports. The people were detained in the courts of public buildings or in the open field - during the day they had to stay in the sun without shelter, they were cold at night" (1985).

15. According to the Ethiopian Herald of October 28,1986, about 554,000 households with about two million members were moved into new villages between October 1985 and February 1986. The time coincides with the harvesting season in Ethiopia.

16. Peasants told Cohen and Isaksson that because of the villagization they (the peasants) now know each other and could work on common problems. Cohen and Isaksson added: "When we asked for examples the only one they could give was "to help put out fires" (1987:194).

17. See Makonen Getu, Socialism, Participation, and Agricultural Development in Post Revolution Ethiopia: A Study of Constraints, 1987.

18. Cohen and Isaksson's (1987) report shows that the only functioning programme in the new villages was literacy. For the links between literacy and Amharization see Chapter 3, footnote 11 .

\section{Chapter 6.}

1. The author was working for the RRC at that time.

2. Agro-pastoralists could also be more vulnerable due to the topography of their habitat. In the highlands where most of the peasants live, it is often possible to take refugee in the hills for weeks or months from air raids and the onslaught of hostile forces. The topography of the lowlands where pastoralists and agro-pastoralists live does not provide such protective shelters. Therefore, flight becomes the only way to avoid danger.

3. The most striking example of violence against people in flight occurred in south-east Asia in 1983 and 1984. Then it was estimated that about 40 per cent of the boats carrying refugees were victims of pirate raids. In such raids tens of thousands of refugees were victimized. Thousands of women were raped (Refugees, no. 2, 1984).

4. Harassments and military attacks on refugee camps have become quite common all over the world. In Africa it occurs often in southern Africa where south African forces, had on several ocassions crossed the borders of the neighbouring countries and caused death and destruction (see Refugees, no.4, 1983).

5. Refugees, op.cit. p. 33, indicated that there were cases when refugees were kept in detention up to 6 years. Detention and confinement often involves even children and are carried out even by some European countries.

\section{Chapter 7}

1. See also the ILO-UNHCR survey (ILO, 1984b:104-128)

2. It was not always easy to determine if all of the women who replied that they were married were actually married. In some communities like Gedaref and Tawawa there was a practice whereby a woman who usually earns her livelihood as a prostitute enters an arrangement with a man who acts as her protector against other men and poses as her husband before the authorities of the country of asylum. In reality there is no marriage contract between these people. He may sleep freely in the woman's house every night. He perhaps gets his food there but he does not contribute to the economy of the household although he may have income. Women who live in such relations have responded to our enquiry on their marital status as "married". When we take this into consideration the number of female household heads is certainly higher than what we recorded. 
3. About 20 per cent of the respondents were Muslims and polygamous mamages were recorded amongst them.

4. From an ILO-UNHCR survey (ILO, 1984b:59) covering 12 sample sites, the proportion of female household heads was reported to be between zero and 51 per cent. Jan Post (1983b:4) reported that 25 per cent of the refugee households in Port Sudan had female heads of household.

5. The ILO-UNHCR survey (op. cit., p.60) indicated that 21 per cent of the female household heads were married, 71 per cent widowed, divorced or separated mainly as the consequence of war and uprooting. Only 8 per cent of the female heads of household were single. 


\section{References}

Aall, C. 1967. "Refugee Problems in Southern Africa", in Refugee Problems in Africa, Hamrell, S. (ed.) Uppsala: Scandinavian Institute of African Studies.

Abas Haji. 1982. "The History of Arsi: 1880-1935", B.A. Thesis, Department of History, Addis Ababa University, mimeo.

Addis Hiwet. 1975. "Ethiopia: From Autocracy to Revolution," Review of African Political Economy, Occasional Publications, No. 1, London.

- 1984. "Analysing the Ethiopian Revolution", Review of African Political Economy, No. 30, London.

Aga Khan, S. 1976. "Lectures by Sadruddin Aga Khan, United Nations High Commissioner for Refugees on Legal Problems relating to Refugees and Displaced Persons given at the Hague Academy of International Law", 4-6 August. UNHCR, mimeo.

- 1981. "Question of the Violation of Human Rights and Fundamental Freedoms in any Part of the World, with Particular Reference to Colonial and Dependent Countries and Territories: Study on Human Rights and Massive Exoduses", United Nations Commission on Human Rights , rnimeo.

-. 1983. "The dull edges of our dogmas", Refugees, No. 17, UNHCR, Geneva.

Aiboni, S. 1978. Protection of Refugees in Africa, Uppsala: Svenska Institutet for Internationell Ratt.

Amin, S. 1974. "Introduction", in Amin, S. (ed.), Modern Migration in Western Africa, Oxford University Press.

Amnesty International. 1983. Amnesty International Report 1983, London. pp. 31-34.

Anti-Slavery Society (ASS). 1979. "Forced Labour in Ethiopia - Slavery in the Sesame Fields", Report to the UN Working Group of Experts on Slavery, mimeo.

Badume, Idris, and Tesfay Berhane. 1981. "The Refugee Situation in the Horn of Africa: Field Investigation", n.p., mimeo., March.

Bakke, Johnny. 1986. Christian Ministry: Patternsand Functions within the Ethiopian Evangelical Church Mekane Yesus, Department of Theology, University of Uppsala.

Baldridge, J.V., 1975: Sociology: A Critical Approach to Power, Conflict and Change, New York: John Wiley and Sons, Inc.

Baskauskas, L. 1981. "The Lithuanian Refugee Experience and Grief", International Migration Review, Vol. 15 No. 1-2, New York: Center For Migration Studies, pp. 276-291.

Baxter, Paul T.W. 1978. "Ethiopia's Unacknowledged Problem: The Oromo", African Affairs: The Journal of the Royal African Society, Vol. 77, No. 208, pp. 283-296.

- 1983. "The Problem of the Oromo or the Problem for the Oromo?" in Nationalism and Self-Determination in the Horn of Africa, Lewis, I.M. (ed.), London: Ithaca Press.

Bekele, Mesfin. 1980. "Prison Conditions in Ethiopia", mimeo.

Bennet, F.J., and Assael, M.I. 1970. "The Mental Health of Immigrants and Refugees from Rwanda at Kasangat, Uganda", Psychopathologie Africaine, Vol. 4, No. 3, Dakar.

Bernard, W.S. 1973. "Indices of Integration in the American Community", International Migration: Quarterly Review of the Intergovernmental Committee for European Migration and the Research Group for European Migration Problems, Vol. 11, No. 3, The Hague.

Betts, T.F. 1980. "Spontaneous Settlement of Rural Refugees in Africa", London: Euro Action-ACCORD, April.

. "Rural Refugees in Africa", International Migration Review, Vol. 15, Nos. 1-2, pp. 213-218.

Billard, A. 1986. "Eastern Sudan: Huge Efforts Paying off', Refugees, No.27, UNHCR, Geneva, pp. 19-22 and 27-29.

Bjerén, Gunilla. 1985. Migration to Shashemene: Ethnicity, Gender and Occupation in Urban Ethiopia, Uppsala: Scandinavian Institute of African Studies.

Boesch, Ernst. 1982. "From Expulsion to Hospitality: A Psychologist's Look at the Refugee 
Problem", in Refugees and Development, Boesch, E. and Goldschmidt, A. (eds.), BadenBaden: Nomos Verlagsgesselschaft.

Bondestam, L. 1974. Den Domda Dalen: Om kapitalism och människor i nordostra Etiopien. Lund: Berlingska Tryckeriet.

- 1975: Feodalismen skall krossas: Om inledningen till revolutionen $\boldsymbol{i}$ Etiopien, Lund: Berlingska tryckeriet.

Borrie, W.D. 1959. Cultural Integration of Immigrants, Paris: UNESCO.

Braukamper, Ulrich. 1982-83. "Ethnic Identity and Social Change Among Oromo Refugees in the Horn of Africa", Northeast African Studies, Vol. 4, No.3, pp. 1-15.

Breton, R. 1964. "Institutional Completeness of Ethnic Communities and the Personal Relations of Immigrants", The American Journal of Sociology, Vol. 70, PP: 193-205.

Broom, L. and Selznick, P. 1968. Sociology, New York: Harper International.

Bulcha, Mekuria. 1973. "Eder: Its Roles in Development and Social Change in Ethiopian Urban Centres", Unpublished B.A. Thesis, School of Social Work, Addis Ababa University.

- 1979. "The Social Structure of Feudal Ethiopia: Background to the 1974 Popular Uprising", International Graduate School, Stockholm University, Unpublished manuscript.

- 1983. "Some Notes on the Conditions of Oromo, Berta and other Refugees in the Kurmuk District of Blue Nile Province, Republic of Sudan", Unpublished manuscript, Khartoum.

- 1984. "The Social and Economic Foundations of the Oromo States of the 19th Century: Social Differentiation and State Formation Among the Macha Oromo circa 1700-1900", Department of Sociology, University of Uppsala.

-. 1987a: "Historical, Social and Political Causes of Mass Flight From Ethiopia", in Nobel, Peter (ed.) Refugees and Development in Africa, Uppsala: Scandinavian Institute of African studies.

- 1987b: "Sociological and Economic Factors in Refugee Integration: The Case of Ethiopian Exiles in the Sudan", in Nobel, Peter (ed.), op. cit.

Cerulli, Erico. 1917. Folk-Literature of the Galla of Southern Abyssinia, Harvard African Studies III, Cambridge, Massachussets.

Chambers, Robert. 1979. "Rural Refugees in Africa: What the Eye Does Not See", Disasters, Vol.3, No.4, pp. 381-392.

- 1982. "Rural Refugees in Africa: Past Experience, Future Pointers", Paper Presented at the Khartoum Refugee Seminar, 11-14 September.

- 1984. "Hidden Losers? The Impact of Rural Refugees and Refugee Programmes on the Poorer of their Hosts", Institute of Development Studies, University of Sussex, mimeo.

Chege, M. 1979. "The Revolution Betrayed: Ethiopia 1974-79", Journal of Modern African Studies, Vol. i7, No.3, pp. 370-379.

Christensen, Hanne. 1982. Survival Strategies For and By Camp Refugees: Report on a Six-Week Exploratory Sociological Field Study into the Food Situation in Refugees in Camps in Somalia, United Nations Research Institute for Social Development (UNRISD) Report No. 82.3, Geneva: United Nations.

Clapham, C. 1969. Haile Selassie's Government, London: Longmans.

Clay, Jason and Holcomb, Bonnie. 1985. Politics and the Ethiopian Famine 1984-1985, Cultural Survival Incorporation Occasional Papers 20, Cambridge, Massachussets.

Cohen, J. and Isaksson, N. 1987. "Villagization in the Arsi Region of Ethiopia", Rural Development Studies No. 19, Uppsala: Swedish University of Agricultural Sciences.

Cohen, R. and Middleton, J. 1970. "Introduction" in From Tribe to Nation in Africa: Studies in Incorporation Process, Cohen, R. and Middleton, J. (eds.), Scranton: Chandler Publishing Company.

Cohon, J. Donald. 1981. "Psychological Adaptation and Dysfunction among Refugees", International Migration Review, Vol. 15, Nos. 1-2 pp. 255-275.

Coser, L. 1956. The Functions of Social Conflict, London: Free Press of Glencoe. 
Dahrendorf, R. 1958. "Out of Utopia: Toward a Reorientation of Sociological Analysis", American Journal of Sociology, Vol. 64.

Darkwah, R.H.K. 1978. Shewa, Menilek and the Ethiopian Empire: 1813-1889, London: Heinemann.

Darley, Henry. 1926. Slaves and Ivory: A Record of Adventure and Exploration in the Unknown Sudan, and Among the Abyssinian Slave-Raiders, London.

Davidson, Basil. 1980. Black Mother Africa and the Atlantic Slave Trade, Penguin Books.

-. Cliffe, L. and Habte Selassie, (eds.). 1980. The War in Eritrea, Spokesman and ROAPE.

Day-Thompson, M. 1984. "Refugees: A Case for Hard-Nosed Help". Paper Presented at the symposium, "Assistance to Refugees: Alternative View Points" Oxford, March. Mimeo.

Dibaba, Terfa. 1982. "The Refugee Camps in the Blue Nile Province of Sudan: Travel Report" Unpublished Manuscript.

Documentation for Khartoum Conference. 1980. Vols. I, II, and III Kartoum. National Commitee for Aid to Refugees.

Domenach, Jean-Marie. 1981. "Violence and Philosophy", in Violence and its Causes, Paris UNESCO.

Donham, D. 1986. "Old Abyssinia and the New Ethiopian Empire: Themes in Social History", in The Southern Marches of Imperial Ethiopia: Essays in History and Social Anthropology, Donham, D. and James, W. (eds.), Cambridge: Cambridge University Press.

Durkeim, Emile. 1951. Suicide, New York: The Free Press.

Economic and Social Research Council, National Council For Research (ESCR). 1982. "Socio-Economic Survey of Spontaneously-Settled Refugees in Port Sudan", Research Report No. 13, Khartoum. February.

Elamin, Hassan Bella. 1982. "Our Refugee Guests in the Sudan and ther Burden of IllHealth", Paper Presented at Khartoum Refugee Seminar, 11-14 September, mimeo.

El-Beshir, Abdel Rahman. 1982. "Some Notes from Problems of Settlement of Migrants and Refugees in Sudanese Society", Paper Presented at Khartoum Refugee Seminar, 11-14 September, mimeo.

El-Bushra, Judy. 1982. "Education and Training Needs for Refugees: Some Planning Considerations", Paper Presented at Khartoum Refugee Seminar, 11-14 September, mimeo.

El-Dawi, Taj El-Aniba. 1979. "Eritrean and Ethiopian Refugees in Khartoum", UNHCR, mimeo.

Elgaali, Bukhari. 1983. "Refugees and Development: The Case of the Sudan" Refugees and Development, Boesch, E. and Goldschmidt A. (eds.), Baden-Baden: Nomos Verlagsgesellschaft.

Eitinger, L. 1973. "Mental Disease among Refugees in Norway after World War 11", in Uprooting and After, Zwingmann, C. and Pfister-Ammende, M. (eds.), Berlin/Heidelberg : Springer-Verlag.

-. and Grunfeld, B. 1966. "Psychoses among Refugees in Norway", Acta Psychiatrica Scandinavica, No. 42, pp. 315-328.

Eisenstadt, S.N. 1954. The Absorption of Immigrants, London: Routledge and Kegan Paul Ltd.

Elias, Tseggai. 1982. "The Impact of Eritrean Refugees on the Eastern Region of the Sudan", Unpublished Masters Degree Thesis, Institute of Social Studies, The Hague.

Firebrace, J. and Holland, S. 1984. Never Kneel Down: Drought Development and Liberation in Eritrea, Nottingham: Russell Press Ltd.

Freedman, R. 1973. "Nutrition Problems and Adaptation of Migrants in New Cultural Environment", International Migration, Vol. XI., No. 1,2,3 pp. 15-31.

Galtung, Johan. 1968. "A Structural Theory of Integration", Journal of Peace Research. Vol. 4, pp. $375-395$. 
Garcia, J.A. 1981. "Political Integration of Mexican Immigrants: Exploration into the Naturalization Process", International Migration Review, Vol. 15, Nos. 3-4, pp. 608-625.

Gasarasi, C.P. 1976. "The Life of a Refugee Settlement: the Case of Mugenzi in Ngara District, Tanzania", UNHCR and University of Dar es Salaam, mimeo.

Gellner, Ernest. 1983, Nations and Nationalism, Oxford: Basil Blackwell.

Germani, G. 1981. The Sociology of Marginality, New, Brunswick: Transaction Books.

Getu, M. 1978. Socialism, Participation, and Agricultural Development in Post-Revolutionary Ethiopia: A Study of Constraints, Stockholm: Almqvist \& Wiksell International.

Gilkes, Patrick. 1975. The Dying Lion: Feudalism and Modernization in Ethiopia, London: Julian Friedman.

Goldenberg, Milton. 1941. "A Qualification of Marginal Theory", American Sociological Review Vol. 6, No. 1, pp. 52-58.

Goldlust, J. and Richmond, A.H. 1974. "A Multivariate Model of Immigrant Adaptation", International Migration Review, Vol. 8, No. 2, pp. 193-225.

Gould, W.T.S. 1974. "Refugees in Tropical Africa", International Migration Review, Vol. 13, No. 3, pp. 413-430.

Goundrey, Gordon K. 1984. "The Problem of Asylum For Refugees: A Suggested Approach", DERAP Working Papers A 312. Chr-Michelsen Institute, Bergen, mimeo.

Gragg, G. 1982. Oromo Dictionary, East Lansing: African Studies Center, Michigan State University.

Green, Vera. 1974. Migrants in Aruba: Interethnic Integration, Assen: Carnation Books.

Greenfield, Richard. 1965. Ethiopia: A New Political History, London: Pall Mall Press.

- 1979. "An Historical Introduction to Refugee Problems in the Horn", Horn of Africa. Vol. 2, No. 4, pp. 14-26.

- 1980. "The Current Refugee Situation in Northeast Africa: A Problem in Afro-Arab Relations?", Paper Presented at Symposium on Afro-Arab Relations in the Eighties, Cairo, 21-24 January.

-. 1984. The OAU and Africa's Refugees, Assistance to Refugees: Alternative Viewpoints Symposium, Oxford University.

-. and Mohammed Hassan. 1980. "Interpretation of Oromo Nationality", Horn of Africa, Vol. 3, No. 3, pp. 3-14.

Griffin, K. and Hay, R. 1985. "Problems of Agricultural Development in Socialist Ethiopia: An Overview and Suggested Strategy", The Journal of Peasant Studies, Vol. 13, No.1, pp. 37-66.

Habte Selassie, Bereket. 1980. Conflict and Intervention in the Horn of Africa, New York: Monthly Review Press.

Halliday, F. and Mollyneux, M. 1981. The Ethiopian Revolution, London: Verso.

Hansen, Art. 1981. "Once the Running Stops: Assimilation of Angolan Refugees in Zambian Border Villages", Disasters, Vol. 3, No. 4, pp. 369-374.

-.1982. "Self-Settled Rural Refugees in Africa: The Case of Angolans in Zambian Villages" in Hansen, Art and Oliver-Smith, Anthony (eds.).

- and Oliver-Smith, Anthony (eds.). 1982. Involuntary Migration and Resettlement: The Problems and Responses of Dislocated People, Boulder/Colorado: Westview Press.

Harrell-Bond, B.E. 1986. Imposing Aid: Emergency Assistance To Refugees, Oxford: Oxford University Press.

Hasselblatt, Gunnar. 1980, Schrie im Oromoland, Stuttgart: Radius-Verlag.

Healy, S. 1983. "The Changing Idiom of Self-Determination in the Horn of Africa", in I.M.Lewis (ed.) op.cit.

Himmelstrand, Ulf. 1971. "Rank Equilibration, Tribalism and Nationalism in Nigeria", in Nigeria: Modernization and the Politics of Communalism, Melson, R and Wolpe, H. (eds.), Michigan State University Press.

--.1977. "Internationalization and Application: Extending the Reach of Survey Research, in 
Cross National Comparative Survey Research, Szalai, A. and Petrella, R. (eds.), Oxford and New York: Pergamon Press.

Holborn, Louise, W. 1975. Refugees: A Problem of Our Time, Metuchen New Jersey: Scarecrow Press.

Holcomb, Bonnie. 1984. "Crisis in the Colonies: Ethiopia and Portuguese Dependent Colonialism-Compared", Paper Presented at the Oromo Conference held in Berlin, July 29-30. Unpublished manuscript.

Homans, G.C. 1965. The Human Group, London: Routledge and Kegan Paul Ltd.

Hultin, J. 1978. The Long Journey: Essays on History, Discent and Land Among the Macha Oromo, Uppsala: Uppsala University.

Hultåker, O. and Trost, J. 1976. "The Family and the Shelters", in Disaster Studies, No.1, University of Uppsala.

Ilfield, F. and Metzner, R. 1970. "Alternatives to Violence: Strategies for Coping with Social Conflict", in Violence and the Struggle for Existence, Daniels, D., Gilula, M. and Ochberg, F. (eds.), Boston: Little, Brown and Company.

International Institute of Humanitarian Law. 1981. "Problems Arising from the Large Numbers of Asylum-Seekers: A Study of Protection Aspects." San Remo, Italy, June.

International Labour Office. 1984a. Labour Markets in the Sudan, Geneva:ILO.

- 1984b. Towards Self-Reliance:A Programme of Action for Refugees in Eastern and Central Sudan, Geneva: ILO.

Jésman, C. 1958. The Russians in Ethiopia: An Essay in Futility, London: Chatto and Windus.

Jonsson, Lars. 1982. "Suki Socio-Economic Survey", UNHCR Report, Unpublished, Gedaref, March.

Kakwenzaire, P.K. 1985. "Sayyid Muhammed Abdille Hassan, Lij Yasu and the World War I Politics: 1914-1916”, Transafrican Journal of History, Vol. 14. pp. 3645.

Karadawi, Ahmed. 1982. "Definition of a Refugee: Changing Concepts", Paper Submitted to Khartoum Refugee Seminar, 11-14 September.

- 1983. "Constraints on Assistance to Refugees: Some Observations from the Sudan", World Development. Vol. 11, No. 6, pp. 537-547.

Kebede, Teshome. 1984. "Some Aspects of Feudalism in Ethiopia", in Proceedings of the Seventh International Conference of Ethiopian Studies", Rubenson, Sven (ed.), Addis Ababa: Institute of Ethiopian Studies.

Keller, E. 1981. "Ethiopia: Revolution, Class and the National Question", African Affairs, Vol. 80, No. 321, pp. 519-549.

-. 1984. "The Ethiopian Revolution: How Socialist Is It?", Journal of African Studies, Vol. 11, No. 2. pp. 52-65.

Kemper, Theodore E. 1978. "Toward a Sociology of Emotions: Some Problems and Some Solutions", The American Sociologist, Vol. 13, pp. 30-41.

Khera, S., and Mariella, P.S. 1983. "The Fort McDowell Yavapai: A Case of Long-Term Resistance to Relocation", in Involuntary Migration and Resettlement, Hansen A., and Oliver-Smith, A. (eds.), Boulder/Colorado: Westview Press.

Kibreab, Gaim. 1985. "A Study of Organized Settlements for Eritrean Refugees in Eastern Sudan: 1967-1983". Unpublished Ph.D. Thesis, Department of Economic History, Uppsala University, Uppsala.

-. 1983. Reflections on the African Refugee Problem: A Critical Analysis of Some Basic Assumptions, Uppsala: Scandinavian Institute of African Studies.

Kiss, Judit. 1977. Will Sudan be an Agricultural Power? Studies on Developing Countries Series, No. 94. Budapest.

Knutsson, Karl-Eric. 1967. Authority and Change: A Study of the Kallu Institution Among the Macha Galla of Ethiopia, Goteborg: Etnografiska Museet.

- 1969. "Dichotomization and Integration: Aspects of Inter-Ethnic Relations in Southern Ethiopia", in Ethnic Groups and Boundaries: The Social Organization of Culture Difference, Barth, F. (ed.) Bergen and Oslo: Universitets Forlaget. 
Kritz, M., Keely, C. and Tomasi,M. 1983. Global Trends in Migration: Theory and Research on International Population Movements,. New York: Center of Migration Studies.

Kunz, Egon F. 1973. "The Refugee in Flight: Kinetic Models and Forms of Displacement", International Migration Review, Vol. 7, No. 2, pp. 125-146.

- 1981. "Exile and Resettlement: Refugee Theory, Internation Migration Review, Vol. 15, Nos. 1-2, pp. 42-51.

Kuper, Leo. 1969. "Plural Societies: Perspectives and Problems", in Pluralism in Africa, Kuper, L. and Smith, M. (eds.), Berkeley and Los Angeles: University of California Press.

-. 1980. "The Theory of Plural Society, Race and Conquest", in Sociological Theories: Race and Colonialism, Paris: UNESCO.

Kuru, A. 1986. Soil Erosion and Strategic State Policy: The Case of Ethopia, Helsinki: University of Helsinki.

Lamb, David. 1983. "Problem on its Own Doorstep", Refugees, No.24, p.7.

Lee, E. 1969. "A Theory of Migration", in Migration, Jackson J.A. (ed.) Cambridge University Press.

Lees, F.A. and Brooks, H.C. 1977. The Economic and Political Development of the Sudan. London: MacMillan Press Ltd.

Lefort, Rene. 1983. Ethiopia: An Heretical Revolution?, London: Zed Press.

Legesse, Asmerom. 1973. Gada: Three Approaches to the Study of African Society, London: MacMillan.

Legum, Colin and Lee, Bill. 1979. The Horn of Africa in Continuing Crisis, New York and London: Africana Publishing Company.

Levine, D. 1965. Wax and Gold: Tradition and Innovation in Ethiopian Culture, Chicago and London.

Lewis, Herbert, S. 1965. A Galla Monarchy: Jimma Abba Jiffar, Ethiopia 1830-1932, Madison: University of Wisconsin Press.

Lewis, I.M. 1983. "Introduction", in Nationalism and Self-Determination in the Horn of Africa, Lewis, I.M. (ed.), London: Ithaca Press.

Lipsky, E.A. 1962. Ethiopia: Its People, Its Society, Its Culture, New Haven: HRAF Press.

Little, Kenneth. 1965. West African Urbanization, Cambridge: Cambridge University Press.

Lopez, G. 1984. "A Scheme for the Analysis of Government as Terrorist", in Stohl, M. and Lopez, G. (eds.)

Luckman, R. and Bekele, D. 1984. "Foreign Powers and Militarism in the Horn of Africa, Review of African Economy, No. 30, pp. 9-22.

Lukes, S. 1973. Emile Durkeim: His Life and Work, Middlesex: Penguin Books.

Marcus, Harold G. 1975. The Life and Times of Menelik 11, Oxford: Clarendon Press.

Markakis, J. 1984. "Material and Social Aspects of National Conflict in the Horn of Africa", in Rubenson, S. (ed.) (see below).

Mazrui, Ali. 1969. "Pluralism and Integration", in Pluralism in Africa, Kuper, L and Smith, M. (eds.), Berkeley and Los Angeles: University of California Press.

McClellan, C.W. 1980. "Land, Labour and Coffee: The South's Role in Ethiopian SelfReliance, 1889-1935", African Economic History, No. 9, pp. 69-83.

McGowan, P, and Johnson, T.H. 1986. "Sixty Coups in Thirty Years: Further Evidence Regarding African Coups d'état', The Journal of Modern African Studies, Vol. 24, No. 3 , pp. 539-546.

McHale, John and Magda. 1978. Basic Human Needs, New Brunswick/New Jersey: Transaction Books.

Melander, Göran. 1978. "Refugees in Orbit", in African Refugees and Law, Melander, G. and Nobel, P. (eds.), Uppsala: The Scandinavian Institute of African Studies.

-. 1980. Refugees in Somalia, Uppsala: Scandinavian Institute of African Studies.

Melbah, Gadaa. 1980. Oromia, Finfine. 
Mertens, P. 1981. "Institutional Violence, Democratic Violence and Repression", in Violence and its Causes, UNESCO Insight Series no. 4., Paris.

Merton, R. 1968. Social Theory and Social Structure, New York: The Free Press.

Metcalfe, George. 1970. "Effects of Refugees on the National State", in Refugees South of Sahara, Brooks, H.C. and El-Ayouty, Y (eds.), Westport/Connecticut: Negro University Press.

Mohamed Hassan. 1983. "The Oromo of Ethiopia, 1500-1850: with Special Reference to the Gibe Region", Unpublished Ph.D. Thesis, School of Oriental and African Studies, University of London.

- 1984. "The Oromo Resistance from the Scramble for African to the Present", Paper Presented at the Conference on the Horn of Africa, Washington D.C., August.

New African, No. 217,1985, "Ethiopia's Oromos Take on the Dergue", London: IC Publications Ltd.

Niggli, Peter. 1985. Ethiopia: Deportation and Enforced-Labour Camps. Doubtful Methods in Struggle Against Famine, Berlin: Berliner Missionswerk.

Nobel, Peter. 1982. Refugee Law in the Sudan, Uppsala: Scandinavian Institute of African Studies.

- 1987. (ed). Refugees and Development in Africa, Uppsala: Scandinavian Institute of African Studies.

Norberg, V.H. 1980. "Swedes as a Pawn in Haile Selassie's Foreign Policy: 1924-1952", in Modern Ethiopia, Tubiana, J. (ed.), Rotterdam: A.A. Balkema.

Oliver-Smith, Anthony. 1982. "Here There is Life: The Social and Cultural Dynamics of Successful Resistance to Resettlement in Postdisaster Peru", in Hansen, A.and OliverSmith, A. (eds.), op.cit.

-. and Hansen, Art. 1982. "Introduction. Involuntary Migration and Resettlement: Causes and Contexts", in Hansen, Art and Oliver-Smith Anthony (eds.), op.cit

Oromo Relief Association (ORA). 1980. "Oromo Relief Association. Special Issue No. 1",Khartoum, mimeo, March.

-. 1982. "Bulletin 1982", Khartoum, mimeo., January.

-. 1986. "Report: First half of 1986", Khartoum, mimeo.

Oste, Sven. 1984. "Svalten loser problemet med de upproriska", Dagens Nyheter, Stockholm, November 25.

Ottaway, Marina and David. 1978. Ethiopia: Empire in Revolution, New York: Africana Publishing Co.

Palacio, J.O. 1982. "Posthurricane Resettlement in Belize", in Involuntary Migration and Resettlement, Hansen, A. and Oliver-Smith, A. (eds.), op. cit.

Palmer, Ingrid. 1982. "Women Refugees in Urban and Rural Settlements", Paper Presented at Khartoum Refugee Seminar, September 11-14. mimeo.

Pankhurst, Richard. 1966. State and Land in Ethiopian History, Addis Ababa: Institute of Ethiopian Studies.

Park, R.E. 1928. "Human Migration and the Marginal Man", American Journal of Sociology, Vol. 33, No. 6, pp. 881. 893.

Pausewang, Siegfried. 1973. Methods and Concepts of Social Research in a Rural Developing Society: A Critical Appraisal Based on Experience in Ethiopia. IFO Institut für Wirtschaftsforschung, Miinchen: Weltforum Verlag.

- 1978. "Peasants and Local Society in Ethiopia: Land Tenure, Social Structure and Land Reform". DERAP Working Papers No. 105, Chr. Michelsen Institute, Bergen.

Perham, Margery. 1969. The Government of Ethiopia, London: Faber and Faber Limited.

Perlman, Janice. 1976. The Myth of Marginality, Berkeley/ Los Angeles: University of California Press.

Petras. J.F. and Morley, M.H. 1984. "The Ethiopian Military State and Soviet-U.S. Involvement in the Horn of Africa", Review of African Economy, No. 30, pp. 21-32. 
Pfister-Ammende, M. 1973: "The Problem of Uprooting" in Uprooting and After, Zwingmann, C, and Pfister-Ammende, M. (eds.), Berlin/Heidelberg: Springer-Verlag.

Pitterman, S. 1984. "Determinants of Policy in a Functional International Agency: A Comparative Study of United Nations High Commissioner for Refugees (UNHCR) Assistance in Africa, 1963-1981”, Unpublised PH.D. Dissertation, Evanston, Illinois.

Polhemus, James. 1985. "The Refugee Factor in Botswana, Immigrants and Minorities, Vol. 4, No.1.

Porter, Jack Nusan (ed.). 1982. Genocide and Human Rights. Lanham/New York: University Press of America.

Post, J. 1983a. "Consideration on the Settlement of Urban Refugees in Eastern Sudan", Work Document 1, Department of Town and Village Planning, Ministry of Construction and Public Work, Republic of Sudan and Department of Urban and Regional Planning, Free University, Amsterdam. Unpublished. March.

- 1983b. "Evaluation of the Spontaneous Spatial Integration of Refugees in Port Sudan", Work Document", (as above), October.

Price, Charles. 1969. "The Study of Assimilation", in Migration, Jackson, J.A (ed.), op.cit.

Prins, S.A. 1955. "The Individual in Flight", in Flight and Resettlement, Murphy, H (ed.), Paris: UNESCO.

Provisional Military Administrative Council. 1977. The Ethiopian Revolution: Third Anniversary, Addis Ababa.

Provisional Office for Mass Organizational Affairs. 1977. Basic Documents of the Ethiopian Revolution, Addis Ababa.

Radecki, H. 1979. Ethnic Organizational Dynamics : The Polish Groups in Canada, Waterloo: Wilfrid Laurier University Press.

Rahmato, Dessalegn. 1984. Agrarian Reform in Ethiopia, Uppsala: Scandinavian Institute of African Studies.

Richardson, A. 1967. "A Theory and a Method for Psychological Study of Assimilation", International Migration Review, Vol. 2, No. 1. pp. 3-30.

Richmond, A. H. and Verma, R.P. 1978. "The Economic Adaptation of Immigrants, A New Theoretical Perspective", International Migration Review, Vol. 12, No. 1.

Rodney, W. 1972. How Europe Underdeveloped Africa, Dares Salaam: Tanzania Publishing House.

Rogge J. 1975. "The Qala en Nahala Resettlement Scheme", Sudan Notes and Records, No. 56, Khartoum.

-. 1981. "African Resettlement Strategies", International Migration Review, Vol. 15, Nos. 1-2, pp. 195-212.

Rose, P. 1981. "Some Thoughts about Refugees and the Descendants of Theseus", International Migration Review, Vol. 15, Nos. 1-2, pp. 8-15.

Rubenson, Sven (ed.). 1984. Proceedingsof the Seventh InternationalConference of Ethiopian Studies, Uppsala: Scandinavian Institute of African Studies.

Sandstrom, Allan. 1986. Mesqelblommans land. En bok om sviiltens och hoppets Etiopien. Uppsala: EFS Forlaget.

Scudder, T. and Colson, E. 1982: "From Welfare to Development: A conceptual Framework for the Analysis of Dislocated People" in Hansen, A. and Oliver-Smith, A., op. cit.

Shannon, Lyle and Magdaline. 1973. Minority Migrants in the Urban Community, Beverly Hills: Sage Publications.

Shils, E. 1978. "Roots. The Sense of Place and Past: The Cultural Gains and Losses of Migrants", in Human Migration Pattern and Policies, McNeil, W.H and Adams R.S. (eds.), Bloomington: Indiana University Press.

Skinner, E.P. 1965. "Labour Migration and its Relationship to Socio-Cultural Change in Mossi Society (1960)", Adapted by I.W. Wallerstein in Social Change: The Colonial Situation, New York: John Wiley and Sons, Inc. 
Spring, Anita. 1982. "Women and Men as Refugees: Differential Assimilation of Angolan Refugees in Zambia", in Involuntary Migration and Resettlement, Hansen, A. and OliverSmith, A. (eds.), op. cit.

Ståhl, Michael. 1974. Ethiopia: Political Contradictions in Agricultural Development, Stockholm: Rabén och Sjogren.

Stein, B.N. 1981. "The Refugee Experience: Defining the Parameter of a Field of Study", International Migration Review, Vol. 15, Nos, 1-2, pp. 320-330.

-. and Tomasi, S.M. 1981. "Forward", International Migration Review, Vol. 15, Nos. 1-2, pp. 5-7.

Steingraber, Sandra. 1987. "Resettlement and Villagizationin Southwest Ethiopia: A Report Based on Refugee Testimony Collected in Sudan, May-June 1987". AM Harbor: University of Michigan, Unpublished manuscript.

Stohl, M. and Lopez, G. (eds.). 1984. "Introduction" in The State As Terrorist: The Dynamics of Governmental Violence and Repression, London: Aldwych Press.

Stohl, M. 1984. "International Dimensions of State Terrorism", in Stohl, M., and Lopez, $\boldsymbol{G}$. (eds.) op.cit.

Stone. J. 1973. Colonist or Uitlander? A Study of the British Immigrant in South Africa, Oxford: Clarendon Press.

Stonequist, E. 1935. "The Problem of the Marginal Man", American Journal of Sociology, Vol. 41, No. 1, pp. 1-12.

Survival International. 1985. "Ethiopia - Resettlement: The Evidence", mimeo., London.

Taylor, R.C. 1969. "Migration and Motivation: The Case of Sub-Saharan Africa", in Migration, Jackson, J.A. (ed.), op.cit.

Teske, H. C., and Nelson, B.H. 1974. "Acculturation and Assimilation: A Clarification", American Ethnologist Vol. 1, No. 1, pp. 351-367.

Toennies, F. 1957. Community and Society, East Lansing: Michigan University.

Trimingham, John. 1976. Islam in Ethiopia, London.

Triulzi, Alessandro. 1980. "Social Protest and Rebellion in some Gäbbar Songs from Qellam Wälläga", in Modern Ethiopia: From the Accession of Menilek II to the Present, Tubiana, J. (ed.), Rotterdam: A.A. Balkema.

-. 1983. "Competing Views of National Identity in Ethiopia", in Nationalism and SelfDetermination in the Horn of Africa, Lewis, I.M. (ed.), op.cit.

Tubiana, J. 1983. "The Linguistic Approach to Self-Determination", in Lewis, I.M (ed.), op.cit.

Turner, Jonathan H. 1978. The Structure of Sociological Theory, Homewood, Illinois: The Dorsey Press.

Tuso, H. 1986. "The Oromos and the Conflictsin the Horn of Africa", Waldhaanso, Vol. 10., No. 2, pp. 4-47.

Tyhurst, L. 1951. "Displacement and Immigration: A Study in Social Psychiatry",American Journal of Psychiatry, No. 107, pp. 561-568.

United Nations 1982. International Migration Policies and Programmes: A World Survey, UN Department of International Economic and Social Affairs Population Studies, No. 80, New York.

- 1984. "Second International Conference on Assistance to Refugees in Africa: Detailed Description of Needs, Project Outlines and Background Information in the Refugee Situation. Report of the Secretary-General". Geneva, 9-11 July.

United Nations High Commissioner For Refugees. 1981. "Managing Rural Settlements for Refugees in Africa: Proceedings of a Workshop in the Follow-up to Arusha Recomendations on Rural Refugees in Africa", Dar es Salaam, September.

-. 1982a. Income-Generating Activities for Refugees in the Sudan. Report of the UNHCRIILO Inter-disciplinary Mission on the Employment, Income Generation and Training of Refugees in the Sudan. Geneva: ILO 
-. 1982b. "Survey of Hundred New Arrivals at the Gedaref UNHCR Sub Office Between 10 and 31 May 1982", Gedaref.

Vallely, Paul. 1986. "Land Blighted by Ideology", The Times, October 30.

van den Berghe, P. 1975. Man in Society: A Biosocial View, Amsterdam: Elsevier.

Waldron, Sidney. 1983. "Some Refugee Background Characteristics: Preliminary Results From the Qoriooley Camps", Northeast African Studies, Vol. 4, No. 3, pp. 17-24.

Wallerstein, I.W. 1965. Social Change: The Colonial Situation, New York: John Wiley and Sons, Inc.

Waugh, Evelyn. 1936. Waugh in Abyssinia, London: Longmans.

Weaver, J.L. 1985. "Sojourners Along the Nile: Ethiopian Refugees in Khartoum", The Journal of Modern African Studies", Vol. 23, No. 1, pp. 147-156.

—. and Kontos, J.F. 1982. "Refugee Situation in Sudan", Refugee Affairs Office, USAID, Khartoum, Unpublished Manuscript.

Weinberg, Abraham A. 1961: Migration and Belonging: A Study of Mental Health and Personal Adjustment in Israel, The Hague: Martinus Nijhoff.

Weiss, R. (ed.). 1973. Loneliness: The Experience of Emotional and Social Isolation, Cambridge, Mass.

Williams, R.C. 1972. Culture in Exile, Ithaca: Cornell University Press.

Wood, A. 1983. "Rural Development and National Integration in Ethiopia, African Affairs, Vol. 82, No. 329, pp. 509-539.

Zewde, B. 1984. "The Fumbling Debut of British Capital", in Rubenson, S. (ed.) op.cit.

Zolberg, A. and Suhrke, A. 1984. "Social Conflict and Refugees in the Third World: The Cases of Ethiopia and Afghanistan", Paper Presented at the Center for Migration and Population Studies, Harvard University, 22 March.

Zwingmann, Charles. 1973. "The Nostalgic Phenomenon and its Exploitation", in Uprooting and After, Zwingmann C, and Pfister-Ammende, M. (eds.), Berlin/Heidelberg: Springer-Verlag.

\section{Newspapers and Periodicals}

Addis Zemen, Amharic Daily, Ministry of Informations, Addis Ababa.

Ethiopian Herald, English Daily, Ministry of Information, Addis Ababa.

Horn of Africa, Horn of Africa Journal, New York.

Oromia Speaks, An OLF Publication, Khartoum and London.

Refugees, UNHCR Publication, Geneva.

Qay Faana, A COPWE Publication, Addis Ababa.

Voice of the Masses, A MEISON Publication. 


\section{Interview Questionnaire}

Respondent no. Settlement site

RESPONDENT AND HIS/HER HOUSEHOLD.

Ethnicity/ Nationality
1. Oron
2. Anhara
3. Tigray
4. Eritrean
5. Other

1. Male 2. Fenale

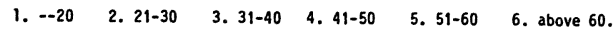
Marital status

1. single 2. married 3. separated/ divorced 4. widow

5. husband/ wife missing 6. other/ specify.

Total number of persons in the household
1. children
2. wives
3. other dependants

Do you share the house/ tukul with another family/ individual

not related to you by blood?

1. yes 2. no

If yes, who

$\begin{array}{ll}\text { 1. a refugee family from my country } & \text { 2. a fellow countryman (woman) }\end{array}$

3. a local (Sudanese) family 4, a Sudanese (individual) 5. other.

Before you left your homeland; how many persons were you in your

family/ household?

1. I was living alone 2. persons.

What happened to those. who are not here now?

1. still living back at home 2. have fled to another country

3. live elsewhere in Sudan 4. killed by the military

How are they related to you?

$\begin{array}{llll}\text { 1. parents 2. grandparents 3. child/ children 4. spouse } & \text { 3. }\end{array}$

5. sisters, brothers 6. others/ specify.

Number of generations in the present household.

1. single/ married couple without children, etc.

2. parent/s and children 3. household with grandparents.

Age of children in the household: give age and number.

1. 5 yrs or below 2. between $6-10 \mathrm{yrs}$

3. between $11-16$ yrs

Did you lose a member of your household due to death since your arrival in Sudan?

1. yes 2. no

If yes, what was the age of the deceased?

1. 1 year or below 2. 1 - 5 years 3. $6-15$ years

4. 16 - 30 years 5. above 30 years.

What was the cause of death?

Did you a member of your family leave the nousehold since you settled here?

1. yes 2. no

If yes, where did he/ she go?

1. settled elsewhere in Sudan 2. migrated to another country

3. went back home 4. to the field to fight 5. I do not know

6. no answer.

HOUSING CONDITIONS.

Type of house

1. tukul (hut) 2. tin shack 3. mad house with corrugated iron roof 4. other/specify.

Sufficiency of housing space for household members: How do you rat vis-a-vis pre-flight standards?

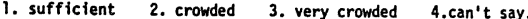

Do you/ your family/ own the house?

1. yes 2. rent it 3. other/specify.

If you rent the house, how wuch do you pay per month? is

- From where do you get water?

1. pipe 2. river/ spring 3. well, pond 4. other/ specify. b. Does the source function the whole year?

1. yes 2. no

c. Distance of water source from house.

1. kms 2. hrs on foot.

22. Does the household have latrine?

1. yes 2. no 3. share with other household/s

C. CAUSE OF FLIGHT FROM COUNTRY OF ORIGIN.

23a. Anticipatory: flight caused by what the respondent thought would happen to him/ her.

$\begin{array}{ll}\text { 1. fear of persecution for political reasons } & \text { 2. fear of religious }\end{array}$

persecution 3. fear of air raids and war 4. other/ specify

b. Acute flight: flight caused by what has actually happened to respondent. members of his/ her household, the household's property, etc.

1. actual political persecution (respondent or member of his/ her household was in prison; the police were after lifiti iner or menter of household, etc.) 2. actual religious persecution (persecuted for his/ her religious beliefs, prevented from exercising religious bel iefs, etc.) $3 . \quad$ air raid or war in the respondent's hometown or village 4. destruction of house, farm or other means of respondent's livelihood by war and air raids 5. other actual cause/ specify.

c. Flight due to respondent's opposition to or inability to meet, regime's policy/ proclamations.

1. heavy taxation 2. conscription into the militia/ military by force 3. forced labour 4. other/ specify.

d. Acute economic need.

1. famine caused by natural catastrophe 2. poverty and famine caused

by war in general 3. other/ specify.

24. Voluntary migration.

1. in search of job 2. in search of education 3. other/ specify.

25. Was your flight planned?

$\begin{array}{ll}\text { 1. Yes, plans and preparation beforehana } & \text { 2. no, it was sudden but not }\end{array}$ in panic 3. was in haste and panic.

26. Did you get information about the life of refugees in Sudan before you left your country?

1. yes 2. no

27. If yes, what was the information?

1. positive (information was that refugee life in Sudan is not difficult)

2. negative (refugee life difficult) 3. other/ specify.

28. What was the source of information?

1. mass media 2. traders 3. relatives/ friends who were or live in Sudan 4. no answer 5, other/ specify.

29. Did you find life in Sudan as you expected it ?

1. yes, it is as I expected $f t /$ heard about 2. no, it is better than what I expected 3. no, it is not as easy as I thought/ told 4. no answer.

30. Means of transport to Sudan.

1. on foot 2. by car 3. animal transport. 4. other/ specify.

31. Length of time the journey took in days.

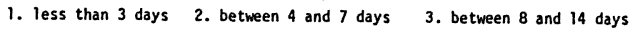

4. between 15 and 21 days 5 . between 22 and 28 days 6 . more than 28 days.

32. What were the hazards (dangers) you encountered on your way to Sudan?

1. no hazards. faced 2. attacked by military or border police

3. wild animals 4. robbers (shiftas) 5. other/ specify.

33. Other problems?

1. no problem on the way 2. lack of food 3. lack of water

4. malaria 5. other infectious diseases 6. other/ specify

34. Did any in your family or among the people you fled with die on the way to Sudan?

1. yes 2. no

35. If yes, how many people?

1. child/ ren adult/s 
36. That is the approximate age of the deceased person/s?

$\begin{array}{llll}\text { I. } 6 \text { years or below } & \text { 2. } 7^{-1}-16 \text { years } & \text { 3. } 17=25 \text { years }\end{array}$

4. 26 - 45 years 5. above 45 yearr.

37. Uhat was the cause of death7

I. ambushed by Ethiopian military 1 border police 2 lack of water

3. lack of food 4. malaria 5. other diseases 1 infections

6. exhaustion from long journey and bad weather conditions 7. do not know

8. others.

E IN SUDAR: ARRIYAL AND PROCESS OF SETTLGMENT IN HOST COUNIRY.

38. Date of arrival in Sudan (i.e., date of crossing border) 1. wonth year $19 \quad 2$ length of stay in Sudan months/years

39. Date of arrival on present site (settlement, town, village).

1. month year 19

40. On your arrival in Sudan, what was/ivere the most difficult problem/s encountered?

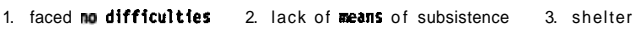

4. gett ing residence permit in Sudan 5 weather conditions

6. language problems 7. culture related problems 8. otherl specify

41 If answer for $Q 40$ is (culture-related): Which?

42. Did you solve the problena/s?

I - yes totally 2 yes partially 3 3. M 4 4. no answer.

43. If yes (has solved problem/s) who helped you to solve it 7

$\begin{array}{llll}\text { I - no one. but myself } 2 \text { relative/s } & 3 \text {. countrymen } & 4 \text {. the loca }\end{array}$ people (Sudanese) 5 Sudanese government authorities 6 . humanitarian organization/s 7. otherl specify

44. Number of tines respondent changed sites (place of residence) in Sudan I - not changed at all 2 changed one time 3 . changed two times 4. changed three times 5. changed more than three timer

45. Reason/s for changing sites.

1. to join relatives or family menbers 2 In search of job

3. in search of education 4 . in search of cultivable land

5 because of health reasons 6 . because the cuthorities told me to do so

7. other/specify.

46. How long do you intend to stay in the present place of residence?

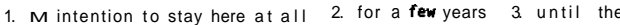
t ine when return to country of origin is possible 4. forever (do not intend to nove el sewhere) 5. depends on circupstances (if better opportunities are available elsewhere do not intend to $\mathbf{s t a y}$ ).

47. If respondent intends move to another place in Sudan or to another country ask: Why?

1. because of health pmblemr 2 to join fontly/ relatives

3. In search of education 4. in search of job 5. change climate

6. otherlspecify.

F. ECONOMC CONDITONS: OCCUPATION, EMPLOYMENT AND PROPERTY RELATIONS (OHMERSHIP) BOTH IN CONIRY OF ORIGIN AND IN HOST COUNTRY.

48. Did you take your property (possessions) with you when you left your country7 $\begin{array}{lll}\text { I. yes (all or most of it) } & \text { 2. yes (part of it) } & \text { 3. no (left everything }\end{array}$ behind) 4. I had no property.

49. If yes. what kind of possessions?

I- livestock 2 cash (money) 3. otherl specify.

50. If livestock. what and how many?

1. cattle head 2 sheep/goats $h$ e a d 3. canel head

4. otherlspecify $h$ e a d

51. What happened to these possessions you took with you when you left home? I - have kept all of it 2 have kept part of it 3.sold and exchanged a11 of it at the border 4. sold and exchanged part of it 5. I war robbed of all of it on the ray $L$. $I$ was robbed of part of $i t ~ 7$. other.

52. If left property behind. what? and how many?

1. livestock __ head of cattle, $\mathrm{s}$ h e e $\mathrm{p}$, goats. __ other

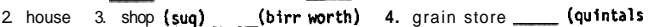
approx.) 5. otherlspecify.

53. What happened to this property you left behind7

1. do not know 2 confiscated by government 3 . being used by relatives

4. otherl specify.

54. Did you have an occupation in your hone country?

I - yes 2 no (I was unemployed) 3. housewife
55. If yes, were you:

1. self-employed? 2 civil servant (governaent employee)?

3. exployed by private person or company? 4. "other"

56. If self-employed, were you:

I- peasant farmer? 2 pastoral ist (nomad)? 3 . handcraftmn?

4. otherl specify.

57. If government employee what job did have?

1. clerk (all office work) 2 soldier1 policeman 3. driver 4. other specify.

58. If exployed by private person/ company were you:

1. agricultural rage-labourer 2.factory worker 3. donestic servant

4. Iriver 5. construction worker 6. otherl specify.

59. If "other" (see $56: 4$ above) what?

1. housewife 2 student 3.dependent (not of employment age)

4. pensioned S. otherl specify

60. If peasant farmer or agricultural worker. did you om land7

I. yes 2. no

61. Preser. I amloyment status.

I. exployed 2 unemployed 3. housewife.

62. If employed, by whom?

I. self-employed 2 . by the Sudanese state 3 . by a Sudanese private company/ businessman 4. by a fellow countryman (refusee)

5 . by a Sudanese family 6 . otherl specify.

63. What is your Occupation. i.e. vhat kind of job do you have at present?

W. What is your household incone (approximately). take last year for example is

65. How many menters of your househald are working and earning incoe current

66. Uhat is the approximate total monthly incame of your household including yours now? IS

67. Is your income sufficient to cover the cost of subsistence for you and yovr family? 1. Yes 2 no.

68. If no. how do you manage to live7

1. with assistance from $\mathrm{UNCR}$ and other humanitarian organization

2 with assistance from relatives 1 friends 3 . previous savings 4. otherl specify.

69. Ifrespondent is unemployed what is his/ her source of subsistence? Qs. 70 - 73b are for respondents in rural agricultural settlement.

70. How mach land is alloted to you ?

I - none 2 less than 10 feddans 3.10 feddans 4. more than 10 fedda

71. Is the produce from your alloted plot of land sufficient to cover your ne I. yes 2 no.

72 If no. how do you meet yovr subsistence needs?

73a. Does he/ she produce surplus for sale?

I. yes 2 no.

b. If yes, how much did you earn from surplus sale last year? I5

74. How many months in a year are you employed7

75. If employsent is not far the whale year. how does he/ she spend the time during unemployment?

I. roaming about 2 petty trade 3. looking for job 4. other/specif

76. What is the means of respondent's subsistence during the unemployment per 1. savings 2 aid from UN-DR or hunanitarían organizations 3 . loan 4. help fron relatives and friends 5 other/ specify.

77. Approximately what percentage of your income is spent on:

I - food 2 house rent 3 . medicine 4. school for children 5. farm implements 6. otherl specify.

78. Do you own property here in Sudan7

I - yes 2. no.

79. If yes. what? How much/ many?

80. If you compare your present economic situation with what you had in you home country. would you say you are: $\begin{array}{llll}1 \text {. poorer } & 2 \text {. same } & 3 \text {. better } 7\end{array}$

F: EDUCATIONAL BACKGROND OF RESPONDENT AND CHILREN IN SCHOOL.

81. Did you attend school in your home country?

82. Ifyes. what type of school?

83. Which level did you complete7

84. Are you following any educát tonal programe now?

I- yes 2 no.

85. If yes. what type/leveli

86. If then are children of school age in respondent's household are they attending school7 
Ifyes, what type of school?

If children do not go to school. ask why not?

THE PAOCESS OF ADJUSTMENT AND IMTEGRATION.

Do you speak hrabic?

1. ves 2. no

If yes, how much?

I. some Arabic 2. quite good Arabic 3. fluent Arabic

Can you read and write Arabic?

Where did you learn Arabic?

If the responsent does not speak Arabic, ask: are you trying to learn?

If no. Why not?

Do menbers of your household speak Arabic?

1. yes, all of them speak it 2. only one of then 3. sose of them speak ,

4. none of them.

Do you have health problems?

1. yes $2 \mathrm{M}$

If yes. what?

Did you have such $m$ illness prior to your flight to Sudan?

I. yes 2. no.

Have you been to a doctor for treatment?

I. yes 2. no

If no, Why not

\section{PROBLEMS OF ADJUSTMERT a CAUSES OF ANXIETY.}

Is there anything that is making your adjustment in the Sudan still difficult?

I. yes $2 \mathrm{M}$.

If yes, What?

b. What are the changes. if any. you made In your life-style (habits customs, beliefs, etc.) since you came to Sudan?

c. Why did you make the change?

Do you consider yourself as

I. temporary refugee (gradually will and can return home)

2 permanent refugee (no hope of going back home).

Would you become a Sudanese cftizen If you were given the chance

Do you ever fear or think that something very bad could happen to you

because you are a refugee?

If yes, h a t for example do you think could happen to you?

Do you feel guilty because you left behind menbers of your fanily,

relatives, etc. when you fled?

Are you anxious (afraid) that something very bad could happen or

lias already happened to the. because of your flight7

If yes. What?

\section{SOCIAL RELATIONS, MEMBERSHIP IN ASSOCIATION AND ORGANIZATIONS.}

Do you belong to an sssociation/ organization where refugees are the only mers?

If yes, that type of association/ organization?

I- cultural 2 religious 3 . economic 4. political S otherl specify.

Were you a member of such an organization before you came to Sudan7

How does this association/ orgnaization benefit you now?

\section{RELATIONS BETWEEN REPUGEES AND THE LOCAL POPULATION.}

Are there associations in your neighbourhood which recruit members from both the refugees and the local population?

Ifyes. What are the functions of such an association? How do the nembers make use of it 7 How does it benefit thea?

Are you a member of such an association?

Do you have infortal contacts (outside of the place) with the loca population7

If yes, how and where do your contacts take place?

1. Often fnvited to Sudanese homes and I also Invite them to my house
2. I often invited to Sudanese feasts and hol 1day celebrations

3. other/specify.

119. Do you or someone in your fantly have marriage relations with a loca fantly or fanll les?

I- yes 2 no

120. Is intermarriage common between refugees and Sudanese In your locality?

121. If no intermarriage, What is the reason?

122. Are there open conflicts between the rafugees and the local population? I. yes. almost always 2. yes. often 3. only occasionally 4. no conflicts.

123. What are the nature of these conflicts? In which forms do they occur7 I - verbal fights 2. fist fights 3. fights with weapons 4. other/specify.

124. How many people do such conflicts usually involve I - only two people 2 often more than two people 3. sometines groups on each side 4. other/specify.

125. What do you think are the cause of these conflicts7

1. cultural differences 2 religious differences 3 . economic factors

(e.g, the local people blame the shortage of cormodities, high prices etc.

on the influx of refugees) 4. other/spectfy $S$. do not know.

$\begin{array}{lll}\text { 1. yes, they are increasing } & 2 \text {. no, they are decreasing } & 3 \text {. it has }\end{array}$ always been the sare 4, other/specify. S. do not know.

127. How a $m$ the conflicts resolved (settled)?

1. Intervention frm the police 2 intervention from the army

3. in court 4. mediators (elders) S. otherl specify.

128. Are there conflicts between the refugees themselves?

I- yes 2. no

129. What are the causes?

1. ethnic differences 2. rellglous differences 3. political differences

4. other/ speclfy. 5. don't know.

130. Do these conflicts af fect you directly?

I- yes 2. no

131. If yes. Which type?

1. conflict between refugees and Sudanese 2 conflict among the refugees thenselves 3 . both type of confiticts

132. How do they affect you 7

I- affect my security 2 affect my property 3 . affect me psychologically 4: other/ specify.

If the respondent liver in a state organized sett]ment, ask him/ her

Qr 133-142. Otherwise go to $Q 143$

133. Do these conflicts affect the settlement7

I - yes 2. no

134. If yes. Which of the conflicts 7

1. conflict between the local people and refugees 2. conflict among the refugees 3. both type.

135. How do they affect the settlement?

1. cause material damage 2 create sense of insecurity among settlers

3. other/specify.

ง. REFIIGEE ATTITUDE ABOUT ORGANIZED SETTLEMENT.

136. How do you consider this settlement as a place to live ?

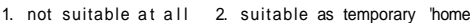

3. sut table as pemnent 'home'.

137. If 'unsuitable. why?

138. Uhat do you think should be done to improve the situation in this settlement?

139. How are decisions affecting this settlement and its inhabitants made?

i.e.. are the refugees involved or consulted?

1. yes, always 2 sometines 3 . not at all.

140. If refugees participate in decision-making at what stage?

1. When the settlemnt rite is selected 2 planning and implementation of settlemnt activities - like building schools, clinics mosoues, etc. 3 administration of settlement site 4. otherl specify.

141. How did you cone to this settlement?

I own choice 2. have had no al ternative and took the opportunity

3. was brought here by authorities 4. arrived here.directly

S. other/ specify.

142. If the situation in the settlenent is improved, $\mathbf{f}, \mathrm{e}_{+}$, if employment, land, social services and facilities are node available. and security is granted. would you consider staying here far a long tine? 


\section{K. POLITICAL AHAREMESS ARD PARTICIPATIOH.}

343. Before you left your country, were you politically aware7 ie. were you dissatisfied with the Ethiopian regime, did you want some sort of political change?

1. yes 2. no

144. If yes, were you involved In some form of opposition?

1. yes 2 no

145. If yes, how were you Involved?

1. was member of a student union 2. was member of a liberation front

3. supported a liberation $\mathrm{fmnt}$ 4. Other/ specify.

146. Are you still as active or as Involved as before?

147. (If response Is'less active' or "not Involved") why7

148. If answer to $Q 143$ is "no" ark: have you becone politically aware ont consclous during your stay in Sudan?

1. yes 2. no

149. Are you involved in political activities at present7

1. yes 2. no
150. (If respondent is involved in polftical activitles presently) Haw arc you involved7

L VOLUNTARY REPATRIATION: REFUGEE OPINIONS ABOUT RETURNING HONE,

151. Uhat do you think wold be a permanent solution to the problem of refugees from your country?

1. permanent settlement in Sudan or other host countries 2 voluntary repetriation.

152. Under what circumstances would you be prepared to return to your hothe country?

153. Do you get enough infornation about your home country and the situation 1. yes 2. no

154. What kind of assistance do you think you would need In order to start life again when you return home? 
Today, about half of the refugees in the world are Africans. More than half of Africa's refugees originate from Ethiopia and live in the Sudan and Somalia. As a source of refugees, Ethiopia is surpassed only by Afghanistan. This book is about this mass exodus from Ethiopia.

The author maintains that in the absence of a clear understandingof its root causes it is impossible to find lasting solutions to this problem of mass displacement. Therefore, he employs an historical approach and commences the study with an investigation of the links between the past history of the peoples of the Horn of Africa and the conflict which currently plague the region.

Much of the study is concerned with the problems faced by the uprooted and is based on information obtained through interviews with several hundred refugee households living in the Sudan. The author traces their experiences at the various stages of their flight. He thoroughly examines the subjective and objective conditions which forced these people to make the painful decision to leave their homes and seek free haven in alien environments. He lays bare the interconnection, in Ethiopia, between state terrorism, state policies and programmes, and mass displacement.

Much space in the book is given to the problem of integration in the host environment. The author explores the refugees' struggles to eke out their subsistence in a country with severe economic problems, their relations to their hosts and their anxieties as aliens in a foreign land. He compares the viability of the various settlementstrategieswith regard to the achievement of economicself-sufficiencyand socio-cultural integration.

The author attempts to overcome the lack of theory in refugeestudies by developing methodological approaches and typologies, adapting conceptsfrom other fields and applying them to the study of forced migration. The book is written for academicians, policy makers, those engaged in humanitarian work and above all those concerned with the problems of the Horn of Africa.

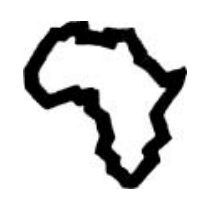

Published by:

Scandinavian Institute of African Studies

P O Box 1703, S-75147 Uppsala, Sweden

Distributed by:

Almqvist \& Wiksell International

P O Box 638, S-101 28 Stockholm, Sweden 